\title{
PLURILINGUAL CLASSROOM PRACTICES AND PARTICIPATION
}

\section{ANALYSING INTERACTION IN LOCAL AND TRANSLOCAL SETTINGS}

\author{
Edited by
}

Dolors Masats and Luci Nussbaum

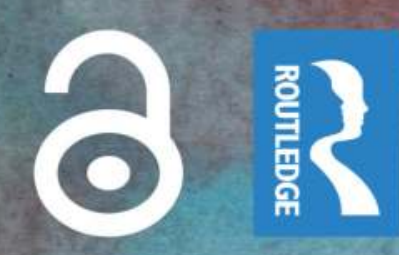




\section{Plurilingual Classroom Practices and Participation}

Plurilingual Classroom Practices and Participation contributes to a better understanding of plurilingual education in Catalonia by providing a description of the interactional resources mobilised by learners as social actors.

This volume is a collection of studies that show interactions containing plurilingual and multimodal sequences that illustrate moments of potential acquisition of aspects of language use. Analysing data collected through ethnographic fieldwork, the studies explore interactions in primary, secondary and tertiary milieus as well as non-formal settings and examine how participants organise their interaction, their ways of participating, and the resources they mobilise for them.The linguistic policies of the educational settings studied establish the use of a given language but contain samples of plurilingual practices in which languages like Arabic, Catalan, English, French, Greek, Mandarin, Punjabi, Riffian Berber Spanish and Urdu come into play. The chapters explore the links between these practices and the construction of participation in the ongoing interaction.

Although focused on language education in Catalonia, results can be transferred to classrooms worldwide that host plurilingual learners. Thus, the volume is an excellent resource for teachers and researchers interested in plurilingual education and can be used as a reference book in doctoral studies and teacher training programmes in this research field.

Dolors Masats is a senior lecturer and researcher at Universitat Autònoma de Barcelona. She has led various research projects at national level and published widely in the field of conversational analysis applied to language learning in multilingual and multicultural settings, including language awareness, taskbased and project-based teaching and learning, technology-enhanced learning, video production and education for indigenous peoples.

Luci Nussbaum is an honorary professor at Universitat Autònoma de Barcelona, where she founded the Research Centre for Plurilingual Education \& Interaction (GREIP). She has specialised in the study of oral interaction in multilingual language learning milieus from the perspectives of interactional sociolinguistics and conversational analysis and has led and participated in numerous research projects and research networks both at national and international level. 


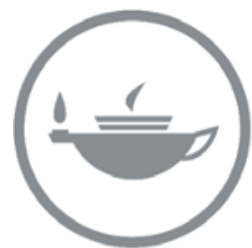

Taylor \& Francis Taylor \& Francis Group http://taylorandfrancis.com 


\section{Plurilingual Classroom Practices and Participation}

\section{Analysing Interaction in Local and Translocal Settings}

Edited by Dolors Masats and Luci Nussbaum

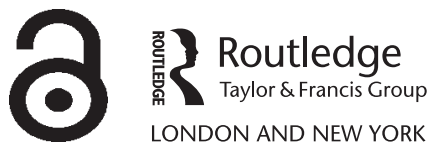


First published 2022

by Routledge

2 Park Square, Milton Park, Abingdon, Oxon OXI4 4RN

and by Routledge

605 Third Avenue, New York, NY 10158

Routledge is an imprint of the Taylor \& Francis Group, an informa business

(C) 2022 selection and editorial matter, Dolors Masats and Luci Nussbaum; individual chapters, the contributors

The right of Dolors Masats and Luci Nussbaum to be identified as the authors of the editorial material, and of the authors for their individual chapters, has been asserted in accordance with sections 77 and 78 of the Copyright, Designs and Patents Act 1988.

The Open Access version of this book, available at www.taylorfrancis.com, has been made available under a Creative Commons Attribution-Non Commercial-No Derivatives 4.0 license.

Trademark notice: Product or corporate names may be trademarks or registered trademarks, and are used only for identification and explanation without intent to infringe.

British Library Cataloguing-in-Publication Data

A catalogue record for this book is available from the British Library

Library of Congress Cataloging-in-Publication Data

A catalog record has been requested for this book

ISBN: 978-0-367-76958-I (hbk)

ISBN: 978-0-367-76960-4 (pbk)

ISBN: 978-I-003-169|2-3 (ebk)

DOI: $10.4324 / 9781003169 \mid 23$

Typeset in Bembo

by Newgen Publishing UK 
This volume is dedicated to all teachers, educators and learners, who have welcomed us into their classrooms and learning spaces throughout the past 25 years. 


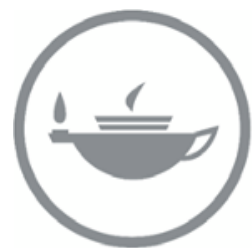

Taylor \& Francis Taylor \& Francis Group http://taylorandfrancis.com 


\section{Contents}

List of contributors

Introduction: Plurilingual classroom practices and participation

DOLORS MASATS AND LUCI NUSSBAUM

\section{PART I}

Teachers promoting plurilingual practices

1 Going out on a limb? Introducing a plurilingual perspective in a university business English subject JOSEP M. COTS

2 Plurilingual modes of interaction in English-medium university classes

EULÀLIA BORRÀS AND LUCI NUSSBAUM

3 Creating a plurilingual space through talk-in-interaction DOLORS MASATS AND ARTUR NOGUEROL

\section{PART II}

\section{Students as plurilingual teachers}

4 Plurilingual practices and pluriliteracies in an after-school program: Encouraging children's use of their entire repertoire for meaning making CLAUDia VALLEjo

5 Students as teachers, teacher as learner: Collaborative plurilingual teaching and learning in interaction 
6 Showing attention: student's turn co-construction and other-initiated other-repair

LUCI NUSSBAUM

\section{PART III}

Students as plurilingual sociolinguists

7 Building the sociolinguistic environment through

talk-in-interaction

VIRGINIA UNAMUNO

8 Doing 'being sociolinguists': Students' envisagement of languages, varieties and uses

\section{PART IV}

Plurilingual and multimodal activities in knowledge construction

9 Plurilingual teamwork practices in an internationalised setting at a Catalan university

EULÀLIA BORRÀs

10 Multimodality in English medium higher education JOAN PLOETTNER

11 "How do the apples reproduce?" Mediation-in-interaction in a university CLIL course

EMILEE MOORE

\section{PART V}

Plurilingual activities in computer-mediated interaction

12 “Can you repeat please?”Young learners' emergent awareness and use of interactional repertoires in a telecollaborative exchange MELINDA DOOLY

13 "What do you like about Spain?": Building understandings of people and places in interaction mediated by plurilingual and digital resources 


\section{PART VI}

Plurilingualism in student's international encounters

14 Professional language in automotive maintenance training:Translocal intercomprehension between students from Barcelona and Lyon VÍCTOR CORONA

15 Interactional competence in transnational plurilingual peer interactions CÈLIA PRATGINESTÓS

16 "Let's talk about el catalan's $=0$ )": Student teachers' use of plurilingual and plurimodal resources in WhatsApp interaction MELINDA DOOLY AND ANNA CZURA

Index 


\section{Contributors}

Except in those cases specified otherwise, all contributors to this volume are active members of the Research Centre for Plurilingual Education \& Interaction (GREIP, 2017-SGR-0774), sited at Universitat Autònoma de Barcelona.

Eulàlia Borràs is an associate professor in the Department of English and Linguistics at Universitat de Lleida. Her research explores multilingual classroom management and relations between university language policies and language use. She is also interested in working in multilingual groups, inside and outside the classroom, as well as on the management of multimodality.

Víctor Corona is an associate lecturer at Universitat Autònoma de Barcelona and member of GREIP. He is also an assistant professor at Université de Paris VIII and collaborates with the research group SFL (Structures Formelles du Langage, CNRS). His research interest is related to linguistic ethnography in educational contexts, linguistics of the interaction, linguistic stylisations, contact of languages and the construction of identity.

Josep M. Cots is Professor of English and Applied Linguistics in the Faculty of Arts of the University of Lleida and member of the research group Cercle de Lingüística Aplicada (CLA). His research focuses on applied discourse analysis, foreign language teaching and learning, multilingualism, and intercultural competence, especially in the context of specific language policies in secondary and tertiary education.

Anna Czura is a post-doctoral researcher and a Marie Curie fellow (MSCA IF) at the Department of Language, Literature, Education and Social Science of the Autonomous University of Barcelona. Her research and teaching interests centre on teachers' beliefs and practices, language assessment, intercultural competence, learning mobility (both face to face and virtual), Content and Language Integrated Learning and European language policy.

Melinda Dooly is a full professor at Universitat Autònoma de Barcelona, where she holds a Chair in Technology-mediated Language Teaching and Intercultural Education. She is also the principal investigator of the GREIP. 
Her research interests include technology-enhanced project-based language teaching and learning, category constructions of linguistic diversity and social inequalities in education policies.

Júlia Llompart is an adjunct professor at Universitat Autònoma de Barcelona and research assistant for the GREIP. Her research focuses on plurilingualism and inter- and intragenerational language transmission.

Dolors Masats is a senior lecturer and researcher at Universitat Autònoma de Barcelona. Her research interests revolve around the study of the Conversation Analysis applied to language learning and in the design, implementation and assessment of curricular and classroom proposals, structured around multilingual and multidisciplinary projects.

Emilee Moore is an associate professor at the Universitat Autònoma de Barcelona. Her research is framed within the study of linguistic practices in multilingual and multicultural educational contexts from a perspective that integrates linguistic anthropology, interactional sociolinguistics and sociocultural learning theories.

Artur Noguerol is an honorary professor from the Department of Language Teaching Methodology at Universitat Autònoma de Barcelona. He coauthors the framework of reference for pluralistic approaches to languages and cultures (FREPA) and conducts his research in the area of language and cultural diversity and plurilingual education.

Luci Nussbaum is an honorary professor from the Department of Language Teaching Methodology at Universitat Autònoma de Barcelona. Her research focuses on the study of oral interaction in multilingual language learning milieus from the perspectives of interactional sociolinguistics and conversational analysis.

Joan Ploettner uses interactional analysis to study English Mediated Instruction (EMI) teacher development processes and EMI teaching expertise. She also focuses on learning opportunities in student generation of assessment criteria for writing in Integrated Content and Language Learning in Higher Education (ICLHE).

Cèlia Pratginestós is an associate lecturer at Universitat Autònoma de Barcelona and at EUNCET Business School. Her research focuses on the study of Conversation Analysis applied to language learning and the deployment of interactive competence in plurilingual peer interactions.

Virginia Unamuno is an independent CONICET researcher at the Centre for Language Studies in Societyof the Universidad Nacional de San Martín. Her research interests revolve around the study of language policies from ethnographic and interactional perspectives. She also studies the new uses 
and meanings in the transmission of indigenous languages in northern Argentina.

Claudia Vallejo is an associate lecturer at Universitat Autònoma de Barcelona and research assistant for the GREIP. Her research focuses on the role of cultural and linguistic diversity in the academic trajectories of students from cultural and linguistic minorities, especially those considered at risk of school failure. 


\title{
Plurilingual classroom practices and participation
}

\author{
Dolors Masats and Luci Nussbaum
}

\section{Introduction}

Historical political and demographic circumstances have shaped Catalonia as a multilingual region in which the three co-official languages, namely Aranese, Catalan and Spanish, co-exist with a wide variety of other world languages. The most recent change in the sociolinguistic landscape of Catalonia occurred at the turn of the century, with the arrival of an important contingent of people from all parts of the world. Currently, more than $15 \%$ of the total Catalan population is of foreign origin (Idescat, 2020), which means it is easy to observe everyday interactions being conducted in a variety of languages - the inhabitants of Catalonia use Aranese, Catalan, Spanish or any other non-co-official language to communicate with one another according to their linguistic biographies.

The Spanish Constitution (Constitución Española, 1978) establishes that Spanish is the official state language, and declares other languages co-official with Spanish in their corresponding territories. The Catalan Statute of Autonomy (Estatut d'Autonomia, 1979 [2006]) confers 'co-official' status to Aranese, Catalan and Spanish, but defines Catalan as Catalonia's 'own language' and grants its 'normal' use in most aspects of life, including public institutions such as schools and universities. The fact that Catalan is the vehicular language at schools (as is Aranese in Val d'Aran, in north-western Catalonia) guarantees that it is used both for teaching most of the curricular contents and as the medium of communication between school boards and the community (including families). Spanish and one or two foreign languages are also taught as subjects or as a medium of instruction of other curricular subjects. Language policies in Catalonia establish that at the end of compulsory education (6-16 years), all students must have acquired a B2 level in Catalan and Spanish, a B1 in the first European foreign language, and an A2 level in a second European foreign language or a heritage language (see Departament d'Ensenyament, 2018). These official requirements must be implemented by schools and specified in their so-called School Language Project (Projecte Lingüístic de Centre), a document outlining the actions concerning language education taken in by each school board (see Masats and Noguerol, 2016). 
Catalan is also the preferred language at university level, although teaching can be done in Spanish. In response to internationalisation, language policies establish that universities can provide specific measures for including other languages in teaching and administrative communication. In this regard, English has gained a substantial presence in teaching content subjects, not only for allowing local students to acquire functional and professional competences in this language, but also to attract foreign students and researchers (see Moore and Nussbaum, 2014; and, in this volume, Cots, Borràs, Borràs and Nussbaum, Moore).

The study of plurilingual education in Catalonia in primary, secondary and tertiary educational stages as well as non-formal education is the common interest shared by of all the authors of this volume. We are all (or have been) members of the Research Centre for Plurilingual Education \& Interaction (GREIP), whose mission statement is to understand the impact that plurilingual competence, pluriliteracies and plurilingual discourse in everyday interaction have on formal and non-formal educational settings. Following the Common European Framework of Reference for languages (CEFR, Council of Europe, 2001), in this book we use the term 'multilingualism' to refer to the social or institutional presence of two or more languages in a territory or community, whereas the term 'plurilingualism' refers to uses of communicative resources belonging to various semiotic systems. Moreover, 'plurilingual' practices evoke the everyday uses of people in multilingual settings.

In the following section we present the research approaches for the study of plurilingualism adopted in all the contributions to this volume. It relies on the employment of ethnographic procedures to collect data and on the study of talk-in-interaction to document and analyse language practices and learning traces. Second, we discuss some insights regarding plurilingual practices in educational settings and the main theoretical postulations that inspire our analysis. Finally, we describe the organisation of the book.

\section{Doing field work}

Over the years our research has been and is guided by two objectives. First of all, we want to build didactic knowledge about teaching and learning languages and other curricular contents from a holistic perspective anchored in educational realities and based on the study of natural data. Secondly, we wish to work in cooperation with teachers and educators to establish synergetic relationships with them. We think that research can contribute to empowering teachers and other educational practitioners and that the latter can ensure research remains rooted on the ground. To attain this dual purpose, in many studies represented in this volume we have designed and implemented projectbased learning sequences (Nussbaum, 2017; Dooly and Masats, 2019) or other educational proposals in joint collaboration with teachers and educators, and 
together we have also analysed learning processes and products as an articulated whole. Occasionally, the development of these collaborative projects was also done with the cooperation of trainee teachers and graduate students (Masats and Guerrero, 2018). Sometimes researchers have also performed as teachers.

The adoption of this programme, which we refer to as collaborative action research (Nussbaum, 2017; Masats et al, 2021), turned us into privileged participant-observers, since we could access educational establishments not only as researchers (or advisers), but also as accountable agents who, in collaboration with teachers and other educators, engaged in action research processes, to improve teaching and learning practices. The action-research cycle, in its various phases, has allowed us access to policy documents of each institution, teachers' work plans, and, above all, the interactional practices in classrooms and other learning spaces, collected through audio and video recordings. These data constitute, in a certain way, 'boundary objects' (Star and Griesemer, 1989; Moore, Ploettner, and Deal, 2015; Moore and Tavares, 2020), that is, artefacts that have different meanings depending on the setting, but that allow exchanging views between different agents (in our case, the research team and the teaching/educator team). These boundary objects allow teachers/educators and researchers to reflect on the educational activities at hand, on their behaviour in the classroom and other learning spaces, and on the learning difficulties students encounter. For the research team, these objects also constitute firstorder data to analyse plurilingual practices in environments of significant language diversity, which is our ultimate goal.

Our habitual presence in educational settings and our participation in the projects we have helped develop and monitor have let us to become, at least for a period of time, members of the educational community, carry out ethnographic work along the way and gain deep knowledge of educational policies and usual linguistic practices. In turn, this has raised our understanding of certain aspects related to leaners' language socialisation practices (Duranti, Ochs, and Schieffelin, 2011), particularly those of children of migrant origin (Nussbaum and Unamuno, 2006) in the context of Catalan schools. We are aware that Conversational Analysis and Ethnomethodology - fields that inspire most of the exploration of our data - have a strict vision of the notion of context (see Moore and Vallejo, this volume). However, as Kunitz and Markee (2017) indicate, when institutional talk is analysed, people who do not belong to the institution need certain information to understand its ins and outs and find answers to the observable phenomenon. For example, if, as mentioned earlier, Catalan is the vehicular language of schools, we wonder why teachers sometimes speak Spanish with her students, or why many students communicate through Spanish either in the playground or in the classrooms. Ethnographic observation gives us clues to understand languages use preferences. Additionally, participant observation in institutional spaces allows to witness the enactment of what Bonacina-Pugh (2012) refer to as "practiced language policies". 


\section{Interactionist perspectives to analyse plurilingual practices in educational settings}

In this section, we will consider three key constructs that have guided our research on language education in formal and non-formal settings, although authors in each chapter will present their own approach. First, we will refer to the notion of plurilingual and pluricultural competence. Second, we will explore how the concept of participation relates to plurilingual practices and to the findings of other studies that analyse data from a socio-interactional perspective, as is the case in this volume. Finally, we will take into consideration key aspects for the analysis of plurilingual interactions, such as language choices or alternations at moments during the interaction.

\section{The notion of plurilingual and pluricultural competence}

The notion of plurilingual competence stems from the concept of communicative competence developed by Hymes $(1972,1973)$ and further discussed and expanded by many other authors. Coste, Moore, and Zarate (1997) define plurilingual and pluricultural competence as speakers' ability to employ different languages, linguistic varieties and forms of communication to participate in intercultural interactions. As Coste, de Pietro, and Moore (2012) argue, the term plurilingual competence relates to a holistic view of speakers' communicative skills; acknowledges the existence of partial competences in various languages; recognises the existence of connections between the partial competences speakers have in the languages of their repertoires; presents a dynamic view that reshapes the abilities of plurilingual speakers; includes mediation capacities, and is constructed and reconfigured through the life trajectories of each individual (see also Nussbaum and Unamuno, 2006; Blommaert and Backus, 2011).

Consequently, plurilingual competence is not the sum of multiple monolingual competences; it is a capacity composed of a set of stabilised language forms in various languages, but also of new forms created in situ by participants to achieve practical purposes. It is unique (it differs from speaker to speaker), complex (made up of a repertoire composed of a variety of resources), unbalanced (speakers' language abilities may be different from one language to another) and evolving (it is malleable and constantly developing). From an interactivist perspective, it is not a strict personal ability, instead, it is developed through talkin-interaction and, therefore, it is contingent and not transferrable from one situation to another (Pekarek-Doehler, 2005). Above all, it is a socially-situated competence rooted in action, that is, its display depends on how speakers co-construct the communicative event they participate in. Plurilingual and pluricultural competence is part of a wider communicative capacity that allows speakers to use language as a whole, according to the circumstances; therefore, it involves all the aspects of talk-in-interaction such as gesture, laughter 
and other expressive resources, lexical, phonetic and grammatical forms, but also semantic, sociolinguistic and pragmatic dimensions of interactional competence (Hall, Hellerman, and Pekarek-Doehler, 2011; see also Dooly, this volume; Pratginestós, this volume).

\section{Participation and learning}

The notion of participation has been widely studied and discussed in the language sciences (see Mondada and Nussbaum, 2012). In this book we focus on how it shapes learning in plurilingual milieus and take into account its multimodal dimension. Mainstream researchers on second language acquisition have typically conducted longitudinal, experimental laboratory studies to investigate how learners acquire and learn linguistic forms or other components of their interactional competence. In contrast, studies developed from a sociocultural perspective, like the ones in this volume, are rooted in the principle that learning only takes place through social interaction. Sociocultural perspectives are multidisciplinary in nature and may include a wide variety of approaches, among which we could cite Sociocultural Theory (Lantolf and Thorne, 2006; Thorne and Hellermann, 2015), the Theory of Language Socialization (Duranti, Ochs and Schieffelin, 2011), the Theory of Situated Learning (Lave and Wenger, 1991; Wenger, 1998), Language Socialisation across learning spaces (Sook Lee and Bucholtz, 2015), the Strong Socio-interactionist Perspective (Mondada and Pekarek-Doehler, 2004; Pekarek-Doehler, 2013), and CA-for-SLA studies (Markee and Kasper, 2004; Kasper and Wagner, 2011). Researchers in all these fields share the view that learning takes place through interaction and not only in the speakers' minds, which means supporting the view that cognition is socially situated and distributed (Mondada and Pekarek Doehler, 2004).

As Llompart and Nussbaum (2018) suggest, the various sociocultural perspectives cited above, grouped under the umbrella 'socio-interactionist', consider that the evolution of forms in which learners participate in situated activities constitute evidence of learning (see Pekarek-Doehler and Fasel Lauzon, 2015; Borràs, this volume; Moore, this volume). As a consequence, to understand how learning occurs it is necessary to trace the evolution of learners' interactional practices, instead of exclusively looking into the modifications occurring in their repertoires (Young, 2008; Hall, Hellermann, and PekarekDoehler, 2011, among others). From this perspective, plurilingual practices play a key role as, in order to participate in talk-in-interaction, learners need to activate their full repertoire (see next section). In this sense, studies on pairwork interaction in educational settings (see Masats, Nussbaum, and Unamuno, 2007; Llompart et al, 2020, among others) have suggested that at initial stages of development of any language learners need to rely on highly plurilingual practices, such as code-switching or hybrid forms, to conduct the pedagogical tasks at hand, whereas at more advance levels they orient towards what Lüdi and Py (1986 [2002]; 2009) referred to as "unilingual modes of communication", 
which contain 'bricolage' activities. Bange (1992) indicates that speakers, when faced with a communication problem, can choose to (1) abandon their communicative purposes, (2) resort to resources from other semiotic systems or (3) seek interactive solutions, such as asking their interlocutors for help. Relying on one's plurilingual and multimodal repertoire as a scaffolding mechanism to maintain the communication flow is a resource widely employed by speakers when attempting to affiliate to a 'unilingual mode' of communication (see Masats and Noguerol, this volume;Vallejo, this volume). Such practices are vital to observe participation and today they are already seen as necessary for the development of learners' plurilingual competences. These findings explain the incorporation of scales for assessing plurilingual abilities in the Companion Volume of the Common European Framework of Reference for Languages (CERF, Council of Europe, 2018) while they were not present in the first version of the CERF (Council of Europe, 2001).

In participation activities multimodal resources also play a key role. Particularly interesting for us is Goodwin and Goodwin's (2004) postulation that participation is reflected through the actions all participants perform, including the use of gestures, gaze (see Borràs, this volume; Masats and Noguerol, this volume) and multimodal resources like tasks instructions (see, Moore, this volume; Unamuno, this volume), computers (see, in this volume, Dooly, Moore and Vallejo, Nussbaum) and manipulative objects such as, among others, mobile devices (see Dooly and Czura, this volume; Pratginestós this volume), books and dictionaries (see, in this volume, Borràs, Llompart,Vallejo), car spare parts (see Corona, this volume) or clinical and therapy supplies and patients (see Ploettner, this volume). In this sense, the notion of 'embodied participation frameworks' proposed by Goodwin (2007) becomes relevant for the study of participation in plurilingual environments. Consequently, the so-called 'plurilingual turn' (Conteh and Meier, 2014), employed to study interactions in classrooms or in translocal settings, must be integrated in the 'multimodal turn' (Markee, 2015). Video-recordings, thus, allow analysts to uncover what Goodwin (2013) refers to as "the laminated organisation of social action".

\section{Analysing plurilingual practices}

The study of plurilingual interaction stems from research on language contact, but moves away from a normative perspective based on concepts such as language interferences and loans. Hence, Interactional Sociolinguistics adopts a perspective that examines language contact in talk-in-interaction and establishes links between linguistic uses and social forms of participation. Constructs like 'situational code-switching' and 'metaphorical code-switching', coined by Blom and Gumperz (1972), were proposed as an alternative to the concept of diglossia. From a conversational perspective, as Auer points out (Auer, 1984, 1998, 1999), code-switching must be sequentially analysed to unveil when it is 'discourse-related' or 'participant-related'. The first one indicates to the 
participants that something is changing in the organisation of interaction. In Gumperz's (1982) terminology, discourse-related code-switching constitutes a contextualisation cue that gives participants (and hence, makes available to analysts) hints to interpret or re-create the local context of the conversation. Thus, code-switching may indicate that the framework of conversation is modified in some way. The second type of code-switching indexes a preference for using a specific set of resources, preference linked to a lack of competence of the interlocutors or to the exhibition of a specific identity, 'doing being' a speaker of that or that language, for example.

Following the works of Gumpez and Auer, in this volume we analyse plurilingual practices from an emic perspective, that is, by approaching data from the viewpoint of participants. In fact, as Musk and Cromdal (2018) point out in their review of Conversation Analysis and ethomethodological studies on bilingualism in education, determining whether certain linguistic resources belong to a particular language implies projecting an etic perspective on the analysis of data. This is why it is crucial for analysts to refrain from projecting monolingual-biased interpretations of plurilingual practices and, on the contrary, observe the speakers' orientations in each interactional sequence. Hence, in classroom interactions, teachers and students may align to the established linguistic policies and orient themselves towards the "medium of instruction' or opt to employ bi-/plurilingual resources either as a 'medium of classroom interaction' or as a procedure to introduce a non-sequentially implicative switch (Bonacina and Gafaranga, 2011) to solve communication breakdowns.

At the turn of the century, many researchers started to question the notion of 'language' to describe bi-/plurilingual practices and the semiotic resources employed by speakers. They argued that the concept of language is a social construct associated with the grammar of an idealised native speaker. ÁlvarezCaccamo (1998), for example, argued that the association of certain linguistic resources to a particular language was problematic. The "panoply of lingualisms" (Marshall and Moore, 2018) resulting from these discussions to avoid using the term 'language' is sustained by a variety of theoretical foundations we cannot address in this chapter. However, the authors in this volume subscribe to Cummins' (2017) view that languages 'exist' as a social construction in people's life experiences. This implies that people, during talk-in-interaction, orient themselves towards resources belonging to one or another language, regardless of their coincidence with established norms. In turn, these experiences allow them to reflect on differences and similarities between languages (see Llompart, this volume; Masats, this volume). We adopt - as many researchers do - the concept 'repertoire' (Gumperz, 1964) to refer to the set of resources that allow speakers to take part in social interactions. Repertoires are composed of linguistic varieties, dialects, discursive genres, common speech acts and interpretative frameworks (Gumperz, 1982), as well as of semantic and pragmatic configurations used to create or interpret meaning in locally-situated 
interactions, and, of course, of the multimodality embodied in the talk-ininteraction to which we have alluded.

\section{Book sections}

This volume is a collection of samples of classroom interactions in formal and non-formal multilingual educational settings that illustrates diverse practices in which learners put at play their plurilingual repertoire. The analysis of our data, gathered over a period of 25 years in a variety of contexts - with primary or secondary teachers in Catalonia, in university classrooms, in out-of-school educational settings, in translocal spaces - allows readers (language teachers and researchers alike) to delve into what occurs in educational settings in which participants put into play their linguistic repertoire to construct knowledge, negotiate their social identities or create personal bonds while they develop their plurilingual and interactional competence and conduct pedagogical tasks to learn a language or other curricular contents. The book also contains samples of interactions mediated by computer and cell phones, which can be regarded as participants in the tasks at hand.

There are two main interests that guide this compilation. First, in order to understand the sociolinguistic and interactional dynamics in classrooms and other learning spaces, we want to take a retrospective look at the work done with the objective of examine data from a renewed perspective while we also incorporate new scenarios and learning modes. Second, we consider it is our obligation to return to society, which has financed our research, the results of the work we have carried out.

In most chapters, Conversation Analysis is adopted as a framework to study the emergence of plurilingual activities in interaction. This perspective examines the way in which people use their linguistic and multimodal resources to carry out practical activities by creating aspects of the social structure, on which plurilingual practices are contingent. Speakers, thus, categorise their orientation towards the educational institution, towards their preferences or towards their competences and exhibit, at the same time, one of their different discursive or situated identities (Zimmermann, 1998). Membership Categorization Analysis could be congruent to the sequential analysis of the interaction since it contributes not only to understanding the construction of identities in the interaction, but also to the critical study of categories such as apprentice, teacher, expert, etc. Speakers may make these categories explicit, but often do so in interaction through category-bound activities. In the remaining chapters, authors are inspired by other orientations such as Ethnography of Communication, Educational Sociolinguistics and Socio-interactional Learning Theories. Often, these approaches are complementary orientations to explain situated cognition in the sense that every cognitive activity is a response to the demands of the social, organisational and contextual circumstances in which it is accomplished (Resnick, 1991; Mondada and Pekarek Doehler, 2004). 
Analysing plurilingual talk-in-interaction implies recording and transcribing oral data. As transcribing is a preliminary analysis, this task has been conducted individually by the authors of this volume before socialising the outcomes with other team members in data sessions organised for this purpose. In the annex to this chapter we detail the transcription symbols employed in the chapters. We opted for a simplified codification, adapted from the orientations provided by Jefferson (1984).

The volume is divided into six sections which highlight different aspects of plurilingual interaction. Each chapter contains a brief theoretical framework and descriptions of interactions with the aim of inspiring teachers and researchers worldwide to better understand the role of plurilingual resources in the interactional construction of meaning in educational settings. Our interest is to show the links between plurilingual practices and participation in the ongoing interaction. We do not intend to document learning, since in most cases we do not present longitudinal data (see, however, the chapters by Borràs and Moore in this volume). Instead, we document interactions containing plurilingual and multimodal sequences that, observed from a Vygotskyan microgenetics perspective, illustrate 'sequences of potential acquisition' of various aspects of language use (de Pietro, Matthey, and Py, 1989).

The first section is composed of three chapters that present interactions conducted by teachers who promote plurilingual practices. Chapter 1, authored by Josep M. Cots, and Chapter 2, co-authored by Eulàlia Borràs and Luci Nussbaum, analyse data collected in university classrooms in which English is planned as the medium of instruction. Chapter 3, co-authored by Dolors Masats and Artur Noguerol, examines the case of two primary school teachers who welcome parents into the classroom to legitimise the use of heritage languages. The second section comprises three chapters, authored respectively by Claudia Vallejo, Júlia Llompart and Luci Nussbaum. All study plurilingual interactions led by learners who adopt the role of instructors for their teachers or their peers. The third section comprises the contributions by Virginia Unamuno and Dolors Masats. Both chapters illustrate plurilingual speakers' ability of 'doing being sociolonguists', since participants in the study exhibit capacities to reflect upon language uses in their communities of practice and to construct context. The fourth section is devoted to the study of multimodal interaction in university classrooms. It comprises three chapters authored respectively by Eulàlia Borràs, Joan Ploettner and Emilee Moore. The fifth section is composed of two chapters on computer-mediated interactions, one authored by Melinda Dooly and the other co-authored by Emilee Moore and Claudia Vallejo. Finally, the sixth section compiles three chapters that examine translocal plurilingual interactions. They are respectively authored byVíctor Corona, Cèlia Pratginestós and co-authored by Melinda Dooly and Anna Czura.

To sum up, our volume aims to be a contribution to gain a deeper understanding of plurilingual education. Although our studies examine plurilingual practices of students, children and parents in Catalonia, our results 
can relate to wider plurilingual milieus because (1) the plurilingual practices in our data include diverse languages (namely Arabic, Catalan, English, French, Greek, Mandarin, Punjabi, Riffian Berber, Spanish and Urdu), (2) we examine how learners display their plurilingual repertoires in language classrooms, mainstream classrooms and in technology-mediated milieus in a variety of educational settings (primary schools, secondary schools, vocational training centres, out-of-school educational establishments and universities) and (3) most of the chapters pay special attention to multimodality. Our data reveals that plurilingual practices are not only relevant as scaffolding tools to develop mastery in languages, but also resources to gain linguistic and field knowledge necessary to participate in multiple pedagogical and social tasks. Similarly, our analyses reveal that plurilingual activities are sensitive to the current task, situation, speakers' expectations, rights and obligations, etc. and can index competences and preferences, identified in their local occurrence. Therefore, we conclude that plurilingual educational practices and policies must stem from a deep understanding of the phenomena that occur both in talk-ininteraction in multicultural and multilingual classrooms and in translocally situated technology-mediated learning spaces.

\section{References}

Álvarez-Caccamo, C. (1998). From 'switching code' to 'code-switching'. Towards a reconceptualization of communicative coses. In P. Auer (Ed.), Code-switching in conversation. Language, interaction and identity (pp. 29-48). London/New York: Routledge.

Auer, P. (1984). Bilingual conversation. Amsterdam: John Benjamins.

Auer, P. (1998). Bilingual conversation revisited. In P. Auer (Ed.), Code-switching in conversation. Language, interaction and identity (pp. 29-48). London/New York: Routledge.

Auer, P. (1999). From codeswitching via language mixing to fused lects: Towards a dynamic typology of bilingual speech. International Journal of Bilinguism, 3, 309-332.

Bange, P. (1992). A propos de la communication et de l'apprentissage de L2 (notamment dans ses formes institutionnelles). Acquisition et Interaction en Langue Estrangère: AILE, 1, 53-85.

Blom, J. P., \& Gumperz J. (1972). Social meaning in linguistic structure: Code-switching in Norway. In J. Gumperz, \& D. Hymes (Eds.), Directions in sociolinguistics (pp. 407434). New York: Holt, Rinehart and Winston.

Blommaert, J., \& Backus, A. (2011). Repertoires revisited: 'Knowing language' in superdiversity. Working Papers in Urban Language and Literacies, 67, 1-26.

Bonacina, F., \& Gafaranga, J. (2011). 'Medium of instruction' versus 'medium of classroom interaction': Language choice in a French complementary school classroom in Scotland. International Journal of Bilingual Education and Bilingualism, 14(3), 319-334.

Bonacina-Pugh, F. (2012). Researching 'practiced language policies': Insights from conversation analysis. Language Policy, 11, 213-234.

Conteh, J., \& Meier, G. (Eds.) (2014). The multilingual turn in languages education: Opportunities and challenges. Bristol: Multilingual Matters.

Constitución Española (1978). Boletín Oficial del Estado, 29 de diciembre de 1978, núm. 311, pp. 29313-29424. 
Coste, D., de Pietro, J. F., \& Moore, D. (2012). Hymes et le palimpseste de la cómpetence de communication. Tours, détours et retours en didactique des langues. Langage et Societe, 139, 103-123.

Coste, D., Moore, D., \& Zarate, G. (1997). Competénce plurilingue et pluriculturelle: Vers un cadre europeén commun de référence pour l'enseignement et l'apprentissage des langues vivantes. Strasbourg: Éditions du Conseil de l'Europe.

Council of Europe (2001). Common European framework of reference for languages: Learning, teaching, assessment. Strasbourg: Council of Europe Publishing.

Council of Europe (2018). Common European framework of reference for languages: Learning, teaching, assessment - Companion volume. Strasbourg: Council of Europe Publishing.

Cummins, J. (2017). Teaching for transfer in multilingual educational contexts. In O. Garcia \& A. Lin (Eds.), Encyclopedia of language and education: Bilingual education. (pp. 103-115). New York: Springer Science + Business Media.

de Pietro, J. F., Matthey, M., \& Py, B. (1989). Acquisition et contrat didactique: Les séquences potentiellement acquisitionnelles dans la conversation exolingue. In D. Weil \& H. Fugier (Eds.), Actes du troisième colloque régional de linguistique (pp. 99-124). Strasbourg: Université des Sciences Humaines et Université Louis Pasteur.

Departament d'Ensenyament (2018). The language model of the Catalan education system: Language learning and use in a multilingual and multicultural educational environment. Barcelona: Generalitat of Catalonia / Ministry of Education. Available at: http:// educacio.gencat.cat/web/.content/home/departament/publicacions/monografies/ model-linguistic/model-linguistic-Catalunya-ENG.pdf.

Dooly, M., \& Masats, D. (2019). 'What do you zinc about the project?': Examples of technology-enhanced project-based language learning. In G. Beckett \& T. Slater (Eds.), Global perspectives on project-based language learning, teaching, and assessment: Key approaches, technology Tools, and frameworks (pp. 126-145). NY/Milton Park, Abingdon: Routledge.

Duranti, A., Ochs, E., \& Schieffelin, B.B. (Eds.). (2011). The handbook of language socialization. Malden:Wiley-Blackwell.

Estatut d'Autonomia de Catalunya. Passed in 1979. Revised on July 19, 2006. Available at: http://web.gencat.cat/ca/generalitat/estatut.

Goodwin, C. (2007). Participation, stance, and affect in the organization of activities. Discourse and Society, 18(1), p. 53-73.

Goodwin, C. (2013). The co-operative, transformative organization of human action and knowledge. Journal of Pragmatics, 46(1), 8-23.

Goodwin C., \& Goodwin, M. H. (2004). Participation. In A. Duranti (Ed.), A companion to linguistic anthropology (pp. 222-244). Oxford: Basil Blackwell.

Gumperz, J. (1964). Linguistic and social interaction in two communities. American Anthropologist, 66(6/2), 137-153.

Gumperz, J. (1982). Discourse strategies. Cambridge: Cambridge University Press.

Hall, J. K., Hellermann, J., \& Pekarek-Doehler, S. (Eds.). (2011). L2 Interactional competence and development. Bristol: Multilingual Matters.

Hymes, D. (1972). On communicative competence. In J. B. Pride \& J. Holmes (Eds.), Sociolinguistics. Selected readings (pp. 269-293). Harmondsworth: Penguin Books.

Hymes, D. (1973). Toward linguistic competence. Working Papers in Sociolinguistics, 16. Austin, TX: Centre for Intercultural Studies in Communication, and Department of Anthropology, University of Texas.

Idescat (2020). Evolució de la població total i estrangera (2000-2019). Barcelona: Institut d'Estadística de Catalunya. Available at: www.idescat.cat/poblacioestrangera/? $\mathrm{b}=0$. 
Jefferson, G. (1984) Transcript notation. In J. M. Atkinson \& J. Heritage (Eds.), Structures of social action: Studies in conversation analysis (pp. ix-xvi). Cambridge: Cambridge University Press.

Kasper, G., \& Wagner, J. (2011). A conversation-analytic approach to second language acquisition. In D. Atkinson (Ed.), Alternative approaches to second language acquisition (pp. 117-142). Taylor \& Francis. https://doi.org/10.4324/9780203830932.

Kunitz S., \& Markee, N. (2017) Understanding the fuzzy borders of context in conversation analysis and ethnography. In S. Wortham, D. Kim, \& S. May (Eds.), Discourse and education. Encyclopedia of language and education (pp. 15-27). Berlin: Springer. https:// doi.org/10.1007/978-3-319-02243-7_8.

Lantolf, J., \& Thorne, S. L. (2006). Sociocultural theory and the genesis of second language development. Oxford: Oxford University Press.

Lave, J., \& Wenger, E. (1991). Situated learning: Legitimate peripherical participation. New York: Cambridge University Press.

Llompart, J., \& Nussbaum, L. (2018). Doing plurilingualism at school: Keys concepts and perspectives. In S. Melo-Pfeifer \& C. Helmchen (Dirs.), Plurilingual literacy practices at school and in teacher education (pp. 19-39). Bern: Peter Lang

Llompart, J., Masats, D., Moore, E., \& Nussbaum, L. (2020). Mézclalo un poquito. International Journal of Bilingual Education and Bilingualism, 23(1), 98-112. https://doi. org/10.1080/13670050.2019.1598934.

Lüdi, G., \& Py, B. (1986 [2002]). Etre bilingue. Bern: Peter Lang.

Lüdi, G., \& Py, B. (2009). To be or not to be... a plurilingual speaker. International Journal of Multilingualism, 6(2), 154-167.

Markee, N. (Ed.). (2015). The handbook of classroom discourse and interaction. Oxford:Wiley Blackwell.

Markee, N., \& Kasper, G. (2004). Classroom talks: An introduction. Modern Language Journal, 88, 491-500.

Marshall, S., \& D. Moore (2018). Plurilingualism amid the panoply of lingualisms: Addressing critiques and misconceptions in education. International Journal of Multilingualism, 15(1), 19-34.

Masats, D., \& Guerrero, P. (2018). The ins and outs of teamworking: When university teachers, in-service secondary teachers and pre-service teachers collaborate to transform learning. European Journal of Social Science Education and Research, 5(3), 185-193.

Masats, D. \& Noguerol, A. (2016). Proyectos lingüísticos de centro y currículo. In D. Masats \& Luci Nussbaum (Eds.), Enseñanza y aprendizaje de las lenguas extranjeras en educación secundaria obligatoria (pp. 59-84). Madrid: Síntesis.

Masats, D., Dooly, M., Juanhuix, M., Moore, E., \& Vallejo, C. (2021). Working together to innovate: Collaboration between teachers and researchers in plurilingual contexts. In D. Masats \& C. Pratginestós (Eds.), L'aula com a àmbit d'investigació sobre l'ensenyament i l'aprenentatge de la llengua / El aula como ámbito de investigación sobre la enseñanza y el aprendizaje de la lengua / A aula como contexto de investigação sobre o ensino e a aprendizagem de lingua / The classroom as a site for research on language teaching and learning. Bern: Peter Lang.

Masats, D., Nussbaum, L., \& Unamuno,V. (2007). When the activity shapes the repertoire of second language learners. In L. Roberts, A. Gürel, S. Tatar, \& L. Marti (Eds.), EUROSLA Yearbook: Volume 7 (pp.121-147). Amsterdam: John Benjamins.

Mondada, L. \& Nussbaum, L. (Eds.) (2012). Interactions cosmopolites: L'organisation de la participation plurilingue. Limoges: Editions Lambert Lucas. 
Mondada, L., \& Pekarek Doehler, S. (2004). Second language acquisition as situated practice:Task accomplishment in the French second language classroom. The Modern Language Journal, 88 (4), 501-518.

Moore, E. \& Nussbaum, L. (2014). Building a multilingual university in institutional policies and everyday practices. In J. W. Unger, M. Krzyżanowsk, \& R. Wodak (Eds.), Multilingual encounters in Europe's institutional spaces (pp. 243-269). London: Continuum.

Moore, E., Ploettner, J., \& Deal, M. (2015). Exploring professional collaboration at the boundaries between content and language teaching from a CHAT approach. Ibérica, 30, 85-104.

Moore, E., \& Tavares, G. (2020). Telling the stories of youth: Co-producing knowledge across social worlds. In E. Moore, J. Bradley, \& J. Simpson (Eds.), Translanguaging as transformation: The collaborative construction of new linguistic realities (pp. 155-174). Bristol: Multilingual Matters.

Musk, N., \& Cromdal, J. (2018). Analysing bilingual talk. In A. Filipi \& N. Markee (Eds.), Conversation analysis and language alternation: Capturing transitions in the classroom (pp. 15-34). Amsterdam: John Benjamins.

Nussbaum, L. (2017). Doing research with teachers. In E. Moore \& M. Dooly (Eds.), Qualitative approaches to research on plurilingual education / Enfocaments qualitatius per a la recerca en educació plurilingüe / Enfoques cualitativos para la investigación en educación plurilingüe (pp. 46-67). Dublín, Irlanda/Voillans, France: Research-publishing.net. https://doi.org/10.14705/rpnet.2017.emmd2016.621.

Nussbaum, L., \& Unamuno,V. (2006). Les competències comunicatives multilingües. In L. Nussbaum \&V. Unamuno (Eds.), Usos i competències multilingües entre escolars d'origen immigrant (pp. 41-61). Bellaterra: Servei de publicacions de la Universitat Autònoma de Barcelona.

Pekarek Doehler, S. (2005). De la nature située des compétences en langue. In J. P. Bronckart, E. Bulea, \& M. Puoliot (Eds.), Repenser l'enseignement des langues: Comment identifier et exploiter les compétences (pp. 41-68).Villeneuve d'Ascq: Presses universitaires du Septentrion.

Pekarek Doehler, S. (2013). Social-interactional approaches to SLA: A state of the art and some future perspectives. Language, Interaction and Acquisition, 4(2), 134-160.

Pekarek Doehler, S., \& Fasel Lauzon, V. (2015). Documenting change across time: Longitudinal and cross-sectional CA studies of classroom interaction. In N. Markee (Ed.), The handbook of classroom discourse and interaction (pp. 409-424). Oxford:Wiley Blackwell.

Resnick, L. B. (1991). Shared cognition: Thinking as social practice. In L. B. Resnick, J. M. Levine, \& S. D. Teasley (Eds.), Perspectives on socially shared cognition (pp. 1-20). Washington, DC: American Psychological Association.

Sook Lee, J., \& Bucholtz, M. (2015). Language socialization across learning spaces. In N. Markee (Ed.), The handbook of classroom discourse and interaction (pp. 319-336). Oxford:Wiley Blackwell.

Star, S. L., \& Griesemer, J. R. (1989). Institutional ecology, "translations” and boundary objects: Amateurs and professionals in Berkeley's Museum of Vertebrate Zoology, 1907-1939. Social Studies of Science, 19, 387-420. doi:10.1177/0306312890 19003001.

Thorne, S. L., \& Hellermann, J. (2015). Sociocultural approaches to expert-novice relationships in second language interaction. In N. Markee (Ed.), The handbook of classroom discourse and interaction (pp. 281-298). Oxford: Wiley Blackwell. 
Wenger, E. (1998). Communities of practice: Learning, meaning and identity. Cambridge: Cambridge University Press.

Young,R.F.(2008). Language and interaction:An advanced resource book.Abingdon:Routledge. Zimmerman, D. H. (1998). Identity, context and interaction. In C. Antaki \& S. Widdicombe (Eds.), Identities in talk (pp. 87-107). London: Sage.

\section{Annex}

Annex 1. Transcription symbols used in this volume

Pseudonym of speaker:

STU:

Intonation

a. Falling: \

b. Rising: /

c. Maintainig _

Pauses:

a. Timed: $\left(\mathrm{n}^{\circ}\right.$ seconds)

b. Untimed: (.) (..)

Overlapping: [text]

Latching: =

Interruption: text-

Lengthening of a sound: text

LOUD

${ }^{\circ}$ soft $^{\circ}$

$<$ slow $>$

$>$ fast $<$

Incomprehensible fragment: $\mathrm{xx}$

Best guess at unclear fragment: (text?)

Approximate phonetic transcription: + text+

Continuation of a previous turn: STU $>$

Transcriber's comments: ((comment))

Romanisation of Arabic: $\{$ text

Point when a screen shot was taken: ${ }^{\text {Figure1 }}$

Language (as oriented to by speakers):
a. Catalan
b. English
c. Spanish
d. Could be Catalan or Spanish
d. Other languages

Translations: shaded 
Part I

Teachers promoting plurilingual practices 


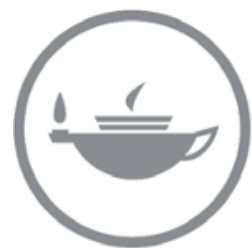

Taylor \& Francis Taylor \& Francis Group http://taylorandfrancis.com 


\title{
Going out on a limb? \\ Introducing a plurilingual perspective in a university business English subject
}

\author{
Josep M. Cots
}

\section{Introduction}

This study is intended to explore how an English for Specific Purposes (ESP) university instructor interprets her role as someone who embraces a plurilingual perspective through particular classroom discourse behaviour. As will be shown in the analysis, the instructor's discourse behaviour involves issues related to the legitimisation of her professional stance, the raising of the students' awareness of particular views about language learning and use, and the adoption of plurilingual practices both on her part and on the part of the students. The relevance of the study is that it focuses on an aspect of the instructor's task for which she was very much left to herself during the process of designing the materials for the pilot teaching intervention reported in this paper. Therefore, the analysis of the data sheds light upon the process of discourse construction that can support the introduction of a plurilingual perspective in a teaching and learning environment that has been traditionally dominated by a monoglossic perspective.

The concept of 'plurilingual competence' proposed by the Council of Europe (2001) is based on the premise that "plurilinguals have a single, inter-related, repertoire that they combine with their general competences and various strategies to accomplish tasks" (Council of Europe, 2018: 28). The development of the concept triggered the need for the adoption of "pluralistic approaches to languages and cultures", that is for "didactic approaches which use teaching / learning activities involving several (i.e. more than one) varieties of languages or cultures" (Candelier et al, 2007: 7). Theoretical and empirical support for adopting a plurilingual approach to second and foreign language learning can be found in the work of Cummins $(2005,2009)$, from which it is possible to derive the following conclusions: the learners' knowledge of previously learnt languages is a useful scaffolding framework for the acquisition of concepts and knowledge related to a new language; translation is part of the everyday life of bi/multilinguals and therefore it can be adopted as a teaching technique to promote the learners' awareness of their increasing communicative repertoire; 
a focus on shared lexical structures in different languages can speed up the learners' acquisition of an additional language.

\section{A 'plurilingual approach' to ESP teaching}

The teaching of English, as well as other foreign languages, can be said to have been dominated until recently by what scholars like Hall and Cook (2012: 275) define as a dogma of "monolingual teaching" and Cenoz and Gorter (2013:591) see as a "policy of language isolation in TESOL". Yet, these same voices, among several others, suggest there is a need for ceasing to teach English in isolation from other languages in the curriculum. The idea departs from research in the field of plurilingual education, which has demonstrated that the mobilisation of teachers' and students' plurilingual resources, and especially the reliance on specific procedures such as code-switching, facilitates comprehension of contents taught through a foreign language, the construction of discipline knowledge and the development of that same foreign language (Duverger, 2007). In this sense, Moore, Nussbaum, and Borràs (2012) suggest that the teachers' use of plurilingual modes of communication is a resource for the management of participation, comprehension, attention and complexity. Other studies have focused on the role of learners' own language(s) as a scaffolding tool. Kerr (2019:10) suggests three main 'classroom management techniques' to include learners' own language in classroom interactions: sandwiching, bilingual instructions and own-language moments. In 'sandwiching' the teacher speaks in English, but translates and repeats in English difficult terms or expressions. In the case of 'bilingual instructions' the teacher first gives the instructions in English and asks a student to repeat the instructions in the L1. Finally, in 'ownlanguage moments' the students can use their own language in order to prepare themselves to use the target language, to reflect about the learning process or to evaluate themselves.

Creese and Blackledge (2010) suggest that the learners' use of other languages with which they are familiar can increase their feeling of inclusion, their participation and understanding (especially of those learners who are at less advanced levels) and the development of less formal relationships (e.g. among learners and between learners and their teacher), which will facilitate the process of conveying ideas and, consequently, of accomplishing lessons. Along this line, Hall and Cook (2012) consider that since "own-language use is not only inevitable within the language classroom, but contributes positively to new language development" (p. 294), it needs to be incorporated as a pedagogic resource.

An important aspect of adopting a plurilingual approach in the context of the present study, a business English course module, is Williams' (2002: 29) idea of translanguaging practices as "a natural way of developing and strengthening both languages". In this sense, it can be assumed that the competence of first-year students in the specific 'business register' was not only low in the 
target language but also in their own language(s). Thus, the introduction of a plurilingual approach can represent a transformation of the course module from business English into business communication skills in three languages: English, Catalan and Spanish.

\section{Methodology}

In this chapter, I will examine the plurilingual practices of an ESP instructor teaching at a university in Catalonia. I will focus on three aspects: (1) How does the instructor legitimise her plurilingual approach in front of students who have been mainly exposed to a monoglossic approach to foreign language teaching/learning? (2) What model of language learning and use does the instructor project through her 'interpretation' of the materials and her management of the teaching/learning process? (3) How does the instructor discursively enact her role in correspondence with her heteroglossically-inspired materials and ideology?

The data analysed in this section correspond to the transcribed audiorecordings of the instructor's talk in three different sessions, which took place in weeks one, six and 12 of a 15-week term. The analysis centres on Goffman's notion of discourse 'move' (1981:24), by which he refers to "any full stretch of talk or of its substitutes which has a distinctive unitary bearing on some set or other of the circumstances in which participants finds themselves (some 'game' or other in the peculiar sense employed by Wittgenstein)". For Goffman, "a move may sometimes coincide with a sentence and sometimes with a turn's talk but need do neither".

This study is based on the premise that in order to fully understand the impact of introducing a plurilingual approach in language teaching it is necessary to carefully examine the communicative practices of both teachers and students. In this case, the analysis focuses on three particular types of moves or strategies adopted by the instructor, which are interpreted as aimed at legitimising her

plurilingual approach, representing the process of language learning and use and enacting her pedagogic role in a consistent way with a plurilingual approach.

\section{Analysis}

\section{Legitimation}

One of the features of the instructor's discourse that calls the attention in the analysis of the first class session is her attempt to present her plurilingual approach as a legitimate experimental alternative to what she assumes has been the dominant monoglossic approach the students have been exposed to and would expect for the subject. She first adopts a legitimation-by-authorisation strategy (van Leeuwen, 2007), as we can see in excerpt 1. Right at the beginning of the first class, the instructor (INS) makes sure that the students understand 
that they will take part in a carefully planned innovative educational experience, to which she refers as "projecte/project", and that this experience has been approved by the Faculty ("un projecte aprovat per la facultat /a project approved by the faculty"):

Excerpt 1 (session 1). Participant: Instructor (INS)

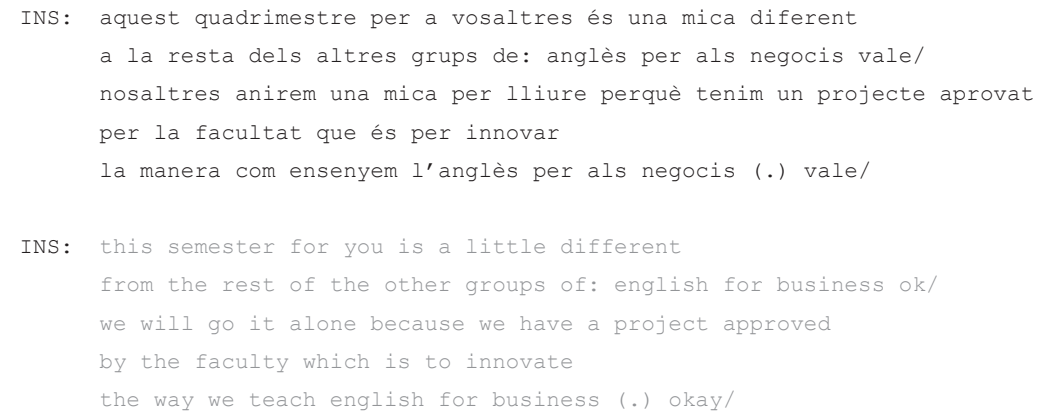

Another legitimation strategy employed by the teacher in our data is rationalisation (van Leeuwen, 2007). Thus, she makes reference to the benefits of her actions, in this case the leaners' possibility to acquire or improve specific communicative skills (i.e. writing a business letter, giving a sales pitch) not only in English but also in Catalan and Spanish. In excerpt 2 we can see how the instructor uses her personal experience (line 6) to justify her decision to include business letters in Catalan and Spanish as foundation stage for learning to write business letters in English (lines 7 and 8).

\section{Excerpt 2 (session 1). Participant: Instructor (INS)}

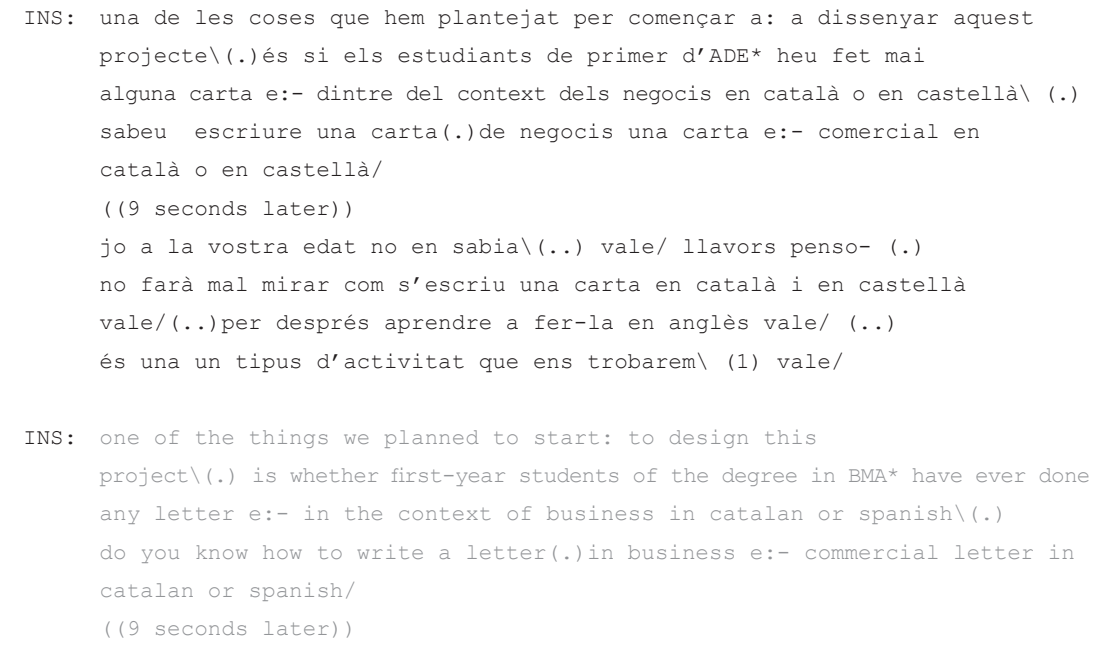




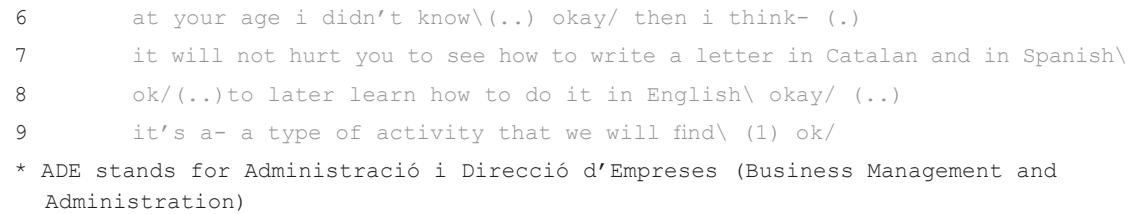

\section{Representing language learning and use}

In this section, I focus on specific discourse moves through which the instructor constructs a particular model of language learning and use that she deems compatible with her plurilingual approach. This model is based on three main elements: (1) the idea that learners' communicative competence is developed when they engage in particular communicative tasks whose resolution essentially involves assembling different parts or components, (2) the relevance of the interpersonal function of language use, and (3) a reliance on the learners' capacities to transfer knowledge and skills from their L1 to the foreign language.

The task orientation adopted in the course module is reinforced by the instructor's focus on the productive skills, writing and speaking, which are necessary to carry out two specific tasks related to their academic profile in the field of business management and administration: commercial correspondence and sales pitch. The instructor envisages learners' communicative competence as the accumulation of successful performances in a series of independent tasks that form part of the communicative repertoire of a business professional. Success is presented by the instructor as a 'technical' matter resulting from assembling a series of rhetorical moves, which are realised by means of specific sentences, in a particular order. It is also interesting to point out that the instructor usually comments on the function of these discourse moves without referring to a specific language, thereby suggesting that the move structure of the communicative task is valid for different languages. In excerpt 3 we can see that the instructor presents the first move in a sales pitch by repeating the modal construction 'have to + verb' (lines 3 and 4) to emphasise what she considers to be an essential aspect of a sales pitch, which is the innovative nature of the product (line 5):

Excerpt 3 (session 3). Participant: Instructor (INS)

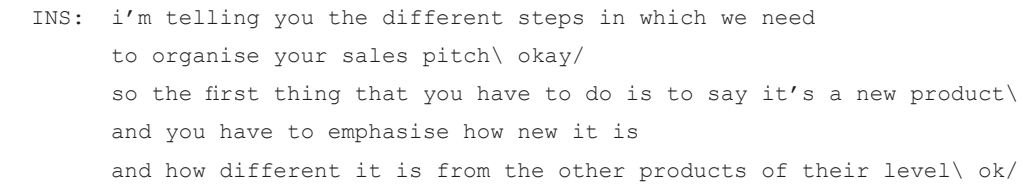

In excerpt 4, we can see that after the students have become familiar with the move structure of the text, the instructor asks them to memorise what Pawley 
and Syder (1983: 191-192) refer to as "lexicalised sentence stems" (lines 1-3), that is, units "of clause length or longer whose grammatical form and lexical content is wholly or largely fixed; its fixed elements form a standard label for a culturally recognised concept, a term in the language". Then the instructor switches into Catalan to legitimise, through rationalisation, the adoption of this technique (lines 4-6).

Excerpt 4 (session 3). Participant: Instructor (INS)

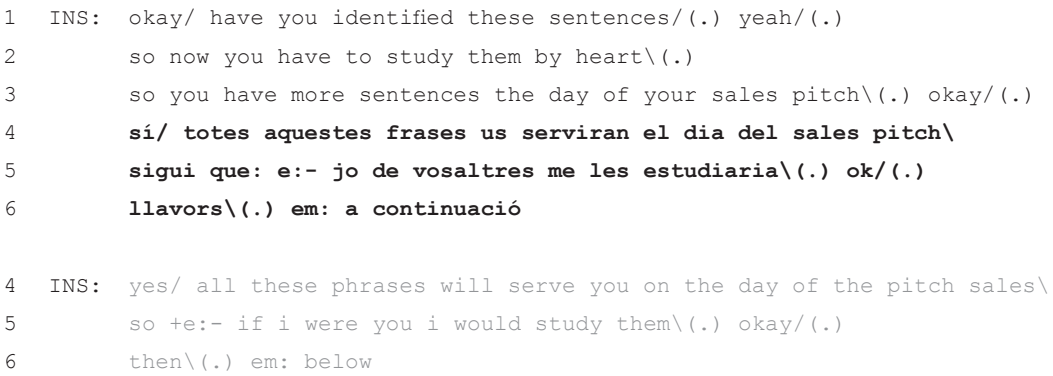

Apart from defining the sequence of discourse moves that are necessary for the successful performance of the communicative task, the instructor invests a substantial amount of her discourse in raising the students' awareness of the relevance of the interpersonal function of language. In excerpt 5 we can see her pointing out in Catalan the two main components of her feedback on a students' essay: "contingut/content" (discourse moves) (line 2) and "formalitat/ formality" (interpersonal elements) (line 4):

Excerpt 5 (session 2). Participant: Instructor (INS)

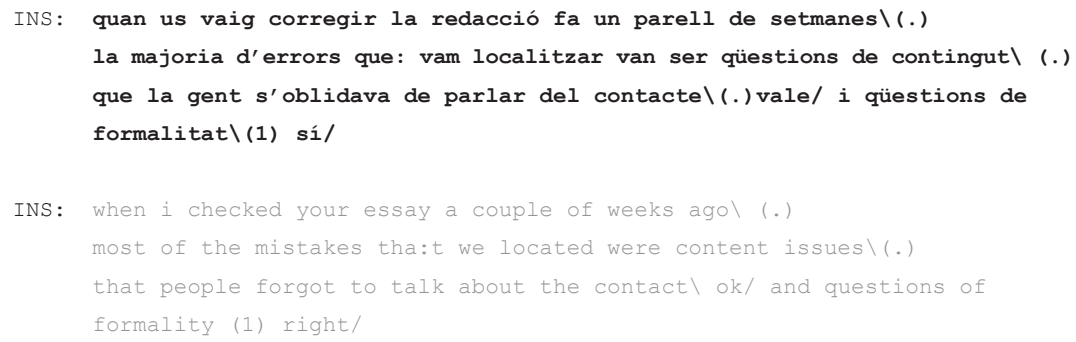

In line with her plurilingual approach, it is possible that the instructor may also consider relaxing the prescriptive nature of language use that characterises a monoglossic perspective. In excerpt 6, for example, she discusses in Catalan different 'lexicalised sentence stems' (Pawley and Syder, 1983) used in business letters (lines 2-4). In the first part of the excerpt the instructor refers to the conventional nature of the opening and closing expressions that she introduces 
(line 2: "això és una convenció en anglès / this is a convention in English"), but she employs a prescriptive tone by using a future tense to express obligation (line 4: "no acabarem mai amb un "yours sincerely' $\backslash$ vale/ we will never end with 'yours sincerely', ok/"). Nevertheless, in the second part of the excerpt, she seems to adopt a less prescriptive tone by relativising the seriousness of the error (line 6) on the basis of the degree of tolerance of the potential addressees (line 7) or their status as non-native speakers (lines 9-10).

Excerpt 6 (session 2). Participant: Instructor (INS)

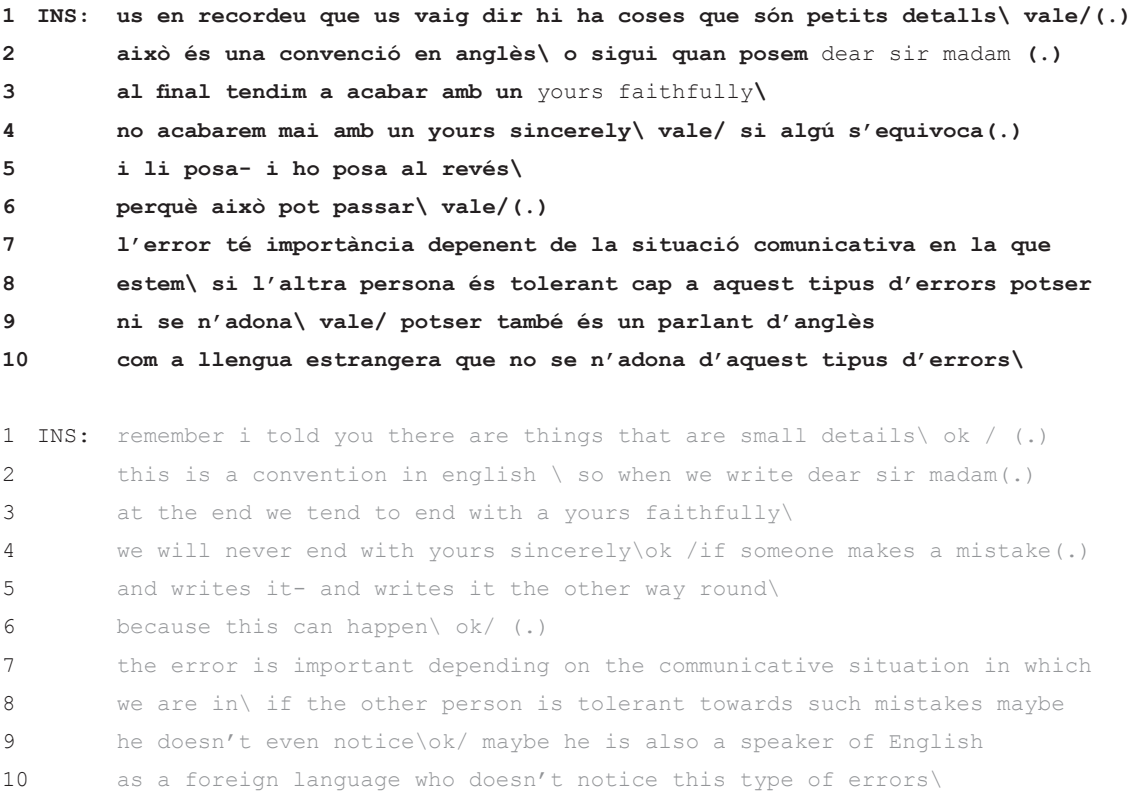

The instructor's emphasis on the interpersonal function of language, to which she refers as "formalitat/formality", appears mainly in the session focusing on business letters. In this same session, it seems clear that her 'technical' approach to communication involves the assemblage of a series of 'parts' (i.e. rhetorical moves), as it becomes evident in excerpt 7 . We can see how a student's request about the meaning of the lexical item "hesitate" (line 4) allows her to present students a closing sentence which she characterises as "xula/cool" (line 7).

Excerpt 7 (session 2): Participants: Instructor (INS), Students (S03, S06, S07 \& S11).

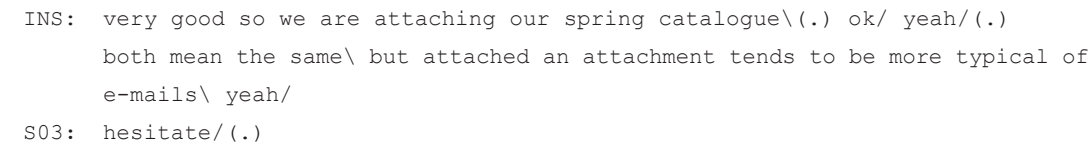


5 INS: hesitate $($ (.) anyone knows hesitate /(..) sabeu què vol dir hesitate/

6 S11: dubtar $\backslash($.

hesitate $\backslash(\cdot)$

7 INS: està molt bé e: aquesta pregunta perquè aprendrem una frase molt xula $\backslash($. very good te: t this question because we will learn a very cool expression $\backslash($.

8 S06: dubtar $\backslash($.

hesitate $\backslash($.)

9 S07: dubtar

hesitate

10 INS: molt bé dubtar molt bé o sigui amb una carta com aquesta podem dir very well doubt very well i.e. with a letter like this we can say do not no dubti- si us plau no dubti en posar-se amb contacte amb nosaltres si hesitate please do not hesitate to contact us if

The instructor's 'technical' approach to communication that I referred to above is complemented, for example, by referring to the set of formal characteristics as a specific area of the scientific study of language ("llenguatge persuasiu/persuasive language"), which requires both understanding and practice, as shown in excerpt 8.

Excerpt 8 (session 2). Participant: Instructor (INS)

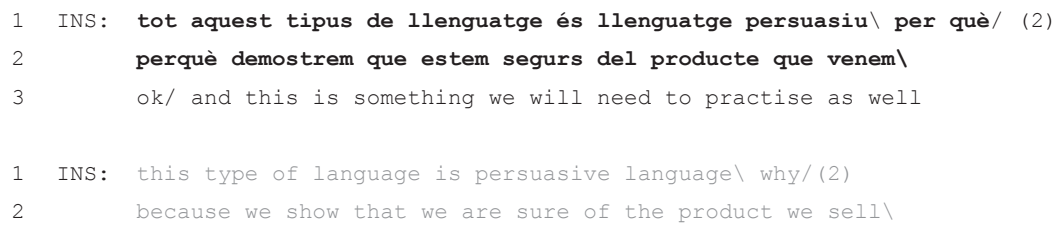

A third characteristic of the model of language learning and use that the instructor seems to project to the students is her reliance on Cummins' (2005:2) idea that "concepts, academic content, and learning strategies transfer across languages" and that an important role of the instructor is to promote and facilitate, rather than impede, that the students can make this transfer. This is what she expresses in excerpt 9, in which she addresses the students in Catalan to present the task of writing a letter in Catalan as a preparatory step to writing one in English (lines 2-4).

Excerpt 9 (session 1). Participant: Instructor (INS)

1 INS: l'objectiu és e: que no ens confonguem/(.) l'objectiu principal-

2 el focus està en saber escriure una carta en anglès $\backslash($. 


\section{Interacting and modelling}

Teacher talk does not only serve as a source of foreign language input for the students, but also as a model of language use. From a monoglossic perspective, the only legitimate language in the classroom is the target language and the teacher should avoid using the learners' L1 in order to maximise the students' exposure to the target language and to enact a 'good' monolingual model of use. Therefore, from a plurilingual perspective, one of the challenges teachers face is how to exhibit an appropriate behaviour for a plurilingual speaker, which entails two apparently conflicting discursive actions: presenting a model for the use of the target language and legitimising the use of other languages as scaffolding devices whenever the situation requires it.

One way in which the instructor enacts her plurilingual perspective through her talk is by means of a variation of the 'sandwiching' technique (Kerr, 2019), which involves the translation of a problematic word or expression into the students' L1 to immediately continue her discourse in English. In excerpt 10 we can see that the instructor decides to translate into Catalan the second question in her turn (lines 4-5) in order to facilitate the students' understanding of their main task but, at the same time, keeps the technical term in English to refer to the targeted type of text ("reply to an inquiry", line 5):

Excerpt 10 (session 2). Participant: Instructor (INS), Student (S04)

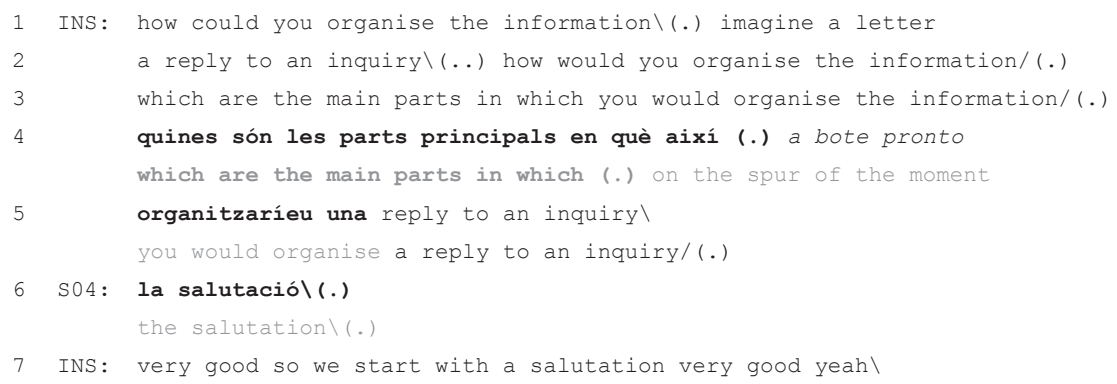

This same excerpt is also illustrative of the instructor's acceptance of the students' use of Catalan to respond to her questions in English.Yet, occasionally 
we observe that the instructor seems to 'go monolingual', as in excerpt 11. In these cases, although she still accepts responses in the students' own language (line 8), she resorts to English to clarify meaning. We can see that in this specific case, in order to clarify the meaning of certain expressions, the instructor resorts to 'monolingual techniques' such as paraphrasing (lines 4-5), suggesting synonym expressions (line 9) or engaging students in reverse translation from Spanish (line 11) or Catalan (line 21) into English.

Excerpt 11 (session 3). Participants: Instructor (INS), Student (S09)

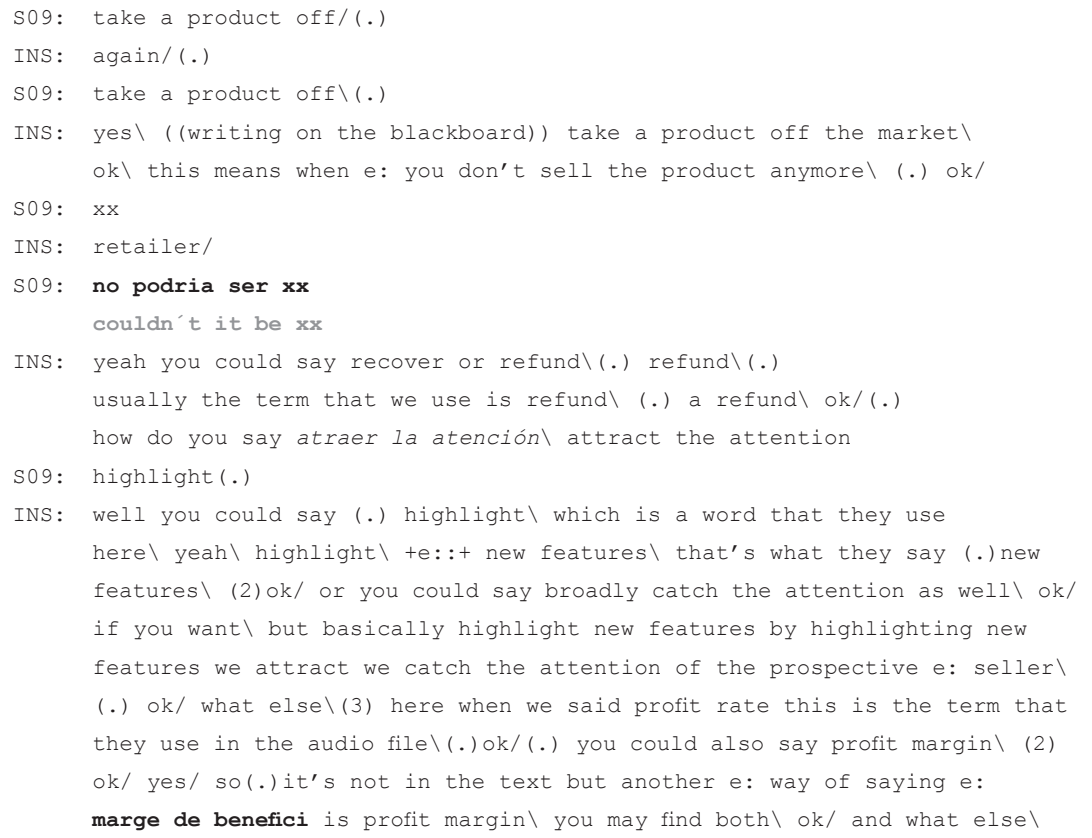

The scaffolding function of leaners' own languages can be seen in the fact that they are not only allowed by the instructor as tools for communication among students in order to complete a group task, but also as a means to focus on meaning. This is what we can see in excerpt 12.

Excerpt 12 (session 2). Participant: Instructor (INS)

1 INS: so now in small groups yeah/(.) try to answer these two questions

2 here $x x$ in in any language of your choicel(.) yeah/

3 if you want to discuss it in english $\mathrm{xx}$ if you want to: (.)

4 do it in catalan or spanish you can do it as well $\backslash($.) ok/(.) yeah/(.)

As we can observe, the instructor creates 'own language moments' (Kerr, 2019), by explicitly telling students that they can answer the task's questions 
"in any language of [their] choice" (line 2) and that they can also carry out the group discussion in whichever of the three languages they prefer: English, Catalan or Spanish (lines 3-4).

\section{Conclusions}

This chapter has explored teacher's talk in an ESP university classroom in Catalonia, where local students are typically bilingual in Catalan and Spanish. My analysis has been aimed at describing an instructor's personal way of responding to a relatively recent call on foreign language teaching to overcome a policy of language separation and adopt a more cognitively-realistic, contextuallysituated approach to language teaching and learning that integrates the learners' knowledge of and communicative experience in different languages.

In dealing with teaching innovation and, more specifically, with the adoption of a plurilingual perspective in adult foreign language teaching, I have implicitly introduced a sense of complexity which I see as very much in line with Complexity Theory's rejection of the view of complex systems as rulegoverned: "the act of playing the game has a way of changing the rules" (Gleick, 1987: 24; cited in Larsen-Freeman, 2013: 369). I see the analysis that I have presented not only as an attempt to avoid establishing a direct causal relationship between materials design and learning outcomes, but especially as a call to be alert to elements of the teaching and learning process that perhaps cannot be fully anticipated and that have to do with the development of the teacher's personal definition of how to do being a plurilingual teacher.

\section{Acknowledgements}

The research project of which the present study forms has been supported by the research grant FFI2015-67769-P from the Spanish Ministry of Science, Innovation and Competitiveness. The other five participants in this project were Irati Diert, Lídia Gallego-Balsà, Àngels Llanes, Enric Llurda and Xavier Martin; my gratitude to all of them. I am especially grateful to the editors of the volume for their patience, meticulous guidance, comments and suggestions.

\section{References}

Candelier, M., Camilleri Grima, A., Castelloti, V., de Pietro, J.-F., Lörinez, I., Meissner, F.-J., Schroder-Sura, A., \& Noguerol, A. (2007). Framework of references for pluralistic approaches to languages and cultures. Graz: European Centre for Modern Languages, Council of Europe.

Cenoz, J., \& Gorter, D. (2013). Towards a plurilingual approach in English language teaching: Softening the boundaries between languages. TESOL Quarterly, 47(3), 591-599. 
Council of Europe (2001). Common European framework of reference for languages: Learning, teaching, assessment. Strasbourg: Council of Europe Publishing.

Council of Europe (2018). Common European framework of reference for languages: Learning, teaching, assessment - Companion volume. Strasbourg: Council of Europe Publishing.

Creese, A., \& Blackledge, A. (2010). Translanguaging in the bilingual classroom: A pedagogy for learning and teaching. Modern Language Journal, 94, 103-115.

Cummins, J. (2005). Teaching for cross-language transfer in dual language education: Possibilities and pitfalls. Paper presented at TESOL Symposium on Dual Language Education:Teaching and Learning Two Languages in the EFL Setting September 23, 2005 Boğaziçi University Istanbul, Turkey. Retrieved from https://instructor. tesol.org/docs/default-source/new-resource-library/symposium-on-duallanguage-education-3.pdf.

Cummins, J. (2009). Multilingualism in the English-language classroom: Pedagogical Considerations. TESOL Quarterly, 43(2), 317-321.

Duverger, J. 2007. Didactiser l'alternance des langues en cours de DNL [Didacticising language alternation in non-language discipline subjects]. Tréma 28, 81-88. http:// trema.revues.org/302.

Gleick, J. (1987). Chaos. Making a new science. New York:Viking.

Goffman, E. (1981) Forms of talk. Philadelphia: University of Pennsylvania Press.

Hall, G., \& Cook, G. (2012). Own-language use in language teaching and learning. Language Teaching, 45(3), 271-308.

Kerr, P. (2019). The use of L1 in English language teaching. Cambridge: Cambridge University Press. Retrieved from https://languageresearch.cambridge.org/images/ CambridgePapersInELT_UseOfL1_2019_ONLINE.pdf.

Larsen-Freeman, D. (2013) Introduction. Complexity Theory: A new way to think. Revista Brasileira de Linguistica Aplicada, 13(2), 369-373.

Moore, E., Nussbaum, L, \& Borràs, E. (2012). Plurilingual teaching and learning practices in 'internationalised' university lectures. International Journal of Bilingual Education and Bilingualism, 16 (4), 471-493.

Pawley, A. and Syder, F. (1983). Two puzzles for linguistic theory: Native-like selection and native-like fluency. In J. Richards and R. Schmidt (Eds.), Language and communication (pp. 191-226). London: Longman.

van Leeuwen, T. (2007). Legitimation in discourse and communication. Discourse E Communication, 1, 91-112.

Williams, C. (2002). Extending bilingualism in the education system. Education and Lifelong Learning Committee (ELL Report No. 06-2). 


\title{
Plurilingual modes of interaction in English-medium university classes
}

\author{
Eulàlia Borràs and Luci Nussbaum
}

\section{Introduction}

The following chapter examines plurilingual activities in a class taught in English at a public university in Catalonia. The classroom use of English in academic subjects, called English as a Medium of Instruction (EMI), corresponds, according to the language policy documents of the university in this study, to one of the scenarios outlined in the so-called internationalisation of tertiary institutions.

In our data the participants - teacher and students - use English, but they also resort to Catalan for certain practical purposes. This gives rise, in the first place, to contrasts between documented language policies and language policies in practice. Moreover, in this context, it is important to consider the linguistic practices of teachers and their students and how they interact while constructing academic content. Using Conversation Analysis (CA), this chapter explores how language alternations, as well as multimodal embodied resources (gestures, glances and blackboard sketches) favour student participation in knowledge-construction activities.

In the first section of the chapter, we will outline the main approaches that structure this contribution. These are, on the one hand, the teacher's orientation towards the recipient and, on the other, the extensive use of plurilingual and multimodal resources. In the following section, we will present the university class under examination, as well as the procedure used in analysing it. The next section will explore how language alternation and other multimodal resources promote student public participation and the interactive construction of knowledge based on two axes: (1) The control of student understanding of the contents by means of questions from the teacher and the elicited responses from students; and (2) the co-construction of knowledge based on student selfselections and their public contribution to the development of the activity. The text concludes with a discussion of the results of the data analysis. 


\section{Plurilingual interaction in university classes}

In this section we will explore approaches that we consider useful for studying our data. First, we present some aspects of the construction of participation in teacher-fronted university classrooms. Second, we focus on certain contributions to plurilingual practices in classrooms that can offer specific insights for analysing our data.

\section{Students as participants}

Erickson $(1982,2004)$ uses the term 'task learning environment' to refer to the 'academic task structure', understood as the set of restrictions derived from the logic of the content of the academic discipline. From this perspective, the academic task structure organises the order of the actions designed by the teacher. However, the task-learning environment includes the social participation structure, understood as the restrictions regarding the participants' rights and obligations. These concepts are somehow related to what Breen (1989) and Seedhouse (2004) refer to as "task-as-workplan" and "task-in-process". We must also consider that, at certain times, teacher-fronted classes take a lecture format (Young, 1994) with little or no teacher-student interaction; whereas at other times, these classes are characterised by the presence of interactional sequences in the form of IRF (Initiation-Response-Feedback) such as those described by Sinclair and Coulthard (1975) and Mehan (1979), among others.

The footing model deployed by Goffman (1981) shows the different ways in which speakers configure themselves in speech and configure the status of their interlocutors as well, just as teachers do in their classes. Despite its heuristic value, the model was criticised because speaker and listener are considered separate entities. Instead, Goodwin and Goodwin consider both speaker and hearer as social actors who are taken into consideration not only through speech but also through gestures, gaze, and body position (Goodwin and Goodwin, 2004). This approach fits with the notion of recipient design, key in CA and considered by Sacks, Schegloff, and Jefferson (1974) as the general principle of talk-in-interaction. Recipient design may be defined as the ways in which the person making an utterance shows orientation towards the other participants in a specific local and situated interaction. This is related to the principle by which speech is sensitive to context while constantly renewing it. In this sense, we also find useful the notion of environmentally coupled gestures (Goodwin, 2007), which make reference to gesturing (in our case the teacher pointing to the board) as a way to tie language to specific phenomena in the environment. The progress of the class is built around different kinds of semiotic resources, which all make a distinct contribution to the intelligibility and organisation of the action in progress. We understand that these diverse notions are relevant to our analysis in that they help us identify the multiple ways in which the teacher addresses the students as participants in the interactive event of teaching. 
Greiffenhagen (2008), in analysing courses at the university, relates the orientation towards the recipient with the retrospective and prospective organisation of teaching talk. Likewise, Young (1994) and Veronesi (2007, 2009) describe teaching procedures for facilitating the content of the classes by resorting to examples, rhetorical questions and discourse markers of different order. Borràs et al. (2012) show that the orientation towards students in monologue sequences is carried out as well through reformulations, multimodal resources (including body movements, gaze, pointing towards certain elements on the blackboard) and alternating languages. In this vein, Mülher et al. (2012) and Gajo et al. (2013) show the close relationship between the participation format and the linguistic format. By participation format they refer to whether the class is mono-managed by the teacher in master class formats or whether it is poly-managed in formats of verbal interaction between teacher and students. By linguistic format they refer to whether the class is displayed in unilingual mode - one language only - or in plurilingual mode (Lüdi and Py, 2003). We will comment on these aspects in the following section.

\section{Plurilingualism in academic knowledge construction}

Our study draws on the conceptualisation of plurilingualism as the use of several languages in the same interactional event and relates it to the deployment of plurilingual repertoires (Lüdi and Py, 2009). As we are interested in exploring the plurilingual practices in teacher-fronted EMI classes, we will examine the language alternations present in the teacher-student interactions to determine how the use of several languages in the class (understood as an interactive event, as described earlier) may have an impact on the construction of knowledge.

In fact, there is a large body of research on plurilingual practices in which languages are taught. Ustunel and Seedhouse (2005) point out that these uses are related to facilitating access to the subject matter, that is, as a procedure to help students understand the discipline; to manage classroom discourse; and to promote interpersonal relationships in the classroom. Likewise, Musk and Cromdal (2018) in their overview on empirical studies in educational contexts that follow CA guidelines indicate that language alternations are related - not exclusively but sometimes in combination - with doing bilingual identity, signalling alignment and disalignment in the classroom, organising educational tasks, doing language policy, and determining the medium of interaction in classroom interaction.

From this set of diverse foci, signalling alignment and disalignment in the classroom, doing language policy, and determining the medium of interaction seem relevant to our analysis. In our data, there are times in which the teacher alternates from English (medium of instruction) to Catalan in a switch both discourse-related and participant-related (Auer, 1988; Nussbaum, 1992), in effect turning both Catalan and English into the medium of interaction (Bonacina and Gafaranga, 2011) and practicing a de facto bilingual policy 
(Bonacina-Pugh, 2012). Students often align with the language of the teacher's previous turn, but not always.

Certainly, plurilingual practices can also be resources for accessing curricular content in classes using an L2 as a medium of instruction. In this sense, the interactionist approaches to situated cognition, which are based on perspectives from ethnomethodology, from CA, and from socio-constructivist perspectives (Mondada and Pekarek Doehler, 2004) seem complementary to study the role of plurilingual resources in the construction of knowledge. The works on the impact of plurilingual resources in the construction of academic knowledge in classes in which an L2 is used -still scarce (see Moschkovich, 2002; Barwell, 2003, 2005; Pitsch, 2005; Gajo, 2007; Moore and Nussbaum, 2011) - show that language alternation is a useful resource for learning academic content. For Gajo (2007), classroom interaction constitutes an instrument of mediation between teacher and students. Given the lack of competence in L2 to understand the academic content, plurilingual uses are 're-mediation' procedures that can help achieve a certain degree of saturation, that is, apprehension of the complexity of the knowledge being dealt with (Gajo, 2007; Gajo and Grobet, 2008).

We will pay close attention to these phenomena in our analysis to try to identify the language dynamics of the teacher-fronted interactions in EMI classes in relation with the construction of knowledge.

\section{Methodology}

The data presented in this chapter were collected at a public technical university in Catalonia in which two languages - Catalan and Spanish - are co-official. The creation of the European Higher Education Area and the dynamics of internationalisation of universities, with the consequent teacher and student exchanges resulting from the internationalisation-at-home policies (Nilsson, 2003) are the main reasons for encouraging language policies that favour the use of English and, specifically, teaching in this language (Moore and Nussbaum, 2014).

The excerpts below were collected in 2010 and comprise a set of two sessions of an information technology class scheduled to be taught in English and attended exclusively by local students. The teacher is a computer scientist who had recently been on an extensive postdoc stay in a US public university. The students are 18 second-year chemical engineering pupils who are actively taking notes while the teacher sketches out the topic of binary codes on the blackboard in an interactive teacher-fronted class. The data were accompanied by field notes and transcribed using ELAN following the Jefferson (2004) conventions in what was an action research study. These fragments were discussed in data sessions within the GREIP group and in the DYLAN project (Nussbaum, Moore, and Borràs, 2013).

Drawing on the described theoretical framework and using CA, we want to explore the interactive construction of knowledge, focusing on the way the 
teacher uses linguistic and multimodal resources to invite the public participation of students and how these contribute to the development of the situated teaching practices.

\section{Plurilingual practices in knowledge construction}

We will present two fragments to discuss the plurilingual practices of a teacherfronted class in an EMI environment. We understand these classes as interactive events in which the teacher adapts talk to the characteristics of the recipient in what we understand as 'recipient design' organisation. When the teacher designs the interaction taking the recipient into consideration this includes, of course, the language in which the speaker chooses to address them. This has ethnomethodological implications regarding categorisations (Sacks, 1972, 1992) and the identifiable traits attributed to the interlocutors. Talk-in-interaction focuses on the sequential organisation of conversation, including how the understanding of an utterance is revealed through a subsequent response to it. That is why we want to analyse the sequentiality of the teacher-student conversation turns in relation to the language alternation being observed in the concurrent organisation of action. We will also pay close attention to the emergent local configurations embodied in the environmentally-coupled gestures (Goodwin, 2007) by the teacher when sketching out numbers on the board.

In the two excerpts below, we will analyse the language alternations with respect to the joint construction of knowledge by both teacher and students. In excerpt 1 the teacher is calling the students' attention to a specific piece of content he has just sketched out on the board. The focalisation of the public attention on this content is essential to jointly identify elements of special difficulty or of vital importance to follow the lecturer's argument. We want to understand if language alternation may play a role in getting the attention of students and their public participation in these crucial moments of situated interaction.

Excerpt 1. Participants: Teacher (Taronger, TAR), Students (ST1, ST2)
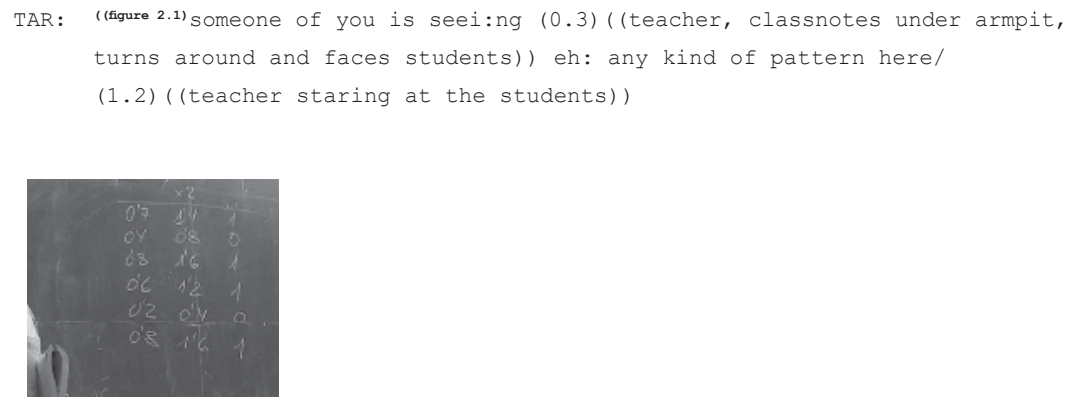

Figure 2.1 
4 in that methodology/(0.7)

5 algú de vosaltres veu_(0.1) e:I_(0.3) ((slightly moves and gazes at students)) can anyone see

6 alguna cosa que es repeteix/

anything repeating here/

7 ST2: (0.9) la seqüèncial no/ $(0.2)$

the sequence \right/

u zero u/ (0.1) u zero u\ (1.1) ${ }^{\circ}$ no $/(0.9)$

one zero one/ $(0.1)$ one zero onel (1.1) ${ }^{\circ} \mathrm{no}^{\circ} /(0.9$

9 TAR: exactly $\backslash(0.1)$ because_ (0.2) ((figure 2.2))here_ $(0.1)$

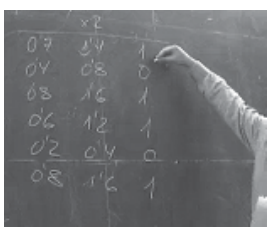

Figure 2.2

10 you have $a: h$ at that point o:f- (0.9)
11 let me see\ (1.2)
12 with that point of ((figure 2.3)) here\(1.8)

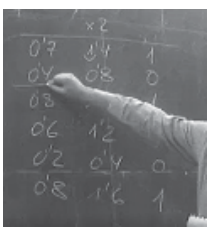

Figure 2.3

$13{ }^{\circ}$ (now?) zero dos no $\backslash^{\circ}(0.1)$ ( (stops writing on board))

two nol

14 ST2: a l'última\ l'última $t^{\prime}$ has equivocat $(0.1)$

on the last one \you made a mistake\}

15 TAR: $\mathbf{m}^{\prime}$ he equi[vocat)] ((looks at board trying to figure out where the mistake is))

I made a mistake)

16 ST1: [zero] [quatre\]

zero four

17 ST2:

[hi ha] un zero quatre al començamentl (0.9)

there is a zero four at the beginning $\backslash$

18 TAR: zero quatrel teniu raó (1.9)

zero four $\backslash$ you are right)

((erases board 0.8, writes 0.4, erases board 1.6, writes 0.8)) 
The teacher, after his presentation in English accompanied by inscriptions on the board, asks the students a question: "someone of you is seeing any kind of pattern here/". After a pause with no answer, in line 4, he specifies his question, "in that methodology $\ "$, continuing in English. Then, again in the absence of an answer, he reformulates the question in a simplified way and in Catalan ("alguna cosa que es repeteix" instead of "any kind of pattern in that methodology"). So, he does two things to increase student participation: he codeswitches, and he reformulates by paraphrasing. A student proposes an answer in Catalan in lines 7 and 8 that is accepted by the teacher, who now returns to English, while closing the sequence ("exactly", in line 9). It seems that the reformulation of the question in Catalan provides more time for thinking about the answer and allows the student to align with the language chosen by the teacher, but not to the medium of instruction according to policy.

In the following turns, when the teacher, again in English, tries to elaborate on the student's answer in lines 9-10, he realises that something is wrong with the numbers on the board in lines 10-13 and seems to be sliding towards Catalan in "zero dos". Again, ST2 participates in Catalan by self-selecting in line 14 to indicate that there is a mistake in the mathematical pattern the teacher set out on the board. The teacher confirms repeating in first person what ST2 has said ("m'he equivocat"); while overlapping, ST1 and then ST2 indicate the point of the error. The teacher continues in Catalan, correcting his mistake on the board and confirming he was wrong in line 18. He then self corrects uttering a self-repair in English and closes the sequence. It seems, then, that the use of Catalan as a medium of interaction, beyond being a way to manage local contingencies, favours the construction of knowledge both when the teacher hetero-selects the students (lines 1-6), and when any of them selfselects (lines 14, 16, 17).

The teacher follows the language policy save when he wants to increase student participation. For example, after waiting for two silent turns, he codeswitches to Catalan and consequently garners more participation. He also codeswitches when he confirms he has made a mistake. In that case he aligns with the previous student turn. In general, though, the teacher sticks to the EMI policy. In this fragment we have observed that student self-selections are in Catalan. However, we could also argue they align to the language in the previous turn. The data then suggest that there is a preference by the students to participate in Catalan either as a response to a question by the teacher or when self-selecting. Thus, as other studies (see Ustunel and Seedhouse, 2005) demonstrate, the use of the local language elicits and encourages student participation. The alignment of students with the language used by the teacher in the previous turn is a recurring phenomenon in other cases when the language is Catalan, but not always when the previous turn is in English, as we will see in excerpt 2.

We now want to explore in more depth the type of participation format deployed by the students. The data show that the use of English usually 
correlates with English use in the teacher's previous turn and with very short utterances, very often related to simple numbers. Also, students seem to display more elaborate responses when they respond in Catalan. This phenomenon is observed in fragment 2 when the student initially participates in English but switches to Catalan. The following fragment illustrates a case of affiliation and disaffiliation towards the language displayed by the teacher in the previous turn. Before the start of the excerpt, the teacher has been sketching out content on the binary code on the blackboard, thus making relevant the public configuration of resources.

Excerpt 2. Participants: Teacher (Taronger, TAR), Students (ST1, ST2)

1 TAR: ((figure 2.4)) we have here a little problem \(1.5)((writing on the board))

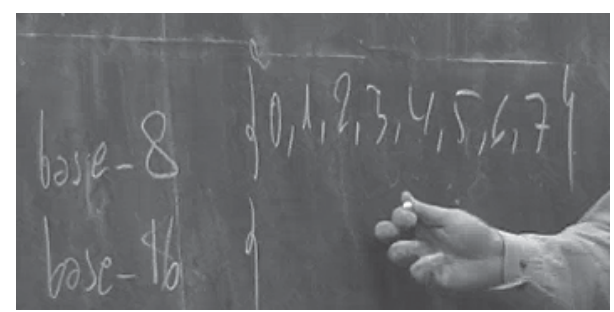

Figure 2.4

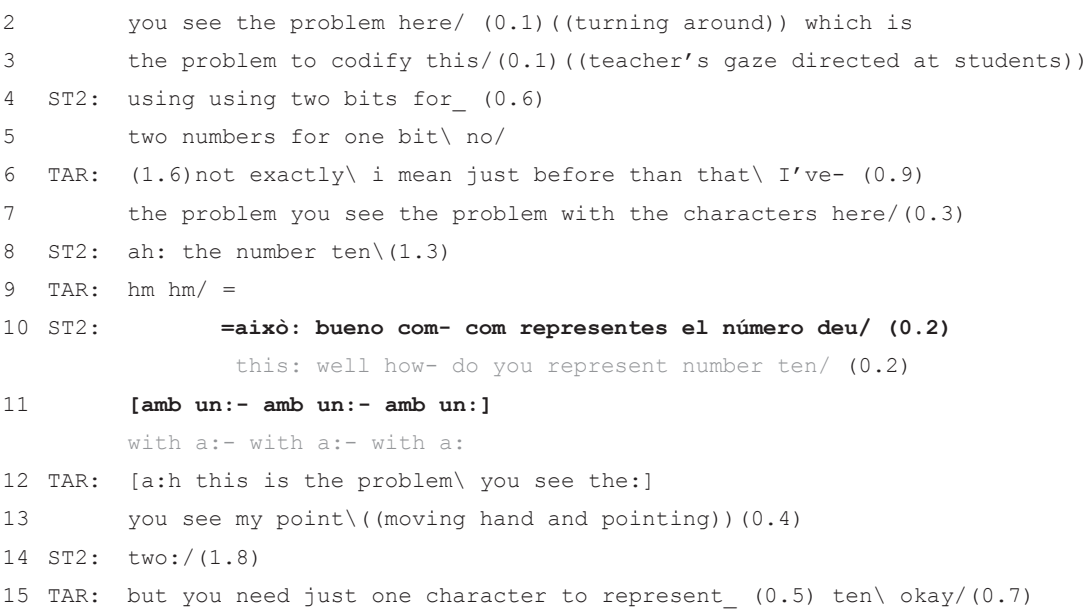

TAR asks a question in English in lines 1-3. ST2 responds in English in lines 4-5. But TAR does not consider the answer satisfactory - "not exactly" - displaying an evaluative stance, and reformulates his question in lines $6-7$, pointing to the numbers on the board. The same student answers, after an exclamation, as indicating that he has grasped the problem. On the next turn, 
the teacher's "hm hm", with an ascending intonation, prompts the student to elaborate his answer. The student switches to Catalan by proposing a question in line 10 and trying to answer the question in line 11. The teacher makes an utterance by overlap, in English, insisting that there is a relevant problem to grasp the logic of the question, in line 12 . Then the interaction continues in English.

The possibility of using Catalan, either aligning with the language used by the teacher in the previous turn (excerpt 1), or disaligning (excerpt 2) seems to encourage student participation. This participation allows the teacher to meet his objectives regarding the development of the task-as-workplan (Breen, 1989). The data thus seem to suggest that language alternations would enable reaching a saturation point (Gajo, 2007) for the academic content.

\section{Conclusions}

This chapter has analysed two situated practices in an EMI university class in which plurilingual uses, specifically language alternations associated with other semiotic resources, including gaze, body language and sketches on the board, emerge to ensure the participation of students in the construction of the academic task. The orientation of the teacher towards his students consists in eliciting their public participation based on Initiation-Response-Feedback questions (Sinclair and Coulthard, 1975; Mehan, 1979). This enables the instructor to check understanding of the subject matter, discover mistakes, and create learning opportunities (Erickson, 1982). The analysis of the two excerpts suggests that students participate more strongly when they adopt Catalan, regardless of whether they are aligning or disaligning from the language used by the teacher in the previous turn.

It is important to point out that the teacher does not always orchestrate the languages being mobilised in class in the data analysed. In this regard, we have observed cases of self-selection by students in excerpt 1 carried out in Catalan. It seems, therefore, that the most elaborate forms of student participation, both in terms of initiative (self-selection) and in terms of content development (unsolicited observations and questions), are produced in Catalan. The data then seem to suggest that the English-Catalan medium of interaction allows students to participate in the development of content, which the teacher essentially proposes in English as a medium of instruction. This leads us to sustain that the practised language policy is, de facto, bilingual.

Finally, it should be noted that the linguistic resources being mobilised by the teacher are never explicitly marked in our corpus. In this sense, in the data analysed, language alternation is not announced by connectors indicating its presence. It occurs in specific sequential positions marked out by other multimodal resources, such as pauses, changes in body position and gaze. This suggests that neither teachers nor students are particularly concerned with learning forms, but rather focus on the construction of academic knowledge. 
The integration of L2 and academic content occurs in the on-going practical actions that give rise to the emergence of plurilingual modes of interaction. Language alternation thus proves to be an important resource for accessing knowledge at specific times in which its transmission or construction becomes problematic.

\section{References}

Auer, P. (1988). A conversation analytic approach to code-switching and transfer. In. M. Heller (Ed.), Codeswitching (pp. 187-213). Berlin: Mouton de Gruyter.

Barwell, R. (2003). Patterns of attention in the interaction of a primary school mathematics student with English as an additional language. Educational Studies in Mathematics, 53(1), 35-59.

Barwell, R. (2005). Integrating language and content: Issues from the mathematics classroom. Linguistics and Education, 16, 205-218.

Bonacina-Pugh, F. (2012). Researching 'practiced language policies': Insights from Conversation Analysis. Language Policy, 11, 213-234.

Bonacina, F., \& Gafaranga, J. (2011). 'Medium of instruction' vs. 'medium of classroom interaction': Language choice in a French complementary school classroom in Scotland. International Journal of Bilingual Education and Bilingualism, 14 (3), 319-334.

Borràs, E., Moore, E., Nussbaum, L., \& Patiño, A. (2012). Emergence de modes plurilingues dans des cours universitaires en L2. In L. Mondada \& L. Nussbaum (Eds.), Interactions cosmopolites: L'organisation de la participation plurilingue (pp.63-98). Limoges: Editions Lambert Lucas.

Breen, M. (1989).The evaluation cycle for language learning tasks. In R. K.Johnson (Ed.), The second language curriculum (pp. 187-206). Cambridge: Cambridge University Press.

Erickson, F. (1982). Classroom discourse as improvisation: Relationships between academic task structure and social participation structure in lessons. In L. C. Wilkinson (Ed.), Communicating in the classroom (pp. 153-181). New York: Academic Press.

Erickson, F. (2004). Talk and Social Theory: Ecologies of Speaking and Listening in Everyday Life. Cambridge: Polity Press.

Gajo, L. (2007). Knowledge and subject knowledge: How does bilingualism contribute to subject development? International Journal on Bilingual Education and Bilingualism, $10(5), 563-581$.

Gajo, L., \& Grobet, A. (2008). Interagir en langue étrangère dans le cadre de disciplines scolaires: Intégration et saturation des savoirs disciplinaires et linguistiques dans l'élaboration des definitions. In L. Filliettaz \& M.-L. Schubauer-Leoni (Eds.), Processus interactionnels et situations éducatives (pp. 113-136). Brussels: De Boeck.

Gajo, L., Grobet, A., Serra, C., Steffen, G., \& Berthoud, A. C. (2013). Plurilingualism and knowledge construction in higher education. In A. C. Berthoud, F. Grin \& G. Lüdi (Eds.), Exploring the dynamics of multilingualism: The DYLAN project (pp. 279-298). Amsterdam: John Benjamins.

Goffman, E. (1981). Forms of talk. Philadelphia: University of Philadelphia Press.

Goodwin, C. (2007). Participation, stance and affect in the organization of activities. Discourse \& Society, 28, 53-73.

Goodwin, C., \& Goodwin, M. H. (2004). Participation. In A. Duranti (Ed.), A companion to linguistic anthropology (pp. 222-244). Oxford: Basil Blackwell. 
Greiffenhagen, C. (2008).Video analysis of mathematical practice? Different attempts to "open up" mathematics for sociological investigation. Forum Qualitative Sozialforschung / Forum: Qualitative Social Research,9(3),Art. 32. Retrieved from http://nbn-resolving. de/urn:nbn:de:0114-fqs0803323.

Jefferson, G. (2004). Glossary of transcript symbols with an introduction. In G. H. Lerner (Ed.), Conversation Analysis: Studies from the first generation (pp. 13-31). Amsterdam/ Philadelphia, PN: John Benjamins.

Lüdi, G., \& Py, B. (2003). Etre bilingue. Bern: Peter Lang.

Lüdi, G., \& Py, B. (2009). To be or not to be... a plurilingual speaker. International Journal of Multilingualism, 6 (2), 154-167.

Mehan, H. (1979). Learning lessons. Social organization in the classroom. Cambridge, MA: Harvard University Press.

Mondada, L., \& Pekarek Doehler, S. (2004). Second language acquisition as situated practice:Task accomplishment in the French second language classroom. The Modern Language Journal, 88(4), 501-518.

Moore, E., \& Nussbaum, L. (2011). Què aporta l'anàlisi conversacional a la comprensió de les situacions d'AICLE. In C. Escobar \& L. Nussbaum (Eds.), Aprendre en una altra llengua / Learning through another language / Aprender en otra lengua. Bellaterra: Servei de publicacions de la UAB.

Moore, E., \& Nussbaum, L. (2014). Building a multilingual university in institutional policies and everyday practices. In J. W. Unger, M. Krzyżanowski, \& R. Wodak (Eds.), Multilingual encounters in Europe's institutional spaces (pp. 243-269). London: Continuum.

Moschkovich, J. (2002). A situated and sociocultural perspective on bilingual mathematics learners. Mathematical Thinking and Learning, 4 (2\&3), 189-212.

Mülher, M., Gajo, L., Berthoud, A-C., Grobet, A., \& Steffen, G. (2012). Participation, ressources plurilingues et élaboration des connaissances dans l'enseignement supérieur. In L. Mondada \& L. Nussbaum (Eds.), Interactions cosmopolites: L'organisation de la participation plurilingue (pp.193-224). Limoges: Editions Lambert Lucas.

Musk N., \& Cromdal J. (2018). Analysing bilingual talk. Conversation analysis and language alternation. In A. Filipi \& N. Markee (Eds.), Conversation analysis and language alternation. Capturing transitions in the classroom (pp. 15-34). Amsterdam: John Benjamins.

Nilsson, B. (2003). Internationalisation at home from a Swedish perspective:The case of Mälmo. Journal of Studies in International Education, 7, 27-40.

Nussbaum, L. (1992). El contacte de llengües en la interlocució. Treballs de Sociolingüística Catalana, 10, 99-123.

Nussbaum, L., Moore, E., \& Borràs, E. (2013). Accomplishing multilingualim through plurilingual activities. In A. C. Berthoud, F. Grin, \& G. Lüdi (Eds.), Exploring the dynamics of multilingualism: The DYLAN project (pp. 229-252). Amsterdam: John Benjamins.

Pitsch, K. (2005). Interaction, auto-organisation et pratiques d'inscription. Appropriation lexicale en classes bilingües. Aile, 73-99.

Sacks, H. (1972). An initial investigation of the usability of conversational data for doing sociology. In D. Sudnow (Ed.), Studies in social interaction (pp. 31-74). New York: Free Press.

Sacks, H. (1992). Lectures on conversation. Edited by G. Jefferson. Cambridge (MA): Blackwell Publishers. 
Sacks, H., Schegloff, E. A., \& Jefferson, G. (1974). A simplest systematics for the organization of turn-taking for conversation. Language, 50(4), 696-735.

Seedhouse, P. (2004). The interactional architecture of the language classroom: A conversation analysis perspective. Malden, MA: Blackwell.

Sinclair, J., \& Coulthard, M. (1975). Towards an analysis of discourse: the English used by teachers and pupils. Oxford: Oxford University Press.

Ustunel, E., \& Seedhouse, P. (2005). Why that, in that language, right now? Codeswitching and pedagogical focus. International Journal of Applied Linguistics, 15(3), 302-325.

Veronesi,D. (2007). Movimento nello spazio, prossemica e risorse interazionali:Un'analisi preliminare del rapporto tra modalità in contesti didattici accademici. Bulletin Suisse de Linguistique Appliquée, 85, 107-130.

Veronesi, D. (2009). La lezione accademica in contesto plurilingue: Prospettive di analisi tra parlato monologico e interazione plurilocutoria. In D. Veronesi \& C. Nickenig (Eds.), Bi- and multilingual universities: European perspectives and beyond (pp. 205-228). Bozen-Bolzano: Bozen-Bolzano University Press.

Young, L. (1994). University lectures - macro-structure and micro-features. In J. Flowerdew (Ed.), Academic listening: Research perspectives (pp.159-176). Cambridge: Cambridge University Press. 


\title{
Creating a plurilingual space through talk-in-interaction
}

\author{
Dolors Masats and Artur Noguerol
}

\section{Introduction}

In the late 1950s British scholars of the so-called Language Awareness movement supported the idea that school curricula should foster explicit reflection on the nature and functions of language(s) as a means to favour the development of learners' metalinguistic competence (Hawkins, 1984). Such viewpoint was not widely accepted until a few decades later, when the conclusions of a symposia held by the Council for Cultural Cooperation (CCC) to promote understanding on educational and cultural matters between the members of the Council of Europe supported the acceptance that the observation of languages would enable learners to construct linguistic and cultural knowledge and to overcome misconceptions about language and learning (Committee for General and Technical Education, 1973). At the turn of the century, several members of the Research Centre for Plurilingual Education \& Interaction (GREIP) took part in various European projects based on this premise, which resulted in the development of a pluralistic approach to languages and cultures known as 'éveil aux langues' (Candelier, 1998; Noguerol, 2000; Masats, 2001). The proposal was constructed upon the belief that in order to contribute to 'opening up classrooms to linguistic and cultural diversity' (Perregaux, 1995) teachers should create multilingual spaces, that is, opportunities for learners to 'awaken to languages' (Candelier, 2003a, 2003b), to embrace all the languages and varieties in their repertoires - regardless whether they were taught at school or not - and to appreciate the value of plurilingual practices as a procedure to construct knowledge (de Goumoëns et al, 2013).

In this chapter we want to examine the development of a class activity proposed by two primary teachers who opened up their classrooms to linguistic and cultural diversity and invited a mother of one of their students to tell a story in Moroccan Arabic. Our analysis will focus on how participants create a plurilingual space while they negotiate and enact the norms of language use they co-construct while they manage and conduct the activity at hand. Before presenting the analysis of our data, we will briefly relate current language policies in compulsory education in Catalonia and review the literature 
that allows us to understand and analyse plurilingual talk in schools and society. The chapter will end with some concluding remarks on our findings.

\section{Plurilingual education and practice}

Global migration movements at the turn of the century altered the linguistic landscapes of schools and societies worldwide and resulted in a renewed interest in a more holistic view of languages that triggered the need to promote plurilingual education. Today plurilingual education is at the root of European educational guidelines, such as those proposed in the Common European Framework of Reference for Languages (CEFR, Council of Europe, 2001, 2018), as well as in the latest language policy documents in Catalonia. In this sense, the language model of the Catalan educational system (Departament d'Ensenyament, 2018: 6) establishes:

the mastery of linguistic and communicative competence [is] constructed on the basis of interrelations and interaction between different languages [...] (and) that all languages, both curricular and native, contribute to the development of each student's communicative skills, meaning that they can use them to gain knowledge and achieve effective communication in different languages as well as in different situations and circumstances.

As stated in the introduction to this volume, Catalan (and Occitan in Aran, in northwestern Catalonia) are the "official languages of reference and the languages normally used in the instructional, administrative and communicative fields, and form the cornerstone of a plurilingual education project" (Departament d'Ensenyament, 2018: 14); Spanish and one (or two) foreign languages are also part of the curriculum as objects or vehicles of instruction. Finally, the languages of students "play a role of integration and equality by raising awareness, respect, recognition, and openness toward the learning of all languages" (Departament d'Ensenyament, 2018: 14) and occasionally can be studied as optional (non-)curricular subjects.

Plurilingual education is sustained in the principle that "teaching languages means helping pupils to develop a plurilingual repertoire, a repertoire that includes practices as well as representations" (Castellotti and Moore, 2002: 21). Opening up classrooms to a variety of languages means enacting some sort of language policy that reveals how languages are represented and (re)configured in the speakers' social ideal. Spolsky (2004: 217) argued that language policy

may be discovered in the linguistic behaviour (language practices) of the individual or group. It may also be discovered in the ideology or beliefs about language of the individual or group. Finally, it may be made explicit in the formal language management or planning decisions of an authorised body. 
That is, according to the author, language policy relates to (1) 'language management' actions as identified in texts and discourses, (2) speakers 'beliefs' and ideologies related to the values assigned to language varieties and features and (3) 'practice' or actual linguistic behaviours displayed in talk-in-interaction. Bonacina-Pugh (2012) coined the term 'practiced language policy' to refer to Spolsky's idea that "there is a policy within practices." Thus, 'practiced language policy' relates to the idea that speakers in talk-in-interaction orient to interactional norms they have deduced from their observation of language practices or they have co-constructed with other interactants. The author suggests that the role of the analyst is to unveil these norms and make them explicit. Among the norms employed by speakers who orient to plurilingual talk we find those regulating language alternation, or "the alternating use of more than one language in the same episode of talk" (Musk and Cromdal, 2018: 16).

Code-switching and language selection are resources that allow participants in a communicative event to create the 'practical status' (Unamuno, 2015) of the languages they use to interact and to co-construct their 'practiced language policy'. Following Gumperz's work, Auer $(1984,1998)$ argues that the sequential development of what he calls 'bilingual conversation' (here plurilingual talk) relies on two kind of language alternation ends. The first one is a 'discourse-related' activity employed by a speaker as a 'contextualisation cue' (Gumperz, 1982) to signal the other interactants a change of orientation in the discursive activity at hand. The second one is a 'participant-related' resource that indexes speakers' preference for a particular language or 'medium' (Gafaranga, 1999), either because they or other interactants lack competence, enact a particular identity or display their 'affiliation to the educational institution' (Cots and Nussbaum, 2008) by accommodating to the norms of language use present at schools.

To contextualise our data, we need to relate to previous studies that described the complex dynamics of language alternation in Catalonia. Woolard (1989, 2016) observed that people who opt to refer to their interactants in Catalan (ingroup norm) generally switch into Spanish (accommodation norm) if the response is offered in this language and then proceed in Spanish only (monolingual norm) or combine the use of both languages (bilingual norm). The accommodation norm also prevails in the language choices of students during leisure time at school (Vila and Vial, 2000; Galindo, 2008) and has not been altered by the presence of students of immigrant origin in Catalan schools (Vila, Siqués, and Oller, 2009). Studies conducted by several GREIP members (see, among others, Masats, Nussbaum, and Unamuno, 2007; Nussbaum and Unamuno, 2006; Unamuno, this volume) have illustrated that in the Catalan and English classrooms the medium of instruction and the medium of communication do not always coincide. Broadly speaking, learners conduct the tasks in the target language, but typically address their teachers in Catalan and their peers in Spanish to socialise, manage the task or solve communication problems. This does not occur in the Spanish lessons, where students tend to orient towards a monolingual norm (Spanish only). 
In classrooms such as the one in our study, in which teachers want to create a plurilingual space open to the array of languages and cultures present in the students' repertoires, unveiling speakers' norms of language selection and language alternation becomes necessary to understand 'practiced language policy'.

\section{Methodology}

The data we present here illustrates a communicative event that took place in the late 2010s in a primary school sited in the city of Barcelona. Every year the school takes part in a national school musical festival, Cantania, in which organisers propose the participating schools a collection of songs they will perform together. That year the songs revolved around terror stories. Two fourth grade teachers from one of the schools participating in this music festival prepared a series of activities to get the children in their groups become familiar with the topic of Catania and to encourage them to narrate terror stories. GREIP members took part in the experience and engaged the groups in an Erasmus + KA2 project (ref. 2015-1-ES01-KA203-016127) consisting in exchanging plurilingual and pluricultural experiences with children from other schools in Europe (see Vallejo and Noguerol, 2018). In this context, some children presented a few Arabian tales and, as most students seemed to be interested in the proposal, the two teachers decided to invite the mother of one of them to the school to tell a horror story.

The sequence we will analyse here takes places on the day the mother visited the school. The whole interaction lasts for about 45 minutes and was videorecorded and transcribed by one of the researchers who co-authors this chapter. As we cannot provide the transcription of the full length of the sequence, we have selected several excerpts in which participants engage in activities of language negotiation, language alternation and negotiation of meaning. When the activity starts, the two groups of ten-year-old children are sitting on the floor or on chairs forming a U-shape ready to listen to the story of Sulaymān. The mother sits at the front, on a chair facing the students, and in her hands she holds a text - written in Catalan - with the story she has selected for the occasion (see Figure 3.1). The two teachers sit at the back and the researcher holds the camera and is off screen.

The data we present here is particularly interesting because the classroom activity is led by a person, a mother, who does not form part of the group and who attempts to develop it in a language she does not master (Catalan) while is invited to do it in Moroccan Arabic, the family language of some students in the group. We will examine participants' co-construction of the 'practiced language policy' of this event. Our analysis will focus on how language alternation develops sequentially as the interaction unfolds, revealing the norms of language choice participants (teachers, students and the mother) affiliate with and how they rely to plurilingual talk to convey and construct meaning. 


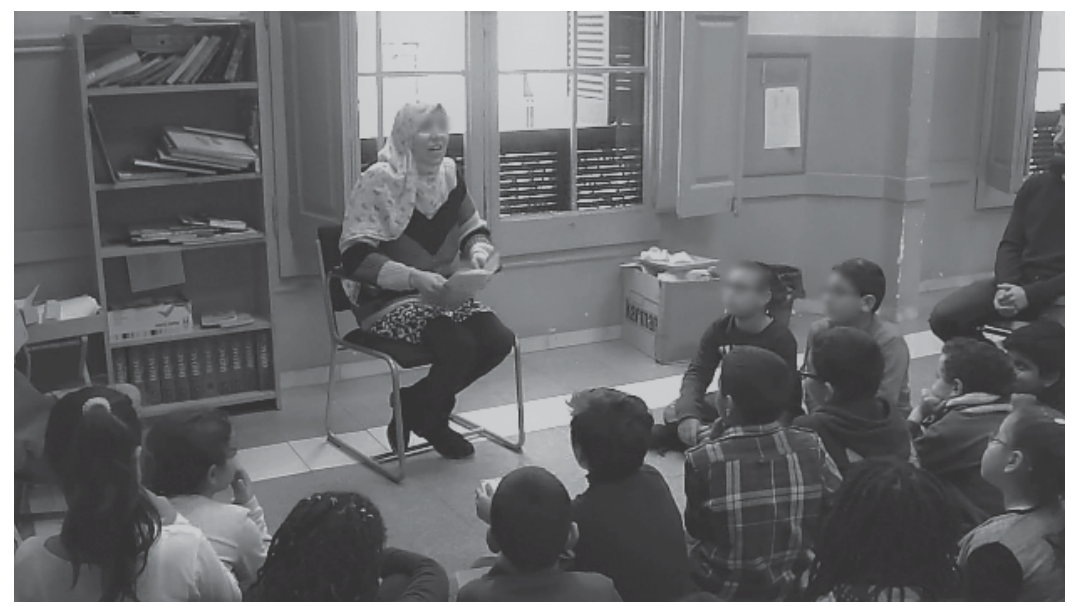

Figure 3.I Seating arrangement

\section{Enacting diversity}

Excerpt 1 starts when one of the teachers invites the mother to tell the story in Arabic. She speaks Darija, a form of vernacular Arabic spoken in Morocco, but has already informed she has prepared the story in Catalan, a language she does not master.

Excerpt 1. Participants: The mother (MOT), two teachers (TE1 \& TE2) and some students, including Alex (ALE), Adib (ADI), student 1 (ST1), student 2 (ST2, students in choral voice (STS) and unidentified speakers (PPP)

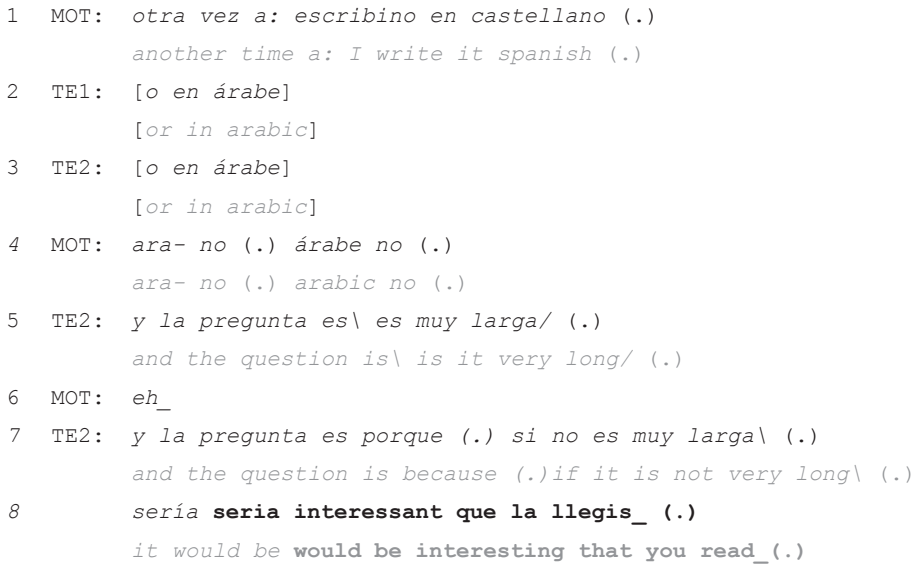


$9 \quad$ la contessis en àrab i en català (.)

you told it in arabic and in catalan(.)

10 MOT: mmm en CATALÁ:N/ no en: l'origen (.)

mmm in CATALA:N/ no in: the origin (.)

11 TE1: sí en árabe (.)

yes in arabic (.)

12 MOT: no (.) en ÁRABE/ (.)

no (.) in ARABIC/ (.)

13 PPP: sí (.)

yes (.)

14 TE2: [hi ha molts que ho saben hi ha molts que $x x$ ]

[there are a lot who know a lot who $\mathrm{xxx}$ ]

15 STs: [sí (.) sí (.)sí XX hay muy pocos XX]

[yes (.) yes (.) yes xxx there are few $x x$ ]

((children are very noisy and FTE interrupts the conversation to take control of the situation))

16 TE2: yo te animaría a explicarla (.) primer en àrab perquè els que

I would encourage you to tell it (.)first in arabic so that those who

17 t'entenguin ho puguin captar (.)i després el contem en castellà (.)

can understand you could grasp it (.) and then we tell it in Spanish (.)

[perquè després $\mathrm{xx}$ ]

[because after $\mathrm{xxx}$ ]

19 TE1: [en català] en català porque lo [tienes en català]

[in catalan] in catalan because you [have it in catalan]

20 TE2: [en català en català (.) en català sí perdona]

[in catalan in catalan(.) in catalan yes sorry]

21 TE1: sí, pero estaría bien que primero (.)

yes, but it would be nice that first (.)

mira nois (.) us he demanat des del començament que calleu\(.)

come on boys (.) I have asked you from the start to be quiet\ (.)

23 TE2: ((directs gaze to the students the female teacher has scolded))

24 TE2: adib

25 ADI: es que me dise que lo traduscal (.)

hmm he asks me to translate it for him (.)

26 TE2: ((signals Adib to approach)) vinel.. m'ho traduiràs a mi $\backslash$ (.)

come $\backslash$. you will translate it for me $($.)

27 ALE: es que xxx que quiero que me lo traduzque (.)

hmm xxx I want him to translate it for me (.)

28 TE2: que $t^{\prime}$ ho tradueixi $\backslash($.$) vine (.) ( (again signals Adid to approach))$

that he translates it for youl (.) come (.)

29 TE1: que si lo quieres explicar primero en árabe (.) porque habrá

that if you want to tell it first in arabic (.) because there would be muchos que lo entiendan (.) y después lo lees en catalán para many who would understand it (.) and then you read it in catalan for 


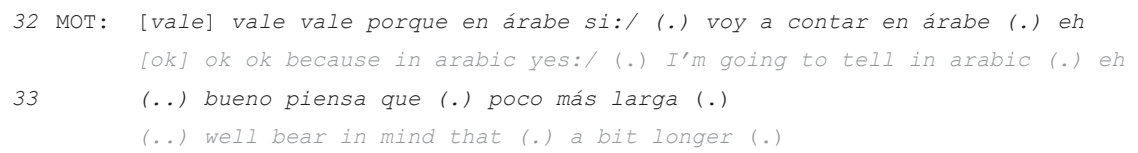

Before the excerpt starts the mother has informed the two teachers that she has the text written down in Catalan, but if she had to do it again, she would write the story in Spanish (line 1). The two teachers reply that she could do it in Arabic (lines 2-3), which she does not accept (line 4). This short exchange triggers a discussion, which reveals the agenda of the participants and how they attempt to construct the 'practiced language policy' for this particular event.

First, we can observe that the mother perceives the language policy of the school does not legitimise the use of Arabic to tell the story and refuses to do so (lines 4,12 ). On doing so, she is indexing that she attributes to Catalan the 'status of legitimate language' to carry out a pedagogical activity. This is clearly shown in line 10, when she hesitates and then produces the word 'Catalan' in a loud voice and rising intonation in opposition to the normal tone she uses when she refers to Arabic as 'the original' language of the story. Her affiliation to Catalan as the 'institutional language' contradicts the agenda of the two teachers who want to construct a plurilingual space in which heritage languages are accepted, in line with the language policy as described in the Catalan curriculum. To do so, TE1 modulates her proposal by inquiring about the length of the story (line 7) and encouraging the mother to tell it in Arabic if it is not too long (lines 8-9). This proposal, which as we have seen is not accepted by the mother (line 10), is received with surprise as shown by her raising intonation when pronouncing the word 'Arabic' (line 12), but welcomed by the other teacher (line 11) and the students (line 13).To persuade her to tell the story in Arabic, TE2 argues that there are a lot of children in the group who would understand the story in this language (lines 14-18) and children confirm so (line 15). Then TE2 proposes the solution of telling the story first in Arabic and later in Spanish (line 16-18). With his proposal TE2 is accommodating to the language the mother is using in this exchange.Yet,TE1 intervenes to point out that it should be retold in Catalan (not Spanish), asks the mother to confirm she has the text in this language (line 19) and reformulates the proposal of TE2 (lines 21, 29-31), who has already acknowledged his mistake (line 20). In this case, TE1 is affiliating to Catalan as the 'institutional language', as the mother had been doing. The affiliation of the two teachers to Catalan as the 'medium of interaction' when they are not interacting with the mother is also clear if we examine the embedded exchange in which they both address students who are being a bit noisy (lines 22-28) or the instances in which they address each other (line 20). Finally, the mother gives in, verbalises she accepts telling the story in Arabic (line 32, but makes a last attempt to negotiate the language in which she has to tell the story when she warns the teachers she will take long (line 33) in reference to the question TE1 had formulated in line 5 to suggest to her she could tell the story in Arabic and Catalan if it was not very long (lines 7-9). This 
move clearly illustrates she is not satisfied with the agreement and explains her discourse behaviour when the task starts (see excerpt 2).

This excerpt is interesting because it illustrates the 'practiced language policy' the adults are negotiating for this particular communicative event and the local meaning given to each of the instances of language alternation that emerge in the interaction. So, while the adults are negotiating the use of either Arabic or Catalan as the 'preferred' languages for the activity, the language choices and alternations all participants display are set on a broad array of norms. The mother affiliates to Spanish as her 'preferred' medium of interaction but understands Catalan (bilingual norm) and negotiates that Catalan is her 'preferred' language to tell the story. Students also affiliate to Spanish either to accommodate to the mother's preferred language or as their own language of preference. The two teachers affiliate to Catalan as the medium of communication between each other and with the children (ingroup norm) but enact less fixed (bilingual) norms when they address the mother. In the case of TE1, all her switches from Spanish to Catalan in this excerpt are contextualisation cues that signal a change in the activity and in the addressee: she corrects TE2 in Catalan (line 19) and formulates a confirmation check addressed to the mother in Spanish (line 19) or she ceases to negotiate language with the mother in Spanish (line 21) and starts to solve classroom management issues with the children in Catalan (line 22). Language choices and alternation in the case of TE2 are sustained on more unstable norms. At the beginning of the excerpt he also accommodates to the mother's language of preference, Spanish, but soon switches into Catalan in the same turn (lines 7-8). The same situation occurs a few minutes later (lines 16-17), which indexes he seems to struggle between aligning himself with his addressee's 'preferred' language or with the institutional 'preferred' medium of communication.

As we will see in excerpt 2, once the task starts, the situated meaning of code alternation and the norms of use deployed by participants are modified and reconfigured sequentially in talk-in-interaction.

Excerpt 2. Participants: The mother (MOT), two teachers (TE1 \& TE2) and some students, including Alex (ALE), Adib (ADI), student 1 (ST1), student 2 (ST2, students in choral voice (STS) and unidentified speakers (PPP)

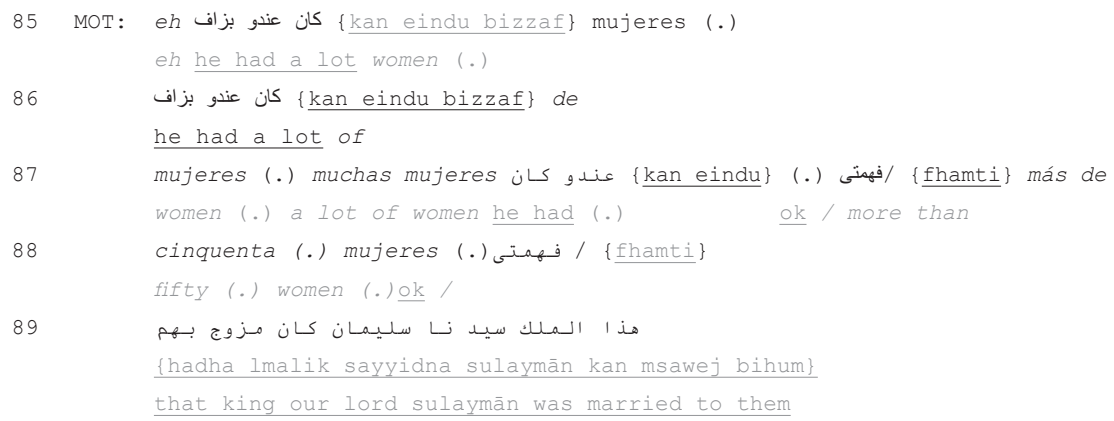


casado con eh quen con cincuenta mujeres/(.) sulaymān/(..) married to eh to to fifty women/(.) sulaymān/(..)

puedes explicar así/ mejor/ si/

can you tell it like this/ better/ yes/

TE2: [como XX]

$[a s \quad x x]$

TE1: [como tú lo hagas más cómoda]

[as you do it more comfortable]

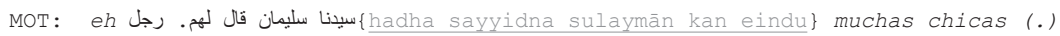
eh this our lord sulaymān had many girls (.)

hijas no tiene hijos (.) solo chicas (..) más de quinientos (.) daughters he didn't have sons (.) only girls (.) more than five hundred (.) muchos muchos muchos chicas (.)

many many many girls (.)

\{ Sayyidna sulaymān kalihum\} (. )

our lord sulaymān told them (.)

soy un hombre (.) uno رجل \{rajel\}

I am a man (.) one man

( (the mother makes a gesture indicating strength and children imitate her: see Figure 3.2))

hombre es رجل رجل رجل \{rajel\} en árabel\}

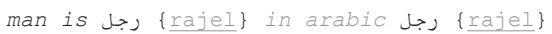

tengo que ten- que que (.) tengo que

(.) I have to I ha- to to (.) have to

tener un un niño y puedes que tengo un niño (2) el el demonios iج \{jinn\} have a a boy and you may that I have a boy (2) the the devils devil

((caughs and looks at a child while she pretends she is scaring demonds)) entiendes/ (.)

understand/ (.)
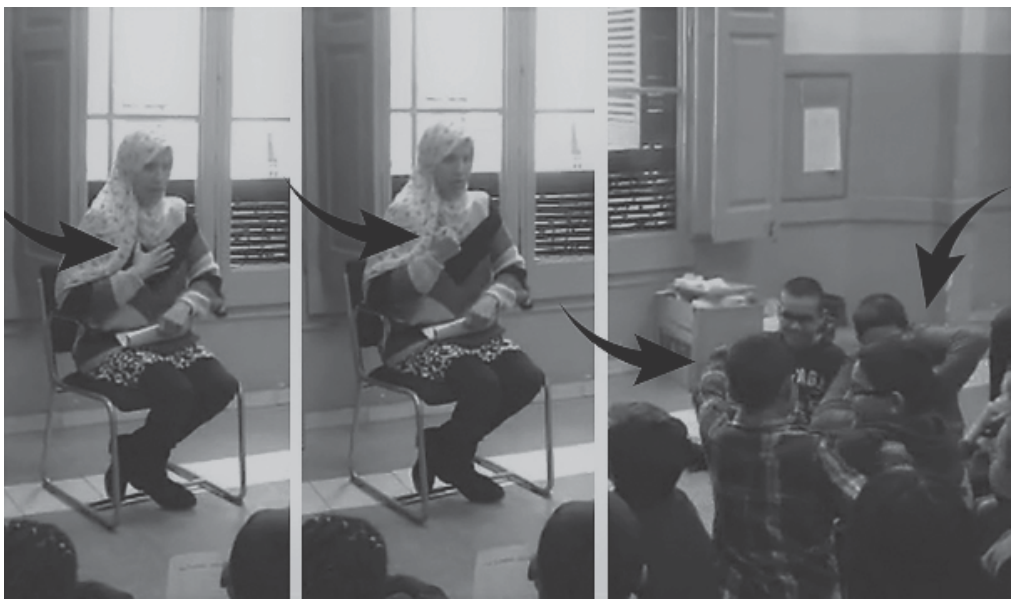

Figure 3.2 Students reproducing the gestures made by the mother 


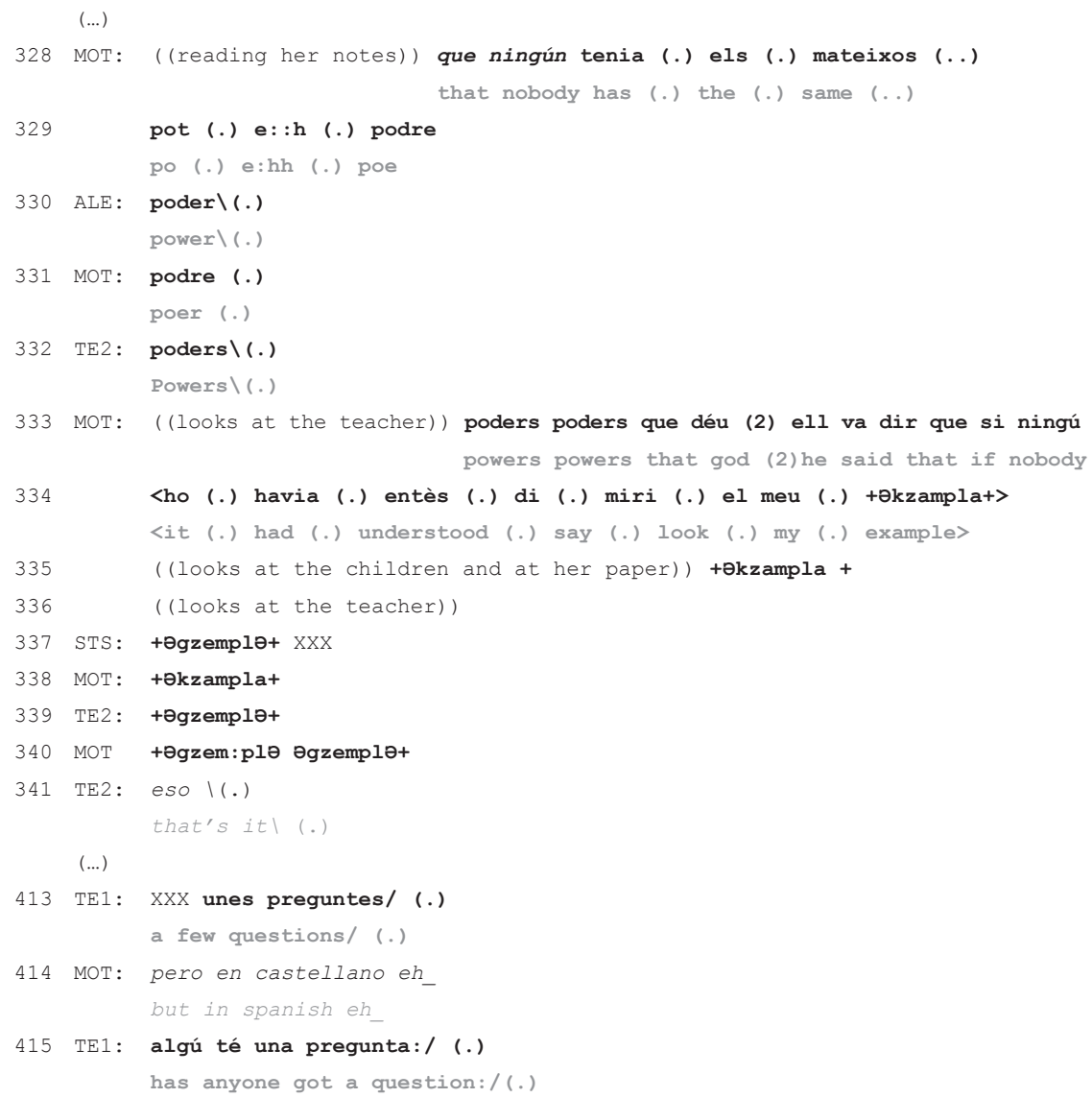

When the story starts, the medium used by the mother to tell the story is hybrid. Her use of Arabic discourse markers (فهنى \{fhamti\} / ok?, lines 87-88) indexes she is orienting to this language, as agreed. Yet, she also orients to her audience and thus resorts to body language (as in line 99) and Spanish to provide key words (as in lines 85-88; 94-98). Her discourse also unfolds through 'participant-oriented' language alternation moves to translate into Spanish what she has just said in Arabic (line 89-90) or to provide a clarification (lines 95-96). After this first attempt of employing plurilingual talk as a resource to tell the story in Arabic and make herself understood by an audience not necessarily familiar with this language, she explicitly addresses the teachers to confirm she can proceed in this hybrid medium (line 91). The teachers agree and she adopts this bilingual norm for about five minutes. Then she switches into Spanish, her 'preferred' medium of communication and tells the story in this language for about three and a half minutes (monolingual norm). At that point, she affiliates with Catalan as the institutional language and proposes to read the text she 
had prepared for such a purpose. On doing so, she very often hesitates when reading (e.g. she lengthens some of the sounds or repeats words, as in line 329) or requests for help with her gaze (line 335-336). These cues trigger hetero-repair moves initiated by the children (lines 330 and 337) and confirmed by TE2 (lines 332 and 339) to scaffold her discourse. The mother willingly accepts those lexical (lines 330 and 332) and phonetical (lines 337 and 339) repairs, as indicated by her repetition and incorporation of the repair items (lines 333 and 340).

When children become too noisy, she progressively stops reading and switches into Spanish to interact with the audience and complete the story. At the end, children give her a round of applause and TE1 invites students to ask questions (line 413). At this point, both adults align to their preferred medium of interaction: the mother to Spanish as the shared language she manages (line 414) and TE1 to Catalan (line 415) as displaying affiliation to the institution. Thus, 'practiced language policy' is again enacted through the norms of language choice and alternation described in excerpt 1

\section{Conclusions}

In this chapter we have examined a classroom task lead by a mother who has been invited to the class of her primary school child to tell an Arabic tale. Before and during the task participants engage in activities of language negotiation that reveal the complex norms of language use constructed in Catalan schools and society. Our data reveals that participants orient to different norms of 'practiced language policy' depending on whether they are conducting the activity or managing it. In this classroom event, in which the teachers want to create a plurilingual space open to the family language of some students in the group, both Arabic and Catalan are reconfigured as 'legitimate' languages to conduct the activity, but Spanish is not (excerpt 1, lines 16-20). When this norm becomes a 'practiced language policy', Spanish emerges because the mother, who is not proficient in Catalan, employs it as a scaffolding mechanism to ensure that the teachers and those students who do not speak Arabic can understand her.

The negotiation of the 'preferred' language to tell the story is not easy because the mother affiliates with her perceived language policy in the institution and insists on telling it in Catalan, which she pretends to do by reading it from a paper she brought with her (see excerpt 2, lines 328-340). As she does not master this language, Spanish is her 'preferred' language of interaction and uses it to negotiate with the teachers the language in which she will tell the story. The teachers following an accommodation norm quite widely spread in Catalan society when someone replies in Spanish, also address her in this language (excerpt 1, lines 2, 3, 5, 7, 11, 15, 21, 29-31; excerpt 2, lines 92-93 and 341); and students do that too (excerpt 1, line 15). Yet, TE2 affiliation to the accommodation norm is less stable and she occasionally switches into Catalan to address the mother (excerpt 1, lines 14,17,18), which shows affiliation to 
the institution. This ingroup norm (Catalan only) is strictly adopted by both teachers when they address each other (excerpt 1, line 20) or the children (excerpt 1, lines 22, 26 and 28; excerpt 2, lines 413 and 415). Our data, thus, reveal a tension between the speakers' 'declared language policy' (what they say/want to do) and the actual 'practiced language policy' (what they do as the interaction sequentially unfolds), explained by the affiliations to which interactants orient to (institutions or other participants) in talk-in-interaction.

\section{References}

Auer, P. (1984). Bilingual conversation. Amsterdam: Benjamins.

Auer, P. (1998). Bilingual conversation revisited. In P. Auer (Ed.), Code-switching in conversation. Language, interaction and identity (pp. 29-48). London/New York: Routledge.

Bonacina-Pugh, F. (2012). Researching 'practiced language policies': Insights from conversation analysis. Language Policy, 11, 213-234.

Candelier, M. (1998). L'éveil aux langues à l'école primaire, le programme européen EVLANG. In J. Billiez (Ed.) De la didactique des langues à la didactique du plurilinguisme, hommage à Louise Dabène. Grenoble: CDL-Lidilem. 299-308.

Candelier, M. (Ed.). (2003a). Evlang-l'éveil aux langues à l'école primaire-Bilan d'une innovation européenne. Brussels: De Boek-Duculot.

Candelier, M. (Ed.). (2003b), Janua linguarum - La porte des langues. L'introduction de l'éveil aux langues dans le curriculum. Strasboug: Conseil de l'Europe.

Castellotti, V., \& Moore, D. (2002), Représentations sociales des langues et enseignements Étude de référence, Strasbourg: Conseil d'Europe.

Committee for General and Technical Education (1973), The Connection between the Teaching and Learning of the Mother Tongue and the Teaching and Learning of other Modern Languages (Document Resume) Report of a symposium, Turku, Finland, December 11 through 16, 1972. Strasbourg: Council of Europe. Retrieved from https://eric. ed.gov/?id=ED086014.

Cots, J.M., \& Nussbaum, L. (2008) Communicative competence and institutional affiliation: interactional processes of identity construction by immigrant students in Catalonia. International Journal of Multilingualism, 5, 17-40.

Council of Europe (2001). Common European framework of reference for languages: Learning, teaching, assessment. Strasbourg: Council of Europe Publishing.

Council of Europe (2018). Common European framework of reference for languages: Learning, teaching, assessment - Companion volume. Strasbourg: Council of Europe Publishing.

de Goumoëns, C., Noguerol, A., Perregaux, Ch., \& Zurbriggen, É. (2003), Chapitre 2. La démarche et les supports didactiques. In M. Candelier (Ed.), L'éveil aux langues à l'école primaire. Evlang: bilan d'une innovation européenne (pp. 39-63). Brussels: De Boeck Supérieur.

Departament d'Ensenyament (2018). The language model of the Catalan education system: Language learning and use in a multilingual and multicultural educational environment. Barcelona: Generalitat de Catalunya / Ministry of Education. Retrieved from: http:// educacio.gencat.cat/web/.content/home/departament/publicacions/monografies/ model-linguistic/model-linguistic-Catalunya-ENG.pdf.

Gafaranga, J. (1999). Language choice as a significant aspect of talk organization: The orderliness of language alternation. Text, 19(2), 201-225. 
Galindo, M. (2008). Les llengües a l'hora del pati. Usos lingüístics en les converses dels infants de primària a Catalunya. Lleida: Pagès.

Gumperz, J. (1982). Discourse strategies. Cambridge: Cambridge University Press.

Hawkins, E. (1984), Awareness of language. An introduction, Cambridge: Cambridge University Press.

Masats, D. (2001). Language awareness: An international project. In D. Lasagabaster \& J. M. Sierra (Eds.), Language awareness in the foreign language classroom (pp. 79-97). Zarautz: Euskal Herriko Unibertsitatea.

Masats, D., Nussbaum, L., \& Unamuno, V. (2007). When the activity shapes the repertoire of second language learners. In L. Roberts, A. Gürel, S. Tatar, \& L. Marti (Eds.), EUROSLA Yearbook: Volume 7 (pp.121-147). Amsterdam: John Benjamins.

Musk, N., \& Cromdal, J. (2018). Analysing bilingual talk. In A. Filipi \& N. Markee (Eds.), Conversation analysis and language alternation: Capturing transitions in the classroom (pp. 15-34). Amsterdam: John Benjamins.

Noguerol, A. (2000) Aprendre llengua (i altres coses) des de la diversitat. Perspectiva $i$ Diversitat: Suplement de Perspectiva Escolar, 10, 3-6.

Nussbaum, L., \& Unamuno,V. (2006) (Eds.). Usos $i$ competències multilingües entre escolars d'origen immigrant. Bellaterra: Servei de publicacions de la Universitat Autònoma de Barcelona.

Perregaux, C. (1995). L'école, espace plurilingue. Lidil, 11, 125-139.

Spolsky, B. (2004). Language policy. Cambridge: Cambridge University Press.

Unamuno, V. (2015). Los hacedores de la EIB: un acercamiento a las políticas lingüísticoeducativas desde las aulas bilingües del Chaco. Archivos Analíticos de Políticas Educativas, 23(101), 1-31.

Vallejo, C., \& Noguerol, A. (2018). La multiculturalitat en els projectes de treball: Les catifes viatgeres. In S. Melo-Pfeifer \& C. Helmchen (Eds.), Plurilingual Literacy Practices. Oxford: Peter Lang.

Vila, I., \& Vial, S. (2000). Informe "escola $i$ ús". Les pràctiques lingüístiques de l'alumnat de $2 n$ nivell de cicle superior d'educació primària de Catalunya en situacions quasi-espontànies. Barcelona: Departament d'Ensenyament de la Generalitat de Catalunya.

Vilà, I., Siqués, C., \& Oller, J. (2009). Usos lingüístics de l'alumnat d'origen estranger a l'educació primària de Catalunya. Zeitschrift für Katalanistik, 22, 95-124.

Woolard. K. A. (1989). Double talk. Bilingualism and the politics of ethnicity in Catalonia. California: Stanford University Press.

Woolard, K. A. (2016). Singular and plural: Ideologies of linguistic authority in 21st century Catalonia. New York: Oxford University Press. 


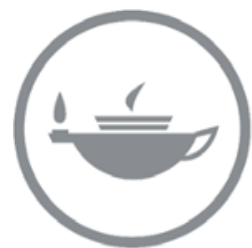

Taylor \& Francis Taylor \& Francis Group http://taylorandfrancis.com 
Part II

Students as plurilingual teachers 


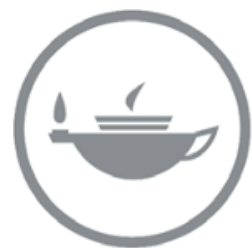

Taylor \& Francis Taylor \& Francis Group http://taylorandfrancis.com 


\section{Plurilingual practices and pluriliteracies in an after-school program}

\section{Encouraging children's use of their entire repertoire for meaning making}

\section{Claudia Vallejo}

\section{Introduction}

After-school activities are a regular feature in the agenda of many students. In Barcelona, where this research takes place, over 140 entities run afterschool support programs, mostly focused on languages and literacies (Síndic de Greuges, 2014). Local and international studies have shown the positive impact of after-school programs in students' academic and social trajectories, especially when they attend to children's diversity and promote flexible and collaborative dynamics (Crespo et al, 2014; González-Motos, 2016; Subero et al, 2017; among others). Research has also documented the potential of after-school programs to become spaces where children can display and develop their competence in areas that are not often acknowledged in formal school settings, including their everyday language and literacy practices and mediating skills (Hull and Schultz, 2001; Spielberger and Halpern, 2002; Gutiérrez, 2008; Creese and Blackledge, 2010; Li, 2011).

The interest in documenting and promoting educational dynamics that are more inclusive of students' plurilingual practices and pluriliteracies gains relevance in light of the new language model developed by authorities in Catalonia (Generalitat de Catalunya, 2018). The model advocates for an integrated linguistic approach as a means for equality, inclusiveness and social cohesion, and opens opportunities to incorporate children's home languages - when they are different from the curricular ones - and plurilingual repertoires and practices into the school curriculum. Among other measures, the model includes the possibility of offering immigrant background students' home languages in school hours as FL2 (a category reserved, up to now, to prestige European languages) and promotes schools' autonomy to design transversal, content and language integrated didactic approaches. This institutional bet for plurilingualism and linguistic diversity implies that documenting and understanding children's plurilingual and pluriliteracy practices, as displayed in other milieus, may 
contribute to promote more coordinated formal and non-formal educational praxis and to connect school learning to quotidian social life (Noguerol, 2008; Vallejo and Noguerol, 2018).

The data presented here was collected and analysed through ethnographic and socio-interactional methods (Mondada and Nussbaum, 2012; Gandulfo and Nussbaum, 2016; Moore and Dooly, 2017) in an after-school reading program for children considered 'at risk' of school failure. The data consist of two interactions in which a young girl displays her plurilingual repertoire and mediating skills for overcoming communicative obstacles and for meaning making while engaging in literacy-related activities with her reading mentor. The analysis aims at documenting the interactional practices that emerge in an after-school space, and particularly shedding light on the potential of promoting plurilingual literacy practices for encouraging children's use of their entire repertoire and mediating skills, and for re-distributing child-adult language expertise. It also aims at contributing to transform ingrained linguistic ideologies about the (lack of) competence of plurilingual speakers, and about the social and educational value of their repertoires and practices.

In the following sections we will present the theoretical framework that articulates the analysis, to then describe the main features of the after-school site where the data were collected. Next, we will introduce and analyse selected excerpts of child-volunteer interactions and, finally, we will discuss their implications in light of the described objectives.

\section{Theoretical framework: plurilingualism, pluriliteracies and language brokering}

Plurilingual approaches have been key in challenging long-standing assumptions that put monolingualism and language separation as the framework of reference to understand, implement and evaluate language use and language learning. A long tradition of interactional sociolinguists have documented empirical evidence that plurilingualism and plurilingual uses are not only the norm for most speakers and contexts, but also highly beneficial for meaning making, participation and learning (Nussbaum and Unamuno, 2006; Nussbaum, 2008; Lüdi and Py, 2009, among others), and a sign of the existence of a unique linguistic repertoire (Gumperz, 1964) and dynamic plurilingual competence (Coste, 2001). From this perspective, language learning is understood as a dynamic and collaborative process where pre-existent linguistic resources support the acquisition of new ones, where speakers' partial abilities in different languages are praised as learning and communicative resources, and where linguistic and non-linguistic modalities are intertwined (Goodwin, 2000) and strategically displayed according to the participants and situation.

Plurilingual approaches that emphasise the situated and dynamic nature of language use and language learning have also promoted an epistemological revision of what counts as valid knowledge, and recognition that language 
practices always take place in contexts of power - and resistance - that must be taken into account (Vallejo and Dooly, 2020). In this sense, the detailed analysis of plurilingual interactions can shed light on participants' sociolinguistic identities as they position themselves and others as experts or novices, validating - or not - diverse linguistic and literacy practices, and transpiring linguistic ideologies about what counts or not in educational contexts that often imprint adult-child interactions. Accounting for these phenomena, several authors have emphasised that social and educational understandings of language and literacy competence do not occur in isolation from other social parameters that operate with and beyond language and have an impact on academic achievement and social access (Codó and Patiño, 2014). Nussbaum and Unamuno (2006) also stress that social and educational evaluations and perceptions about plurilingualism are more related to social stereotypes and socioeconomic factors than to linguistic or pedagogical issues, resulting in the unequal appraisal of plurilingual uses that include prestige or less valued languages. This is especially relevant for minority language speakers; as Moore and Vallejo (2018: 25) point out:

A large body of research has demonstrated that the plurilingualisms and pluriliteracies that children and youth bring to classrooms are often not those required for school success. This is even more so for students from underprivileged backgrounds, a demographic where children and youth with family backgrounds of immigration are over-represented. [...] Thus, paradoxically, students who are 'pre-equipped' with diverse communicative repertoires that could be used to the benefit of their education, and of society, are often vulnerable to poor school results.

One particular - and often not-acknowledged - skill that many plurilingual children from migrant backgrounds are 'pre-equipped' with, is that of interpreting and translating oral interactions and written documents for their parents and other adults in various situations and settings. This particular form of intergenerational linguistic and cultural mediation is known as language brokering: "Language brokering refers to interpretation and translation between linguistically and culturally different parties. Unlike formal interpreters and translators, however, language brokers influence the messages they convey and may act as a decision maker for one or both parties" (Tse, 1995: 180). Tse, who coined the term 'language brokering' in reference to the task performed by children and youth - usually girls - for their immigrant parents, emphasises that language brokers "mediate, rather than merely transmit, information" according to the participants and situation, to facilitate adults' comprehension (Tse, 1996: 485). In their literature review on language brokering, Morales and Hanson (2005) indicate that existing research on the subject suggests that language brokers possess a highly developed plurilingual competence and literacy skills, and that their mediating task also involves emotional and family 
gains and challenges. Still, most authors agree that more research is needed to explore the influence of language brokering on children's language acquisition and development, academic performance, child-adult roles and interpersonal relationships.

Regarding language acquisition, Llompart's (2016) research builds on other studies from a conversation analysis perspective to explore the potential relationship between language brokering and inverse intergenerational linguistic transmission of the local language(s), usually from daughter to mother, but also to other adults (relatives, teachers, researchers), as well as between peers in school contexts. This and other studies show that, while language brokers engage in complex mediating tasks where they display sophisticated languaging and literacy skills usually above their grade level, and assume roles of expertise in regards to their parents in school and other social realms, these competences and efforts are not considered by educational institutions, where many of these children have a low academic achievement (McQuillan and Tse, 1995; Tse, 1995, 1996; Llompart, 2016; among others).

A similar claim can be done regarding the (lack of) educational inclusion and recognition of children's diverse literacy practices, extensively characterised by their plurilingual and multimodal nature. An extended corpus of literacy studies highlights the significant social transformations and complexity of current literacy practices due to human mobility and technological advances. In line with this, and building on ample previous research on (bi and multi) literacy studies and on the principles of plurilingualism, García, Bartlett, and Kleifgen (2007) proposed the term 'pluriliteracies' to refer to flexible, fluid and interrelated literacy practices around plurilingual, intercultural and multimodal texts, where the subjects' full repertoire is displayed. Pluriliteracies, then, expand understandings of literacy to acknowledge plurilingual and intercultural competences involved, as well as the multimodal complexity of current digital literacy practices and of child/youth culture. Such pluriliteracies are a significant component of the after-school program's ecology and of our data, as we will describe here.

\section{Context and participants}

The after-school reading program documented in this research, which is run by a non-profit Catalan organisation, takes place in a primary school in Barcelona located in the neighbourhood with the city's highest rate of immigrant population (Ajuntament de Barcelona, 2018). The demographics of the school and after-school program resemble those of the neighbourhood, with $90 \%$ of students either born abroad or in Catalonia to migrant parents. The program sessions run for an hour once a week and integrate two local coordinators, 24 - mostly local and female - volunteer mentors and 24 children of fourth and fifth grade of primary education, 22 with migrant backgrounds. The sessions are structured around reading and other literacy-related dynamics in pairs (child-mentor). The children have been allocated in the program by 
their school tutors based on considerations of not achieving the expected literacy levels in Catalan, Catalonia's own language and the vehicular language of the educational system and program. As a curiosity, the coordinators explained that, according to the external tests applied at the end of primary education, the school's results in English are significantly higher than in other curricular contents, which they relate to children's family repertoires or previous Englishmedium schooling. However, neither coordinators nor volunteers had much insight on the children's repertoires, and the reading material and activities provided by the program were only in Catalan.

The ethnographic research allowed us to identify child-mentor dynamics of alignment with this one-language-only institutional approach, as well as interactions where children displayed their entire repertoire and engaged in pluriliteracies. We will now present some of these moments from a specific reading pair (see Vallejo, 2020 for a complementary analysis of excerpt 1).

\section{Child-adult plurilingual and cultural brokering}

Hasu (pseudonym) is a ten-year-old girl born in Punjab, India, where she attended an English-medium school before migrating to Barcelona when she was eight years old. She reports she speaks Punjabi at home, Catalan, Spanish and English at school, and Hindi with a classmate from Pakistan. She recently learned to write and read in Punjabi at the local Sikh temple.

Her mentor in the after-school program is the researcher/author of this chapter, born in Chile and migrated to Barcelona 15 years earlier. Her L1 is Spanish and she learnt English at school and Catalan as an adult. She uses all three languages in her everyday life.

By Hasu's request, they have borrowed a book in Punjabi from the local library and agreed to read a few pages every session before moving to other readings in Catalan. In the following excerpt, Hasu explains to her mentor a page she has just read, which includes text in Punjabi and an illustration of a woman cooking and a bird eating some dough. The excerpt was registered in video by the mentor using her mobile phone.

Excerpt 1. 'Sparrow' Year 3 - session 6 (07.00-07.28). Participants: a student, Hasu (HAS), and her mentor (INV)

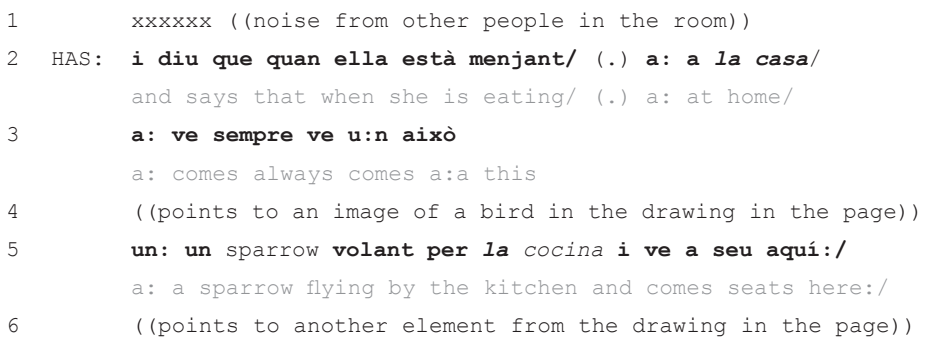


7

In this excerpt we see how Hasu uses her plurilingual competence to explain a text in Punjabi to her mentor. Hasu displays plurilingual and multimodal resources and strategies for overcoming communicative obstacles and for meaning making, while she orients to her perception of her mentor's linguistic and cultural experiences. In lines 5, 11 and 13, Hasu combines various linguistic codes (English, Spanish and Punjabi) along with Catalan. She also displays other semiotic resources, such as signalling at the book images (lines 4, 6, 8 and 10) and gesturing (lines 12) in conjunction with language. Her hybrid formulations might be participant-related (Auer 1984; Nussbaum, 2014) and emerge from her limited command of the vehicular language. As Masats, Nussbaum, and Unamuno (2007) note, initial language learners use resources from other languages they know to overcome communicative obstacles and participate in classroom activities. Both Hasu and her mentor seem to accept this code alternation as valid.

In lines 9 and 11, Hasu opens a side sequence to introduce some specific cultural information - about the making of Indian bread - that is not present in the text but necessary for the mentor to understand the story. This seems to indicate she possesses a sophisticated plurilingual and cultural brokering competence, as she is strategically selecting linguistic resources that she assumes are shared and therefore understandable and accepted, while providing extra cultural information when she judges it necessary to mediate between the text and her mentor. Even though the whole excerpt is basically made up of Hasu's explanation, its interactional nature and her orientation towards her interlocutor marks her selection and assemblage of plurilingual and multimodal resources. INV's final confirmation of understanding in line 14 successfully closes Hasu's strategic display of information.

All in all, the explanation and understanding of the book content is possible because of the existence of a plurilingual framework. Hasu and her mentor's alignment to this framework legitimate Hasu's free display of the different languages she knows within the program dynamics. This is especially so in the case of English, which she regularly introduces in their interactions. We will now present another example of this. 
Excerpt 2: 'Chili’Year 3 - session 8 (22.47 -23.26). Participants: a student, Hasu (HAS), and her mentor (INV)

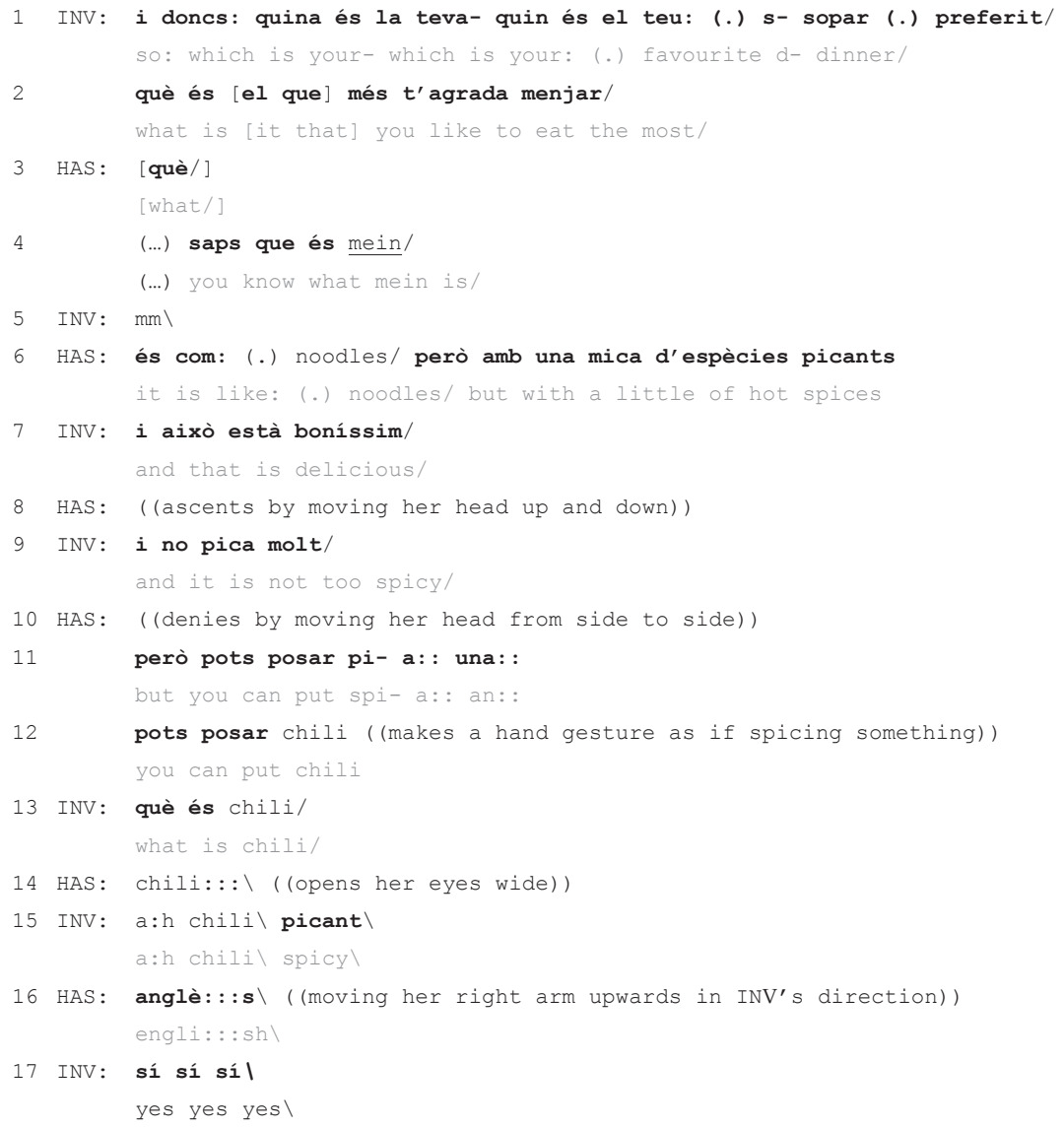

Similarly to excerpt 1 , both participants display diverse codes and strategies while orienting to their interlocutor, although a break in what had been built as a shared code emerges. The excerpt begins with INV asking Hasu about her favourite food in Catalan. In line 1, she hesitantly enunciates a question with pauses and interruptions, and immediately self-repairs by reformulating it in line 2, which overlaps with Hasu's request for clarification (line 3). Rather than just answering the question, Hasu checks her mentor's knowledge of the concept 'mein' (line 4). When INV denies, Hasu produces a plurilingual description including a word in English (noodles), but unlike in her previous turn, she does not check for her mentor's understanding of the concept. When in line 12 she introduces 'chili', her mentor's claim of not knowing its meaning is 
not followed by an explanation, but rather by a surprised reaction from Hasu, evidenced by her word lengthening, raising intonation and facial gestures (line 14). In line 15, INV manifests her understanding introducing a concept in Catalan (picant) that Hasu had previously discarded in preference of 'chili' (lines 11-12). Hasu then makes an explicit vindication of the use of English as a shared, self-explanatory resource (line 16). This also confirms her orientation to 'chili' as 'English'. Hasu's reaction and INV's subsequent alignment (line 17) manifest both a flexible distribution of language expertise and epistemic status, and a shared understanding of English as a legitimate feature in their plurilingual interactions that requires no checking or explanation, as opposed to other codes that can also emerge but imply clarification and checking for comprehension.

\section{Conclusions}

In this chapter we have documented a young girl's deployment of plurilingual and multimodal resources to read and convey meaning in interaction. We consider these actions as sign of a sophisticated plurilingual brokering competence whose display is allowed by the particular and flexible arrangements of the after-school context. The analysis also shows how the plurilingual child-mentor interactions follow some patterns of alignment with social appraisals of some (prestige) languages and plurilingual uses. Their alignment with the legitimacy of English is not surprising if we consider its social and curricular status, the school's good results in FL standard tests, and its role in Hasu's school trajectory in India. The academic legitimacy of English is also evidenced in the school's landscape, where Hasu's - and other students' - English literacy creations are regularly displayed in classroom walls; whereas no visual presence of students' heritage languages was found during our ethnographic work.

Meanwhile, other features presented in the data open spaces for 'hidden' abilities and languages to emerge. A clear example of this is the decision of this pair to include Hasu's home language into their reading dynamics, and their search for books in Punjabi beyond the program's monolingual offer - an unusual and significant fact. The access to literacy practices and materials that incorporate students' minority languages relates to issues of linguistic and social justice, as plurilingual speakers and their search for and consumption of literacy resources in the various languages they know can "both perpetuate and challenge language inequalities in their everyday lives" (Rivière, 2017: 348).

As the data show, this inclusion allowed the participants to engage in complex pluriliteracy practices across heritage and curricular languages, fostering collaboration and developing their plurilingual repertoire while displaying competent sociolinguistic identities and re-distributing child-adult language expertise (Llompart et al, 2020). This was possible due to Hasu's highly competent language and cultural brokering skills, as displayed in her mediation between the original text and her perception of her interlocutor's linguistic 
and cultural knowledge and background. Based on her situated understanding of the participants and situation, she recurred to those codes she presupposes are shared and legitimised by both participants, while actively selecting, adapting and expanding on the original content to facilitate her mentor's comprehension.

By documenting an example of a child's strategic display of her plurilingual repertoire and skilful language brokering for meaning making, we hope to put into value and contribute to a better understanding, in our educational institutions, of the sophisticated plurilingual competence and language and cultural mediating practices of children like Hasu. Finally, by describing the affordances of non-formal educational spaces in assembling a continuum of the diverse language and literacy practices that children usually engage in at different milieus, we hope to contribute to the endeavours expressed in the new Catalan educational model for promoting linguistically inclusive educational spaces, "overcoming the current situation where learning activities that take place in and out of school are often not mutually recognised" (Subero et al, 2017: 247), and eventually transforming prevailing ideologies about language separation and first and second-rate languages that still permeate educational practices.

\section{Acknowledgements}

This chapter has been written within the framework of the $\mathrm{PhD}$ in Education program at the Universitat Autònoma de Barcelona. The research described in this text could not have been possible without the after-school program adults and children - especially Hasu - and the invaluable support of my $\mathrm{PhD}$ supervisors.

\section{References}

Ajuntament de Barcelona (2018). Estadística $i$ difusió de dades: dades per barris. Barcelona: Departament d'Estadística i Difusió de Dades. Retrieved from: www.bcn. cat/estadistica/castella/dades/barris/tdemo/imi/nacn2018.htm.

Auer, P. (1984). Bilingual conversation. Amsterdam: John Benjamins.

Codó, E., \& Patino, A. (2014). Beyond language: Class, social categorisation and academic achievement in a Catalan high school. Linguistics and Education, 25, 51-63.

Coste, D. (2001). La notion de compétence plurilingue. Actes du séminaire: L'enseignement des langues vivantes, perspectives. Paris: Ministère de la Jeunesse de l'Education et de la Recherche.

Creese, A., \& Blackledge, A. (2010). Translanguaging in the bilingual classroom: A pedagogy for learning and teaching? Modern Language Journal, 94 (1), 103-115.

Crespo, I., Lalueza J. L., Lamas, M., Padrós, M., \& Sanchez Busqués, S. (2014). El proyecto Shere Rom. Fundamentos de una comunidad de prácticas para la inclusión educativa de grupos culturales minoritarios y en riesgo de exclusión social. Psicología, Conocimiento y Sociedad, 4 (2), 138-162. 
Gandulfo, C., \& Nussbaum, L. (2016). Hablantes bi/plurilingües y prácticas educativas: Perspectivas etnográficas e interaccionistas. Signo y Seña, 29, 5-10.

García, O., Bartlett, L., \& Kleifgen, J. (2007). From bilingualism to plurilingualism. In P. Auer \& Li Wei (Eds.), Handbook of multilingualism and multilingual communication. Volume 5: Multilingualism (pp. 207-228). The Hague: Mouton de Gruyter.

Generalitat de Catalunya (2018). Language model of the Catalan education system: Language learning and use in a multilingual and multicultural educational environment. Retrieved from:http://ensenyament.gencat.cat/web/.content/home/departament/publicacions/ monografies/model-linguistic/model-linguistic-Catalunya-ENG.pdf.

González-Motos, S. (2016). Quin impacte tenen les activitats extraescolars sobre els aprenentatges dels infants i joves? Barcelona: Fundació Jaume Bofill-Ivàlua.

Goodwin, C. (2000). Action and embodiment within situated human interaction. Journal of Pragmatics, 32, 1489-1522.

Gumperz, J. (1964). Linguistic and social interaction in two communities. American Anthropologist, 66(6), 137-153.

Gutiérrez, K. (2008). Developing a sociocritical literacy in the Third Space. Reading Research Quarterly, 43(2), 148-164.

Hull, G., \& Schultz, K. (2001). Literacy and learning out of school: A review of theory and practice. Review of Educational Research, 71(4), 575-611.

Li, W. (2011). Moment analysis and translanguaging space: Discursive construction of identities by multilingual Chinese youth in Britain. Journal of Pragmatics, 43, 1222-1235.

Llompart, J. (2016). Pràctiques plurilingües d'escolars d'un institut superdivers: De la recerca a l'acció educativa. (Unpublished $\mathrm{PhD}$ thesis). Universitat Autònoma de Barcelona, Bellaterra.

Llompart, J., Masats, D., Moore, E. \& Nussbaum, L. (2020). 'Mézclalo un poquito': Plurilingual practices in multilingual educational milieus. Special Issue: International Journal of Bilingual Education and Bilingualism, 23(1), 98-112.

Lüdi, G., \& Py, B. (2009). To be or not to be... a plurilingual speaker. International Journal of Multilingualism, 6(2), 154-167.

Masats, D., Nussbaum, L., \& Unamuno, V. (2007). When activity shapes the repertoire of second language learners. In L. Roberts, A. Gürel, S. Tatar \& L. Marti (Eds.), EUROSLA Yearbook: Volume 7 (pp.121-147). Amsterdam: John Benjamins.

McQuillan, J., \& Tse, L. (1995). Child language brokering in linguistic minority communities: Effects on cultural interaction, cognition, and literacy. Journal of Language and Education, 9(3), 195-215.

Mondada, L., \& Nussbaum, L. (Eds.) (2012). Interactions cosmopolites: L'organisation de la participation plurilingue. Limoges: Editions Lambert Lucas.

Moore, E., \& Dooly, M. (Eds.) (2017). Qualitative approaches to research on plurilingual education / Enfocaments qualitatius per a la recerca en educació plurilingüe / Enfoques cualitativos para la investigación en educación plurilingüe. Dublín/Voillans: Research-publishing.net.

Moore, E., \& Vallejo, C. (2018). Practices of conformity and transgression in an out-ofschool reading programme for 'at risk' children. Linguistics and Education, 43, 25-38.

Morales, A., \& Hanson, W. (2005). Language brokering: An integrative review of the literature. Hispanic Journal of Behavioral Sciences, 27(4), 471-503.

Noguerol, A. (2008). El tratamiento integrado de lenguas en el marco europeo. Textos de didáctica de la lengua y la literatura, 47, 10-19. 
Nussbaum, L. (2008) Construire le plurilinguisme à l'école: De la recherche a l'intervention et de l'intervention à la recherche. In M. Candelier, G. Ioannitou, D. Omer, \& M. T. Vasseur (Eds.), Conscience du plurilinguisme. Pratiques, représentations et interventionsn (pp. 125-144). Rennes: Presses Universitaires de Rennes.

Nussbaum, L. (2014). Una didàctica del plurilingüisme. Bellaterra Journal of Teaching \& Learning Language \& Literature, 7(3), 1-13.

Nussbaum, L., \& Unamuno,V. (2006). Usos i competències multilingües entre escolars d'origen immigrant. Bellaterra: Serveis de Publicacions de la UAB.

Rivière, M. (2017). Plurilingual reading practices in a global context: Circulation of books and linguistic inequalities. Studies in Second Language Learning and Teaching, $7(32), 335-354$.

Síndic de Greuges de Catalunya (2014). Informe sobre el dret al lleure educatiu i a les sortides i colònies escolars. Barcelona: Síndic de Greuges de Catalunya.

Spielberger, J., \& Halpern, R. (2002). The role of after-school programs in children's literacy development. Chicago, IL: Chaplin Hall Centre.

Subero, D., Vujasinovic, E., \& Esteban-Guitart, M. (2017). Mobilising funds of identity in and out of school. Cambridge Journal of Education, 2, 247-263.

Tse, L. (1995). Language brokering among Latino adolescents: Prevalence, attitudes, and school performance. Hispanic Journal of Behavioral Sciences, 17(2),180-193.

Tse, L. (1996). Language brokering in linguistic minority communities: The case of Chinese- and Vietnamese-American students. Bilingual Research Journal, 20 (3), 485-498.

Vallejo, C. (2020). Translanguaging as practice and as outcome: Bridging across educational milieus through a collaborative service-learning project. In E. Moore, J. Bradley, \& J. Simpson (Eds.), Translanguaging as transformation: The collaborative construction of new linguistic realities (pp. 234-250). London: Multilingual Matters.

Vallejo, C., \& Dooly, M. (2020). Plurilingualism and translanguaging: Emergent approaches and shared concerns. Introduction to the special issue. International Journal of Bilingual Education and Bilingualism, 23(1), 1-16.

Vallejo, C., \& Noguerol, A. (2018). La multiculturalitat en els projectes de treball: Les catifes viatgeres. In S. Melo-Pfeifer \& C. Helmchen (Eds.), Plurilingual Literacy Practices (pp. 103-118). Berlin, Peter Lang. 


\section{Students as teachers, teacher as learner \\ Collaborative plurilingual teaching and learning in interaction}

\section{Júlia Llompart}

\section{Introduction}

Schools, especially in urban centres, have received a large population of students of migrant origins in recent decades, transforming them into multicultural and multilingual spaces. In response, since the beginning of this century, the tendency has been to promote a 'multilingual turn' (Conteh and Meier (2014) in language education and to push for plurilingual approaches, such as 'pluralistic approaches to languages and cultures' (Candelier, 2008) and 'language awareness' (Cots and Nussbaum, 2002; Cenoz, Gorter, and May, 2017). However, implementing plurilingual policies and teaching practices is still a pending challenge. In fact, some monolingually-oriented ideas persist - such as the one language only perspective in classrooms - and plurilingual students are positioned as non-expert language learners, thus resulting in unidirectional language transmission. However, in past decades, methodologies have emerged focusing on allowing children and youth to become active agents in the process of teaching and learning - such as Rodriguez and Brown's (2009) participatory action-research; Kellett's (2005) and Thomson and Gunter's (2007) approach to students as researchers; or Stetsenko's (2014) transformative activist research. These proposals aim to value and incorporate students' knowledge and competencies and to re-shape the traditional classroom hierarchies and ways of participating. By allowing students to be active participants and by valuing their linguistic repertoires (the focus of this chapter), expert and non-expert identities may be negotiated and collaboratively constructed, in order to shape the process of teaching and learning (Hall and Walsh, 2002), and the traditional structure of classroom lessons and interactions is modified.

This chapter builds from the active and transformative methodology of positioning students as language researchers and teachers, and thus experts in a multilingual context. The objective is to describe the emergence and interactional construction of teacher and learner categories during an activity in which students in a high school teach Urdu to their Spanish teacher. Firstly, some theoretical considerations that will guide the analysis will be briefly introduced; then the data and the focus of the analysis will be presented; after 
that the data will be analysed and discussed; finally, some concluding remarks will be offered.

\section{Theoretical framework}

Classroom interaction and social activities have been researched from different perspectives (Moore and Nussbaum, 2013). Since the late 1970s, several researchers have taken up interactional approaches in order to understand and describe the structure of classroom lessons and teacher-student interactions. More specifically, the pioneering studies of McHoul (1978) and Mehan (1979) followed ethnomethological and Conversation Analysis (CA) orientations. Departing from CA's general rules of talk - regarding the management of turns - McHoul (1978) accounted for the organisation of classroom talk and described certain rules and rights of participants ('student'/'teacher', the latter being the 'director', managing speakership and timing), as well as how repair is dealt with in classroom interaction. Taking an ethnomethodological approach, Mehan (1979) described several classroom instances such as lessons and identified the well-known IRF interactional activity sequence (Initiation, Response, Feedback, Sinclair and Coulthard (1975), reformulated as Initiation, Response, Evaluation or IRE in Mehan (1979)). In this sequence the Initiation and the Feedback/Evaluation is done by the teacher - a role traditionally assigned to the adult in charge of the class - and the Response by the student - assigned to children and youth, thus representing a teacher-centred structure. Following the CA perspective, in more recent years, researchers such as Markee (2000), Seedhouse (2004) or Mori and Zuengler (2008) have advanced in the understanding of the processes of language learning and teaching in classrooms by introducing, for instance, detailed transcriptions and video-recordings, which allow a more precise understanding of talk-in-interaction. The focus on turn-taking and repair in classroom interaction analysis has been very fruitful for understanding the talk structure in this particular context, by identifying, for example, the turntaking structure - specially in IRF sequences - and students' agency and possibility of participating and learning. Although traditionally the roles of the agents in the IRF sequence have been pre-assigned and static, the detailed study of talk-in-interaction has shown that these sequences can be shifted by student participation (Waring, 2009) and children and youth might take on the role of teachers (Llompart, 2016; see also Nussbaum in this volume).

The empirical power of CA has allowed for the analysis, turn by turn, of the sequential development of interactive talk in order to discover the sequential organisation of actions as well as the maintenance of intersubjectivity (Sacks, Schegloff, and Jefferson, 1974). Sequentiality is, then, a key notion to analyse classroom interaction and to observe what the practical actions taken up by the speakers are and how identities are constructed in talk-ininteraction. Several researchers (Antaki and Widdicombe, 1998; Goodwin and Kyratzis, 2011, for instance) describe identity as a negotiable, flexible 
and variable social construction, which can be observed in the categorisation processes that unfold in interaction between people. Sacks (1992) defined social categorisations as devices that carry implicit knowledge of society and culture and that are organised in 'standardised relational pairs' (Stokoe, 2012) -for example, 'teacher'-'pupil' or 'parent'-'child'- and which entail certain rights and obligations. Moreover, there are certain activities, called 'category-bound activities', that are connected to the categorisations and that implicitly show participants' orientations in constructing intersubjectivity in interaction. For instance, in the predicate 'students need to listen to the teacher', 'students' and 'teacher' are categories, which are related pairs, and 'need to listen to the teacher' is a category bound activity related to the category 'student'. According to Richards (2006: 16), referring to 'teacher'-'learner' categorisations, “previous discourse-based research in this setting has worked entirely from the default position, taking these situated identities as given and exploring how discursive identities can be manipulated to pedagogic advantage" and also based on an asymmetry of knowledge (Drew, 1991) - being the teacher the party with absolute or highest knowledge. In his study Richards (2006) showed how the 'teacher'-'student' identity construction was related to the development of talk-in-interaction instead of being pre-assigned and static. This goes in line with Heritage's (2012) conception of epistemic access to knowledge as being "stratified between interlocutors such as they occupy different positions on an epistemic gradient (more knowledgeable $[\mathrm{K}+]$ or less knowledgeable [K-]" (p. 4). The epistemic status of individuals is relative to others and is dependent on domain and can change moment to moment in the interaction (Heritage, 2012); this knowledge relationship between participants is expressed, turn by turn, by epistemic stances, through the format of actions or turn design, and thus participants can negotiate and transform epistemic status (Mondada, 2013). Focusing on classroom interaction, Kasper (2009) pointed out that, whether from a $\mathrm{K}+$ or a $\mathrm{K}$ - position, participants in an interaction engage in common socially shared interactional competences for language learning and teaching, such as repair sequences.

In this chapter, CA research and ethnomethodological orientations will be followed; especially paying attention to previously introduced key notions, such as sequentiality, identity construction, category emergence in interaction and epistemic position. The interaction between an adult in charge of a class and a group of multilingual youth will be analysed, turn by turn, in order to describe a collaborative process of teaching and learning plurilingually.

\section{Methodology}

The data that we analyse in this chapter were collected in a high school with more than $90 \%$ of students from immigrant origin (mainly from Pakistan, India, Morocco, Bangladesh); some had recently arrived in Catalonia and others were either born there or had been living there for some years. They were specifically 
obtained in a classroom with around 15 students from different origins who had been in Catalonia for one or two years. The Spanish class teacher of this group was an experienced professional who had worked as a high school educator for more than 20 years, but who had been assigned a multilingual and multicultural group of students for the first time in her career. After detecting that the same traditional methods she had used for years did not work for these plurilingual students, she decided to take on a collaborative project between a researcher, the students and herself. In the project, called Pluripedia, students became researchers and had to create a multilingual visual encyclopaedia, which included vocabulary and sentences in all the students' languages. The Pluripedia was meant to help the more newly arrived students to communicate during the first stages of their stay. The group of students participating in the project decided which languages and what vocabulary and sentences to include (in Spanish and Catalan), took the necessary pictures or looked for them on the Internet, participated in scientific sessions to discuss the contents and some linguistic aspects and created the final version of the Pluripedia.

In the next section, following CA perspectives, how teacher and student categories and identities emerge and are negotiated in interaction will be analysed, as well as how knowledge and epistemic status are distributed in a plurilingual classroom.

\section{Analysis and discussion}

During one of the scientific sessions, the students who spoke Urdu worked in group in order to prepare some questions regarding information for registering newly arrived students. Figure 5.1 includes the result of this work - the part written in dark - and the teacher's translations and notes into Spanish - the part written in pencil.

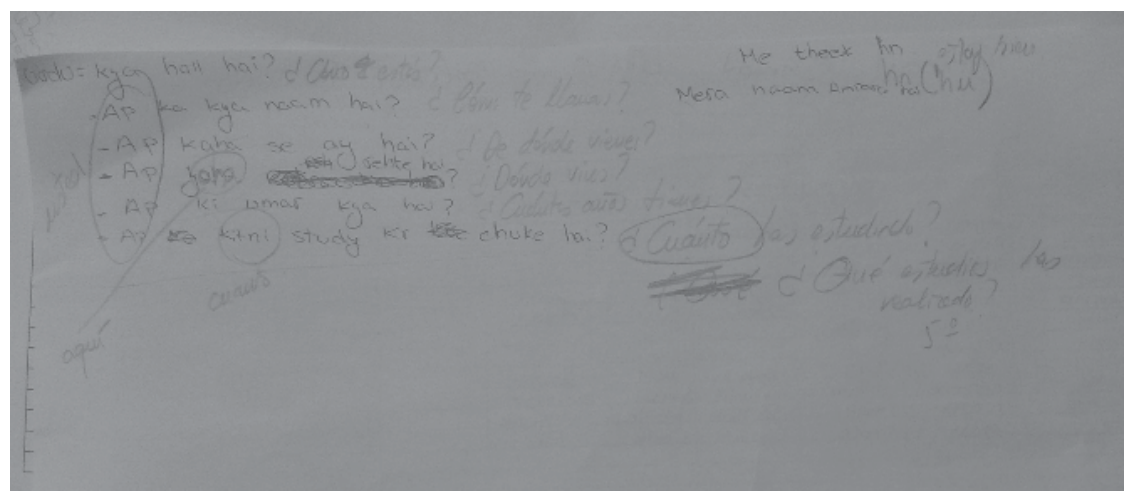

Figure 5.I Result of the activity 
Once the students had finished, the teacher sat down with two of them from Pakistan, Nora (NOR) and Deena (DEE), with Nora sitting on the classroom floor and thus in a lower position, and started to scrutinise the document and to ask about the meaning of the sentences, in order to ensure correctness of the task done by the youth. In the middle of the activity, a student from Morocco, Mouna (MOU), also joins the group and, later on, so does another student from Pakistan, Madeeha (MAD). Excerpt 1 begins with the explanation of the sixth and last sentence in the document ("Ap kitni study kr chuke hai?").

Excerpt 1. Participants: Dolores (DOL, teacher), Nora (NOR), Deena (DEE), Mouna (MOU)

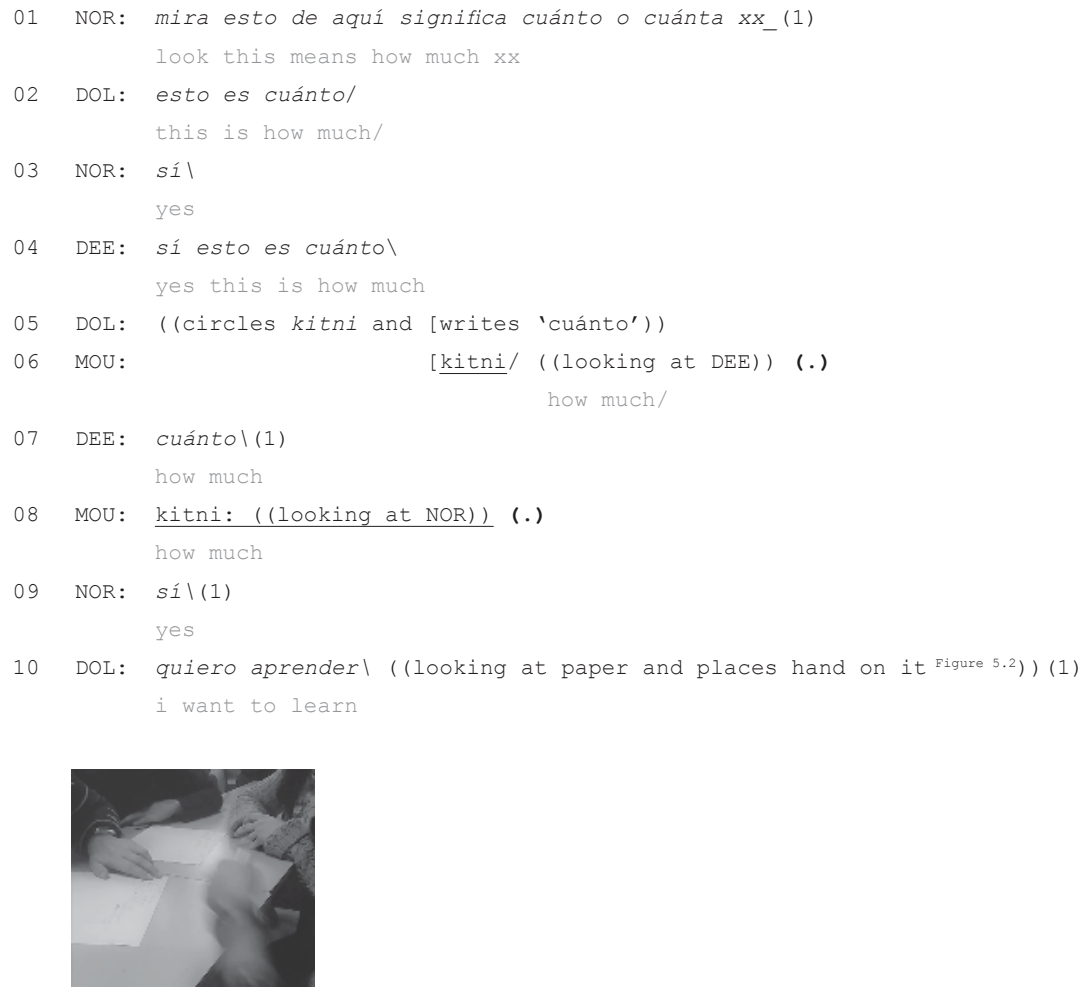

Figure 5.2

11 DEE: [si sabes anglès profe:

if you know english teacher

12 NOR: [( (puts hand also on paper Figure 5.3)) 


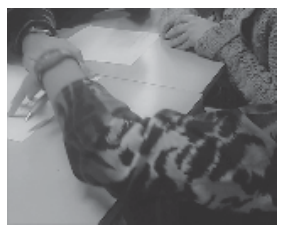

Figure 5.3

13 NOR: ((stands up from floor, sits on chair, faces DOL and points at sentence DOL is pointing at Figure 5.4 ))

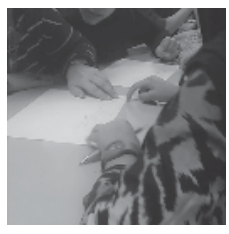

Figure 5.4

As may be observed in this excerpt, DOL tries to translate the sentences written in Urdu with the help of the students in order to ensure that the work they have done is correct. After NOR has pointed out the meaning of the word 'kitni' (in line 1), DOL looks for confirmation of the word NOR is referring to, in line 2. Both NOR and DEE confirm it and DOL proceeds to note this connection on the paper by circling both words (line 5; see Figure 5.1). While DOL is doing that, MOU, the student of Moroccan origin who does not speak Urdu, also asks for confirmation -first, by looking at DEE (line 6), who confirms by giving her the translation of the word, and then by looking at NOR (line 8), thus categorizing both of them as Urdu experts. After these requests for confirmation, in line 10, DOL, who has previously taken on the role of reviewer and translator, and thus mediator between what the students had prepared and her understanding, demands a change in her role as participant in the interaction, as well as in her role as student, through the predicate "quiero aprender" ("I want to learn") but also through a category bound activity related to the category 'student': positioning her finger on the first sentence in the paper (Figure 5.2). Both DEE and NOR respond to DOL's claim in overlap - DEE, in line 11, offers her a hint to understand or learn Urdu, since the variety of it they use includes many words in English, while NOR, in line 12, also moves her hand on the paper (Figure 5.3). As soon as she realises she is not in an ideal body position to carry out the teaching activity, she stands up from the floor and sits on a chair to be able to face DOL and point at the first sentence of the paper with her finger (Figure 5.4). Both students 
have self-categorised as experts in Urdu language: DEE by providing a metalinguistic reflection and NOR by multimodally responding to DOL's request to be taught. A turning point in the interaction is cued.

Although in excerpt 1 DOL is already trying to understand Urdu, she is managing the activity and acting as a reviewer. Nevertheless, despite DOL is the one who corrects the activity, the epistemic status of the teacher is not static since the students' knowledge is clearly needed to proceed with the activity. This is even clearer in excerpt 2.

Excerpt 2. Participants: Dolores (DOL, teacher), Nora (NOR), Deena (DEE), Madeeha (MAD)
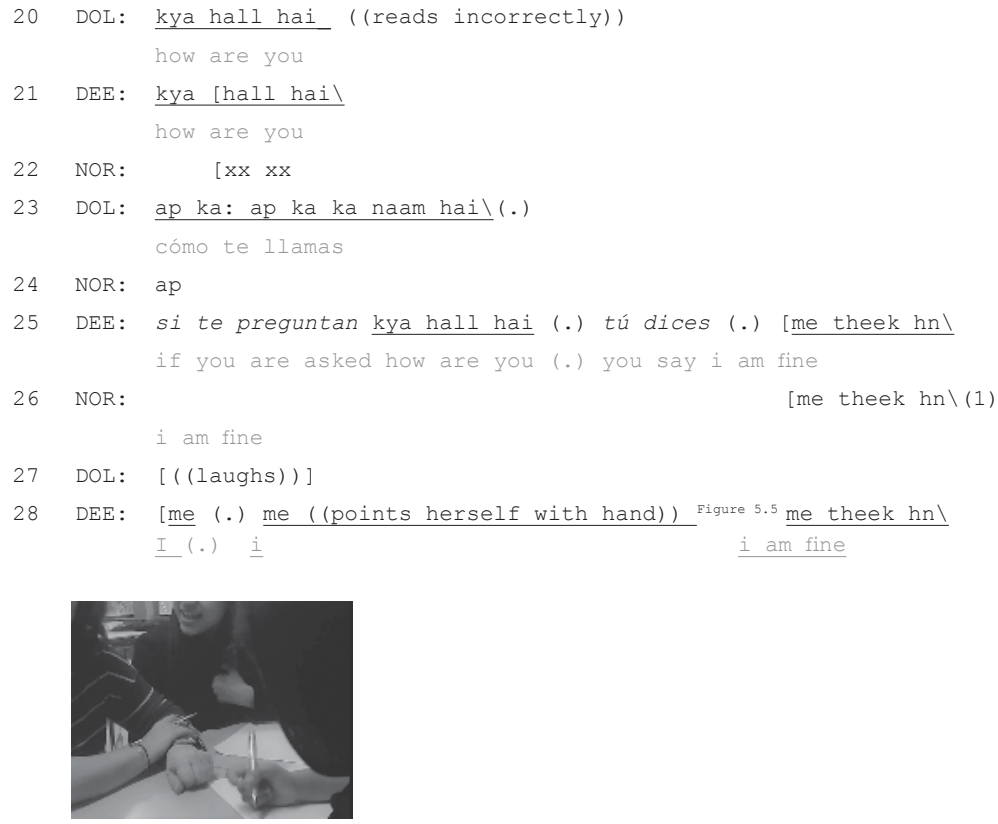

Figure 5.5

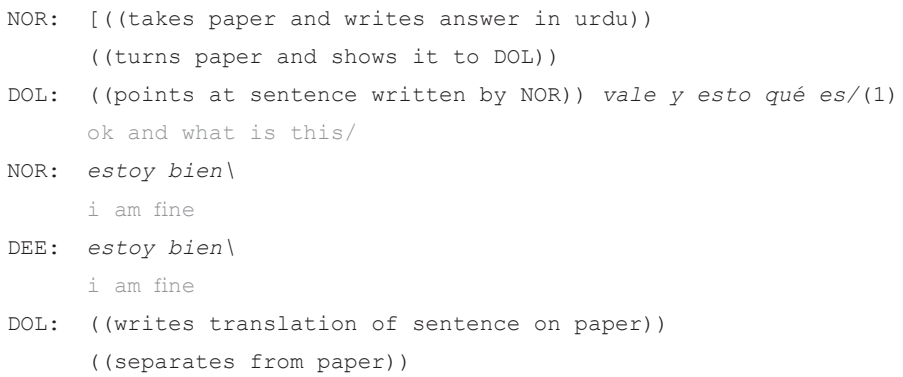


$$
37
$$$$
38
$$
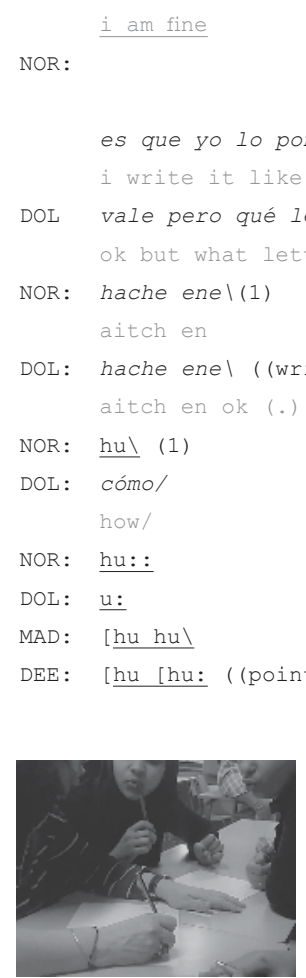

NOR:

NOR: hache enel(1)

aitch en

DOL: cómo/

how/

NOR: hu: :

DOL: $\underline{\mathrm{u}}:$

MAD: [hu hu\}

DOL: me theek ((leans to write on the paper)) hu pero [esto esto es una ene/

es que yo lo pongo así_

i write it like this

DOL vale pero qué letra es/(pointing at the paper with the pencil)) (.) ok but what letter is this/

DOL: hache enel ((writes on paper)) hache y ene y la pronuncia es u $\backslash$ (.)

aitch en ok (.) aitch and en and pronunciation is u

NOR: $\underline{\mathrm{hu} \backslash}(1)$

DEE: [hu [hu: ( (pointing at her lips Eigure 5.6))

Figure 5.6

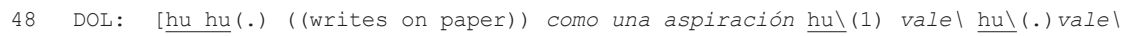
hu hu (.) like an aspiration hu (1) ok \hu (.) okey

DOL initiates a new sequence in line 20 where she self-categorises as learner, which she has previously declared, and tries to pronounce the first of the sentences in Urdu. This implies the hetero-categorisation of the girls as Urdu experts, and thus a change in epistemic status, which is accepted by DEE, who also offers DOL the correct pronunciation of the sentence and by NOR who also responds. In line $23, \mathrm{DOL}$ repeats the same action by reading another sentence to which NOR orients by starting to offer DOL the correct pronunciation of it. On the other hand, DEE, in line 25, expands her role as expert by providing not only the pronunciation of the previous sentence in Urdu but also a correct answer to it, that is collaboratively provided in overlap with NOR. The pause in line 26 and DOL's laughter in line 27 are interpreted by DEE and NOR as DOL not having understood the answer in Urdu and both students initiate a repair: in line 28 , DEE provides a divided version of 
the sentence by, first, multimodally, pointing at herself (Figure 5.5) - indicating what "me" means and, then, repeating the whole sentence. NOR, at the same time, takes the paper and orients it towards her in order to write the sentence for DOL (see Figure 5.1, top right). Both activities - multimodally indicating the meaning and writing the sentence - could be considered category-bound activities, related to the category 'teacher', through which DEE and NOR are 'doing being a teacher'. In line 30, NOR turns the paper towards DOL who points at the sentence (line 31) and asks about its meaning.

After a pause, in line 32, NOR - and, right after her, DEE - offers DOL the translation of the sentence into Spanish. DOL proceeds to write the translation of the sentence on the paper and thus continues orienting towards the teaching-learning activity. In line 36, DOL, following what NOR has written, starts to pronounce the sentence in Urdu again but, in the last part, she finds trouble ("hn") because she had previously understood "hu". Her focus is on the correction of the spelling and thus she again adopts the role of teacher/reviewer (line 36, "esto es una ene"). In line 37, NOR orients, first, towards the continuation of her teaching activity by offering the correct pronunciation of 'hn' and, then, in line 38, she aligns with the correction activity initiated by DOL and justifies the way she transliterates it into the Latin alphabet. In the following line, DOL directly requests which letters are written in that specific word (line 39), by pointing to the word 'hn' with the pencil. NOR, in line 40, responds by giving the letters and, in line 41 , DOL repeats and writes them on the paper (see Figure 5.1, right top, in pencil). After that, she re-orients towards the learning and teaching activity by looking at NOR and asking if the pronunciation is correct. In line 42, NOR initiates a repair by offering DOL the correct pronunciation. After a pause, DOL asks NOR for a repetition of the pronunciation of the word 'hn', which is answered offering a louder version with more emphasis on the aspiration, in line 44. Following NOR's model, in line 45, DOL tries to pronounce the word again but it is not accepted by MAD - a student from Pakistan who has joined the group - nor by DEE who, in line 47, does not only offer the correct model to DOL again but who also shows her, by using multimodal resources (see Figure 5.6), what is the key to its correct pronunciation. In doing so, DEE is clearly 'doing being a teacher'. In the next line, DOL orients towards DEE's multimodal resources and pronounces the word by imitating DEE's position of the mouth, first, and then expands this orientation by offering a metalinguistic explanation for the pronunciation ("like an aspiration"). So, in excerpt 2, we can clearly observe how the teacher and student categorisations are constructed in the interaction, related to the epistemic position of each participant. The continuation of the teaching and learning of Urdu enterprise can be observed in the data collected.

The interactional analysis of these two sequential excerpts has helped describe the collaborative deployment of a correction activity and of a plurilingual teaching and learning activity between an adult and a group of teenagers. In excerpt 1 , the main activity being carried out was the correction 
of the sentences prepared by the students for the project, which consists of Dolores asking for the translation of the Urdu sentences into Spanish, from which she accepts or demands some change. Although the knowledge of the teenagers is clearly taken into account and useful for the progression of the activity, Dolores' role is that of a teacher, which is constructed through several category-bound activities, such as management of the activity or initiation of IRF sequences (although not traditional ones since she does not know the answers). Nevertheless, Dolores, by situating Urdu language as knowledge needed for the activity, hetero-categorises the teenagers as experts. The end of the first part of the excerpt opens the door to the teaching and learning activity in the following section. In excerpt 2, the change in the traditional roles of teacher and students is clear; when the activity orients towards the correction for the project, Dolores is categorised as the teacher. But, when she situates herself as a student of the Urdu language, the teenagers are categorised as teachers who collaboratively deploy several pedagogical procedures related to doing being a teacher - category-bound activities such as pointing at the sentences that need to be read, offering the correct model, multimodally indicating the meaning of a word or re-positioning the body. All in all, the analysis of these data have shown how by positioning students as participants and as experts in their languages, Urdu, in this case, the traditional knowledge asymmetry associated with classroom talk is changed and the youth can take up roles as experts and thus direct the teaching activity and introduce metalinguistic reflections. Actually, the adult's admission of her lack of competence in Urdu language (thus her $\mathrm{K}$ - status regarding this) accounts for the youth's participation and transformation into teachers and experts.

\section{Conclusions}

One of the main objectives of the Pluripedia project was to subvert the traditional class dynamic - which was not working - by giving value to the students' plurilingual repertoire and by situating them as full participants and agents in their process of learning. Moreover, the design of the different activities and the scientific sessions set out from the crucial idea of understanding that the students are experts in their respective languages and that their knowledge is valid for academic work. Space and voice were given to them to prepare each of the activities and to discuss linguistic issues.

Following this logic, both the adult and the teenagers had an active role, as our data have shown. The class teacher was in charge of the correctness of the sentences prepared for the Pluripedia, self-categorising as reviewer and mainly as teacher, but she also takes up another - both identitary and epistemic - position when she categorises as a student and learner of Urdu. By doing so, she also hetero-categorises the youth as teachers and as experts. The youth accept this categorisation and construct it by deploying several category-bound activities. In this sense, the typical IRF sequence is modified since Dolores asks 
non-known-answer questions, degrading her epistemic status, and the youth respond by showing knowledge and thus by upgrading their epistemic status $[\mathrm{K}+]$. As previous studies have shown, the construction of knowledge and the distribution of epistemic status are not static, but rather topic dependent and negotiated in the interaction (Kasper, 2009; Heritage, 2012; Mondada, 2013). Our data show that, although in pedagogical activities there might commonly be an asymmetry of knowledge (Drew, 1991), when opening them up to include students' expertise, epistemic status $[\mathrm{K}+$ and $\mathrm{K}-]$ might be interactionally distributed and related to the interactional construction of identity. Certainly, the possibility of more equal encounters regarding knowledge and classroom participation seems to implicate valuing youths' linguistic repertoires, which is key especially in multicultural and multilingual educational settings.

All in all, our data show that it is possible and positive to bring plurilingual approaches into classrooms (as for instance Candelier, 2008, proposed) in which students become key actors instead of passively receiving knowledge about languages.

\section{References}

Antaki, C., \& Widdicombe, S. (Eds.). (1998). Identities in talk. London: SAGE.

Candelier, M. (2008). Approches plurielles, didactiques du plurilinguisme: Le même et l'autre. Recherches en didactique des langues et des cultures. Les Cahiers de l'Acedle, 5, 65-90. DOI: $10.4000 /$ rdlc.6289.

Cenoz, J., Gorter, D., \& May, S. (Eds.) (2017). Language awareness and multilingualism. Encyclopedia of Language and Education (3rd ed.). Cham: Springer.

Conteh, J., \& Meier, G. (Eds.). (2014). The multilingual turn in languages education: Opportunities and challenges. Bristol: Multilingual Matters. DOI: 10.21832/978178 3092246.

Cots, J. M., \& Nussbaum, L. (2002). Pensar lo dicho: La reflexión sobre la lengua y la comunicación en el aprendizaje de lenguas. Barcelona: Milenio.

Drew, P. (1991). Asymmetries of knowledge in conversational interactions. In I. Markova \& K. Foppa (Eds.), Asymmetries in dialogue (pp. 29-48). Hemel Hempstead: Harvester Wheatsheaf.

Goodwin, M. H., \& Kyratzis, A. (2011). Peer language socialization. In A. Duranti, E. Ochs, \& B. Schieffelin (Eds.), The handbook of language socialization (pp. 365-390). Hoboken, NJ: Blackwell Publishing.

Hall,J.K., \& Walsh, M. (2002).Teacher-student interaction and language learning. Annual Review of Applied Linguistics, 22, 186-203. DOI: 10.1017/S0267190502000107.

Heritage, J. (2012). Epistemics in action: Action formation and territories of knowledge. Research on Language and Social Interaction, 45(1), 1-29. DOI: 10.1080/ 08351813.2012 .646684$.

Kasper, G. (2009). Locating cognition in second language interaction and learning: Inside the skull or in public view? IRAL, 47, 11-36. DOI: 10.1515/iral.2009.002.

Kellett, M. (2005). Children as active researchers: A new research paradigm for the 21st century? NCRM Methods Review Papers NCRM/003. Southampton: ESRC National 
Centre for Research Methods. Retrieved from: http://eprints.ncrm.ac.uk/87/1/ MethodsReviewPaperNCRM-003.pdf.

Llompart, J. (2016). Pràctiques plurilingües d'escolars d'un institut superdivers: De la recerca a l'acció educativa. (Unpublished $\mathrm{PhD}$ thesis). Universitat Autònoma de Barcelona, Bellaterra.

Markee, N. (2000). Conversation analysis. Mahwah, NJ: Lawrence Erlbaum.

McHoul, A. (1978). The organization of turns at formal talk in the classroom. Language in Society, 7, 183-213.

Mehan, H. (1979). What time is it, Denise?: Asking known information questions in classroom discourse. Theory into practice, 28(4), 285-294. DOI: 10.1080/ 00405847909542846.

Mondada, L. (2013). Displaying, contesting and negotiating epistemic authority in social interaction: Descriptions and questions in guided visits. Discourse Studies, 15(5), 597626. DOI: $10.1177 / 1461445613501577$.

Moore, E., \& Nussbaum, L. (2013). La lingüística interaccional y la comunicación en las aulas. Textos de Didáctica de la Lengua y de la Literatura, 63, 43-50.

Mori,J., \& Zuengler, J. (2008). Conversation analysis and talk-in-interaction in the classroom. In M. Martin-Jones, A. M. de Mejia, \& N. H. Hornberger (Eds.). Encyclopedia of language and education: Vol. 3. Discourse and education (pp. 15-26). New York: Springer. DOI: 10.1007/978-0-387-30424-3_58.

Richards, K. (2006). 'Being the teacher': Identity and classroom conversation. Applied Linguistics, 27(1), 51-77. DOI: https://doi.org/10.1093/applin/ami041.

Rodriguez, L., \& Brown, T. (2009). From voice to agency: Guiding principles for participatory action research with youth. New directions for youth development, 123. DOI: 10.1002/yd.312.

Sacks, H. (1992). The baby cried, the mommy picked it up. In G. Jefferson \& E. A. Schegloff (Eds.), Lectures on conversation (Vol. II, lecture 1 \& 2). Hoboken, NJ: Blackwell Publishing.

Sacks, H., Schegloff, A., \& Jefferson, G. (1974). A simplest systematics for the organization of turn-taking for conversation. Language, 50(4:1), 696-735. DOI: 10.1016/ B978-0-12-623550-0.50008-2.

Seedhouse, P. (2004). The interactional architecture of the language classroom. Oxford: Blackwell.

Sinclair, J., \& Coulthard, M. (1975). Towards an analysis of discourse: The English used by teachers and pupils. Oxford: Oxford University Press.

Stetsenko, A. (2014). Transformative activist stance for education: The challenge of inventing the future in moving beyond the status quo. In T. Corcoran (Ed.), Psychology in education (pp. 181-198). Rotterdam: Sense Publishers.

Stokoe, E. (2012). Moving forward with membership categorization analysis: Methods for systematic analysis. Discourse Studies, 14, 277-303. DOI: 10.1177/ 1461445612441534.

Thomson, P., \& Gunter, H. (2007). The methodology of students-as-researchers:Valuing and using experience and expertise to develop methods. Discourse: Studies in the Cultural Politics of Education, 28(3), 327-342. DOI: 10.1080/01596300701458863.

Waring, H. Z. (2009). Moving out of IRF (Initiation-Response-Feedback): A single case analysis. Language Learning, 59(4), 796-824. DOI: 10.1111/j.14679922.2009.00526.x. 


\title{
Showing attention
}

\section{Student's turn co-construction and other-initiated other-repair}

\author{
Luci Nussbaum
}

\section{Introduction}

This contribution explores a particular case of talk-in-interaction between four students and a teacher who are carrying out a science activity in French, the medium of instruction - as stated in the school curriculum - and a language the students do not employ in their usual environment. It is, by definition, a multilingual situation since the teacher and the students are in front of a computer on whose screen are schematic images accompanied by inscriptions in Catalan. The teacher asks students to explain in French the processes illustrated by the images. In this context, participants can resort to all the semiotic resources at their disposal. Taking a Conversation Analysis (CA) approach, the purpose of this chapter is to illustrate (1) how all these semiotic resources are articulated to construct meaning, (2) how students orient themselves towards the scientific contents by co-constructing their turns, and (3) how the students and their teacher deal with repair.

In the first part of the chapter, we focus on some of the challenges involved in studying classroom situations in which additional languages and other curricular contents are taught; then we present the principles of CA that guide our study. Next, we describe the data and precise the focus used for their exploration. The chapter ends with some final remarks.

\section{Exploring language and content integration in classrooms}

The syntagma 'immersion program' is used to describe a wide range of proposals for teaching curricular contents through a language not commonly used by learners. This didactic approach is 'à géometrie variable' which depends on the social context and on the educational purposes of each particular classroom. Many are the studies that focus on the integration of language and curricular content, but, as Barwell (2005) suggests, their results need to be re-examined critically. For example, Davison and Williams (2001) studied the degree of emphasis that teachers pay on the language or on the content and 
established the following gradation: (1) language teaching; (2) 'contextualised' language teaching; (3) 'simultaneous' integrated language and content teaching; (4) 'language-conscious' content teaching; (5) content teaching. This emphasises that - as Gajo $(2007,2011)$ indicates in his discussions on bilingual education the integration of curricular (non-linguistic) and linguistic content is a local phenomenon observable throughout the interaction. Along this line, Seedhouse (2004) points out that there is a reflexive relationship between pedagogy and interaction. Then, whether the focus of instruction is on the content or on the language will be observable in the teaching actions. As we will see, in our data, the teacher puts her emphasis on teaching content; and only on a few occasions she focuses on language forms. Therefore, students are mainly content oriented, too.

Hutchby and Wooffitt (1998) highlight - and as Seedhouse (2004) emphasises for classrooms situations - there are two crucial questions in CA we need to pose: (1) what are the interlocutors doing? and (2) with what resources do they orient to those actions? In this sense, CA considers interaction as a social sequentially identifiable action, performed with verbal and other semiotic resources at a given time. Therefore, CA concepts of turn-taking, sequence, preference and repair explain how speakers socially construct the meaning of what they are doing. Turns in classroom discourse are typically organised in a three-part sequence. Many authors (see McHoul, 1978, 1990, among others) have pointed out that a recurring sequence of the interaction between the teacher and their students is formed by adjacency triads QAC (QuestionAnswer-Comment), the third turn being a comment on, an acceptance of, or a rejection of the student's answer in the second turn. The notion of preference is socially rooted, since it fundamentally alludes to the fact that, in every interaction, there are sequentially preferential behaviours. Thus, in our data, students seek to provide an answer to the teacher's third turn when she does not accept their second turn, in the same way that they are clearly oriented towards the language of instruction, as we will see. Finally, the concept of repair - mechanism by which interlocutors treat what is perceived as an obstacle in the construction of meaning or as a deviant form regarding the language that is being used - is crucial for the study of the interactions in which curricular contents are delivered in an additional language, given the double attention that students have to pay to what is being said and, at the same time, to the necessary resources to do so. Therefore, examining who repairs and when is essential.

Classroom interaction has often been considered to resemble the interaction between adults and children, in which other-initiated other-repair sequences seems to prevail, contrary to what happens in the conversation between adults. But, in some cases, as in classroom peer group interactions, there is a preference for self-correction, other initiated or self-initiated repairs, as Masats (2017) points out. This author also indicates that there are different objects of repair sequences. As we will see, in our data, teacher and students are mainly involved in content repair sequences, although correction movements regarding linguistic 
forms also emerge. Interesting for our data is the type of repair sequence, found by McHoul (1990), in which teachers indicate unacceptable student answers without providing direct corrections. The author uses the term "cluing" to refer to this procedure of attempting to lead students to self-correct answers by small steps. Following Schegloff, Jefferson, and Sacks (1977), McHoul (1990) also states that to examine repair sequences in the classroom it is necessary to observe the itineraries in which they occur (see Macbeth, 2004, for a discussion on repair itineraries). These trajectories have their beginning at the moment the problem is marked until the correction or the replacement of an item takes place. Repair is a sequential phenomenon, while corrections are only part of the sequence or simply a replacement of an utterance by another one. Therefore, Schegloff, Jefferson, and Sacks (1977) refer to the sequential phenomenon as repair and to correction as a movement in which one or more elements are replaced.

As Barwell $(2003,2005)$ suggests, another key notion to understand the process of language and content integration is that of 'attention'. This concept -emblematic in CA (Sacks, Schegloff, and Jefferson, 1974; Schegloff, 1984) - allows taking into account what participants focus on during the interaction and to understand how attention is reflexively related to what it has been said before and to what will be said later. As Schegloff (1984:37) points out:

[C]o-participants in conversation operate under the constraint that their utterances be so constructed and so placed as to show attention to, and understanding of, their placement. That means that utterances, or larger units, are constructed to display to co-participants that their speaker has attended a last utterance, or sequence of utterances, or other unit, and that this current utterance, in its construction, is placed with due regard for where it is occurring.

Attention can be particularly observable in preceding turn completion. In this sense, in different works, Lerner $(2002,2004)$ shows that participants can choose either to complete a part of the turn construction unit (TCU) of the current speaker, or to co-formulate a turn's completion (choral co-production). The co-construction of talk-in-interaction allows participants to carry out affiliative and disaffiliative actions (Pomeranz, 1984; Heritage, 2008, among others) to ensure the production of meaning. In the case we analyse, the completion of utterances started by the previous student indicates that the student who completes the turn is simultaneously (1) paying attention to the question asked by the teacher, (2) interpreting the images and inscriptions that appear on the computer screen, and (3) understanding the utterance the preceding speaker has formulated. This involves attention not only to meaning but also to sequential, syntactic, pragmatic and semantic aspects of on-going speech (PiirainenMarsh, 2011). These practices are sensitive to the interactional environment in which they occur and to the semiotic resources available to coordinate actions 
(Goodwin and Goodwin, 2004; Lerner, 2004), including the use of language alternations and/or of hybrid forms. As previous works conducted by the authors of this volume highlight, these plurilingual resources act as scaffolding mechanisms that enable student's participation in classroom activities (see, for example, Masats, Nussbaum, and Unamuno, 2007; Llompart et al, 2020).

\section{Data and approach}

The data presented in this chapter was collected at a primary school where Catalan is the main language of instruction, although Spanish, English and French are also used in different curricular spaces (see Moore and Nussbaum (2011) and Nussbaum $(2013,2017)$ for other focuses of analysis of these data). We analyse the case of a group of ten-year-old children who started learning French a year before taking the course on science through French we examine here. Our data comprises the total length, 3' and 20", of a fragment of interaction recorded through a camera located next to the teacher, which explains why she is left out of the image. In the transcription we have only indicated the 'non-French' forms when they are object of attention by the current speaker or by the next one.

While the rest of the students in the class are doing individual tasks in the computers room, the teacher and four students (Lara, Bernat, Luisa and Sofia) are in front of a computer on whose screen the following question is written: "Els animals i les plantes necessiten energia per viure. Com s'ho fan per aconseguir-la?" (Animals and plants need energy to live. How do they manage to get it?). Below the question there are schematic images of plant breathing and nourishing processes accompanied by inscriptions in Catalan. Figure 6.1 shows the arrangement of the group, as well as the gaze and position of the children's body oriented towards the screen. Sometimes, however, throughout the interaction, the students turn their gaze and body towards the teacher, as we will see in the analysis.

The interaction revolves around the review of contents that had already been discussed in other sessions. The teacher wants these students to conceptualise certain processes of a plant life cycle and then be able to explain the phenomena in French to the rest of the class. The activity falls into what Williams (1994) referred to as 'translanguaging' and Duverger (2007), in his proposal for the 'didactisation of plurilingualism', conceptualised as 'meso alternation': the consecutive use of different languages within a didactic sequence. Noguerol and his team proposed similar approaches for the Andorran curriculum (see Martínez et al, 2019). It is therefore a complex activity that involves both the understanding of certain processes and their formulation in French. As we will see, students focus on this language as the medium of interaction (Gafaranga, 2009) and, only in two moments, a medium suspension emerges (Gafaranga \& Torras, 2001), that is, a non-sequentially implicative switch, in our case to Catalan. For the analysis of the available data, we will pay particular attention 


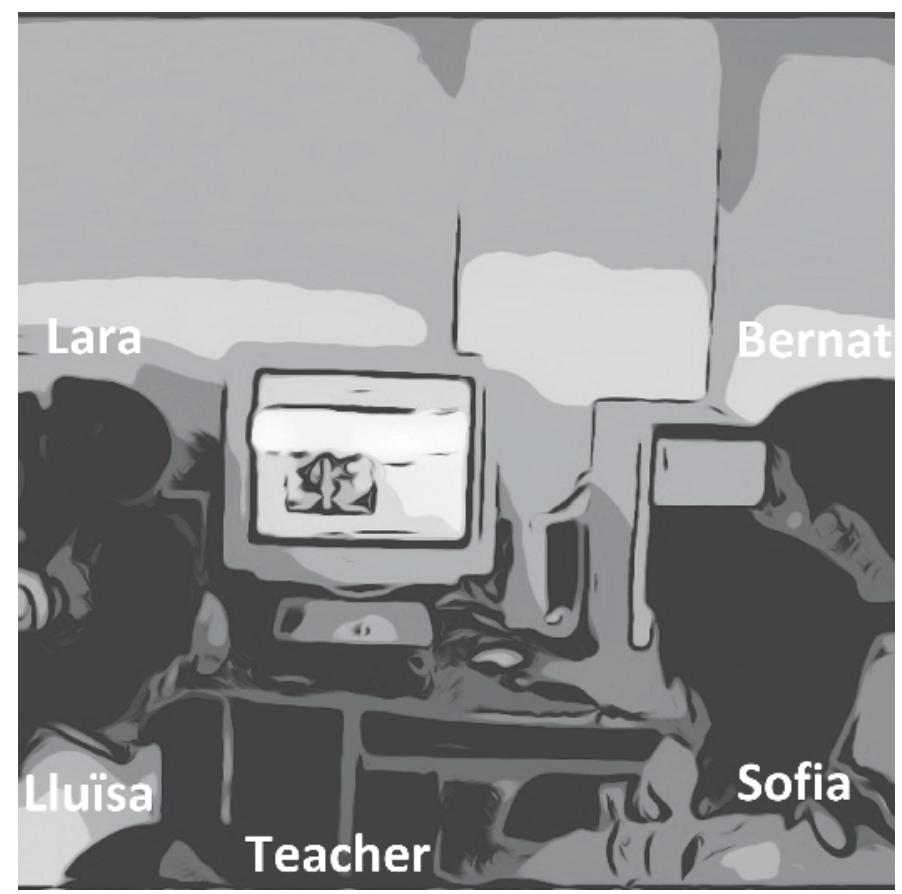

Figure 6.I Seating arrangement

to three phenomena: (1) the student's co-construction of utterances, (2) the teacher's third turn and (3) the trajectories of repair.

\section{Analysis and discussion}

The video begins when the teacher asks the four students what the image on the computer screen means (see Figure 6.2).

Excerpt 1. Participants:The teacher (ENS) and three of students, Bernat (BER), Lara (LAR), Luisa (LLU)

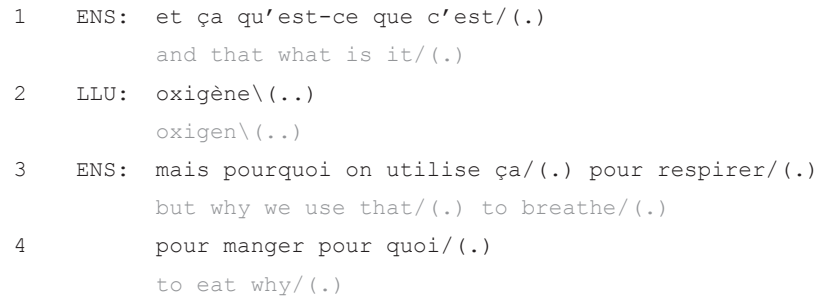




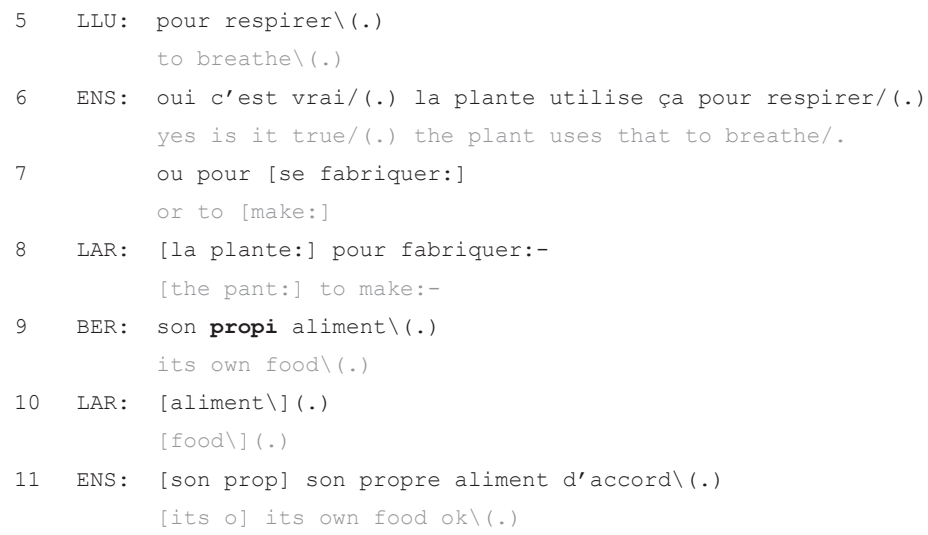

In line 1 , the teacher, as verified later in line 3, asks for a process shown in the diagram on the computer screen. LLU names one element ("oxygen") in her answer (line 2). Then, the teacher expands her question (lines 3 and 4). LLU answers (line 5), but the teacher does not accept her answer and begins to formulate an alternative question (lines 6 and 7), as a clue looking for a repair on LLU's answer. LAR begins to respond in an overlapping turn with the

\section{Els animals i les plantes necessiten energia per viure. Com s'ho fan per aconseguir-la?}

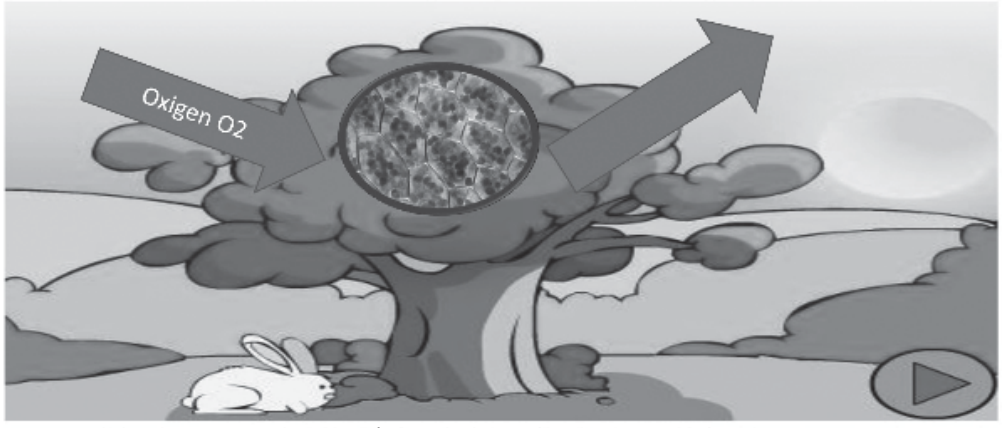

Activity from. www.edu365.cat/primaria. Interactive Designer: Moluanda. Script: Cristina Rafecas, Joan Garín, Ramon Grau, Montserrat Sànchez.

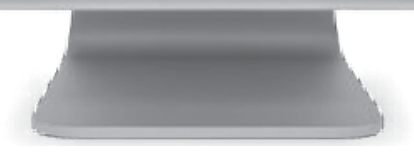

Figure 6.2 Reproduction of the text and pictures children could see on their computer screen 
teacher (line 8), but BER, taking advantage of LAR's hesitation (she lengthens the last word she utters) and completes LAR's turn (line 9). LAR then uses the last part of BER's turns to complete her proposal (line 10). The teacher accepts the co-constructed answer (line 11) and, at the same time, embeds a covered correction of the word "propi" formulated by BER and closes the repair sequence (line 11). Then, in the same turn, the teacher wants the students to explain the breathing process, as seen in line 12 below.

Excerpt 2. Participants:The teacher (ENS) and the four students, Bernat (BER), Lara (LAR), Luisa (LLU) and Sofia (SOF)
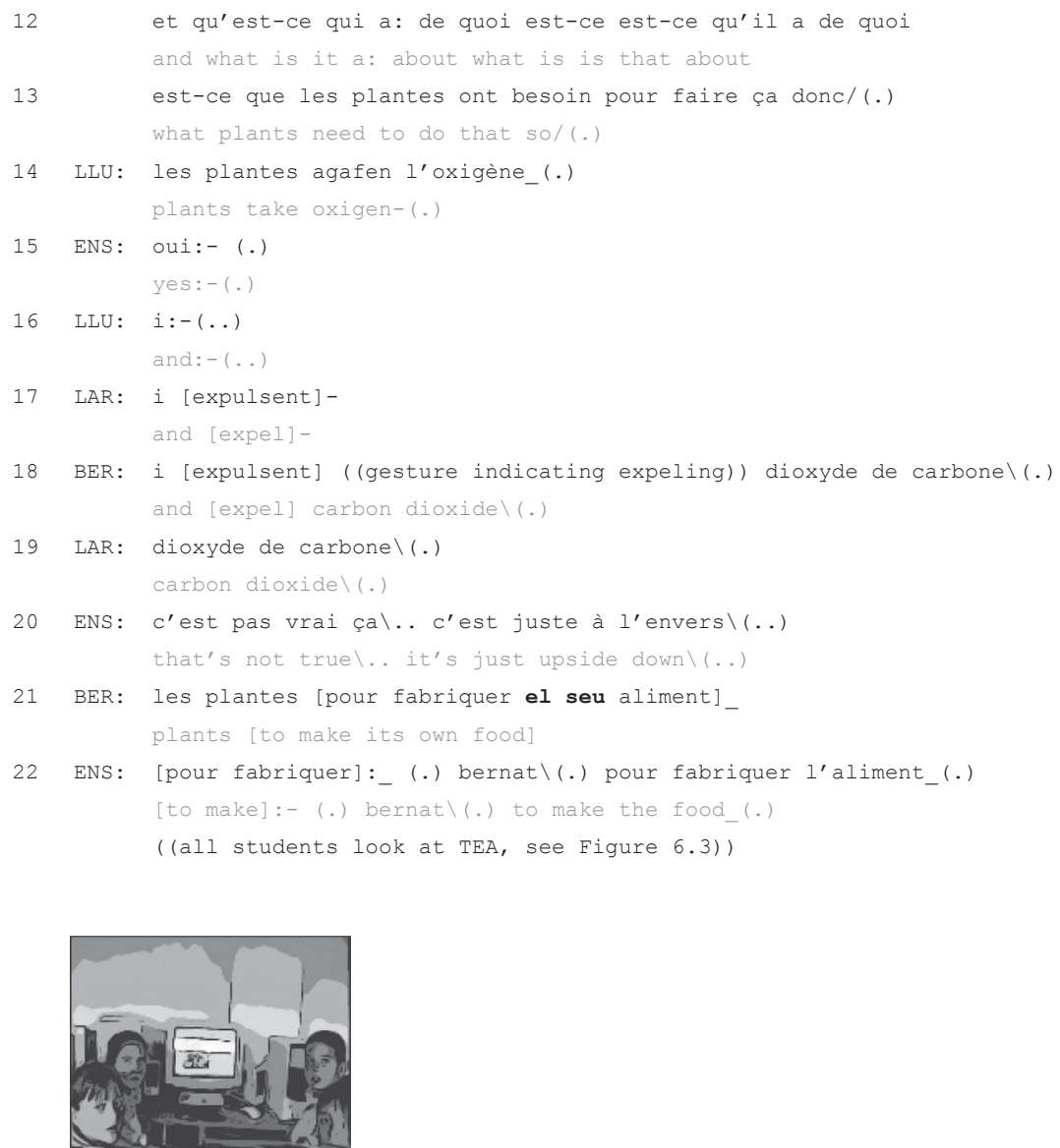

Figure 6.3 The students turn to the teacher 
elles prennent quoi/ (.) ((door noise)) elles prennent quoi/.

they take what/(.) ((door noise)) what do they take/(.)

( (a person is talking to someone aloud and the recording stops)

24

ENS: allez\(.)

come on $\backslash($.

BER: C'est à l'envers-(.) les plantes fabriquent el seu aliment

it's just upside down-(.) plants make their food

à partir de $l^{\prime}$ ar de $l^{\prime}$ ar $i \operatorname{xxx} \backslash(.) \operatorname{xxx} \mathrm{xxx}-($.

from the air air and $\mathrm{xxx} \backslash$. $\mathrm{xxx} \times \mathrm{xxx}-$.

ENS: mais pourquoi vous lisez pourquoi vous lisez/(.)

but why arew you reading why are you reading/(.)

expliquez expliquez aux autres $\backslash$. ne lisez pas $\backslash($.

explain explain to others $\backslash$. do'nt read $\backslash$.

LLU: les plantes:-

plants :-

ENS: oui $\backslash($.

yes $\backslash($.

LAR: eh:.fabriquent-(.)

eh: . make-(.)

ENS: oui $\backslash($.

yes $\backslash($.

LLU: ses propis aliments: - (.) ((looking at TEA))

their own food:-(.)

ENS: d'accord: \(..) avec quoi/(..) (noises) avec quoi/(..)

ok: $\backslash(\ldots)$ whith what/ (..) [(noises) ] with what/(..)

LLU: $m:(\ldots)$

$m:(\ldots)$

ENS: avec e: de [l'eau/]

whit e: [water/]

BER: [i les plantes]: e:(.) respirer $\backslash($.

[and plants]: e: (.) breath $\backslash($.

ENS: non non on est en train de parler de l'alimentation hein/(..)

no no we're talking about food huh/(..)

( (all students look at TEA))

BER: $\quad x \times x-(\ldots)$

ENS: de quoi est-ce qu'elles s'alimentent les plantes/(.)

what do plants eat/(.)

LLU: de l'air- (.) [de l'eau]

from air_(.) [from water]

LAR: [de $l^{\prime}$ eau ]

[from air]

ENS: de l'eau d'accord l $^{\prime}($ )

from water ok $\backslash$.

BER: de l'eau dioxyde de carbone:-

from water carbon dioxide:- 

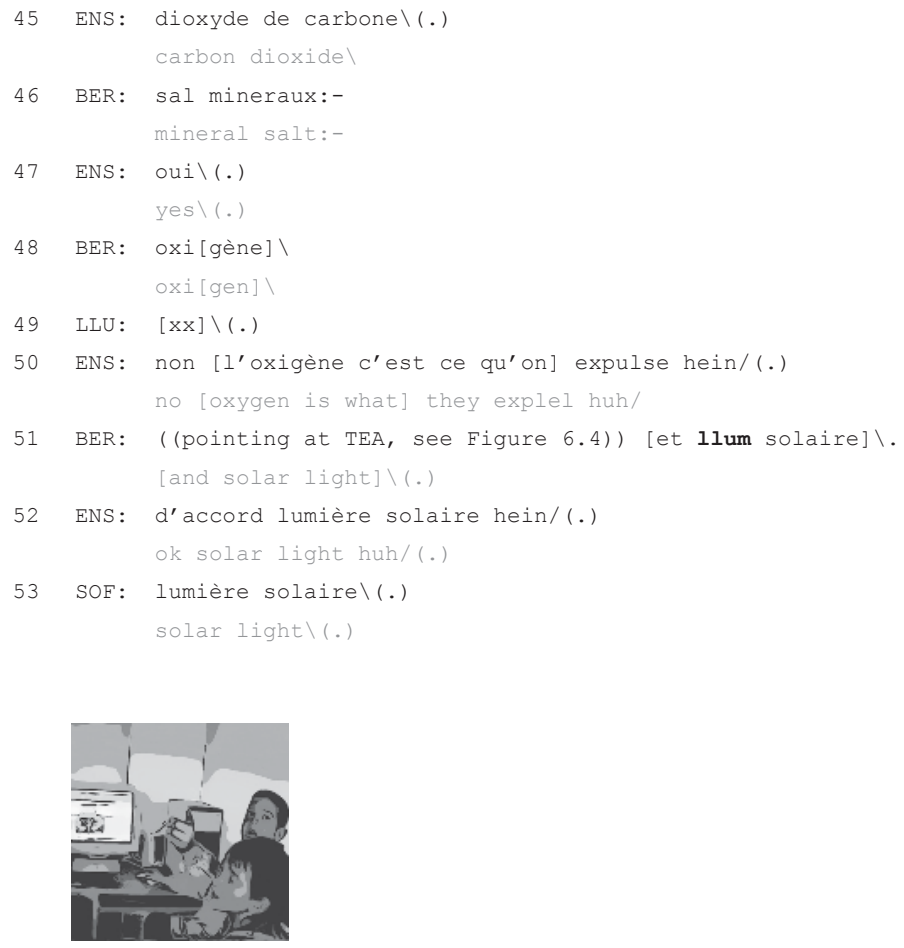

Figure 6.4 Bernat points at the teacher

LLU initiates an answer (line 13) and the teacher, as LLU interrupts herself, encourages her to continue (line 15), which she does, but she pauses again (line 16). Then LAR takes the floor (line 17), but BER, in an overlapping turn that reproduces parts of LAR's contribution, formulates a complete answer (line 18). Again, it is interesting to point out that the co-constructed response by LAR and BER denote the attention of the two students to the ongoing talk. The teacher indicates that the answer is wrong and initiates a repair sequence with the clue "c'est juste à l'envers" (It's just the opposite, line 20). BER attempts to paraphrase the co-constructed answer taking into account the teacher's remark (line 21). The teacher then addresses BER and reformulates his previous answer and, at the same time, she corrects on the fly "el seu" (line 22). An adult person who enters the classroom and asks for something aloud interrupts the interaction. When it restarts, the teacher asks students to continue. Interestingly, BER takes up the teacher's previous statement (line 20: "c'est juste à l'envers") to initiate his answer with "c'est à l'envers," followed by an incomprehensible fragment (lines 25-26). But the teacher, strangely, asks the students why they read, although the students do not because the utterances they produce are not 
written on the screen. She instructs them not to read and tells them that they have to explain the phenomenon (lines 27 and 28). LLU starts an explanation, encouraged by the teacher (lines 29-30). LAR adds a verb and the teacher incites her to proceed (lines 31-32); LLU continues by recycling an utterance previously produced (in lines $8-10$ ) by LAR and BER. The teacher accepts and asks students which elements plants use (lines 34 and 36). LLU hesitates (line 35), but BER initiates an answer introducing the word "respirer" (line 37). The teacher interrupts him saying that they are talking about food (line 38). BER produces some incomprehensible words (line 39) and the teacher asks the group about what plants eat (line 40). LLU and LAR then propose elements that serve to feed plants (lines 41, 42, 44 and 46), which the teacher accepts (lines 43, 45 and 47) until BER proposes "oxygen" (line 48) and LLU says something incomprehensible (line 49), which is not accepted by the teacher (line 50). BER adds the proposal "llum solaire" (solar light, line 51) by mixing two codes, Catalan and French. He does so while pointing at the teacher (see Figure 6.4), who accepts his proposal by paraphrasing it in French in the next turn. Then, SOF - who has been silent until now - repeats it, aligning herself with the teacher's correction (line 53).

Various phenomena can be remarked in excerpt 2. Firstly, we observe the long repair content sequence initiated by the teacher in her C turn (line 20). Second, we note the students' orientation towards the medium of instruction. From an etic perspective, hybrid forms appear, but, in general, these are not focused by the students or by the teacher (despite her embedded correction in line 52 and the repetition of one of these forms by SOF, in line 53) and therefore are not analysed here. Third, we see children's attention focussed on the life processes of plants that the images illustrate and the teacher emphasises. This is particularly evident in those cases in which one of the students is responsible for the completion of the utterances started by another student (lines 29 and 33 ) or in which meaning is co-constructed in choral-produced TCUs (lines 41, 42).

In the next excerpt, the teacher formulates another question to elicit from students what other sources of energy plants need (lines 54-55).

Excerpt 3. Participants: The teacher (ENS) and two of the students, Bernat (BER), Lara (LAR)

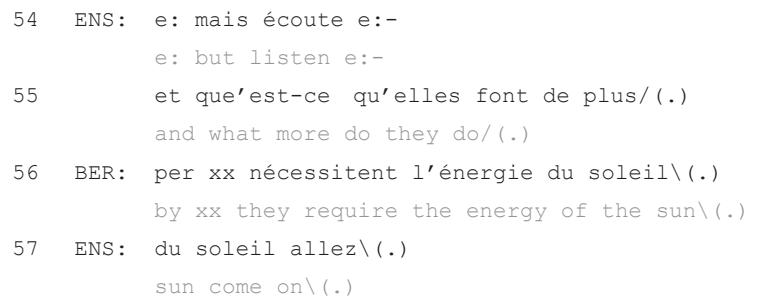



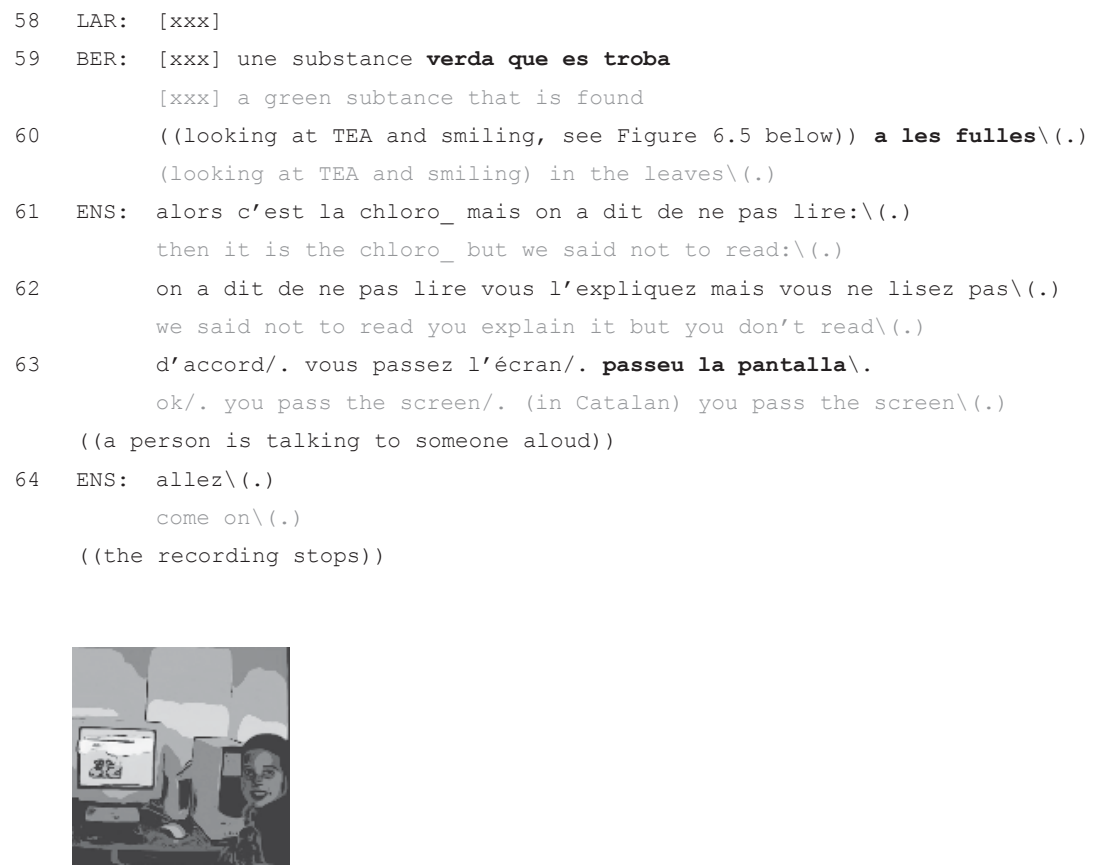

Figure 6.5 Bernat looks at the teacher and smiles

In this excerpt, BER proposes a complete utterance, which the teacher accepts, while encouraging him to continue (lines 56-57). LAR says something incomprehensible and BER adds an utterance in Catalan, looking at the teacher and smiling (lines 59-60; see Figure 6.5). BER's smile in producing some words in Catalan could be interpreted as a sign he is excusing himself for disaffiliating from the language of instruction. The teacher begins her turn by making reference to the term "chlorophyll," but interrupts it (line 61) to remind students again that they are not expected to read, but to explain the process to the other students. Then she asks them to change the information on the screen, first in French and then in Catalan (lines 61-63). Again, the voice of an adult person is heard speaking to someone in the room and the teacher calls for attention. At this point the recording is interrupted. Regarding the linguistic resources in this excerpt, the teacher's medium suspension (Gafaranga, 2007) on line 63 is just outside the content of the activity.

In excerpt 4 below, we observe that SOF, who until that moment had not been verbally active (except for her turn in line 53 when she repeats a correction made by the teacher), is particularly attentive to the formal aspects of language and corrects the hybrid forms produced by their peers. 
Excerpt 4. Participants: The teacher (ENS) and the four students, Bernat (BER), Lara (LAR), Luisa (LLU) and Sofia (SOF)

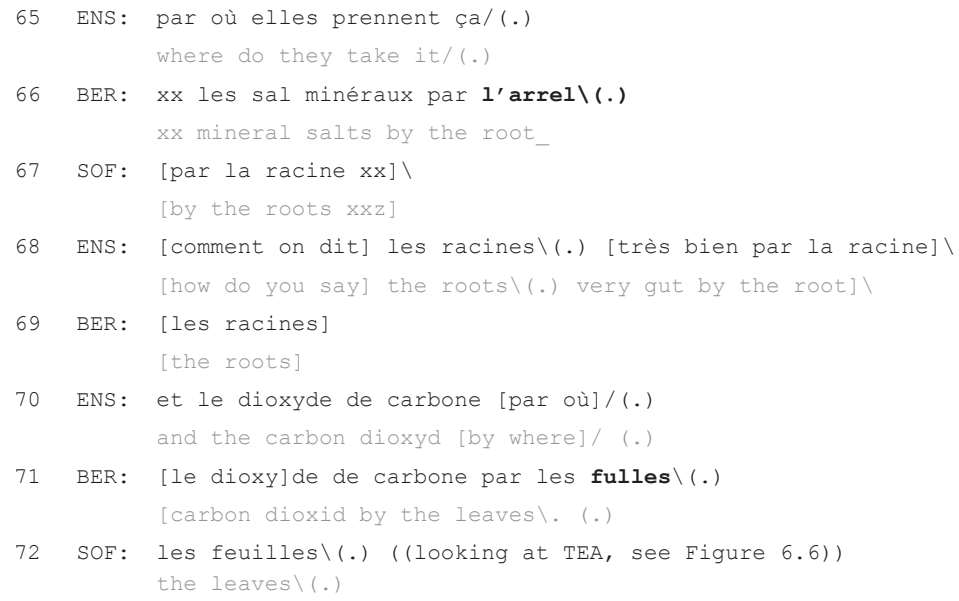

\section{Figure 6.6 Sofia looks at the teacher}




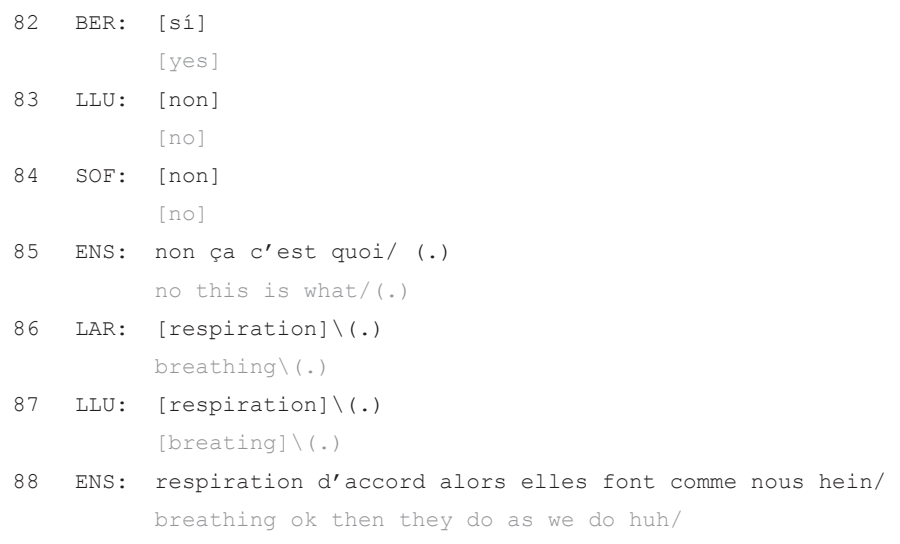

As noted, after BER's explanation in line 66, SOF immediately corrects the word "arrel" (root) at the same time that the teacher initiates a repair sequence requesting the word in French (lines 67 and 68). In line 72, SOF corrects the word "fulles" (leafs), used by BER in the previous turn and taken up again by LAR, after the teacher's acceptance of SOF's correction (lines 73-77). Once again, choral-produced TCUs are observed here in response to the teacher's questions, in lines 81-84 and 86-87.

\section{Conclusions}

As has been indicated, students in a science class conducted through French carry out a complex task consisting of answering the questions formulated by the teacher in French while, at the same time, they look at two slides depicting phenomena related to the life of plants, which are accompanied by inscriptions in Catalan. Our analysis of the data reveals that both teachers and students are oriented towards the science contents. There are no instances in which students show that the form of the contents is 'opaque' and that, therefore, it is not necessary to treat them through 're-mediation' procedures (Gajo, 2007, 2011), using other languages that they master better.

The interaction is structured in $\mathrm{Q}-\mathrm{A}-\mathrm{C}$ sequences, which give rise to interesting phenomena. In the first place, the co-construction of turn A (Answer) is a recurring event, in the form of either completions of a turn initiated by the previous student or choral responses (Lerner, 2004). This demostrates attention, not only towards the question formulated by the teacher and towards the information offered by the screen, but also towards the preceding turn formulated by another student. Second, turn C (Comment) produced by the teacher can signal either her acceptance of turn A or her disapproval. In this latter case, she opens the space to repair sequences of turn A (whether individual or collective). She uses 'clues' (McHhoul, 1990) to lead students to self-correct their previous turn A, which they always try, maintaining the fluidity of the interaction. 
Regarding the use of linguistic resources, French is the medium of interaction (Bonacina and Gafaranga, 2011). Students orient themselves towards the use of the language of instruction, trying 'doing being French speakers', and sometimes correcting lexical forms produced by their classmates, in the subsequent turn. At certain moments, the teacher corrects some linguistic forms on the fly. But these corrections are unnoticed by the students. Only once does she open a repair sequence of linguistic forms. Thus, as Barwell (2005) points out, language and content integration relates to the social activity students are engaged in. In our data, students are active agents of their participation in the co-construction of scientific content.

\section{Acknowledgments}

We are grateful to Isabel Camacho for her generosity in making the video from which we extracted the data in this chapter available to us.

\section{References}

Barwell, R (2003). Patterns of attention in the interaction of a primary school mathematics student with English as an additional language. Educational Studies in Mathematics, $53,35-59$.

Barwell, R. (2005). Integrating language and content: Issues from the mathematics classroom. Linguistics and Education, 16, 205-218.

Bonacina, F., \& Gafaranga, J. (2011). 'Medium of instruction' vs. 'medium of classroom interaction': Language choice in a French complementary school classroom in Scotland. International Journal of Bilingual Education and Bilingualism, 14(3), 319-334.

Davison, C., \& Williams, A. (2001). Integrating language and content: Unresolved issues. In B. Mohan, C. Leung, \& C. Davison (Eds.), English as a second language in the mainstream: Teaching, learning and identity (pp. 51-69). Harlow: Longman.

Duverger, J. (2007). Didactiser l'alternance des langues en cours de DNL. Tréma, 28, 81-81. DOI: $10.4000 /$ trema.302.

Gafaranga, J. (2007). Talk in two languages. Houndsmills: Palgrave Macmillan.

Gafaranga, J. (2009). The conversation analytic model of code-switching. In B. E. Bullock \& A. J. Toribio (Eds.), The Cambridge handbook of linguistic code-switching (pp. 114-121). Cambridge: Cambridge University Press.

Gafaranga, J., \& Torras, M.C. (2001). Language versus medium in the study of bilingual conversation. International Journal of Bilingualism, 5(2), 195-220.

Gajo, L. (2007). Linguistic knowledge and subject knowledge: How does bilingualism contribute to subject development? International Journal of Bilingual Education and Bilingualism, 10(5), 563-581.

Gajo, L. (2011). Trabajar en otra lengua para elaborar saberes en una disciplina. In C. Escobar \& L. Nussbaum (Eds.), Aprendre en una Altra llengua / Learning through another language / Aprender en otra lengua (pp. 53-70). Bellaterra: Servei de publicacions de la UAB.

Goodwin, C., \& Goodwin, M. H. (2004). Participation. In A. Duranti (Ed.), A companion to linguistic anthropology (pp. 222-244). Oxford: Blackwell. 
Heritage, J. (2008). Conversation analysis as social theory. In B. S. Turner (Ed.), The new Blackwell companion to social theory (pp. 300-320). Oxford: Blackwell.

Hutchby, I., \& Wooffitt, R. (1998). Conversation analysis. Cambridge: Cambridge University Press.

Lerner, G. (2002). Turn-sharing: The choral co-production of talk in interaction. In C. Ford, B. Fox, \& S. Thompson (Eds.), The language of turn and sequence (pp. 225-256). Oxford: Oxford University Press.

Lerner, G. (2004). Collaborative turn sequences. In G. Lerner (Ed.), Conversation analysis: Studies from the first generation (pp.225-256). Amsterdam: John Benjamins.

Llompart, J., Masats, D., Moore, E, \& Nussbaum, L. (2020). Mézclalo un poquito. International Journal of Bilingual Education and Bilingualism, 23(1), 98-112.

Martínez, M, Masats, D. Noguerol, A., Nussbaum, L., Pujol, B. Rabassa, P., \& Roig Rotllan, E. (2019). Programa de llengües $i$ literatures de segona ensenyança de l'Escola Andorrana. Govern d'Andorra: Ministeri d'Educació i Ensenyament Superior. Retrieved from https://www.educacio.ad/images/stories/estudis/2aEnsenyanca/ Prog2Ense_Llengues.pdf.

Macbeth, D. (2004). The relevance of repair for classroom correction. Language in Society, 33(5), 703-736.

Masats, D. (2017). Conversation analysis at the service of research in the field of second language acquisition (CA-for-SLA). In E. Moore \& M. Dooly (Eds.), Qualitative approaches to research on plurilingual education / Enfocaments qualitatius per a la recerca en educació plurilingüe / Enfoques cualitativos para la investigación en educación plurilingüe (pp. 321-347). Dublin/Voillans: Research-publishing.net. DOI: 978-1-908416-47-6/633.

Masats, D., Nussbaum, L., \& Unamuno;V. (2007). When the activity shapes the repertoire of second language learners. In L. Roberts, A. Gürel, S. Tatar, \& L. Marti (Eds.), EUROSLA Yearbook 7 (pp. 121-147). Amsterdam: John Benjamins.

McHoul, A. W. (1978). The organization of turns at formal talk in the classroom. Language in Society, 7, 182-213.

McHoul, A. W. (1990). The organization of repair in classroom talk. Language in Society, 19, 349-377.

Moore, E., \& Nussbaum, L. (2011). Què aporta l'anàlisi conversacional a la comprensió de les situacions d'AICLE. In C. Escobar \& L. Nussbaum (Eds.), Aprendre en una Altra llengua / Learning through another language / Aprender en otra lengua (pp. 93-117). Bellaterra: Servei de publicacions de la UAB.

Nussbaum, L. (2013). Interrogations didactiques sur l'éducation plurilingue. In V. Bigot, A. Bretegnier, \& M. Vasseur (Eds.), Vers le plurilinguisme? 20 ans après (pp. 85-93). Paris: Albin Michel.

Nussbaum L. (2017). Doing research with teachers. In E. Moore \& M. Dooly (Eds.), Qualitative approaches to research on plurilingual education / Enfocaments qualitatius per a la recerca en educació plurilingüe / Enfoques cualitativos para la investigación en educación plurilingüe (pp. 46-67). Dublin/Voillans: Research-publishing.net. DOI: 10.14705/ rpnet.2017.emmd2016.621.

Piirainen-Marsh, A. (2011) Enacting interactional competence in gaming activities: Coproducing talk with virtual others. In J. K. Hall, J. Hellermann, \& S. Pekarek Doehler (Eds.), L2 interactional competence and development (pp.19-44). Bristol: Multilingual Matters. 
Pomerantz, A. (1984). Agreeing and disagreeing with assessments: Some features of preferred/dispreferred turn shapes. In J. M. Atkinson \& J. Heritage (Eds.), Structures of social action: Studies in conversation analysis (pp. 57-101). Cambridge: Cambridge University Press.

Sacks, H., Schegloff, E. A., \& Jefferson, G. (1974). A simplest systematics for the organization of turn-taking for conversation. Language, 50(4), 696-735.

Schegloff, E. A. (1984). On some questions and ambiguities in conversation. In J. M. Atkinson \& J. Heritage (Eds.), Structures of social action: Studies in conversation analysis (pp. 28-52). Cambridge: Cambridge University Press.

Schegloff, E. A., Jefferson, G., \& Sacks, H. (1977). The preference for self-correction in the organization of repair in conversation. Language, 53, 361-382.

Seedhouse, P. (2004). The interactional architecture of the language classroom: A conversation analysis perspective. Malden, MA: Blackwell.

Williams, C. (1994). Arfarniad o ddulliau dysgu ac addysgu yng nghyd-destun addysg uwchradd ddwyieithog [An evaluation of teaching and learning methods in the context of bilingual secondary education]. (Unpublished doctoral thesis). Prifysgol University, Bangor. 


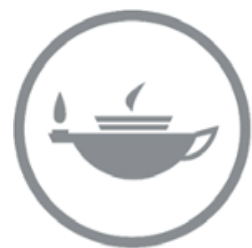

Taylor \& Francis Taylor \& Francis Group http://taylorandfrancis.com 
Students as plurilingual sociolinguists 


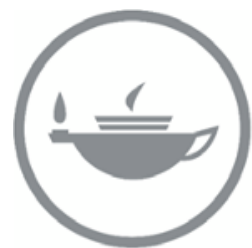

Taylor \& Francis Taylor \& Francis Group http://taylorandfrancis.com 


\title{
Building the sociolinguistic environment through talk-in-interaction
}

\author{
Virginia Unamuno
}

\section{Introduction}

In this chapter we focus on how patterns of language alternation are constructed collectively by two learners during their participation in two pedagogical tasks, one through English and the other one through Catalan. Choosing a language and switching to and from a language are procedures participants employ as resources to make sense of their actions (Gumperz, 1982; Auer, 1984). Through talk-in-interaction students build the social and discursive context in which their language choices and alternation make sense.

During our ethnographic fieldwork we could observe that Spanish emerged as a lingua franca in informal conversations in and out of classrooms, but also that in the classroom learners also orient towards the 'medium of instruction' (Gafaranga, 2000). Kunitz and Markee (2016) point-out that Ethnography of Communication does not offer methodological precisions for deciding which aspect(s) of context may legitimately be used to interpret what happens at every moment in a particular interaction. In this sense, it may be useful to combine the broad perspective of the sociolinguistic environment documented by the ethnographic field work with a narrower sequential analysis of talk-in-interaction.

Gumperz's notion of contextualisation cues (1982) is crucial in this regard. It offers the possibility of examining the speakers' orientations during the coconstruction of the tasks at hand and of observing the linguistic resources used during interactional activities. In plurilingual conversation, language choices and language alternations are one of these contextualisation cues, as they signal modifications in the course of the interaction. As our data was collected in schools, milieus where language policies determine which languages are to be used as means of instruction and communication in the classrooms, we could argue that those policies have an impact on learners' language choices. However, we will illustrate this is not always the case. Our analysis will demonstrate that the study of language alternation could explain how learners envisage their participation in the two tasks we study here. 


\section{Our perspective of analysis}

The GREIP team designed sequences of three types of pedagogical tasks (a two-way information-gap task, a problem-solving task and a role play) which were used as tools to collect data of pair work interaction. In the first project the same tasks were carried out by L2 learners of English (in primary classrooms), French (in secondary classrooms) and Spanish (in university classrooms with adult ERASMUS students). During the development of the second project similar tasks were implemented in primary and secondary classrooms that hosted a high percentage of students of immigrant origin in order to capture their language socialisation (see Nussbaum and Unamuno, 2006). Describing the results of those projects is beyond the objectives of this chapter; however, two of the findings are relevant for the analysis of the data we present here. First, it could be noted that recording devices took a key role as another participant in the interaction among the pairs of students, as we will observe in excerpt 1. Second, we could notice that, when working in pairs, learner's interaction is organised in adjacency pairs (and not in IRF - Initiation, Response, Feedback sequences as in teacher-directed interaction) and relies on repair procedures of both the linguistic forms and of the development of the tasks in progress (Masats, 1999; Masats at al, 2000; Nussbaum and Unamuno, 2000; Masats and Unamuno, 2001; Unamuno and Nussbaum, 2005; Masats, Nussbaum, and Unamuno, 2007; Unamuno, 2008).

In a previous study (see Unamuno, 2011), the same corpus was analysed to explore the processes of language socialisation at schools. We observed that, during the execution of pedagogical tasks carried out in pairs, students of immigrant origin made use of the prevailing sociolinguistic patterns in the context of their school community. The appropriation of those patterns was guided by teachers, but especially by their peers who, through interaction, gave them information about patterns of language use. Social participation also enabled students of immigrant origin to 'become' ratified members of the community of practice (Lave and Wenger, 1991) their fellow students belonged to at school. In this chapter, we re-examine these findings and we focus on learners' active role in the sequential co-construction of the interactional context via language choices and alternations. To do so, we will base our study on the concept of contextualisation cue (Gumperz, 1982) as employed in studies in the field of Interactional Sociolonguistics (Gumperz, 1999; Rampton, 2017).

In this chapter, language alternation is seen as a cue that signals when one participant in a communicative event indicates the others that something is changing in the course of the interaction (Gumperz, 1982). Along this line, Auer (1984) stresses the importance of analysing code-switching sequentially in order to elucidate if language alternation is 'discourse-related' or 'participantrelated'. Consequently, we will provide a sequential analysis (Seedhouse, 2004; Markee, 2005) of our data and will subscribe Gafaranga's (2000) view that the 
'medium of interaction' is constructed by participants and may not coincide with the 'medium of instruction' (Bonacina and Gafaranga, 2011). Thus, the 'medium of interaction' may be based on language alternation, as we will see in the two excerpts we examine here. This coincides with the idea put forward by Lüdi and Py (1986 [2002]; 2009), who point out that in multilingual settings participants may orient towards 'unilingual' modes of communication (they attempt to communicate in one language) or towards 'plurilingual' modes (they employ resources from a variety of languages). Our data reveals the relevance of taking into account both modes. Therefore, we suggest that the study of language alternation as a resource to create and interpret the context in talkin-interaction offers hints on how participants build the sociolinguistic environment in which their actions take place, in a fluid plurilingual mode.

\section{Methodology}

Between 2002 and 2006 the Research Centre for Plurilingual Education \& Interaction (GREIP) conducted a research project aimed at investigating the uses, practices, and linguistic identities displayed by children of immigrant origin while learning the languages taught at school: Catalan, Spanish, and English (see Nussbaum and Unamuno, 2006). The two excerpts we will analyse here are part of this broader corpus obtained in various primary and secondary schools in Catalonia. In this particular case we examine tasks that are the product of a collaborative study conducted by the GREIP team and a primary school teacher. For a period of two days, several pairs of students carried out three types of tasks mentioned above. Catalan is the language of instruction in schools in Catalonia, and Spanish and English are taught either as subject matter or as vehicular languages to teach other contents.

In this chapter, we will analyse two pieces of talk-in-interaction obtained in the English class (excerpt 1) and in the Catalan class (excerpt 2), while two students, Haffi and Raül, were engaged in the tasks of spotting differences between two pictures (excerpt 1) and of scripting a dialogue (excerpt 2). Occasionally, Cecilia, the researcher, and the person responsible for conducting the tasks in that school take part in the conversation. Part of the instructions of the tasks involves making clear which language student should use. Also, Cecilia explains orally that the tasks must be carried out in the target language (English in the first case and Catalan in the other case). Interactions were tape-recorded and transcribed.

\section{Analysis and discussion}

Our analysis examines two procedures: (1) language choices and alternations as indicators of contextual shifts (changes affecting both the communicative event and the discursive activity) and (2) instances in which explicit focus on language uses are interactionally significant. 


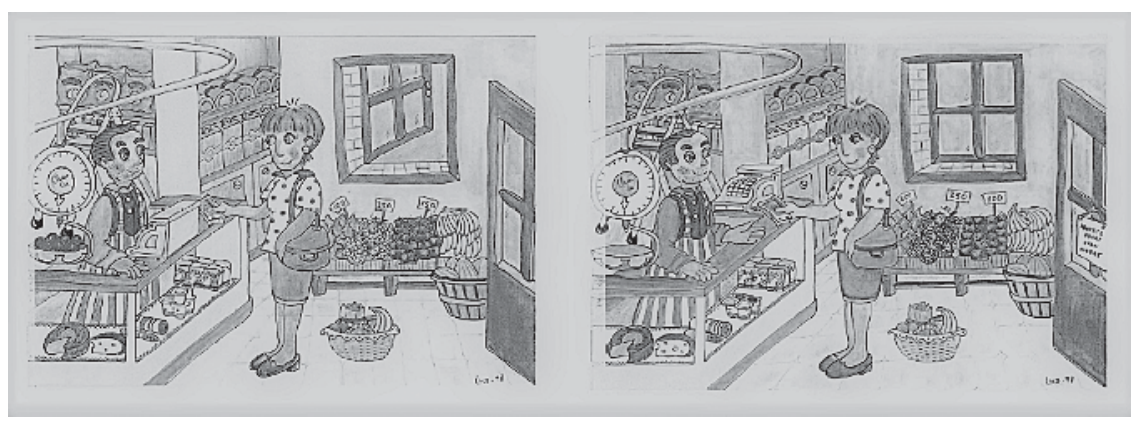

Figure 7.I Materials for the task of spotting the differences between two pictures

In excerpt 1 Raül and Haffi are in the English class carrying out a task of spotting the differences between two pictures (see Figure 7.1). In the first ten lines, both of them are engaged in this task and they focus on the pictures each of them has. Then Jonny interrupts and talks to Raul. In line 18 Haffi refocuses the conversation and he and Raül proceed with the pedagogical task at hand.

Excerpt 1. Participants: Raul, (RAU); Haffi (HAF); the researcher Cecilia (CEC); Jonny (JON)

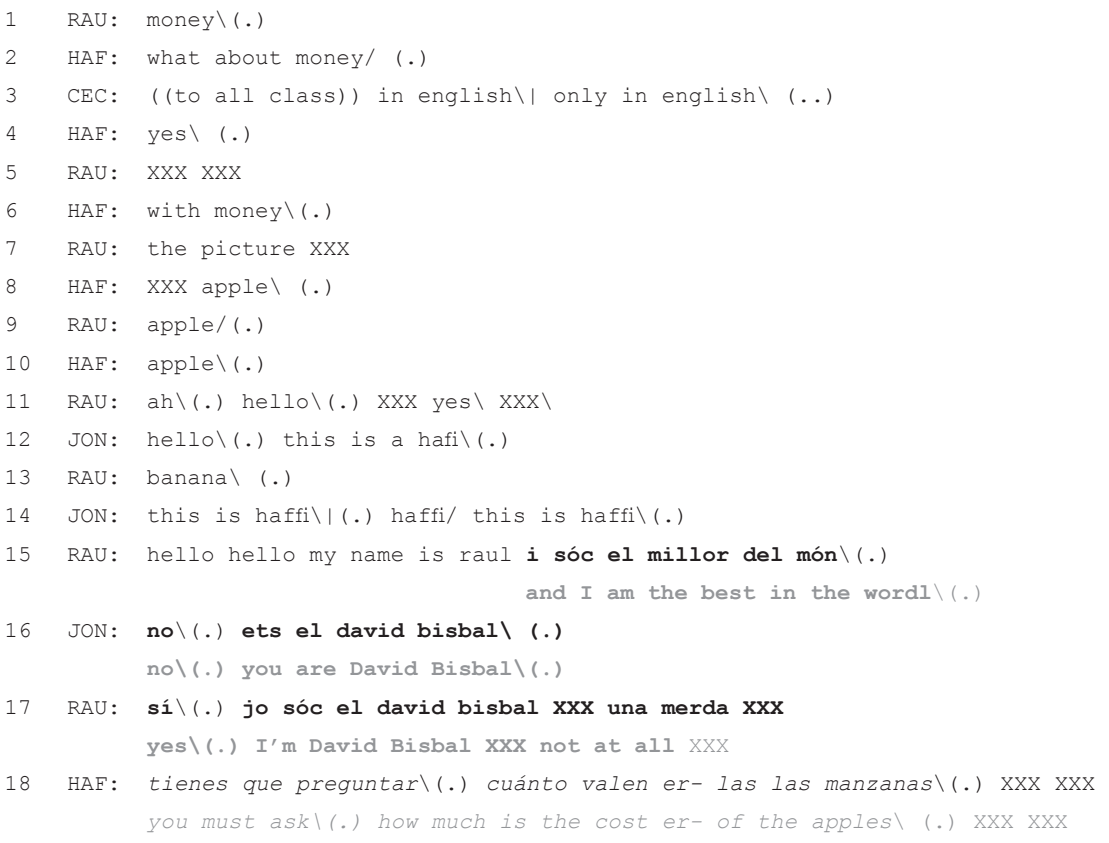




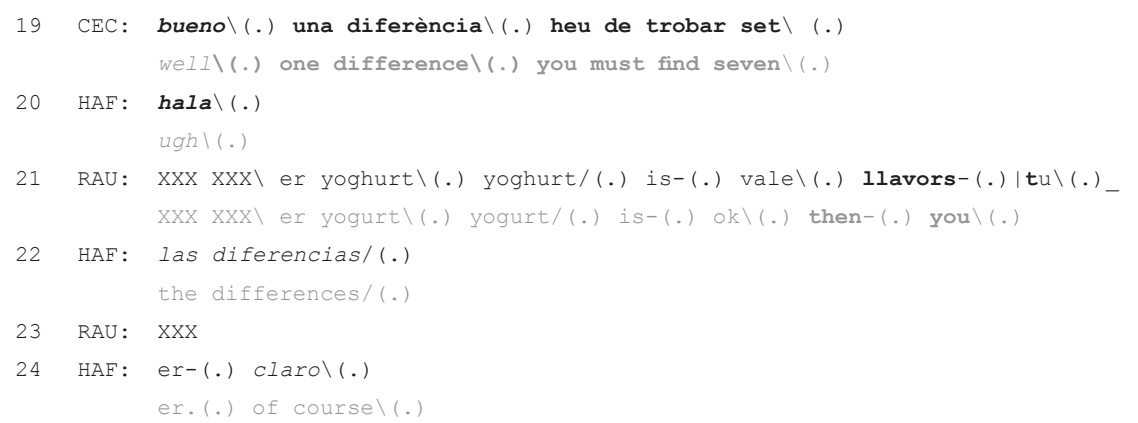

As Haffi and Raül are on task, Jony drops by and Raül greets him in English (line 11). When Jony greets back (line 12), he playfully pretends to introduce Haffi to someone 'present' (e.g. the recording device), as if he were in an interview. Raül ignores the joke and proceeds with the task (line 13), but Jony insists and repeats "this is Haffi" a couple of times (line 14). At this point, Raül gives in, and in reply, he introduces himself to the recording device (line 15). Raül is then orienting himself to the change of event proposed by Jony and to the fact that Jony uses English to play this game.Yet, Raül immediately chooses Catalan (line 15: "sóc el millor del món" / I'm the best in the world) to proceed with the fictional event proposed by Jony. Jony aligns himself with this language choice and, in front of the recorder, he pretends to be at a radio station and suggests Raül to adopt the impersonation of David Bisbal, a popular singer at the time (line 16). First Raül seems to accept the proposal ("sí" /yes) but he turns it down immediately (line 17). In the next turn Haffi intervenes to get Raül's attention back on the task (line 18). He does so in Spanish and tells Rauil what he could ask. Then Cecilia, the researcher, intervenes in Catalan (line 19) to remind the learners which the objective of the task at hand is (finding seven differences between their pictures). Haffi complains (line 20), but Raül proceeds with the task orienting himself to the language of instruction (line 21). His turn, though, contains fillers ("vale"; "llavors") creating fluency in Spanish and in Catalan. This contrast between the use of English and the other two languages is significant in the sense that it contextualises the discursive activities of 'doing the task' and its management (Masats, 1999).

In short, excerpt 1 is interesting because participants use language alternation as a resource to create different contexts, as we have outlined. It is worthy to notice that learners do not associate the use of a given language to a particular activity; instead, they display fluid plurilingual practices. This can also be observed when Cecilia uses Catalan to remind the two learners that they should conduct the task in English as she had previously instructed (line 3). Similarly, Haffi addresses Raül in Spanish to draw his attention back to the task (line 18) at a moment in which Raül was playing a game with Jony, first in English and then in Catalan. Taking the excerpt as a whole, we could argue that for participants the three languages constitute a 'medium of interaction' (Bonacina and Gafaranga, 2011). 
Joc de rol. Representa la següent situació. Un noi va a una parada del mercat a comprar roba.

Role-play. Act out the following situation: a boy visits a stall in a street market to buy clothes.

\section{Client}

customer

1. Saludar

Greet.

2. Dir que vols comprar un jersei.

Say you want a jumper.

5. Respondre la pregunta del venedor.

Answer the question posed by the shop assistant.

7. Contestar. Dir que també vols un altre jersei igual però de color verd. Reply. Say you want another jumper like that but in green.

9. Demanar uns mitjons i demanar per pagar. Ask for a pair of socks.

11. Pagar. Pay.

13. Acomiadar-se. Say good-bye.

\section{Venedora}

Shop assistant

2. Respondre a la salutació. Greet back.

4. Preguntar quin tipus de jersei vol.

Ask what kind of jumper s/he wants

6. Demanar quin color vol. Ask for the colour s/ he wants.

8. Dir que no tens el mateix jersei de color verd.

Say you do not have the same jumper in green.

10. Dir el preu total. Say the total price.

12. Cobrar. Charge for the purchase.

14. Acomiadar-se. Say good-bye.

Figure 7.2 Instructions for the role-play

Excerpt 2 below illustrates a similar phenomenon. In this case, Raül and Haffi are in the Catalan class preparing the dialogue of a role play. The instructions of the task present a sketch of what the dialogue should be like (see Figure 7.2), in the sense that it tells learners the type of information they should provide in each turn of the fictional interaction.

Excerpt 2. Participants: Raul, (RAU); Haffi (HAF); the researcher Cecilia (CEC)

1 RAU: vengal(.) saludal(.) SALUDA (.) saluda XXX

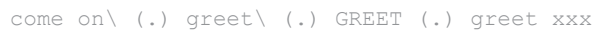

4 HAF: eh mm- vull comprar un jersei $($.

I want to buy a jumper 
RAU: eh-(.) quin tipus de jersei vol/(.)

eh- (.) what kind of jumper do you want/ (.)

HAF : mm-(..) em vull jersei- (.) de color-(.)

mm- (...) I want jumper- (.) coloured-(.)

RAU: de cuir\(.) d'aquests que porten $\mathrm{xxX}$

of leatherl (.) one of those that have Xxx

HAF: sí- això (.) i amb_ de color-(.) vermell\(.)

yes- that $\backslash($.$) and with colour- (.) red \backslash$ (.)

RAU: nol(.) eso pregúntame (.) de_ de quin color vol/(.)

no $\backslash($.) that's it ask me $\backslash($.) what what colour do you want/(.)

HAF: ah-(.) vull un e- de color vermell i-(.) igual al de color verd $\backslash\}($.

ah-(.) I want one e- red and-(.) the same as the one in green $\backslash\}$ (.)

i uns mitjons $\backslash(\ldots)$

and a pair of socks\(..)

RAU: cuánto paga/(.) cuánto vale/(.)

how much do you pay/(.) how much does it cost/(.)

HAF : quant val/(.)

how much does it cost/(.)

RAU: eh-(.) ara li dic\(.)((doing the sound of a calculator)) tic tic tic $\backslash($. eh-(.) I'll tell you immediately \(.) click-click-clack-click-click

tic tic tic $\backslash($.$) eh-(.) són-(.) vuit euros amb noranta cinc cèntims \backslash(.$. clack-clack-clack $\backslash$ (.) eh-(.) it's-(.) eight euros ninety-five cents $\backslash$ (..) què/ ah-(.) que no tinc el mateix-(.) jersei de color verd\(.) that/ ah- (.) I don't have the same- (.) jumper as the one in green $\backslash$ (.) HAF: ah\(.) doncs quan són els_el jersei vermell i els mitjons/ quant són/(.) ah\(.) how much do these_the red jumper and the socks/ How much/ (.) RAU: eh-(.)tic tic tic $\backslash($.$) ((sound of a calculator)) vuit amb noranta cinc \backslash$ (.) eh- (.)click click click $\backslash($.$) \quad eight ninety-five ($ (.)

$\mathrm{HAF}: \quad \operatorname{val} \backslash($.

$\mathrm{ok} \backslash($.

RAU: eh-(.) moltes gràcies $\backslash($.

eh_(.) thank you very much $\backslash$ (.)

HAF: el canvi-(.) adéul(.) [moltes gràcies]

the change-(.) good-bye $\backslash($.$) [thank you very much]$

RAU: [adéu que li] vagi bé \(.)

[good-bye have] a good time \(.)

((to CEC)) ja està ya está (.) ja podem començar a fer teatrel eh/(.) finished finished $\backslash$ (.) we can start performing $\backslash$ eh/ (.)

$\mathrm{CEC}$ : a veure\(.) a veure\(.) ensenya'm-ho a mi $\backslash($.

let's see\(.) let's see\(.) show it to me $\backslash$ (.)

RAU: no lo hemos escrito- eh/(.)

we haven't written it down- eh/(.)

CEC: hafi: : :/(.)

RAU: ((imitanting Cec)) haffi (.) haffi (.)

$\mathrm{HAF}:$ qué: : (..)

what: : (..) 
In lines 1 and 2 children negotiate their roles in Spanish, then the roleplay unfolds in Catalan (lines 3-8) until Raül encounters a problem in the script they are creating and switches into Spanish (line 9) to signal it, but then switches back to Catalan to ask Raül to formulate the question they have in the instructions. This change of discursive activity (from the role play to the pedagogical task) is also indexed by the language switch. Code-switching is employed by Raül in lines 9 and 12 to tell Haffi what he is supposed to say in the fictional dialogue in Catalan. What is interesting to observe is that, even though the instructions that sketch the structure of the role play are written in Catalan, Raül addresses his partner in Spanish to instruct him on what to say. Haffi does what Raül suggests (lines 10-11 and 13), but chooses doing it so in Catalan because they are back 'on task'. When they feel they have their script ready, Raül calls Cecilia to let her know (line 23). At this point, he addresses her in Catalan. She also uses Catalan to ask them to show her their written script (line 24) and, in reply, Raül lets her know, now in Spanish, that they only practiced the dialogue orally (line 25). Raül also uses Spanish to call Haffi (line 29-30), who had left the task for a moment.

This excerpt is interesting because participants conduct a variety of discursive activities that, as a whole, can be envisaged as part of a discursive event we could refer to as 'pedagogical task'. However, these activities are diverse in nature and participants seem to resort to language alternation procedures to distinguish one from another. Thus, the two boys manage their verbal resources and put them at play rather fluidly, what makes it difficult to make a correspondence between language and large sociolinguistic environment. That is, resources are not employed in a diglossic distribution, in which each language should have a function.

\section{Conclusions}

In this chapter we discussed the links between language, interactional context construction and sociolinguistic environments from the perspective of sequential analysis. We focused on learners' language choices and on language alternation as contextualisation cues. Such cues can easily be traced by analysts and indicate that learners' language use does not necessarily align to the oral/ written task instructions nor to the large sociolinguistic policies on language uses. Learners go beyond the explicit regulation on the uses of languages in school tasks and resort to the available resources in their repertoires (Catalan, Spanish and English) to switch between contexts at different levels; to signal a distinction between communicative events and discursive activities (Masats, 
2008). As we have demonstrated, this can be interpreted as an indicator of the modes in which participants signify the relationship between languages and social environment. In our data, contexts are not created in a monolingual mode. Changes in the 'modes' of language use and fluid interpretations of the regulations on use of languages can be interpreted as procedures learners employ to construct a highly plurilingual sociolinguistic environment.

\section{Acknowledgements}

I want to thank all the teachers and children from the school in which I conducted the study I present here for opening their doors to me. Still today, the data I collected comes to my mind on every occasion someone asks for my opinion on the claims that linguistic policies in Catalonia 'force' children to learn Catalan or when someone argues that children of immigrant origin 'prefer' Spanish to Catalan. I immediately recall the memories I collected at the school, thanks to the children and their teachers. And then I think of how much they learnt, and of what I learnt during the 20 years I lived in Barcelona. I think of how we all grew to live in a plurilingual world, managed to show others who we really are, what we do, and what we want to become and, especially, I think of how we could experience that all the languages we know are always there at our service.

\section{References}

Auer, P. (1984). Bilingual conversation. Amsterdam: Benjamins.

Bonacina, F., \& Gafaranga, J. (2011). 'Medium of instruction' versus 'medium of classroom interaction': Language choice in a French complementary school classroom in Scotland. The International Journal of Bilingual Education and Bilingualism, 14(3), 319-334.

Gafaranga J. (2000). Medium repair vs. other-language repair: Telling the medium of a bilingual conversation. International Journal of Bilingualism, 4(3), 327-350.

Gumperz, J. (1982). Discourse strategies. Cambridge: Cambridge University Press.

Gumperz, J. (1999). On interactional sociolinguistic method. In S. Sarangi and C. Roberts (Eds.), Talk, work and institutional order (pp. 453-471). Berlin: Mouton.

Kunitz S., \& Markee N. (2016). Understanding the fuzzy borders of context in conversation analysis and ethnography. In S. Wortham, D. Kim, \& S. May (Eds.), Discourse and education. Encyclopedia of language and education (pp. 15-27). Berlin: Springer.

Lave, J., \& Wenger, E. (1991). Situated learning: Legitimate peripherical participation. New York: Cambridge University Press.

Lüdi, G., \& Py, B. (1986 [2002]). Ettre bilingue. Bern: Peter Lang.

Lüdi, G., \& Py, B. (2009). To be or not to be... a plurilingual speaker. International Journal of Multilingualism, 6(2), 154-167.

Markee, N. (2005). The organization of off-task talk in second language classrooms. In K. Richards \& P. Seedhouse (Eds.), Applying conversation analysis (pp. 197-213). Berlin: Springer. 
Masats, D. (1999). La reparació en el discurs dels aprenents de llengua estrangera. (Unpublished MA dissertation). Universitat Autònoma de Barcelona, Bellaterra.

Masats, D. (2008). El discurs dels aprenents d'anglès com a llengua estrangera: Una aproximació interactivista al procés de construcció de tasques comunicatives. (Unpublished $\mathrm{PhD}$ thesis). Universitat Autònoma de Barcelona, Bellaterra.

Masats, D., Nussbaum, L., Tusón, A., \& Unamuno, V. (2000). Entre simetría complementariedad: La coenunciación en el discurso de aprendices de lenguas. In M. D. Muñoz Núñez, A. I. Rodríguez-Piñero Alcalá, G. Fernández Smith, \& V. Benítez Soto (Eds.), IV Congreso de Lingüística General. Vol. IV (pp. 1763-1774). Cádiz: Servicio de Publicaciones Universidad de Cádiz.

Masats, D., Nussbaum, L., \& Unamuno, V. (2007). When the activity shapes the repertoire of second language learners. In L. Roberts, A. Gürel, S. Tatar, \& L. Marti (Eds.), EUROSLA Yearbook: Vol. 7 (p.121-147). Amsterdam: John Benjamins Publishing Company.

Masats, D., \& Unamuno,V. (2001). Constructing social identities and discourse through repair activities. In S. H. Foster-Cohen \& A. Nizegorodcew (Eds.), Eurosla Yearbook: Vol. I. (p.239-254). Amsterdam: John Benjamins Publishing Company.

Nussbaum, L., \& Unamuno, V. (2000). Fluidité et complexité dans la construction du discours entre apprenants de langues étrangères. Acquisition et Interaction en Langue Étrangère, AILE, 12, 1-18.

Nussbaum, L., \& Unamuno,V. (Eds.). (2006). Usos i competències multilingües entre escolars d'origen immigrant. Bellaterra: Servei de Publicacions de la Universitat Autònoma de Barcelona.

Rampton, B. (2017). Interactional sociolinguistics. Working papers in urban language $\mathcal{E}$ literacies, 205, 2-16.

Seedhouse, P. (2004). The interactional architecture of the language classroom: A conversation analysis perspective. Malden, MA: Blackwell.

Unamuno, V. (2008). Multilingual switch in peer classroom interaction. Linguistics and Education, 19(1), 1-19.

Unamuno,V. (2011). Entre iguales: notas sobre la socialización lingüística del alumnado inmigrado en Barcelona. Sociolinguistic Studies, 5(2), 321-346.

Unamuno, V., \& Nussbaum, L. (2005). Competències orals multilingües d'alumnat estranger a Catalunya. Immersió Lingüística, 7, 115-122. 


\title{
Doing 'being sociolinguists' \\ Students' envisagement of languages, varieties and uses
}

\author{
Dolors Masats
}

\section{Introduction}

Migration movements to and from Catalonia have been common along various historical periods. In 2000 foreign-born citizens constituted 2.8\% of the total population in Catalonia; the figure rose to $15.95 \%$ in 2010 and decreased to $15.11 \%$ in 2019 (Idescat, 2020). Such diasporas have had a great impact in shaping the linguistic and cultural composition of Catalan schools and society. Language education, therefore, must establish links between learners' actual language experiences and language learning. Giving the floor to learners and letting them do 'being sociolinguists', that is, allowing learners to verbalise how they categorise languages, varieties and their users, seems to be necessary to understand their linguistic practices and to establish the aforementioned link to how languages are used and learnt at home and at schools.

People's linguistic and cultural competence is socially-situated, rooted in action and constantly reconfigured. In this chapter we will observe samples of talk-in-interaction in episodes in which Catalan-born primary students of Moroccan ancestry engage in discursive activities of categorising and attributing values to the languages they know. In turn, this will allow us to understand how they envisage otherness in the linguistic practices they engage with their mothers at home or with their peers at school. First, we will theoretically ground the notion of sociolinguistic competence and category building. Next, we will provide methodological information about our study. Then, we will analyse how two groups of learners from different schools engage in the task of describing their plurilingual repertoire and practices. Our analysis will allow us to draw some conclusions with regards to plurilingual education in multilingual settings.

\section{Action-situated competence}

In multilingual schools and societies, people face the need to take part in communicative events in more than two languages, which enable them to develop their 'plurilingual and pluricultural competence' (Coste, Moore and Zarate, 
1997). In this sense, Catalan language policies (see Departament d'Ensenyament, 2018), following European recommendations in language education (see Council of Europe, 2001, 2018), have taken the challenge to envisage schools as learning spaces which must take advantage of the linguistic and culture diversity of their community members (teachers, students, families, etc.). To fulfil such a purpose, classroom practices are expected to enable learners to 'awaken to languages' (Candelier, 2003) and take part in learning tasks that include some sort of access to languages the school does not intend to teach, and which may or may not be the heritage languages of some students in the group. This is particularly important to acknowledge the plurilingual repertoire of all learners and prepare them to participate in many and diverse 'communities of practice' (Lave and Wenger, 1991; Wenger, 1998) along their lives.

Thanks to their participation in various communities of practice, plurilingual speakers become social actors who have varying degrees of proficiency in several languages, constructed through the development of "a range of general competences, usually in close conjunction with pragmatic and sociolinguistic competences" (Council of Europe, 2018:53). The Common European Framework of Reference (CEFR) for Languages (Council of Europe, 2001) associates general competences with the acquisition of trans- and interlinguistic and cultural knowledge (savoirs), skills (savoir-faire) and attitudes (savoir etre). According to Candelier et al (2012), these savoirs enrich plurilingual speakers' potential for learning as they allow them to develop metalinguistic awareness, that is, those cognitive capacities that, among others, enable speakers/ learners to perceive patterns in the use of language, compare linguistic features of different languages, display sensitivity to linguistic and cultural similarities/ differences, talk about / explain certain aspects of one's own language and assume one's own (linguistic / cultural) identity with confidence/ pride while respecting other identities. The CEFR also establishes that sociolinguistic competence is concerned with the social dimension of language use and with the development of knowledge and skills required to socialise and to recognise, understand, appreciate and/or make use of linguistic markers of social relations, politeness conventions, register differences, and dialect and accent features. Similarly, Nussbaum and Unamuno (2006) describe learners' sociolinguistic competence as the ability to recognise language varieties and use linguistic forms adequately to each communicative situation they participate in.

The social construction of the self and of the other is also closely linked to the development of plurilingual and pluricultural competence. Norton (1997: 420) argues that "social identity refers to the relationship between the individual and the larger social world, as mediated through institutions such as families, schools, workplaces, social services, and law courts". Hence, identity building includes 'affiliations' (Coulon, 1993) of one kind or another. Additionally, people categorise each other in social interaction (Fitzgerald, 2015). The study of how categories are built and constantly reconfigured through talk-in-interaction is 
particularly interesting to understand how children in our study enact their sociolinguistic knowledge of and about the languages in their repertoires. In his work on Membership Categorisation Analysis (MCA), Sacks (1992) postulated that categorisations are resources for meaning-making and rely on social categories (e.g. mother, interviewer, correct, deviant) that provide inferences concerning typical associated activities, knowledge or behaviours. Categorising often entails recognising two parties (e.g. adult/child; teacher/student) that lie at the ends of two opposite poles and who, depending on their respective membership, adopt different discursive roles (e.g. expert/non-expert, inquirer/ respondent, information seeker/information user) at different moments in talk-in-interaction. Identifying the categories participants orient to in the process of performing a social action provides information regarding to the values they attribute both to the relationship between language and identity, and to the languages in their own repertoires or in the repertoires of others (Llompart, 2016), as we will see in this chapter. Additionally, it informs on their envisagement of otherness and on how they built their social and cultural bonds. Such information is necessary to embrace diversity in the classrooms. Our chapter expects to be a contribution in this field.

\section{Catalan schools as plurilingual and pluricultural educational milieus}

Data for this study was collected in two distinct periods by the researcher who signs this chapter. In 2001 she visited, once a week for a whole academic year, a school in the city of Barcelona which hosted more than $90 \%$ (first and second generations) of students of immigrant origin. She carried out fieldwork as a teacher assistant of a Year 6 teacher in the areas of mathematics, Spanish and Catalan. As part of the deal with the school board, the researcher also took the role of a school lunch assistant. The data from this school (school 1) presented here was gathered during recess time for lunch. Children were curious regarding the role of the researcher as she was present in their classroom, in the canteen and in the playground. Here we examine part of an informal exchange (excerpt 1) in which a group of three Catalan-born children of Moroccan ancestry spontaneously start singing a popular pop song, imitating how their mothers speak Spanish. Then the conversation revolves around this language variety, which they coin as "Hispamarroc" (Moroccan-Spanish), and their language practices at home and at school. The researcher, a school lunch assistant and other children also take part in the discussion. Our analysis focuses on how children co-construct their representations and categorisations of the variety of Spanish used by their mothers.

Seven years later, the researcher worked for a period of three years with the board of a school (school 2) sited in a village about $60 \mathrm{~km}$ inland from the city of Barcelona in the development of a Comenius initiative on language 
education and video production (see Masats, Dooly and Costa, 2009). Her task often implied assisting Year 6 teachers. In the excerpt we analyse here (excerpt 2) she is in charge of developing a project whose final outcome is a video documentary to report and illustrate language diversity in the village. At the time, the school hosted $2 \%$ of students of immigrant origin. In the class we examine here there were three Catalan-born children from Moroccan families, one girl born in Ghana and 20 other Catalan-born children from Catalan or Spanish ancestry. It is important to note that the families of the children in excerpt 2 come from Nador, a town in the Riff region in northern Morocco, and speak Riffian Berber (a variety of Amazigh). Darija (Moroccan Arabic) in this area is not widely spoken. Most Moroccan families in the Catalan village where the school is located, as well as in neighbouring towns, also come from Nador and, therefore, they speak Riffian Berber to one another. On different grounds, it is also worth mentioning that since 2000 Moroccan Arabic and Amazigh have gained recognition in Moroccan language policies, which up to that moment, and since the country had gained independence, had promoted the used of Fusha (Modern Standard Arabic) and maintained French in the administration, education and economic domains (Moustaoui, 2020). In 2011 Amazigh gained the status of co-official language in Morocco together with Modern Standard Arabic. Moroccan Arabic is regarded as the national language. In excerpt 2 we find Fatima, her cousin Ahmed and Tarik talking to Mar, the researcher, and a classmate, Joan, about Riffian Berber and Moroccan Arabic and comparing them with Catalan and Spanish. Our analysis will focus on how they categorise these languages.

Oral data in school 1 was audio-taped whereas in school 2 it was videotaped. In both cases they were transcribed and examined sequentially from an emic perspective based on the principles of MCA.

\section{Analysis and discussion}

Plurilingual education should provide learners with opportunities to gain the ability to describe languages and their use. Nussbaum and Unamuno (2006) argue that the development of speakers' sociolinguistic competence is the result of a long learning process only possible thanks to their participation in multiple communicative events through which they access language forms in action, become aware of linguistic variation and acquire communicative expertise (Kasper, 2004; Hall, Cheng and Carlson, 2006). This is clearly observable in excerpt 1, where during an informal and spontaneous interaction during recess time, three children display a great ability in identifying and reconfiguring two varieties of Spanish, theirs and that of their mothers. To do so, they sing a song in accented Spanish, using phonetic traits similar to those in Moroccan Arabic. For sake of brevity, we have not presented the song here (see Llompart, 2013 for an analysis of this song). 
Excerpt 1. Participants: The researcher (MAR) and three students from school 1, namely Hanna (HAN), Ikram (IKR) and Rasha (RAS). Other children and adults are present but they do not intervene at this point

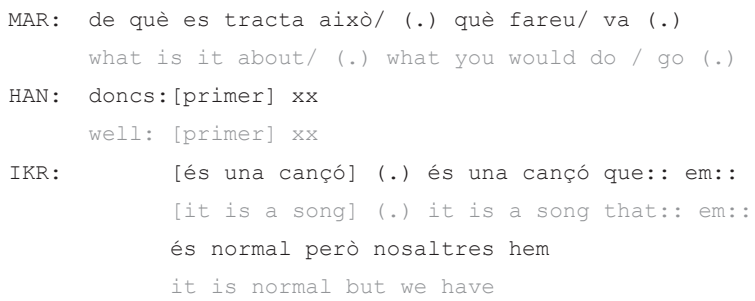




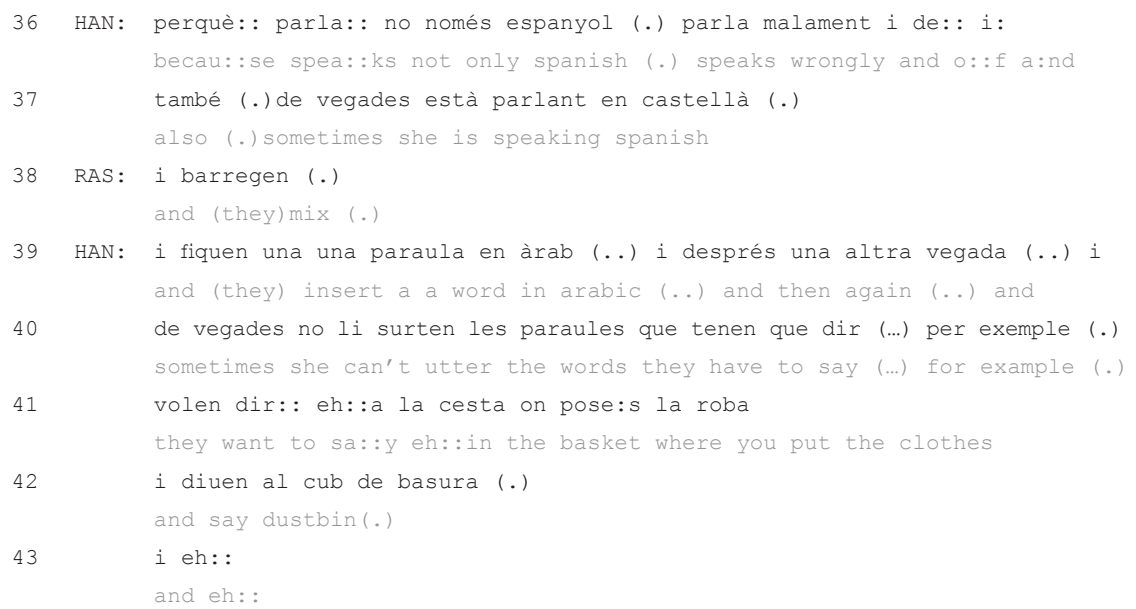

What we can observe in excerpt 1 is that students enact 'being sociolinguists' as they describe how they have identified a language variety and given it a name ("hem tret la llengua que es diu hispamarroc" / "we have made up the language called hispamarroc", lines 12-13). They categorise their use of this variety as "a game" "“és com un joc", line 18) they like to play ("parlem així perquè ens agrada"/ "we talk like that because we enjoy it", line 20) as 'a form of entertainment' ("per divertir-nos una miqueta" / "to have a bit of fun", line 21).Yet, they do not attribute this variety a positive value as they categorise the linguistic practices of their mothers as being "wrong" "les nostres mares parlen malament l'espanyol", lines 10-11; "parla malament", lines 25 and 36). This negative categorisation is co-constructed by two of the learners when they describe that their mothers resort to code-mixing mechanisms ("està parlant en castellà" /"she is speaking spanish", line 37;"i barregen"/“and mix", line 38; "i fiquen una paraula en àrab i després una altra vegada"/"and insert a word in Arabic and then again", line 39) or make mistakes in their lexical choices ("de vegades no li surten les paraules"/ "sometimes she can't utter the words", line 40; "volen dir la cesta on poses la roba i diuen el cub de basura" /"they want to say in the basket where you put the clothes and say dustbin", line 41-42).

Children's discourse in excerpt 1 illustrates a reverse procedure of language transmission in families of immigrant origin. Children here affiliate with their identity of Spanish speakers and categorise themselves as 'expert users' of the language as opposed to their mothers who are envisaged as 'non-experts'. Discussing whether the process of language resocialisation of immigrant women may be complex due to the attitude family members adopt towards their linguistic practices is beyond the scope of this chapter.Yet, our data suggest that if plurilingual education should help children embrace diversity, classroom tasks should enable learners to develop their plurilingual and pluricultural competence to their full potential, that is, not only by guaranteeing the construction 
of knowledge and skills but also the adoption of attitudes that make it possible to categorise as 'positive learning practices' the kind of plurilingual modes of interaction children are describing when they characterise "Hispamarroc", the Spanish language variety of their mothers (see chapter 3 in this volume for an example of such pedagogical practice).

The study of speakers' sociolinguistic competence sheds light on how participants in a communicative event categorise languages and their use. Yet, such categorisations, that are configured through talk-in-interaction, rely on how speakers construct the particular context in which the interaction unfolds, that is, by taking into account what the situation is and who the interactants are. This is clearly observed in excerpt 2, where Ahmed, Fatima, Tarik and Joan are doing group work and exchange information regarding the languages they know.

Excerpt 2. Participants: The researcher (MAR) and four students in school 2, namely Ahmed (AHM), Fatima (FAT), Tarik (TAR) and Joan (JOA)

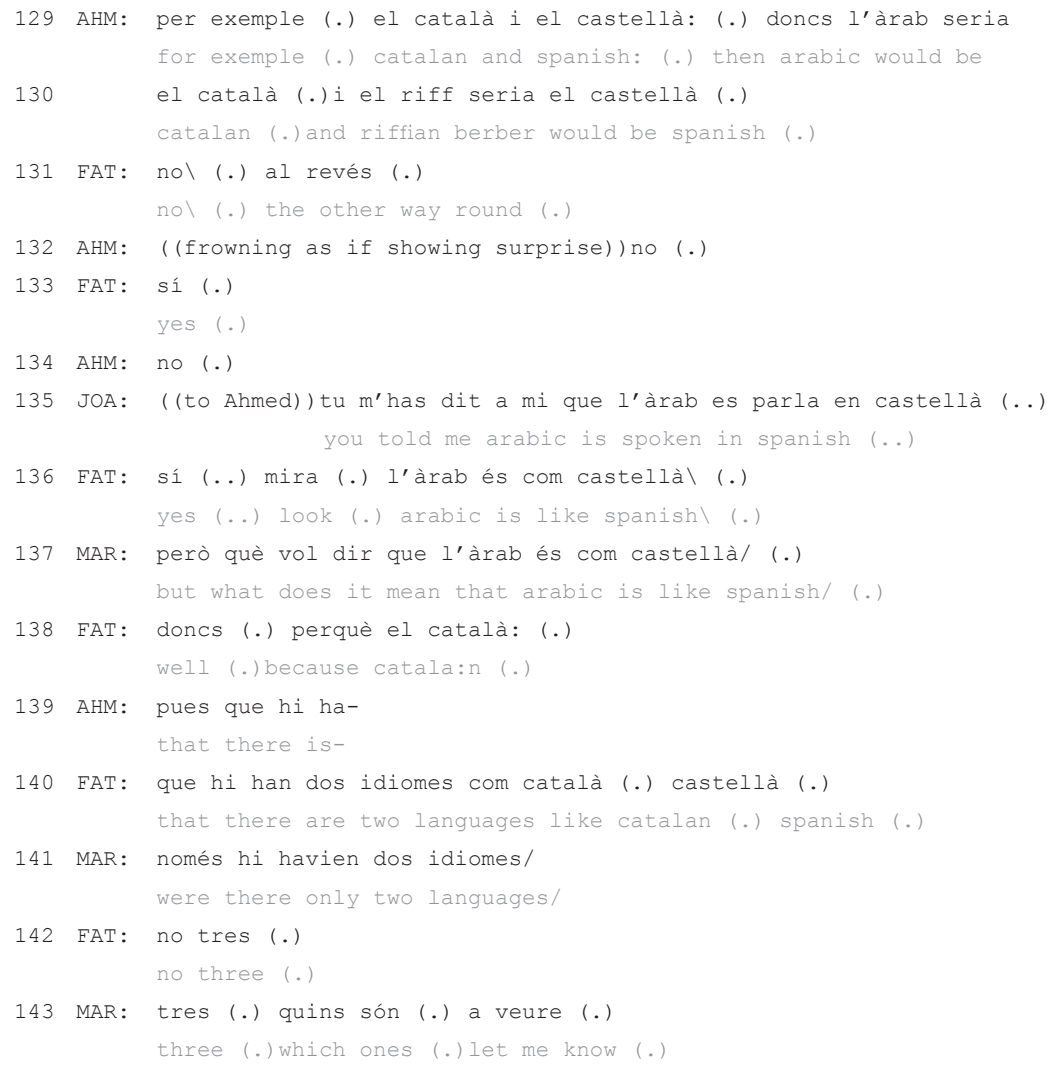




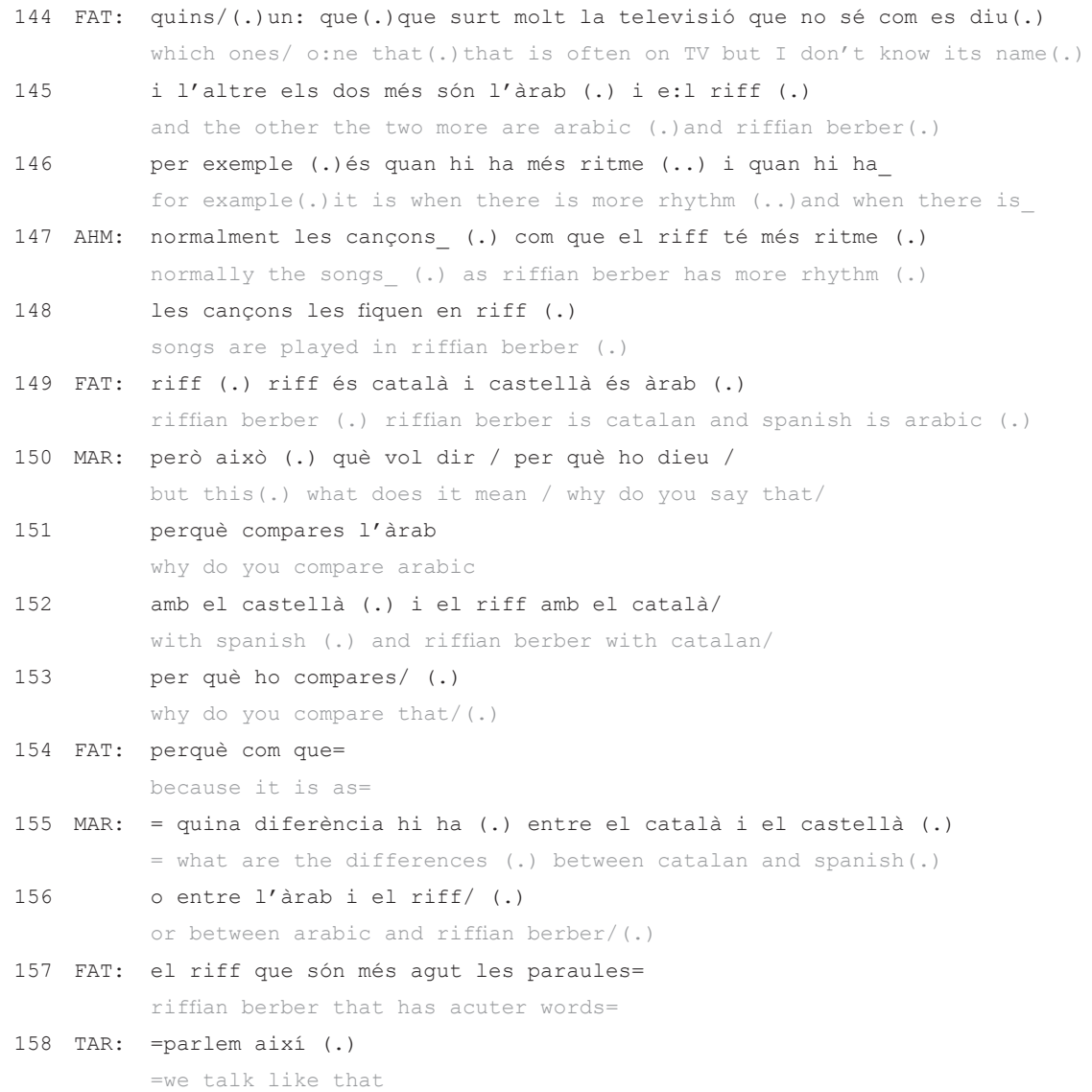

The excerpt starts after Ahmed has informed Joan that Fatima, Tarik and he speak (Moroccan) Arabic and Riffian Berber. Joan then inquiries about these languages and in reply, Ahmed proposes a categorisation in which he compares (Moroccan) Arabic with Catalan and Riffian Berber with Spanish (lines, 129-130). Fatima categorically contradicts him (line 131) by pronouncing the negative adverb in falling intonation followed by the proposition that the 'correct' comparison is the opposite. Ahmed shows surprised, as signalled by frowning and the use of the negative adverb to reject Fatima's proposition (line 132). The two engage in a short competition for the attribution of an 'expert' role on the matter (lines 133-134). After Joan's intervention (line 135) to tell Ahmed he had previously also made the association as proposed by Fatima, the girl self-attributes the 'expert' role and is about to provide and explanation (line 136), when Mar intervenes to ask for a clarification (line 137). Fatima and Ahmed compete again for the 'expert' role and justify the comparison by co-constructing a parallelism between the linguistic situation in Morocco and 
in Catalonia (lines 138-140) and by categorising these territories as spaces in which "there are two languages" ("que hi han dos idiomes com català castellà). Mar displays her identity as a sociolinguist and also adopts an 'expert role' when she questions Fatima's statement by asking the girl if there are only two languages in Morocco (line 141). This triggers the opening of a side sequence in which Fatima, who holds to her self-assigned 'expert role', accepts the correction (she responds there are three, line 142), admits she does not remember the name of the third language, but acknowledges she knows which one it is by providing, again, sociolinguistic information regarding the use of this language ("un que surt molt a la televisió" / "one often on TV", line 144). Her answer confirms Moustaoui's (2020) finding that a vast population of Moroccan Arabic or of Amazigh speakers are unable to speak Modern Standard Arabic as it is not "the mother tongue of the Moroccan people" (p. 534). Fatima, who only travels to Morocco to visit her family, cannot even name it. Yet, the categorisation of Moroccan Arabic as Spanish and Riffian Berber as Catalan that Ahmed and Fatima adhere to repeatedly along this exchange can only be understood as an alignment move that orients to a communal feature or a contextual situation that Joan and Mar can understand and that reveals, although she does not make explicit, the girl has sociolinguistic knowledge regarding the use of these languages: Moroccan Arabic and Spanish are regarded as the national languages of Morocco and Spain respectively; Riffian Berber and Catalan are minority languages even though they hold a status of co-officiality in those territories.

Parallel to this, we cannot ignore that the categorisations the two children construct are made explicit in a context in which they can identify themselves as speakers of Riffian Berber, as Tarik makes explicit in line 158, by using the plural pronoun "we" in "parlem així" ("this is how we talk"). Their identity as Riffians is also apparent when Ahmed and Fatima compare Riffian Berber and Moroccan Arabic by assigning 'positive' traits to the former. For example, Fatima categorises Riffian Berber as a language that "has more rhythm" ("és quan hi ha més ritme", lines 145-146) and Ahmed confirms this categorisation by providing new sociolinguistic information of its context of use ("les cançons es fiquen en riff" / "songs are played in riffian berber", lines 147-148). After this positive description of Riffian Berber, Fatima reaffirms her categorisation of Riffian Berber as "being similar to Catalan" and (Moroccan) Arabic as "being similar to Spanish" ("riff és català i castellà és àrab" line 149), which indexes a positive categorisation of Catalan too, which aligns to the school as an institution and social context in which Catalan is the medium of instruction and communication. When Mar asks Fatima again to clarify the comparison she is constructing (lines 150-153; 155-156), Fatima provides a new category and describes words in Arabic as "being acuter" compared to Riffian Berber ("el riff que són més agut les paraules", line 157). Tarik also accepts this categorisation by affiliating to this language when, as we said, he affirms "this is how we talk" ("parlem així", line 158). This new categorisation reveals that Fatima, apart from possessing sociolinguistic knowledge and competence in (re)constructing 
the context in which languages are used, has also developed the metalinguistic ability of analysing and defining formal aspects of the languages that compose her repertoire. In turn, by sharing this information with Joan and Mar, the children are also contributing to the development of the sociolinguistic competence of their peer and the adult, as they offer them the possibility of gaining socially-constructed knowledge - savoirs - about the target languages.

\section{Conclusions}

Plurilingual and pluricultural education entails actions other than helping learners develop their linguistic repertoire. It also relates to the process of establishing connections between language practices in and outside classrooms to prepare students to participate in multilingual and multicultural societies. Therefore, in classrooms hosting students of different origins and backgrounds, becoming familiar with students' everyday use of languages and understanding how they categorise them is essential for teachers to contribute to the creation of nurturing and inclusive learning environments.

In this chapter we have analysed how two groups of Catalan-born children of Moroccan ancestry do 'being sociolinguists' and spontaneously engage in processes of metalinguistic reflection to provide the researcher and their classmates with sociolinguistic information regarding how they describe and categorise language and their use. Children in our data display great expertise in recognising accent traits or phonetical features of the languages in their repertoire. Yet, such ability does not prevent them from legitimising certain language varieties and disregarding others. For example, in excerpt 1, Hispamarroc, the name the children coin to refer to the Spanish variety spoken by their mothers, is categorised as "speaking wrongly" because it relies on plurilingual modes of communication. This is particularly problematic as plurilingual talk is inherent to the process of language learning. Our results, thus, seem to suggest it is important to 'didacticise' plurilingualism (Llompart et al, 2020) and legitimise plurilingual models of communication in the classrooms as a procedure to scaffold language learning.

We have also discussed how categorisation also relies on how speakers identify themselves and on how they orient to their interactants. In excerpt 2 , children were comparing and categorising the languages in their repertoire and their contexts of use by establishing parallelisms between the social status of Moroccan Arabic and Riffian Berber in Morocco and between Spanish and Catalan in Catalonia. As they identified themselves as Riffians, they also assigned 'positive' categories to this language, and, indirectly to Catalan, the medium of instruction and communication in schools, when they declared that "Riffian Berber was like Catalan" and "Moroccan Arabic was like Spanish".

If we belief that the mission of schools today is to guarantee that students will grow into citizens open to cultural and linguistic diversity and able to communicate and succeed in a multilingual and multicultural society, it is important 
to create the conditions for them to embrace diversity. This task entails taking advantage of learners' plurilingual and pluricultural competence as well as facing the challenges of promoting acceptance towards diversity.

\section{References}

Candelier, M. (Ed.) (2003). Evlang-l'éveil aux langues à l'école primaire-Bilan d'une innovation européenne. Brussels: De Boek-Duculot.

Candelier, M. (Coord.), Camilleri-Grima, A., Castellotti, V., de Pietro, J.F., Lörincz, I., Meißner, F. J., Noguerol, A., \& Schröder-Sura, A. (2012). Le CARAP. Un cadre de référence pour les approches plurielles des langues et des cultures: Compétences et ressources. Strasbourg: Editions du Conseil de l'Europe. Retrieved from www.ecml.at/ Resources/ECMLresources/tabid/277/ID/20/language/en-GB/Default.aspx.

Coste, D., Moore, D., \& Zarate, G. (1997). Competénce plurilingue et pluriculturelle: Vers un cadre europeén commun de référence pour l'enseignement et l'apprentissage des langues vivantes. Strasbourg: Éditions du Conseil de l'Europe.

Coulon, A. (1993). Ethnométhodologie et education. Paris: Presses Universitaires de France.

Council of Europe (2001). Common European framework of reference for languages: Learning, teaching, assessment. Strasbourg: Council of Europe Publishing.

Council of Europe (2018). Common European Framework of Reference for Languages: Learning, teaching, assessment - Companion volume with new descriptors. Strasbourg: Council of Europe Publishing. Retrieved from https://rm.coe.int/cefr-companion-volumewith-new-descriptors-2018/1680787989.

Departament d'Ensenyament (2018). The language model of the Catalan education system: Language learning and use in a multilingual and multicultural educational environment. Barcelona: Generalitat of Catalonia / Ministry of Education. Retrieved from: http://educacio.gencat.cat/web/.content/home/departament/publicacions/ monografies/model-linguistic/model-linguistic-Catalunya-ENG.pdf.

Fitzgerald, R. (2015). Membership categorization analysis. In K. Tracy, C. Ilie, \& T. Sandel (Eds.), The international encyclopaedia of language and social interaction (pp. 98788). New York: John Wiley \& Sons.

Hall, J. K., Cheng, A. and Carlson, M.T. (2006). Reconceptualizing multicompetence as a theory of language knowledge. Applied Linguistics, 27(2), 220-240.

Idescat (2020). Evolució de la població total i estrangera (2000-2019). Barcelona: Institut d'Estadística de Catalunya. Retrieved from: www.idescat.cat/poblacioestrangera/ $? \mathrm{~b}=0$.

Kasper, G. (2004). Participant orientations in German conversation-for-learming. Modern Language Journal, 88(4), 551-567.

Lave, J., \& Wenger, E. (1991). Situated learning. Legitimate peripheral participation. Cambridge: Cambridge University Press.

Llompart, J. (2013). De madres a hijas, de hijas a madres: El cambio en la transmisión intergeneracional de lenguas. Bellaterra Journal of Teaching \& Learning Language \& Literature, 6(3), 47-65.

Llompart, J. (2016). Pràctiques plurilingües d'escolars d'un institut superdivers: De la recerca a l'acció educativa. (Unpublished $\mathrm{PhD}$ thesis). Universitat Autònoma de Barcelona, Bellaterra.

Llompart, J., Masats, D., Moore, E., \& Nussbaum, L. (2020). Mézclalo un poquito. International Journal of Bilingual Education and Bilingualism, 23(1), 98-112. doi: 10.1080/ 13670050.2019.1598934. 
Masats, D., Dooly, M., \& Costa, X. (2009). Exploring the potential of language learning through video making. In L. Gómez Chova, D. Martí Belenguer, \& I. Candel Torres (Eds.), Proceedings of EDULEARN09 Conference (pp. 341-352). Valencia: IATED. Retrieved from: http://mediaeducation.net/images/divis/ DIVIS_Research_Presentation.pdf.

Moustaoui, A. (2020). Language policy and planning in Morocco: A critical approach. In E. Benmamoun \& R. Bassiouney (Eds.), The Routledge handbook of Arabic linguistics (pp. 531-545). London: Routledge.

Norton; B. (1997). Language, identity, and the ownership of English. TESOL Quarterly, 31 (3), 409-429. doi: 10.2307/3587831.

Nussbaum, L., \& Unamuno,V. (2006). La compétence sociolinguistique, pourquoi faire? Bulletin Suisse de Linguistique Appliquée, 84, 47-65.

Sacks, H. (1992). Lectures on conversation. Edited by Gail Jefferson. Cambridge, MA: Blackwell Publishers.

Wenger, E. (1998). Communities of practice: Learning, meaning, and identity. Cambridge: Cambridge University Press. 
Plurilingual and multimodal activities in knowledge construction 


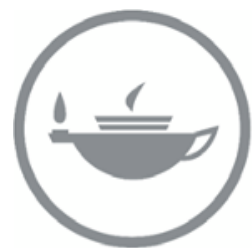

Taylor \& Francis Taylor \& Francis Group http://taylorandfrancis.com 


\title{
Plurilingual teamwork practices in an internationalised setting at a Catalan university
}

\author{
Eulàlia Borràs
}

\section{Introduction}

This chapter explores the interactive practices of a group of students in an English-medium instruction (EMI) setting at a public university in Catalonia. In an increasingly connected and globalised world, the need to communicate and to conduct interactive practices among people who do not share a first language but need to carry out a task jointly is not going to decrease any time soon. Quite the contrary, the data we are presenting here were recorded around 2010 and, re-examining them, we find they are still very much up to date. In fact, the question continues to be the same: In an internationalised setting, what are the practices and resources that are mobilised by participants who communicate in English-as-a-lingua-franca (ELF) to successfully interact and accomplish the task at hand? We think this is a relevant issue for researchers, teachers, and policy makers who seek to promote the learning of both content and language in internationalised settings by implementing internationalisation-athome (Nilsson, 2003) policies.

Our study, embedded in the socio-constructivist theory, draws on conversation analysis to explore the situated social practices of a workgroup that is engaged in co-constructing meaning in the EMI classroom. In a qualitative and emic approach, our data-driven study will describe and analyse the interactive practices of a team comprising three students: a local Catalan student and two Turkish exchange students. Our goal is to identify how these students reach their communicative goals by examining the ways in which they manage their semiotic resources to reach interactional order.

The structure of this chapter is as follows. First, we outline the main approaches that structure this contribution. Then we present the methodology, as well as the class and the participants in the study. Next, we provide the analysis and discussion in three subsections: the first one explores how language negotiations are made in relation to categorisations of expertise; the second one analyses how participants mobilise their plurilingual repertoires while they orient to the task and the third one studies how they present the task in ELF talk. The text concludes with a discussion of our results. 


\section{Theoretical framework}

Starting with Firth and Wagner (2007), there are several studies that have redefined second language acquisition (SLA) research from a conversation analysis perspective (Seedhouse, 2004; Hellerman, 2008, Markee, 2008, Pekarek Doehler 2009). Likewise, extensive research shows that students mobilise plurilingual resources, including code-switching, hybrid forms and multimodality, to manage the organisation of the task and gradually incorporate more resources in the L2 (Nussbaum and Unamuno, 2000; Swain and Lapkin, 2000; Lüdi, 2006; Garcia, 2007; Masats, Nussbaum, and Unamuno, 2007; Duff and Kobayashi, 2010; Moore and Nussbaum, 2011; Borràs et al 2012; Moore, Borràs, and Nussbaum, 2013; Moore, Nussbaum and Borràs, 2013; Nussbaum, Moore and Borràs, 2013). In a similar vein, several studies show that there may be a link between the focalisation in a language problem by L2 students and the development of deeper content in the subject matter or content "density" (Gajo, 2007) in the EMI classroom, thus resulting in knowledge construction (Barwell, 2005).

We are interested in exploring the organisation of social action in everyday interaction (Sacks, 1972, 1992); that is, how students display their orientations to the sequential organisation of classroom interaction and orient to the task (Breen, 1989; Ellis, 2003) in a perspective that is indexical in nature and takes into account the environmentally-coupled gesture (Goodwin 2007; Seedhouse and Almutairi, 2009). It is this micro level of detail that allows us to sequence the action in order to trace the 'what' (what contents the students are tackling) but, most importantly, the 'how'. The how here refers to the organisation of the activity: How students go about negotiating language and how they categorise themselves in terms of expertise according to membership categorisation (Sacks, 1992; Antaki and Widdicombe, 1998). Also, how they distribute the tasks and how they manage these activities in interaction taking into consideration the management of the plurilingual resources available. In sum, we are trying to interrelate (1) how participants interact to carry the task to term, taking on the socio-constructivist approach that interaction is the basis for knowledge construction, and (2) how they organise the mobilisation of plurilingual resources.

To analyse the connection between the situated interactive practices of the participants and how these are affected by the mobilisation of language repertoires, we will draw on the axis between the concepts of progressivity and intersubjectivity. Progressivity (Schegloff, 2007) involves all the efforts deployed by the participants to jointly construct the course of action and move the action forward toward completion. This includes practices by participants in which they 'make normal' or 'let pass' (Firth, 1996) hybrid or invented words by not orienting to them, for example. Conversely, intersubjectivity (Heritage, 2007) refers to all the orientations towards the interactional needs of the participants and may include repairs, and clarification demands. 


\section{Methodology}

The data of the study belong to a set of video-taped classes at a world-class public university. The participants are second-year chemical engineering students learning in teams about the characteristics of leather. The class is being monitored by the EMI instructor, Caterina. The other participants are Fatma, Ahmet, both Turkish exchange students, and Laia, a local female student, bilingual in Catalan and Spanish. In the last excerpt, Selma and Cem, students from another team, briefly participate in the conversation and are therefore included in the transcription. The data were accompanied by field notes and transcribed using ELAN following the Jefferson (2004) conventions in what was an action research study. These excerpts were discussed in data sessions at the Research Centre for Plurilingual Education and Interaction (GREIP) and in the DYLAN project (Nussbaum, Moore and Borràs, 2013).

\section{Analysis and discussion}

Below are five excerpts to illustrate how the students orient to the task, how they go about completing that task and how they present it to their peers.

\section{Orienting to the task: Language (re)-negotiations related to categorisations of expertise}

The students have been asked to complete a worksheet ('task-as-workplan' Breen, 1989) with several discussion questions comparing different methods of tanning, i.e. vegetable versus chromium tanning, and then to present the results orally to the rest of the class. In the following excerpt, while the three students are orienting (Goodwin, 2007) to the worksheet, Laia, the Catalan student, makes relevant her asymmetric competence in English.

Excerpt 1. Participants: One teacher (CAT) and three students, Ahmet (AHM), Fatma (FAT) and Laia (LAI)

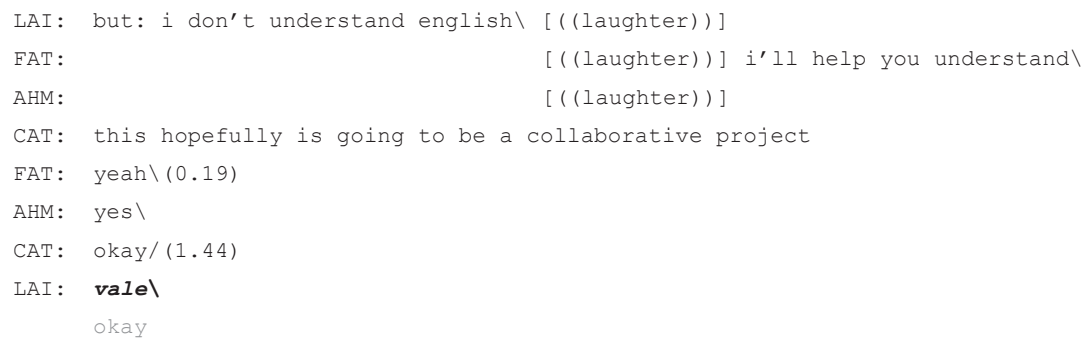

Laia, the local participant, immediately orients to her self-perceived lack of language competence by uttering "but I don't understand English" in line 1. 
She changes the footing by initiating her turn with the appositional beginning "but" as a turn-entry device pre-start (Sacks, Schegloff and Jefferson, 1974) possibly with the aim of negotiating the implicit English-only language policy. Laia's self-categorisation (Sacks, 1972, 1992) as an English non-expert, though, is immediately mitigated by Fatma's offer to help in the next turn. This explicit offer marks Fatma (and Ahmet's) willingness to cooperate and signals the beginning of Fatma's de facto categorisation as a facilitator and expert collaborator throughout the class session. In line 4 Caterina seems to establish a connection between English language use and collaboration, which students seem to align to in lines 5-8. It is relevant that Laia does so in plurilingual mode, using "vale" (line 8) to express agreement as she is de facto already violating the implicit English-only policy.

Excerpt 2. Participants: One teacher (CAT) and three students, Ahmet (AHM), Fatma (FAT) and Laia (LAI)

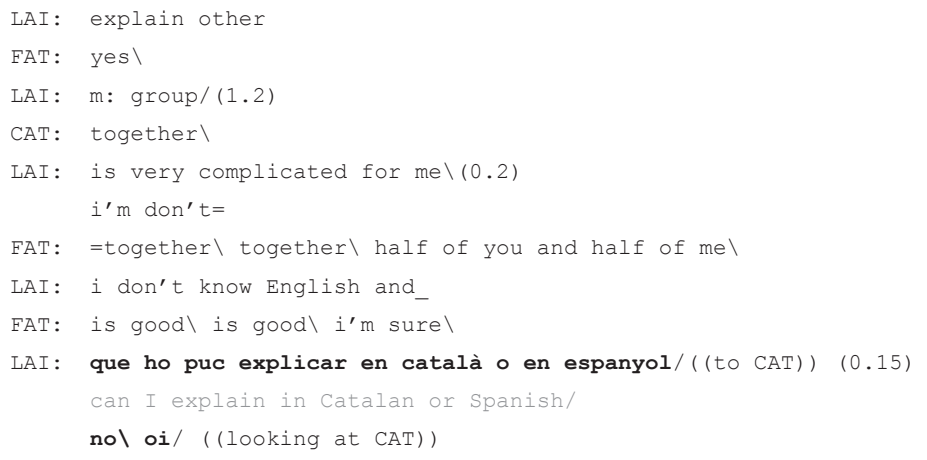

Laia insists in lines 1, 3 and 5 that it is "very complicated" for her to present conclusions to the class and continues categorising herself negatively in line 6. Then Fatma interrupts with an offer to present together. Laia, however, ignores her and makes explicit her self-categorisation as a non-English speaker in line 8, as Fatma responds in the next turn reassuring Laia by stating her English is good. Laia, once again ignoring Fatma's attempt at mitigating negative categorisations, codeswitches to Catalan in a participant-related switch (Auer, 1984) and asks if she can present in Catalan or Spanish instead. Without even giving the teacher any time to respond, in line 11 Laia self replies with a "no\oi/" (no, right?) showing awareness but not alignment to implicit language policy. The very brief silence between turns shows that Laia is aware the tacit policy is that English is the class lingua franca. Again, this excerpt shows how Fatma arises as the expert and facilitator, an identity that emerges from the local and situated action throughout the whole session. 
Orienting to the task: How students mobilise their plurilingual repertories while trying to achieve completion of the task (progressivity)

After the first set of data, in which we explored the initial categorisations of language expertise and language negotiations, we want to show how the group actually manages to accomplish interactional order and progress towards the task given the language policies in place.

In excerpt 3 the participants are discussing the characteristics of leather:

Excerpt 3. Participants: The three students, Ahmet (AHM), Fatma (FAT) and Laia (LAI)
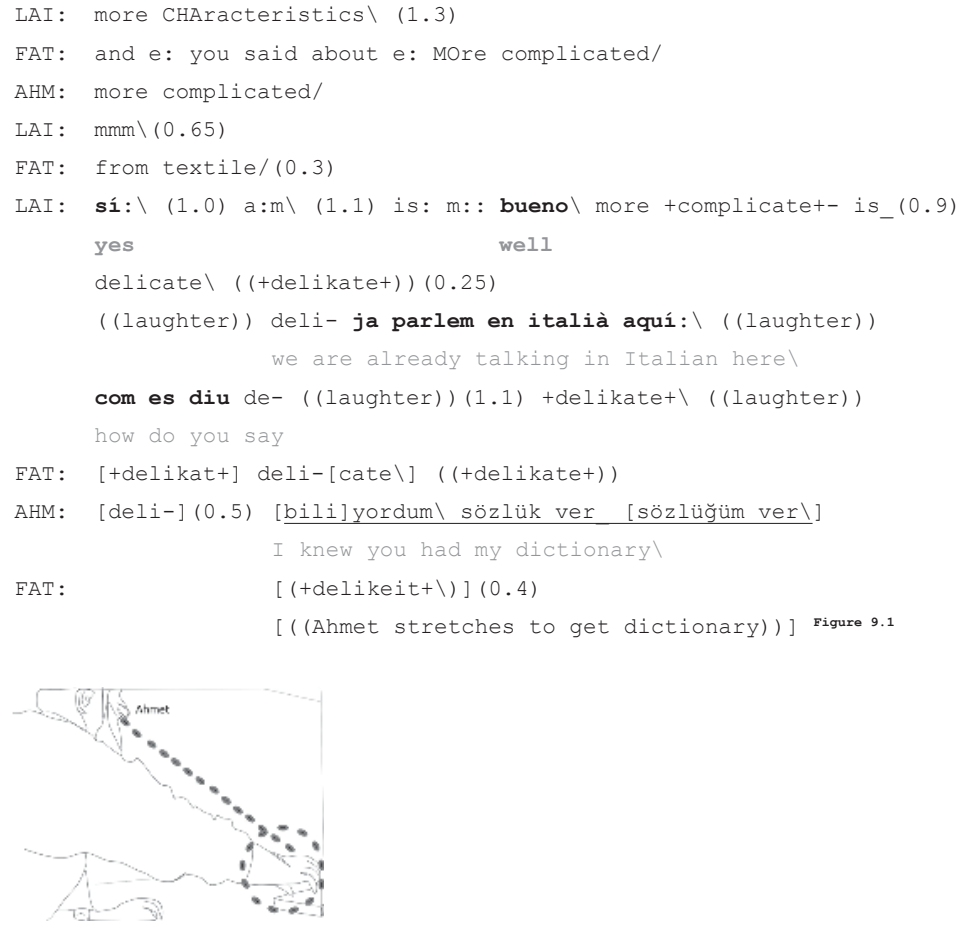

Figure 9.1

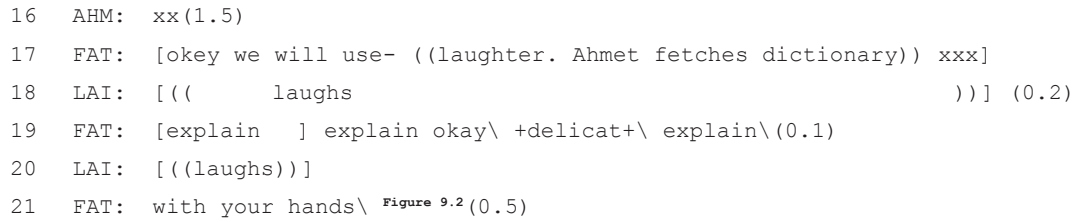




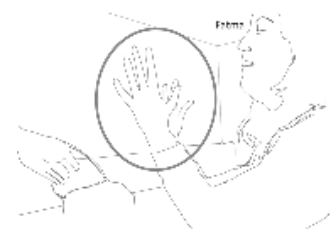

\section{Figure 9.2}

22 is better-Figure 9.3

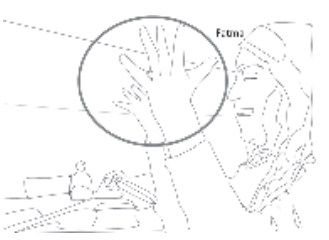

\section{Figure 9.3}

AHM: $x x$ we can use this (.) spanish turkish ((hands Laia dictionary)) (1.1)

LAI: delicadol ((searching dictionary)) (0.5) delicate

25 AHM: delicado $\mathrm{xxx}$ m__(3.5)

26 Figure 9.4 ((Laia searches, Fatma observes))

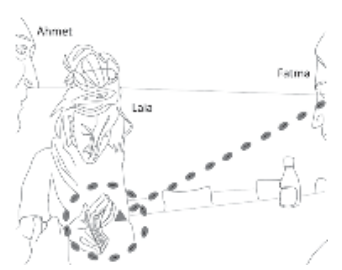

\section{Figure 9.4}
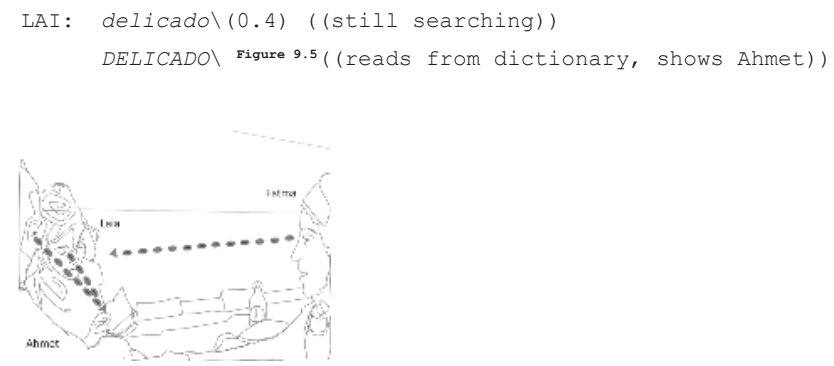

Figure 9.5 

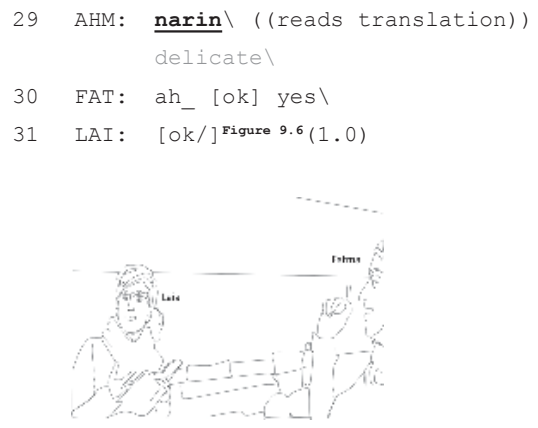

Figure 9.6

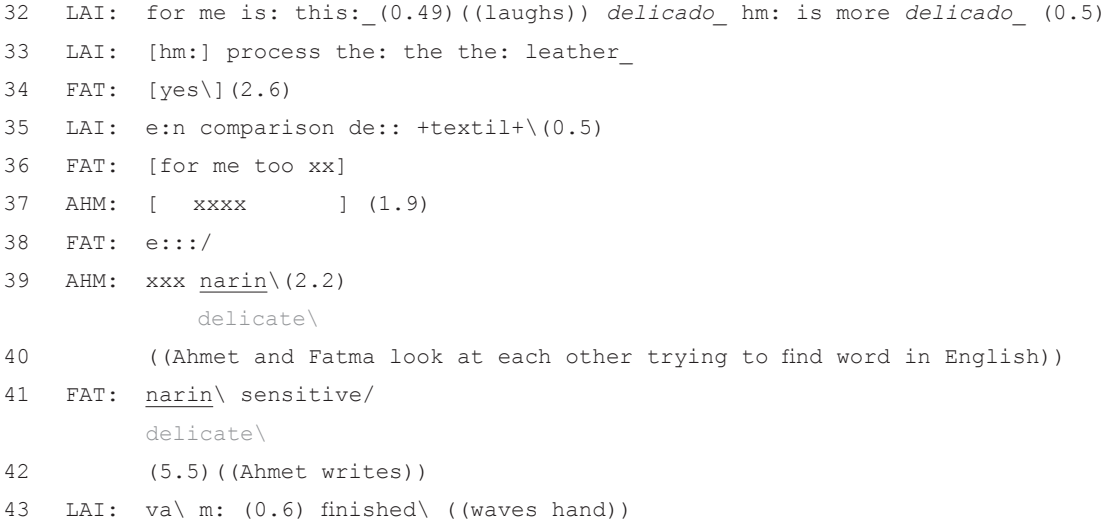

Fatma, once again acting as a mediator, encourages Laia in line 2 to develop an idea she just came up with: that leather technology is "more complicated" than textile technology. Laia specifies that the process is "more delicate". She pronounces this word in a way she attributes to Italian "+ delikate+" and,laughing, declares "ja parlem en italià aquí" possibly to avoid face threat. As the Turkish students seem not to understand the "Italian" pronunciation, Laia codeswitches to Catalan to address the teacher and asks how to say "+delikate+" in English in line 11. Ahmet and Fatma take over and generate alternatives quickly, proactively performing the facilitator role in the momentary absence of the teacher. In this vein, Ahmet stretches his body to fetch the Spanish-Turkish dictionary while he tells Fatma in Turkish, in a participant-related switch, that they ought to consult the dictionary, in lines 13-15. Fatma, as a facilitator, simultaneously encourages Laia to explain "+delikate+" with her hands as it "is better" (lines 21-22). Meanwhile Laia locates the Turkish equivalent and physically orients towards the dictionary with Ahmet, who pronounces "narin" out loud. Ahmet and Fatma in lines 39-41 jointly come up with an equivalent English term, 
“sensitive”, which he writes. In lines 32-35 Laia completes the scientific argument that provided the sequential context for attention to a linguistic aspect of the discipline (Gajo, 2007), a process facilitated by the students' mobilisation of their plurilingual repertoires including hybrid terms like "+delikate+", among other resources such as gesture and the dictionary. Laia utters "va / finished" in line 43, signalling the return to the progress axis (Schegloff, 2007) of the task and the end of the attention to intersubjectivity (Heritage, 2007).

In a similar fashion, in excerpt 4 , the participants deploy all the plurilingual resources at their disposal to reach both interactional order and knowledge construction when discussing the colours obtained through different tannages.

Excerpt 4. Participants: One teacher (CAT) and three students, Ahmet (AHM), Fatma (FAT) and Laia (LAI)
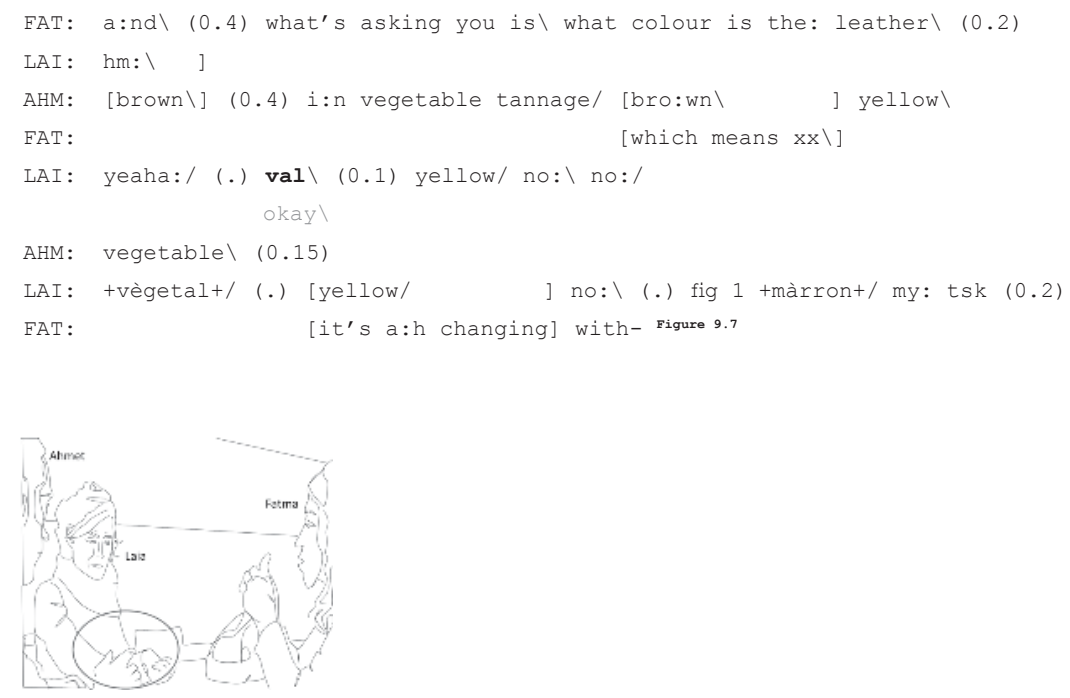

Figure 9.7

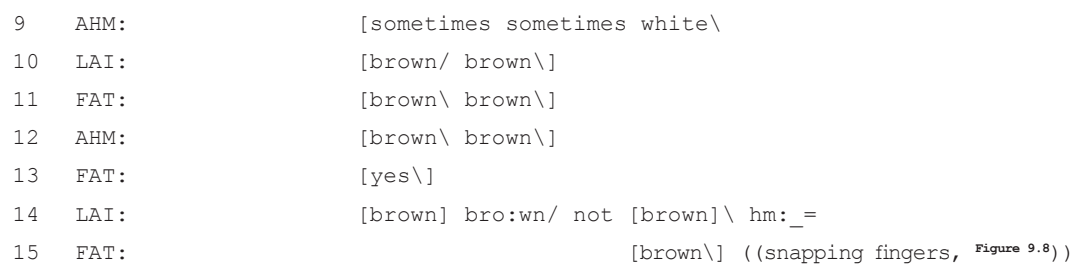




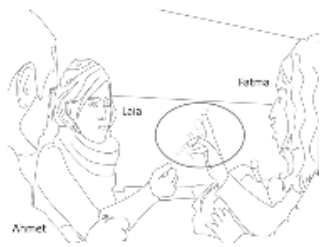

Figure 9.8

16 AHM: =brown $\backslash=$

17 LAI: ( (to prof)) =color cre- color crema/ com és color crema/ o color clar $\backslash$

cream colour/how do you say cream color/ or light color

18 CAT: a: :h\(0.2) on [t'és/]

19 LAI: [it] depends de: extract $\backslash(0.3)$ color [depend de extract $\backslash$ ]

20 FAT: it depends of the exTRACT $\backslash(0.1)$ on the [extract $\backslash$ yes $\backslash$ ]

21 AHM: [exactly $](0.2)$

22 LAI: for example i:f if the extract is +sintetik+ the colour is_(0.6) m:ore

intensive \(0.2) ((to prof)) more/ no\ [more és més intensiul no/]

is more intensive l right/

FAT:

[bu:t for example vegetable $\backslash$ if you

are using mimosa and if you [are u]sing chestnut they are different

colours [but a:l]most brown/

LAI: [(right $\backslash$ ?) ] (2.2) [hm hm\]

AHM: =brown yeah $\backslash=$

FAT: =yeah $\backslash(0.5)$ dark brown $\backslash$ [light brown/]

AHM: $\quad[\operatorname{xxx}(0.4)]$

LAI: a:h okey\s-/ yes yes/ [a:nd__ ]

Ahmet suggests the colour resulting from vegetable tanning is brown but adds yellow as well in line 3. After an apparent consensus in line 5, this is problematised by Laia in lines 5 and 7 as she mobilises the hybrid word +vègetal+, to which none of the other participants orient, in a 'let pass' or 'make normal' (Firth, 1996) stance. Additionally, as Laia seems not to remember how to say "brown", she bricolages the hybrid word "+màrron+" (with a supposed English pronunciation) pointing at her brown sweater, thus drawing on the multimodal resources available to her, as seen in Figure 9.7. After a brief negotiation in which Ahmet suggests white, they all agree the right colour is brown in line 13. However, Fatma seems to be looking for a more rigorous description by snapping her fingers, Figure 9.8, in what seems to be a cognitive marker (Markee, 2000) that could indicate she is searching for more scientific accuracy. In line 17 a language problem arises and Laia codeswitches to Catalan to address the teacher and find out how to say "color crema". Without waiting for a response, on line 19, Laia focuses her attention on the content and addressing the Turkish students in hybrid English elaborates that the tanning 
extract is an important variable in the description of the final colour obtained, "colour depend de extract". The two Turkish participants align with Laia's academic considerations in lines 20-21. Hence, Laia here is starting to construct a reformulation of her identity as a non-expert we had observed in the first two excerpts and is de facto debunking her initial categorisation. Thus, Laia constructs an expansion of content with a quite elaborate scientific explanation of proportionality "if the extract is synthetic the colour is more intensive" in lines 22-23. Interestingly as well, while Laia asks for confirmation of "more" in line 23, Fatma pro-actively expands content from a different angle "but for example vegetable if you are using mimosa if you are using chestnut they are different colours but almost brown" in lines 24-26. Again, the focalisation of a language problem has resulted in an expansion of the scientific content. The interaction goes on until the participants reach consensus that vegetable tanning produces different shades of brown in lines 29-31.

This excerpt shows that the focalisation of attention in linguistic resources that present challenges in the L2, like "color crema", has resulted in more detailed attention to the academic content in a remediation effort (Gajo, 2007). Likewise, we find that students exploit plurilingual resources when they do not find solutions to their communicative problems in the L2. In this case, deploying plurilingual resources contributes to reaching saturation of contents in the subject matter.

\section{Completing the task (Task-as-outcome): Presenting results in ELF talk}

Below is an excerpt of Laia's presentation to the whole class:

Excerpt 5. Participants: One teacher (CAT) and five students, Ahmet (AHM), Cem (CEM), Fatma (FAT), Laia (LAI) and Selma (SEL)

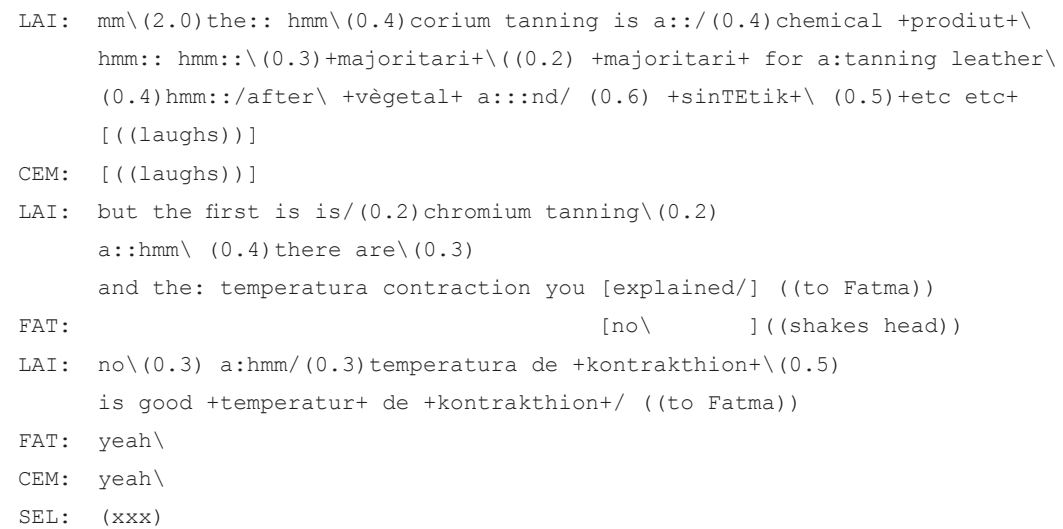


LAI: +temperature kontrakthion+ is more $\backslash(0.4)$ en +comparesont a: (0.2) a: (0.2) +temperatura kontraktion+ de: +végetal+\(0.5) is mo:re(0.3) Figure 9.9

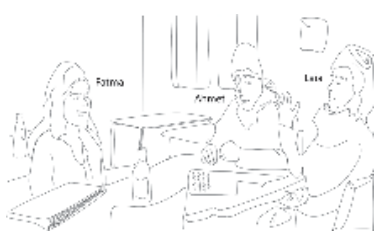

Figure 9.9

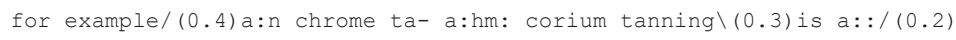

In the final presentation Laia mobilises several linguistic and multimodal resources from her repertoire. From lines 1-3 she uses several cognates with hybrid pronunciations (+produit,++ sintètic,++ majoritari,++ vègetal $+\ldots)$ that help her construct her scientific discourse. Thus, she enumerates types of tanning and goes on to explain chromium tanning. The other participants let pass of Laia's confusion 'corium-chromium' in lines 1 and 7, practicing the 'make it normal' strategy. The participants seem to prefer not to orient to repairing Laia's hybrid forms even when she is asking her group for explicit confirmation, as in line 11 "is good +temperatur+ de +kontrakthion+/", probably because this is a public presentation. Likewise, when Laia shows uncertainty 
with figures, Cem and Fatma help her and scaffold her efforts in lines 26 and 28 among shared laughs to decrease face threat. Laia closes this excerpt by showing alignment with Fatma's confirmation in lines 33-35 and explains in her hybrid English that the colour depends on the percentage of chromium, "depend del tant per cien de:/ chromium \". In spite of her asymmetric competence in the English language, Laia emerges as an active participant in the joint construction of knowledge due to her expertise in the discipline, the mobilisation of her plurilingual repertoire (codeswitching, hybridity, gestuality, among other semiotic resources), as well as the joint repairs, confirmations, and completions displayed by all participants.

\section{Conclusions}

This chapter has analysed the plurilingual interactive practices of a workgroup at a Catalan university in an EMI setting. We have examined how the participants, local and international students, organise sequentially their actions through multimodal and plurilingual resources. The participants, despite the asymmetries in their language competence in L2 (English), manage to successfully orient to the completion of the ongoing activity by deploying a set of tools that include 'let it pass' and 'make it normal' practices, as well as the development of all the semiotic resources at their disposal to achieve interactional order. This interactive organisation, together with the mobilisation of the plurilingual resources available (codeswitching, gestures, artefacts, bricolage...) has shown to facilitate the construction of knowledge in internationalised scenarios (Nussbaum and Unamuno, 2000; Hall, 2004; Lüdi, 2006; Masats et al., 2007; Borràs et al., 2012).

We have also examined how the participants sequentially orient to the task ('task-as-workplan', Breen, 1989) despite initial negative categorisations of L2 expertise. By mobilising their plurilingual repertoires and engaging in situated action the participants manage to carry out the task maintaining a balance between moving forward towards progressivity (Schegloff, 2007), that is to say, completing the task; and intersubjectivity (Heritage, 2007), namely orienting to the needs of fellow participants with attention to repairs and confirmations. In addition, we observe a progressive empowerment of the local participant, initially self-categorised as a non-English speaker. We have also explored how the discussion of a language problem in the small group (task-in-process, Seedhouse, 2004) results in an increase in density in the contents of the subject (Gajo, 2007).

In sum, our analysis of the data suggests that in a specific workgroup composed by local and international students who communicate in ELF in an EMI classroom, plurilingualism is a resource that results in (1) increased participation regardless of initial categorisations of expertise; (2) more ability to reach interactional order; and (3) greater focalisation in scientific content. We would also venture that plurilingualism has brought joy to the situated and local interactive practices of the participants. 


\section{References}

Antaki, C., \& Widdicombe, S. (Eds.) (1998). Identities in talk. London: Sage Publications. Auer, P. (1984). Bilingual conversation. Amsterdam: John Benjamins.

Barwell, R. (2005). Integrating language and content: Issues from the mathematics classroom. Linguistics and Education, 16, 205-218.

Borràs, E., Moore, E., Nussbaum, L., \& Patiño, A. (2012). Emergence de modes plurilingues dans des cours universitaires en L2. In L. Mondada \& L. Nussbaum (Eds.), Interactions cosmopolites: L'Organisation de la participation plurilingue (pp. 63-98). Limoges: Editions Lambert Lucas.

Breen, M. (1989). The evaluation cycle for language learning. In R. K. Johnson (Ed.), The second language curriculum. Cambridge: Cambridge University Press.

Duff, P., \& Kobayashi, M. (2010). The Intersection of social, cognitive, and cultural processes in language learning: A second language socialization approach. In R. Batstone (Ed.), Sociocognitive perspectives on language use and language learning (pp. 7593). Oxford: Oxford University Press.

Ellis, R. (2003). Task-based language learning and teaching. Oxford: Oxford University Press.

Firth,A. (1996). The discursive accomplishment of normality: On 'lingua franca' English and conversation analysis. Journal of Pragmatics, 26, 237-259.

Firth, A., \& Wagner, J. (2007). Second/foreign language learning as a social accomplishment: Elaborations on a reconceptualized SLA. The Modern Language Journal, 91 (Focus Issue), 800-819.

Gajo, L. (2007). Linguistic knowledge and subject knowledge: How does bilingualism contribute to subject development? International Journal of Bilingual Education and Bilingualism, 10(5), 563-581.

García, O. (2007). Foreword: Intervening discourses, representations and conceptualizations of language. In S. Makoni, \& A. Pennycook (Eds.), Disinventing and reconstituting languages (pp. xi-xv). Clevedon: Multilingual Matters.

Goodwin, C. (2007). Participation, stance and affect in the organization of activities. Discourse \& Society, 18, 53-73.

Hall, J. K. (2004). Language learning as an interactional achievement. The Modern Language Journal, 88(4), 607-612.

Hellermann, J. (2008). Social actions for classroom language learning. Clevedon: Multilingual Matters.

Heritage, J. (2007). Intersubjectivity and progressivity in person (and place) reference. In N. J. Enfield and S. Levinson (Eds.), Person reference in interaction: Linguistic, cultural, and social perspectives (pp. 255-280). Cambridge: Cambridge University Press.

Jefferson, G. (2004). Glossary of transcript symbols with an introduction. In G. H. Lerner (Ed.), Conversation Analysis: Studies from the first generation (pp.13-31). Amsterdam/ Philadelphia: John Benjamins.

Lüdi, G. (2006). De la compétence linguistique au répertoire plurilingue. Bulletin suisse de linguistique appliquée, 84, 173-189.

Markee, N. (2000). Conversation analysis. Mahwah, NJ: Lawrence Erlbaum.

Markee, N. (2008). Towards a learning behavior tracking methodology for CA-for-SLA. Applied Linguistics, 29(3), 404-427.

Masats, D., Nussbaum, L., \& Unamuno,V. (2007). When activity shapes the repertoire of second language learners. EUROSLA Yearbook, 7, 121-147. 
Moore, E., Borràs, E., \& Nussbaum, L. (2013). Plurilingual resources in lingua franca:An interactionist perspective. In H. Haberland, D. Lønsmann, \& B. Preisler (Eds.), Language alternation, language choice and language encounter in international university education (pp. 53-84). Dordrecht: Springer. DOI: 10.1007/978-94-007-6476-7_3.

Moore, E., \& Nussbaum, L. (2011). Què aporta l'anàlisi conversacional a la comprensió de les situacions d'AICLE. In C. Escobar \& L. Nussbaum (Eds.), Aprendre en una altra llengua/ Learning through another language/ Aprender en otra lengua (pp. 93-117). Bellaterra: Servei de Publicacions de la UAB.

Moore, E., Nussbaum, L., \& Borràs, E. (2013). Plurilingual teaching and learning practices in 'internationalised' university lectures. International Journal of Bilingual Education and Bilingualism, 16 (4), 471-493, DOI: 10.1080/13670050.2012.702724.

Nilsson, B. (2003). Internationalisation at home from a Swedish perspective. Journal of Studies in International Education, 7, 27-40

Nussbaum, L., Moore, E., \& Borràs, E. (2013). Accomplishing multilingualism through plurilingual activities. In A. C. Berthoud, F. Grin \& G. Lüdi (Eds.), Dylan Book. Amsterdam: John Benjamins.

Nussbaum, L., \& Unamuno, V. (2000). Fluidité et complexité dans la construction du discours entre apprenants de langues étrangères, Acquisition et Interaction en Langue Etrangère, 12, 27-49.

Pekarek Doehler, S. (2009). Mediation revisited: The interactive organization of mediation in learning environments. Mind, Culture, and Activity, 9(1) 22-42.

Sacks, H. (1972). An initial investigation of the usability of conversational materials for doing sociology. In D. Sudnow (Ed.), Studies in Social Interaction (pp. 31-74). New York: Free Press.

Sacks,H. (1992). Lectures on conversation. Edited by G.Jefferson. Cambridge, MA:Blackwell Publishers.

Sacks, H., Schegloff, E.A., \& Jefferson, G. (1974). A simplest systematics for the organization of turn-taking for conversation. Language, 50(4), 696-735.

Schegloff, E. A. (2007). Sequence organization in interaction: A primer in conversation analysis (Vol. 1). Cambridge: Cambridge University Press.

Seedhouse, P. (2004). The interactional architecture of the language classroom: A conversation analysis perspective. Malden, MA: Blackwell.

Seedhouse, P., \& Almutairi S. (2009). A holistic approach to task-based interaction. International Journal of Applied Linguistics, 19(3), 311-338.

Swain, M., \& Lapkin, S. (2000). Task-based second language learning: The uses of the first language. Language Teaching Research, 4 (3), 251-274. 


\title{
Multimodality in English medium higher education
}

\author{
Joan Ploettner
}

\section{Introduction}

Certification processes to teach in English vary widely among higher education institutions (Dearden and Macaro, 2016) and current requirements have been questioned by some scholars. Although a C1 level of general English competency on the Common European Framework of Languages (CEFR, Council of Europe, 2001) is frequently recommended, it is important to note that general language proficiency tests do not assess specific language knowledge and skills that form the foundation for teaching content in English Medium Education in Multilingual University Settings (EMEMUS). Also, research has shown that meaning is co-constructed in classrooms through a variety of embodied and plurilingual resources beyond that of the target language (Ploettner, 2019). Despite this, current teacher certification processes focus on linguistic skills in the target language, passing over the full meaning-making repertoire of EMEMUS teachers. Finally, certification processes do not consider the type of content being taught. Teaching professionally-related practical skills relies heavily on a repertoire of embodied meaning-making resources in addition to the target language. Whereas teaching abstract theoretical content in English may require broad knowledge and skills in the target language, teaching practical skills may not. In summary, teacher certification based solely on general target language knowledge questionably reflects a teacher's ability to co-construct meaning and learning opportunities in the EMEMUS classroom and suggests the need to move away from monolingual ideologies on language learning in multilingual milieus.

The negative impact of monolingual ideologies on plurilingual education is well documented.Vallejo and Dooly (2020) suggest that such ideologies not only devalue the fluent and hybrid communicative practices of multilingual speakers, but also result in certification processes that fail to assess plurilingual speakers fairly. Within EMEMUS, monolingual ideologies contribute to a lack of recognition of the full semiotic repertoire involved in teaching university content subjects in English and result in teaching certification processes that disregard the complete set of meaning making resources that come into 
play in EMEMUS. This chapter focuses on multimodal aspects of EMEMUS. It examines plurilingual and embodied semiotic resources involved in the co-construction of meaning and the creation of learning opportunities in EMEMUS classroom interaction. Taking a socio-constructivist perspective on learning, multimodal conversation analysis is applied to study classroom interaction in the teaching of professionally-related practical skills. In order to contextualise the analysis, we will focus on pertinent aspects of physical therapy education before presenting the theoretical framework and the research questions that guide our analysis.

\section{Teaching professionally-related skills in physical therapy}

Socio-constructivist perspectives of learning (Vygotsky, 1978; Lantolf, Thorne and Poehner, 2006), such as the one that frames this study, conceptualise classrooms as spaces in which both shared meaning and opportunities for learning are co-constructed in interaction among the classroom participants. That is, learning is socially situated because it takes place through interaction, and meaning is constructed in the social context in which interaction takes place, often through processes of alignment. Lindström and Sorjonen (2013) conceptualise aligning actions as recipient responses that support the structure of an activity that is co-constructed in interaction. Conversely, non-aligning actions are recipient responses that do not support the ongoing co-constructed activity. In the data presented here, the co-constructed activity involves the teaching and learning of correct positioning for a rehabilitation exercise and aligning participant actions support the progressivity of this ongoing activity.

Physical therapy training prepares students with professionally-related competencies in order to correctly perform rehabilitation exercises. This process involves situated learning in which people with common goals (joint enterprise) become involved together in actions that commit them (mutual engagement) and do so thanks to the display of a shared repertoire of tools, routines, ideas, stories, verbal resources, discursive practices, etc. Learning professionallyrelated skills, then, involves progress in the evolution of knowledge and skills that will allow learners to develop their competence as professionals. As people only learn in practice (Lave, 1996), learning is only possible when learners accomplish goal-directed actions. Lave and Wenger (1991) point out that the novice members of a community (in this case physical therapy students) participate with expert members of the community (in this case a physical therapy university instructor) in actions that allow them to acquire skills, tools and the resources that will serve them to become experts (in this case professional physical therapists). At first, the actions that learners can do are limited, but, through practice, they acquire the necessary expertise to progress beyond a limited (peripheral) participation as novice learners towards full participation in the community. 
Goffman's $(1974,1981)$ notion of 'participation frames' is a dynamic construct that makes it possible to describe goal-directed actions from an emic perspective and account for the different activities teachers and learners carry out in the classroom. Masats (2008), in her study of pair-work interaction in task-based learning, distinguishes three types of participation frames, namely the 'frame of task direction' (teachers instruct students prior their engagement in a task), the 'frame of task execution' (the students are on task) and the 'frame of monitoring action' (the task is momentarily abandoned to repair a communication breakdown). According to this author, the structure of participation and the goal-directed actions participants engage in is what distinguishes one frame from the other. For example, in the 'frame of task execution', when the students are working in pairs to achieve the goals of the task, they typically share the role of 'ratified speakers' (Goffman, 1981) while the teacher voluntarily and momentarily adopts the role of 'bystander' (Goffman, 1981). The teacher, though, may decide to intervene to correct an action or help students solve a communication breakdown and, thus, adopts again the role of 'ratified speaker', which modifies the structure of participation: both students and their teacher become ratified speakers and the latter adopts an expert role. As Borràs et al (2012) argue, Goffman's model is important to understand participation but it fails to envisage speakers and hearers as co-participants in a common situated activity. In this sense, Goodwin and Goodwin (2004: 222) point out:

speakers attend to hearers as active co-participants and systematically modify their talk as it is emerging so as to take into account what their hearers are doing. Within the scope of a single utterance, speakers can adapt to the kind of engagement or disengagement their hearers display through constant adjustments of their bodies and talk.

The sequence examined in this chapter reflects one activity in the training process in which students are taught to correctly perform rehabilitation exercises. The training process involves an initial verbal explanation of an exercise by the teacher-specialist along with a demonstration of the correctly performed exercise with a volunteer student acting as a patient. A second step encompasses practice, or the re-enactment of the exercise in student pairs, accompanied by individual assessment and correction on the part of the teacher-specialist. Participation in this process, as Goodwin and Goodwin (2004) suggest, is enacted multimodally, through both verbal and non-verbal (gaze, gestures, manipulation of objects, etc.) resources.

\section{Methodology}

The data presented in this chapter were collected in the health sciences faculty at a private university in Catalonia, Spain. A pilot project was introduced at the request of the content specialist, who stated she would like to try teaching in 
English despite her limited English competency (approximately A2-B1 proficiency level as described in the CEFR). A modified tandem-teaching format was adopted in which the English language expert (the author of this chapter) was present in the classroom as a resource in the case of linguistic difficulties, while the content specialist carried out the bulk of teaching. The English language expert was also responsible for the filming of the session.

All participants signed a written informed consent allowing the recording of the classroom interactions. The recordings were reviewed by the authorresearcher of this study and relevant sequences were selected for transcription and analysis. The selected recordings were transcribed using adapted multimodal conversation analysis conventions. Due to lack of space, only one representative sequence is presented here. It comprises a correction sequence in which the content teacher interacts with a student pair that is practicing correct positioning. This clinical training session involved the teaching of an exercise used in rehabilitation of neurologic patients. The students and the teacher had already carried out a series of similar clinical training sessions in Spanish, based on a similar type of didactic sequence that involved a lecture-demonstration of correct positioning and movement followed by supervised student practice in pairs. Thus, they had a shared understanding of the sequential organisation of the classroom teaching session.

In addition to examining plurilingual practices, we conduct a multimodal conversation analysis of data, which focuses on the different meaning-making resources and aligning recipient actions undertaken by the students and their teacher. Thus, our analysis focuses both on the various semiotic resources that are involved in the co-construction of meaning and learning opportunities in interaction. Specifically, the following questions are addressed:

- What semiotic resources are mobilised in English medium education aimed at teaching professionally-related practical skills?

- How is the co-construction of meaning visible in interaction in English medium education aimed at the teaching of professionally-related practical skills?

Our analysis was subsequently revised in data sessions with informed experts.

\section{Analysis and discussion}

In the sequence prior to the one we examine here, students were practicing the correct positioning for a rehabilitation exercise. They worked in pairs and, while one of them assumed the role of the physical therapist, the other adopted the role of patient. The exercise and positioning had been demonstrated previously to the students by the teacher. During the demonstration the content teacher had explained that, with the patient in the lying position on the plinth, if the legs of the patient separated due to low muscle tone, a bandage could 
be placed around the legs to maintain them in the correct position. Similarly, if the patient's knees pressed together during the execution of the exercise, a rolled-up towel could be placed between the patient's knees to maintain the correct position.

While the students were conducting the task the content teacher circulated around the classroom to observe and correct student performance. The English language specialist filmed the interactions with a hand-held camera and intervened occasionally, providing linguistic support when necessary.

In the sequence, the student who has assumed the role of physical therapist, student 1 , is standing at the foot of the plinth. The student who has assumed the role of patient, student 2 , is lying on the plinth. An additional participant in the interaction is student 3, a 'bystander', who is practicing with a partner at a nearby plinth. The three students involved in this interaction all share French as an L1. A change in the participation frame occurs when the content specialist (T/CS) approaches the plinth where the students are practicing and intervenes, as we can see in excerpt 1.

Excerpt 1. Participants: Content specialist teacher (T/CS), student in the role of physical therapist (ST1), student in the role of patient (ST2) and bystander student (ST3)
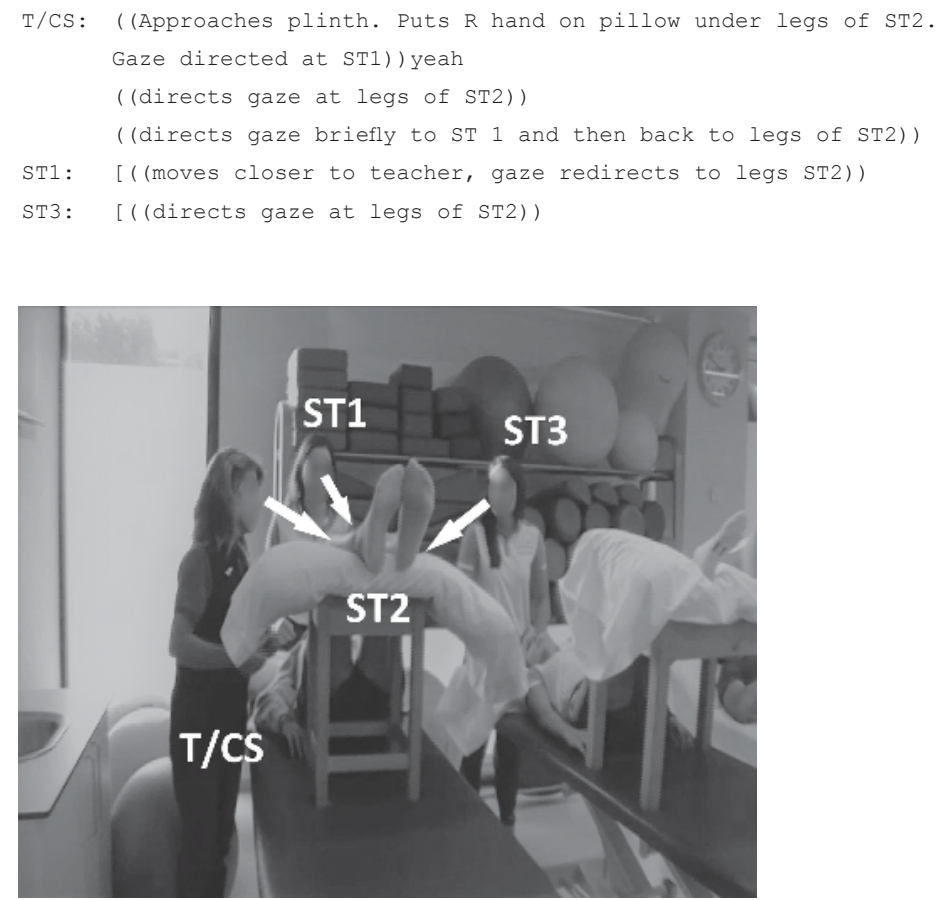

Figure I0.I Coordinated gaze at areas of interest (lines 3-6) 
7 T/CS: here

8 ((puts hands on knees of ST2))

In excerpt 1 the content teacher moves toward the plinth. With the action of putting her right hand on the pillow under the legs of ST2 (line 1), she is enacting a change in the participation frame, from what Masats (2008) refer to as the 'frame of task execution' (when ST1 and ST2 were on task practicing the correct positioning for a rehabilitation exercise) to the 'frame of monitoring action' (correction and modelling of what students are expected to do). Her action of directing gaze at ST1 (line 2) signals the initiation of this action. Her utterance "yeah" (line 2) coincides with direction of the content teacher's gaze toward the legs of student 2, focusing attention on this specific area of interest (line 3). Recruitment of ST1's attention begins in line 4 with a redirection of her gaze briefly to student 1 and then back to legs of student 2. Alignment is reflected in student 1's embodied actions of moving closer to the teacher and redirection of her gaze toward the legs of student 2 (line 5). At this point student 3 also directs her gaze at the area of interest (line 6) and all three participants look at the legs of ST2 (see Figure 10.1). In line 7 the content specialist's use of the deictic "here" and her placement of her hands on the knees of student 2 (line 8) signal the location of the incipient instruction.

The content specialist teacher had previously demonstrated to the class that a bandage could be placed around the legs to maintain them in the correct position when necessary. This is the focus of her actions in excerpt 2.

Excerpt 2. Participants: Content specialist teacher (T/CS), English language specialist (ELS), student in the role of physical therapist (ST1), student in the role of patient (ST2) and bystander student (ST3)

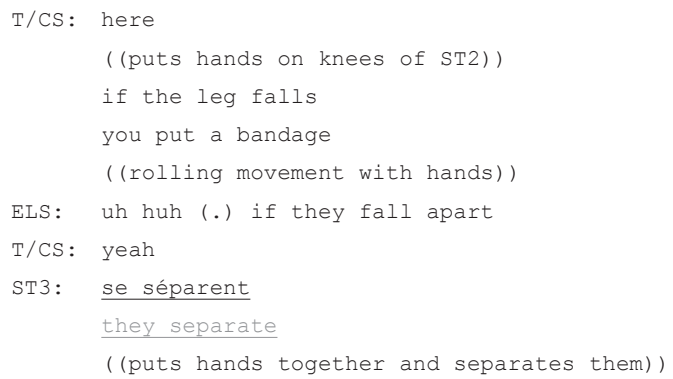




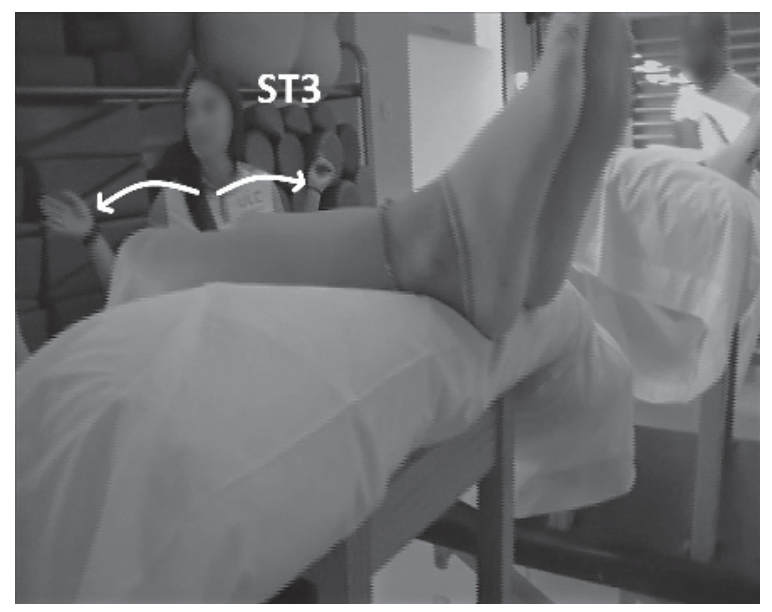

Figure 10.2 Multimodal action of meaning construction (lines 14-15)

16 ELS: yeah

The instruction is comprised of both talk in English (you put a bandage, line 10) and an embodied component (rolling movement with her hands, line 11). This explanation is followed by a heterorepair sequence in which first the English language specialist and then the 'bystander' student participate. The first part of the teacher's instruction ("if the leg falls", line 9) is hetero-repaired in English by the ELS ("uh huh, if they fall apart", line 12)". Her repair action is ratified by the content specialist ("yeah", line 13). Then student 3 , who up to that point had been a 'bystander', uses French ("se separé", line 14) and an embodied gesture (puts hands together and separates them, line 15) to align with the repair action (see Figure 10.2). Ratification of repair by both the language specialist and the content specialist ensues in lines 16 and 17. After that, the monitoring process focuses on a different aspect.

In the demonstration sequence prior to practice the teacher had explained that if the patient's knees pressed together during the execution of the exercise, a rolled-up towel could be placed between them to help maintain the correct position. This is the focus of the interaction which begins in line 18 in excerpt 3 . 
Excerpt 3. Participants: Content specialist teacher (T/CS), English language specialist (ELS), student on the role of physical therapist (ST1), student on the role of patient (ST2) and bystander student (ST3)
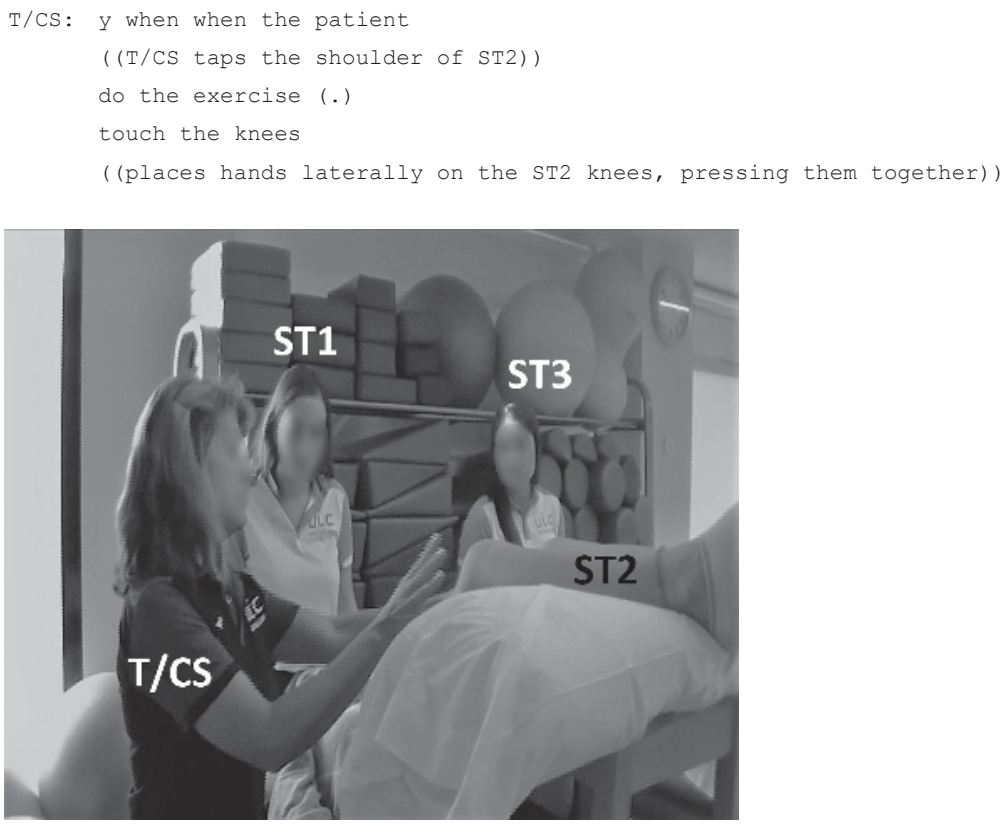

Figure 10.3 Multimodal construction of explanation (lines 21-22) 


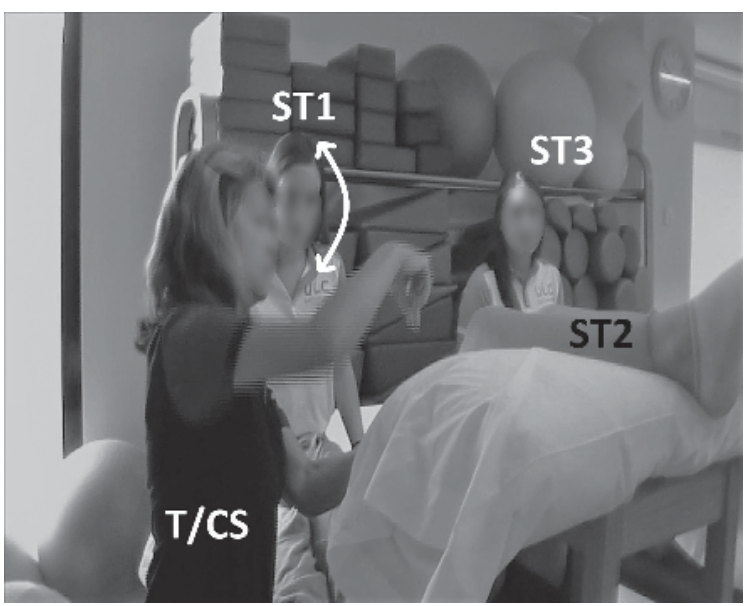

Figure 10.4 Alignment with embodied actions: STI nodding (line 25)

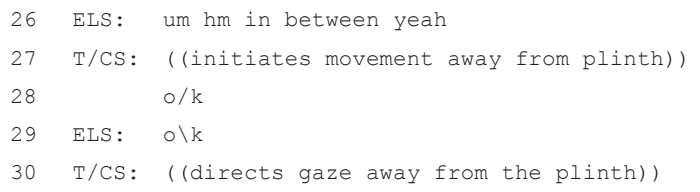

A second instruction sequence begins in line 18. Again, it is developed through multimodal turns. The verbal component ("when the patient do the exercise, touch the knees, put a towel", lines 18, 20, 21 and 23) is accompanied by a gesture (the content specialist teacher taps the shoulder of ST2, line 19) that signals student 2 as the patient in the instruction. Other embodied actions on the part of the content teacher include manipulation of student volunteer's knees to signify contact between knees in line 22 (see Figure 10.3) and the placement of a rolled-up towel between the knees, line 24, T/ CS Rolling gesture in front of knees of ST2. Student alignment in the co-construction of meaning in this part of the sequence is reflected in the nodding gesture of ST1 in line 25 (see Figure 10.4). Finally, the formulation of this second instruction is completed by the language specialist, who, in line 26 , adds verbal information to the utterance formulated by the teacher through verbal (line 23) and nonverbal (line 24) actions.

This last exchange between the content specialist teacher (gaze to ST1 and gestures to indicate how to maintain the correct position of ST2/patient, line 24) and ST1 (nodding as signalling she accepts the correction and understands how to proceed, line 25), completed verbally by the language specialist (line 26) closes the sequence and triggers a change in the participation frame. This shift, from what Masats (2008) names the 'frame of monitoring action' (when 
the teacher corrected ST1 actions and modelled a behaviour) to the 'frame of task execution' (when ST1 and ST2 re-engage in the task practicing the correct positioning for a rehabilitation exercise) begins with the embodied action in line 27, when the content specialist initiates movement away from the plinth. Redirection of the content specialist gaze away from the plinth in line 30 also reflects the closure of the correction sequence.

In summary, the sequential analysis of the correction sequence presented here illustrate that participants' alignment to verbal and embodied actions lead to the co-construction of meaning generating opportunities for learning. In the 'frame of task execution' (Masats, 2008), when students are working in pairs, they take the discursive roles of 'therapist' (ST1) and 'patient' (ST2), but in the 'frame of monitoring action' (Masats, 2008), when the content teacher intervenes to correct ST1's performance, the latter abandons the role of 'therapist' and adopts the role of 'apprentice'. In this case, her participation is 'peripheral' (Lave and Wenger, 1991) and limited to the observation of the actions performed by the content specialist teacher in her role of 'expert therapist'. At this point ST3 abandons her role of 'peripheral bystander' (Goffman, 1981) to participate in this process of meaning making and of knowledge construction as another 'apprentice' in this community of practice (Lave and Wenger, 1991; Wenger, 1998). Finally, we have observed that participants' resources involved in the co-construction of meaning are multimodal in nature and include plurilingual utterances, gaze, gesture, proxemics and the manipulation of the body of ST2.

\section{Conclusions}

The data presented here demonstrate the multiple plurilingual and embodied resources involved in the co-construction of meaning in an EMEMUS context. Participants' aligning actions reflect the co-construction of meaning in interaction. Notably, the target language used in this interactional sequence consists of short, disconnected utterances. A teacher who, on the basis of her knowledge and skills in the target language, would potentially be excluded from EMEMUS has used her full meaning-making repertoire (composed of a variety of multimodal resources) to successfully contribute to the construction of meaning when teaching professionally-related practical skills.

Although we have only analysed a single conversational sequence, our sequential multimodal microanalysis of naturalistic classroom interaction has offered evidence of the vital role of multimodal resources in EMEMUS settings, an aspect easily overlooked to qualify teachers. As discussed earlier, EMEMUS teacher certification processes based only on target language knowledge and skills may fail to recognise the full semiotic repertoire involved in teaching university content subjects in English. We do not wish to suggest that certification processes should ignore target language skills and knowledge, but rather the role of multimodal and plurilingual resources should also be considered. Future 
research should be aimed at analysing a collection of interactional data from this and similar contexts. Such research may prove useful in the design of teacher certification processes that assess more accurately the ability content teachers need to possess to teach EMEMUS subjects.

\section{References}

Borràs, E., Moore, E., Nussbaum, L., \& Patiño, A. (2012) Emergence de modes plurilingues dans des cours universitaires en L2. In L. Mondada \& L. Nussbaum (Eds.), Interactions cosmopolites: L'organisation de la participation plurilingue. Limoges: Editions Lambert Lucas.

Council of Europe (2001). Common European framework of reference for languages: Learning, teaching, assessment. Strasbourg: Council of Europe Publishing.

Dearden, J., \& Macaro, E. (2016). Higher education teachers' attitudes towards English medium instruction: A three-country comparison. Studies in Second Language Learning and Teaching, 6(3), 455-486.

Goffman,E.(1974). Frame analysis:An essay on the organisation of experience. Harmondsworth: Penguin Books.

Goffman, E. (1981). Forms of talk. Philadelphia: University of Pennsylvania Press.

Goodwin C., \& Goodwin, M. H. (2004). Participation. In A. Duranti (Ed.), A companion to linguistic anthropology (pp. 222-244). Oxford: Basil Blackwell.

Lantolf, J., Thorne, S. L., \& Poehner, M. (2006). Sociocultural theory and second language development. In B.Van Patten \& J. Williams (Eds.), Theories in second language acquisition (pp. 197-220). New York: Routledge.

Lave, J. (1996). Teaching, as learning, in practice. Mind, Culture and Activity, 3(3), 149-164.

Lave, J., \& Wenger, E. (1991). Situated learning: Legitimate peripherical participation. New York: Cambridge University Press.

Lindström, A., \& Sorjonen, M. L. (2013). Affiliation in conversation. In J. Sidnell \& T. Stivers (Eds.), Handbook of conversation analysis (pp. 350-369). Chichester: John Wiley.

Masats, D. (2008). El discurs dels aprenents d'anglès com a llengua estrangera: Una aproximació interactivista al procés de construcció de tasques comunicatives. (Unpublished Doctoral thesis). Universitat Autonona de Barcelona, Bellaterra.

Ploettner, J. (2019). Professional development and the interactional accomplishment of EMI expertise. (Unpublished Doctoral thesis). Universitat Autonona de Barcelona, Bellaterra.

Vallejo, C., \& Dooly, M. (2020). Plurilingualism and translanguaging: Emergent approaches and shared concerns. Introduction to the special issue. International Journal of Bilingual Education and Bilingualism, 23(1), 1-16.

Vygotsky, L. S. (1978). Mind in society: The development of higher psychological processes. Cambridge, MA: Harvard University Press.

Wenger, E. (1998). Communities of practice: Learning, meaning and identity. Cambridge: Cambridge University Press. 


\title{
"How do the apples reproduce?" \\ Mediation-in-interaction in a university CLIL course
}

\author{
Emilee Moore
}

\section{Introduction}

European universities have been immersed for several decades in processes of internationalisation. As part of these, English has been introduced through different pedagogical strategies in non-language subjects across university faculties. This approach, with different nuances, has been referred in higher education research as Content and Language Integrated Learning (CLIL), Integrated Content and Language in Higher Education (ICLHE) and English as a Medium of Instruction (EMI), among other terms.

In this chapter, multimodal data from a Science Education subject taught in English at a Catalan university, collected as part of the Language Dynamics and Management of Diversity (DYLAN) project, is presented and analysed. The contribution is driven theoretically by the notion of mediation-in-interaction, inspired by sociocultural learning theory and Ethnomethodology (EM) / Conversation Analysis (CA). The analysis is mainly concerned with how student participants in a particular sequence of classroom interaction: (1) define the 'problems' to be solved and (2) define and make use of different resources (artefacts, concepts, etc.) in the mediational process; thereby shaping and regulating the context and course of their learning. The chapter continues in the next section with an introduction to the main theoretical foundations for the analysis. The methodology for data collection and analysis is presented in the ensuing section. Then we provide a detailed analysis of a sequence of interaction, which is followed by the main findings emerging from the analysis.

\section{Mediation-in-interaction, regulation and resources}

The notion of mediation - "a process through which humans deploy culturally constructed artefacts, concepts and activities to regulate (i.e. gain voluntary control over and transform) the material world or their own and each other's social and mental activity" (Lantolf and Thorne 2006: 79) - has been well developed in sociocultural theories of learning. Contributing to 
this theorisation from a strongly interactionist perspective (i.e. influenced by both sociocultural and EM / CA theories), Pekarek Doehler (2009) proposes the term 'mediation-in-interaction' for investigating how the meaning and affordances of different elements contributing to mediational processes artefacts, concepts, activities, selves, others, etc. - are constructed in interaction. She claims:

[L]ittle attention has been paid to the ways social interaction and the related coordination of activities and cognitive efforts contribute to creating the task at hand, to defining the problem to be solved, and thereby to shaping the very context of learning and development.

(Pekarek Doehler 2009:23)

In the data analysed, taken from a Science Education university class taught, according to the lecturer, following CLIL methodology (i.e. students' learning of both primary school Science and English were explicit course objectives), participants orient their activities to both linguistic (i.e. English as an additional language) and scientific (i.e. primary school Science) learning objects. In this regard, Barwell's (2003, 2005) CA-inspired notions of attention, sequentiality and reflexivity are used for exploring how linguistic and scientific problems are identified, unfold and are resolved as students collaborate on a classroom task. In his research, Barwell shows how learners' attention to problematic aspects of mathematics content in a bilingual classroom constructs the sequential context for their attention to language problems, and vice versa. Similarly, Gajo (2007) explores how language problems - what he calls opacity - and science problems - what he calls density - are conceptualised and clarified in mediational processes in bilingual classrooms. Gajo's (2007) main argument is that rather than being a burden, linguistic opacity can be considered an advantage for tackling scientific density. He claims that language problems render scientific problems that might otherwise go unnoticed visible - they are "both aspects of the same phenomenon" (Gajo 2007: 568), which is what Barwell refers to when speaking of reflexivity.

Closely related to the notion of mediation is that of regulation, which in interactionist research is also referred to as facilitation (e.g. Alber and Py, 1985). According to sociocultural theory, there exist three types of regulation: objectregulation, other-regulation and self-regulation. Object-regulation concerns the role of physical resources in the environment when mediating one's cognitive activity. Interactional studies in various settings have been essential to understanding how participants mutually arrange their bodies and gaze around aspects of their environment, and how objects create a locus for the organisation of individual and shared attention and action (e.g. Goodwin, 1994, 1995). The second form of regulation, other-regulation, refers to explicit or implicit assistance or direction from someone more expert in carrying out a 
task - closely related to the well-known sociocultural notions of the zone of proximal development (ZPD) and scaffolding. From an interactionist perspective, Seedhouse (2004) shows how the ZPD and scaffolding can be traced in the local organisation of interaction, for example in repair sequences (Schegloff, Jefferson and Sacks, 1977). CA research on word searches in particular (e.g. Hayashi, 2003) has systematically shown how communicative and cognitive difficulty may be displayed and transformed into a shared activity by participants through verbal features such as cut-offs and sound stretches, as well as by using other multimodal resources such as gaze and gesture. Related research on embodied completions (Mori and Hayashi, 2006) (i.e. using a gesture to complete a turn) has described how gesture might be used to compensate for verbal communication trouble and gaining assistance. The third type of regulation, self-regulation, describes the ability to control one's cognition and actions without external support. Such self-regulation may be verbalised as a sort of 'thinking aloud' (e.g. Lantolf and Thorne, 2006) or traced in people's written activity (e.g. Pitsch, 2005; Moore, 2014).

Extensive research has shown how learners' developing plurilingualism, mobilised in procedures described as translanguaging, code-switching, etc., is a resource for interacting and for regulating learning (Moore, 2014; Llompart et al, 2020). This is also the case in the data analysed in this chapter, to which we now turn.

\section{Methodology}

The data presented in this chapter was collected as part of the DYLAN project, an interdisciplinary European Sixth Framework project that ran from 2006 to 2011. The GREIP team carried out research at two public universities in Catalonia undergoing processes of internationalisation in order to understand the relationship between multilingual policies and local practices in different settings (classrooms and elsewhere on campus). The study was primarily driven by the methodological principles of EM and CA, as well as drawing on methods from Linguistic Ethnography (LE) in gaining access to different research sites and collecting data. The data corpus studied was multimodal, including audio- and video-recorded natural interactions, and written artefacts that come into play in the interactions, as primary sources for analyses, as well as official documentation (e.g. course guides, university policies) and interviews (e.g. with teachers and students), which were treated as secondary sources drawn on indirectly to complement, rather than to determine, the analyses of interaction.

More specifically, data from a subject offered by the Faculty of Education at one of the universities studied is focused on in this chapter. Science Education was a compulsory subject for first year university students who were preparing to be primary school teachers, specialising in foreign languages. The subject consisted of weekly lectures led by the professor in English with the 


\title{
LABWORK ACTIVITY $N^{\circ}$ 2: \\ WHAT CAN STUDENTS LEARN FROM AN APPLE?: THE GOALS OF SCIENCE EDUCATION
}

\begin{abstract}
Science teachers like to teach the topic of fruits in primary education. Children are usually asked to take fruits from home and observe them. There are many ways to teach science from an apple. This activity aims at helping you reflect on what are the goals of science education while observing yourselves an apple and thinking about the best questions to guide students' work.

a) Take three diferent apples and observe them carefully

b) Write a list of good questions related to an apple you would ask children in a science classroom

c) Read the list of "Specific Goals of Science Education 5-12" attached and relate the questions you have written to those goals.

d) What view of science were your questions reflecting?
\end{abstract}

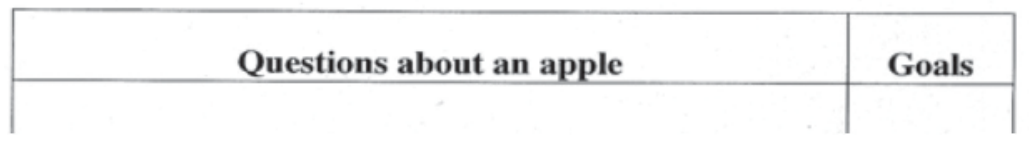

Figure II.I Task instructions handout

entire class group, followed by practical sessions in a science laboratory with half of the class at a time. The data presented in this chapter was collected in a Science laboratory session in the second week of the semester and involved a group of five students. The students had chosen their own groups on the first day of class.

On entering the laboratory, students found some photocopies from an English language Science dictionary, some apples and a double-sided handout in English explaining the task (see Figure 11.1) on the bench. In the interactional sequence analysed in this chapter, students were working on the second task on their handout; they had to formulate questions that could be asked to primary school pupils about the apples. The students completed the handout individually based on the agreements reached during the group work interaction and presented their responses to the class, before submitting the completed handout to the professor for grading.

\section{"How do the apples reproduce?"}

The analysis explores how the focal group (see Figure 11.2) collaboratively formulates one question about the 'reproduction' of apples, which has been circled by the author in Figure 11.1. Some of the fragments of interaction continue from the previous one, as explained in the presentation of each of them, despite being numbered separately. The sequence begins in excerpt 1 with one group member, Sandra, reading the task instructions. Both Sandra and Laia, another student in the group, then compete for the floor, posing different candidate questions. 


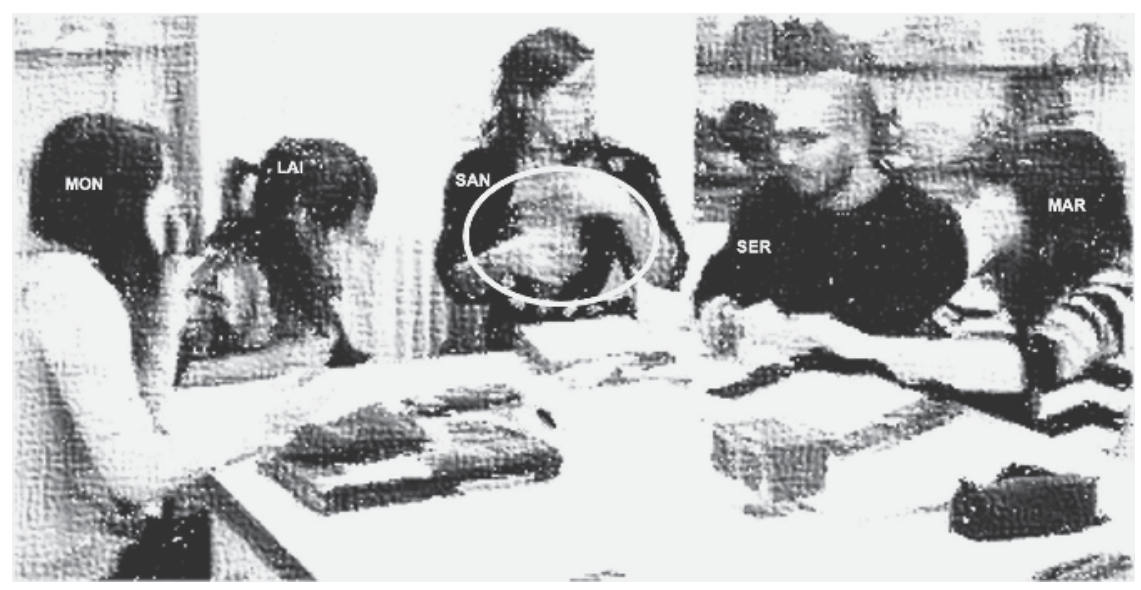

Figure II.2 Sandra moves her hands in a circular motion (circled) in line 8 of excerpt I

Excerpt 1. Participants: Mònica (MON), Laia (LAI), Sandra (SAN), Sergi (SER) and Maria (MAR)

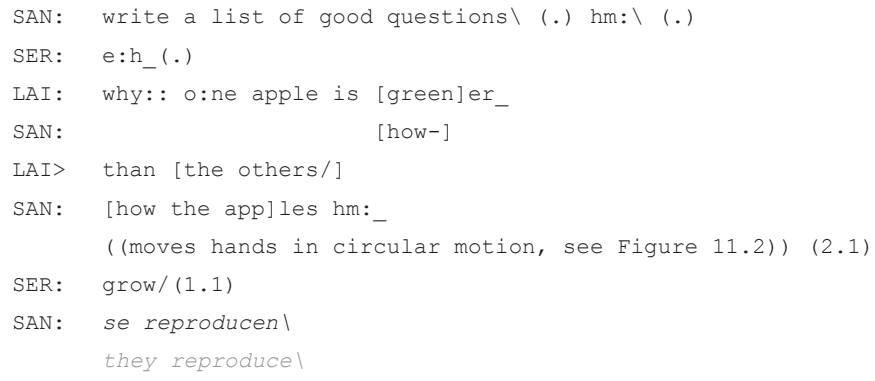

Sandra - in line 6 - displays trouble in expressing her idea. She looks at Sergi and moves her hands in a circular motion (Figure 11.2), thereby sharing the trouble. After a two-second silence, Sergi suggests the verb "grow". However, this is not the verb Sandra is seeking; thus she draws on a different resource, using Spanish in order to clarify what she is trying to say ("se reproducen"). Following this, a loud noise opens a side-sequence - which has been omitted as it is not relevant to the analysis - in which the students laugh and comment on the interruption.

Several turns later in excerpt 2, Sandra recasts her suggestion. 
Excerpt 2. Participants: Mònica (MON), Laia (LAI), Sandra (SAN), Sergi (SER) and Maria (MAR)

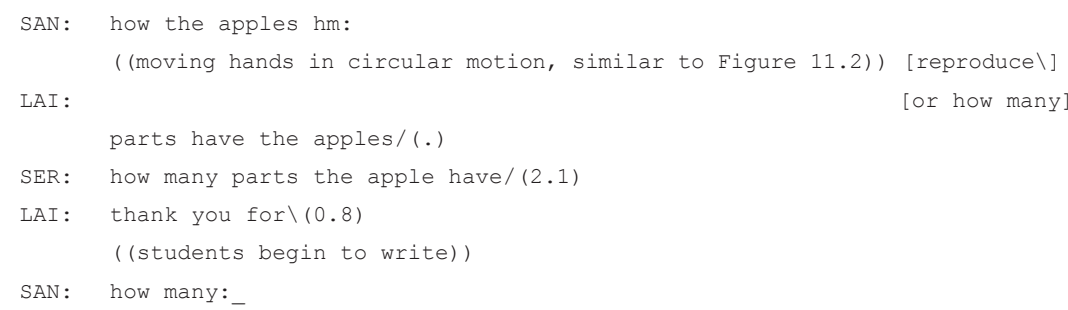

Sandra again orients to trouble, repeating the circular movement with her hands as she suggests the verb "reproduce" (line 2). However, Laia suggests a different question (line 3-4), which is taken up by Sergi. He reformulates it in line 5, and the group begins to write in line 7 .

Several turns later - in excerpt 3 - the group has finished writing Laia's question. At this point, Sandra gets the floor by emphatically producing a discourse marker ("now") and suggests her idea a third time.

Excerpt 3. Participants: Mònica (MON), Laia (LAI), Sandra (SAN), Sergi (SER) and Maria (MAR)

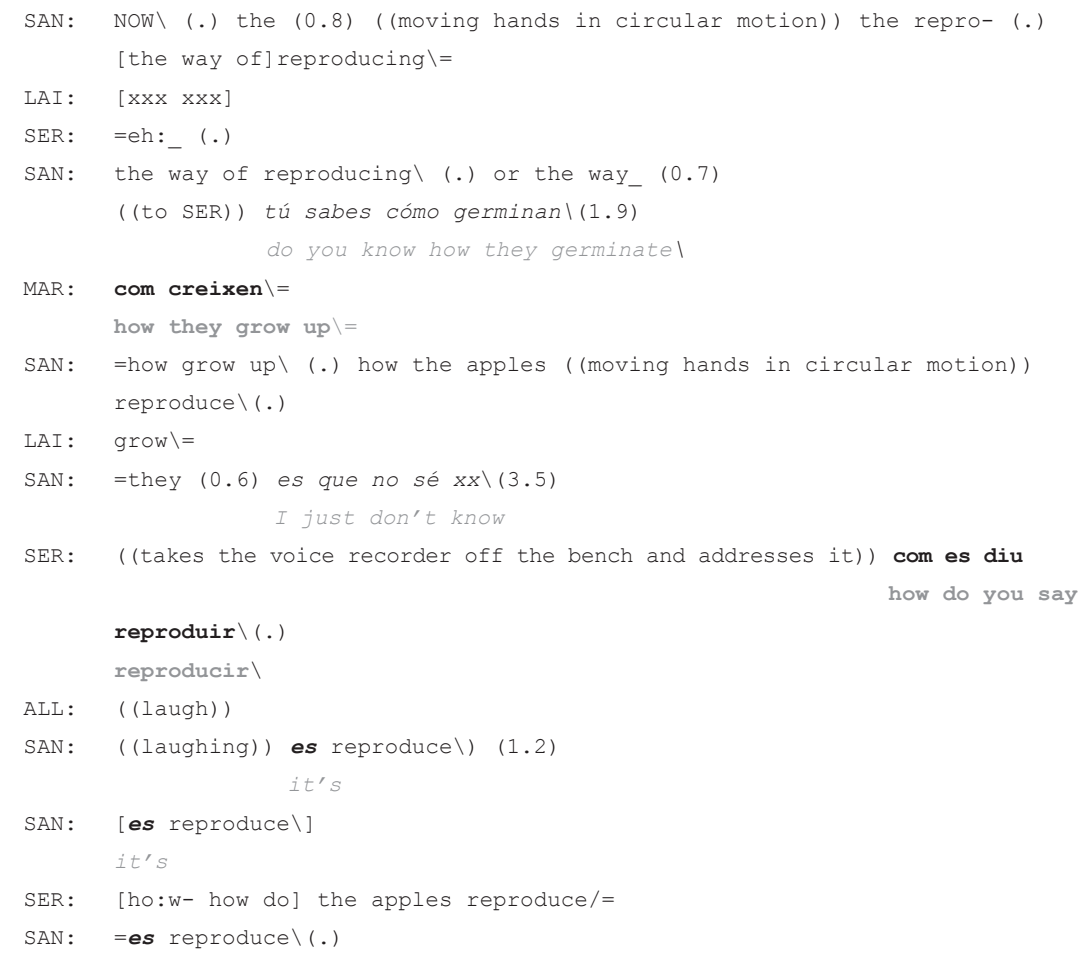


$\begin{array}{lll}19 & \text { MAR: } & \text { [repro]duce/ } \\ 20 & \text { SER: } & \text { [itself/] }(0.8) \\ 21 & \text { SAN: } & \text { ((laughing, looking at SER)) es que este es el problemal }\end{array}$

In lines 1-2 it becomes clear that Sandra's trouble in formulating her idea continues, displayed through her repetition of the circular hand movements, self-interruption and reformulation ("the repro...the way of reproducing"). Sergi displays doubts in line 4. Sandra repeats the idea (line 5), but her "or" cues a search for an alternative way of expressing it. Sandra switches to Spanish in line 6 and looks at Sergi for assistance, referring to the concept of 'germination' ("germinan"). In line 7, Maria introduces another notion - in Catalan - being that of 'growth' ("com creixen"). Sandra translates Maria's turn into English ("how grow up") in her following turn (line 8) and then repeats the question using the verb "reproduce" in line 9. She therefore makes it clear that the problem for her is not just in the translation of the verbs, which she has no problem doing. However, in line 10 Laia proposes the verb "grow"-suggesting that she does interpret the trouble as linguistic.

In line 11 Sandra's search continues. She again switches to Spanish in expressing her trouble. After a few moments of silence, Sergi takes the voice recorder off the table and asks 'it' in Catalan for the translation of the Catalan verb "reproduir". Therefore, he also demonstrates his interpretation of Sandra's difficulty as a linguistic one. Following the subsequent laughter, however, Sandra again displays her knowledge of how to translate the verb into English ("reproduce", lines 15, 16 and 18). Sergi formulates the complete question, "how do the apples reproduce", in line 17. However, Maria (line 19) questions the verb "reproduce". At the same time, Sergi questions whether the verb is reflexive ("itself", line 20). Sandra then tells Sergi - in Spanish - that this is exactly her problem (line 21).

The group, however, commences writing the question on their handouts in excerpt 4 - a direct continuation of the previous fragment.

Excerpt 4. Participants: Mònica (MON), Laia (LAI), Sandra (SAN), Sergi (SER) and Maria (MAR)

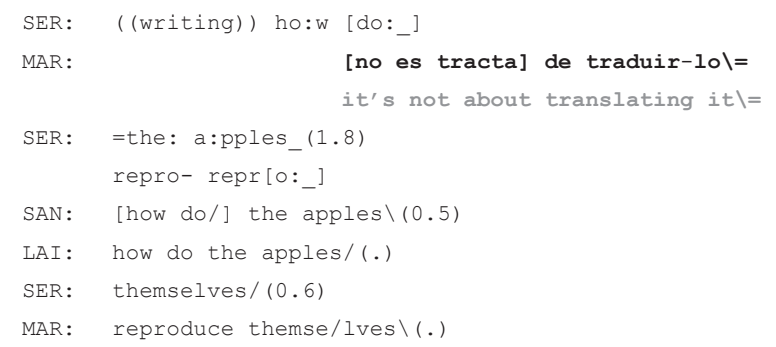




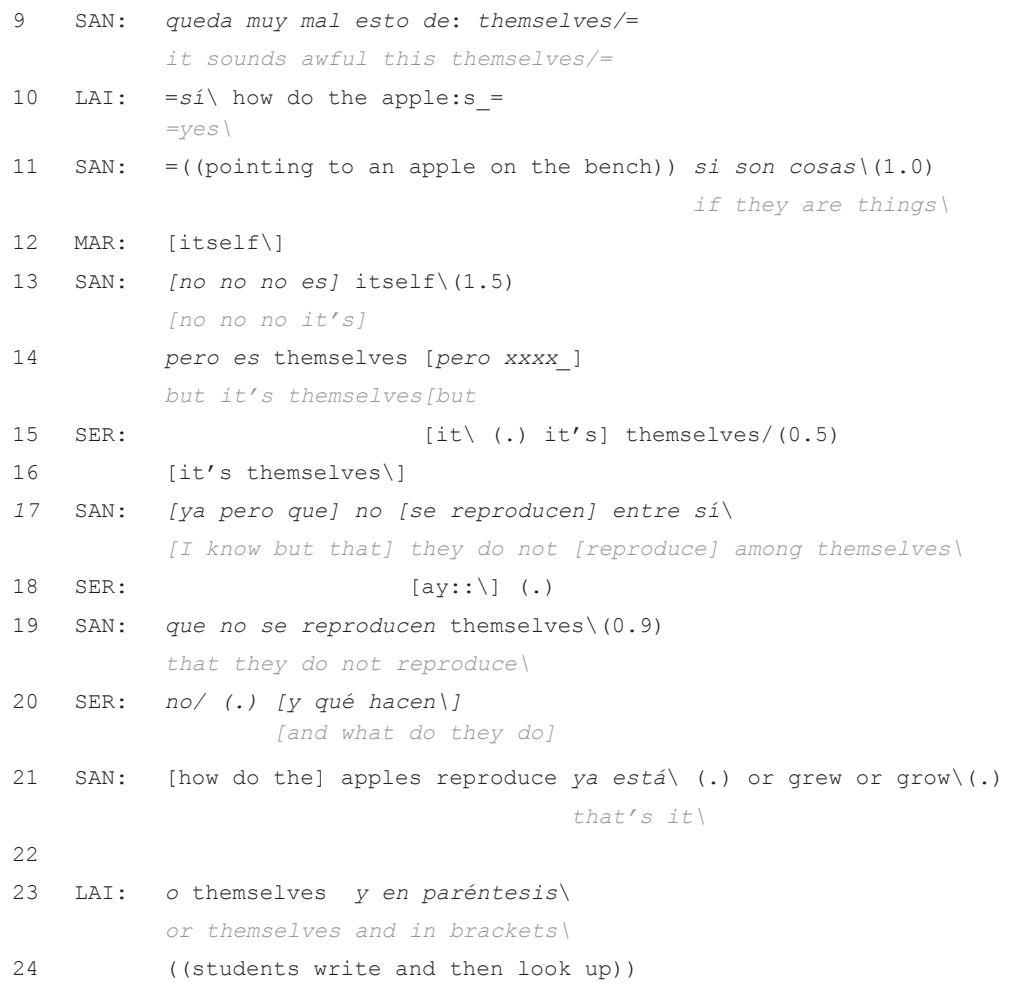

As they write, Sergi verbally modifies his choice of pronoun from "itself" to "themselves". He is focused on the adequacy of the question in terms of the second language (lines 1-7). However Laia, Maria and Sandra are not convinced by Sergi's version of the question. Maria asserts that it is not a matter of simply translating (line 2) and Sandra switches to Spanish in line 9, in order to ask her peers if the formulation sounds correct to them. Laia agrees with her that it does not, and Sandra explains, pointing to the apples, that they are things ("cosas", line 11). It is clear, then, that the cause of Sandra's problem is not linguistic. Rather, she is attending to the scientific adequacy of the formulation in terms of the concept of 'reproduction' itself. In line 12, however, it also becomes apparent that Maria's reason for doubting the formulation of the question is entirely linguistic; she suggests changing "themselves" to "itself". Over the following lines, Sandra's position is made even clearer. While she agrees that the correct pronoun would be "themselves" (lines 13-14), she does not agree with the accuracy of the reflexive form of the verb on scientific grounds ("que no se reproducen entre sí", line 17; "que no se reproducen themselves", line 19). That is, as 'things', apples are not active agents of reproduction in the same way that living beings are. Sandra finally suggests they use a non-reflexive form of the verb ("how do the apples reproduce ya está", line 21) or changing it ("grew or 
grow", line 21) to better express the concept. In line 23, Laia suggests putting "themselves" in parenthesis on their individual handouts.

Excerpt 5 - the direct continuation of excerpt 4 - begins with Sergi reformulating the question entirely. Sandra's contributions, therefore, have successfully prompted a change in his focus.

\section{Excerpt 5}

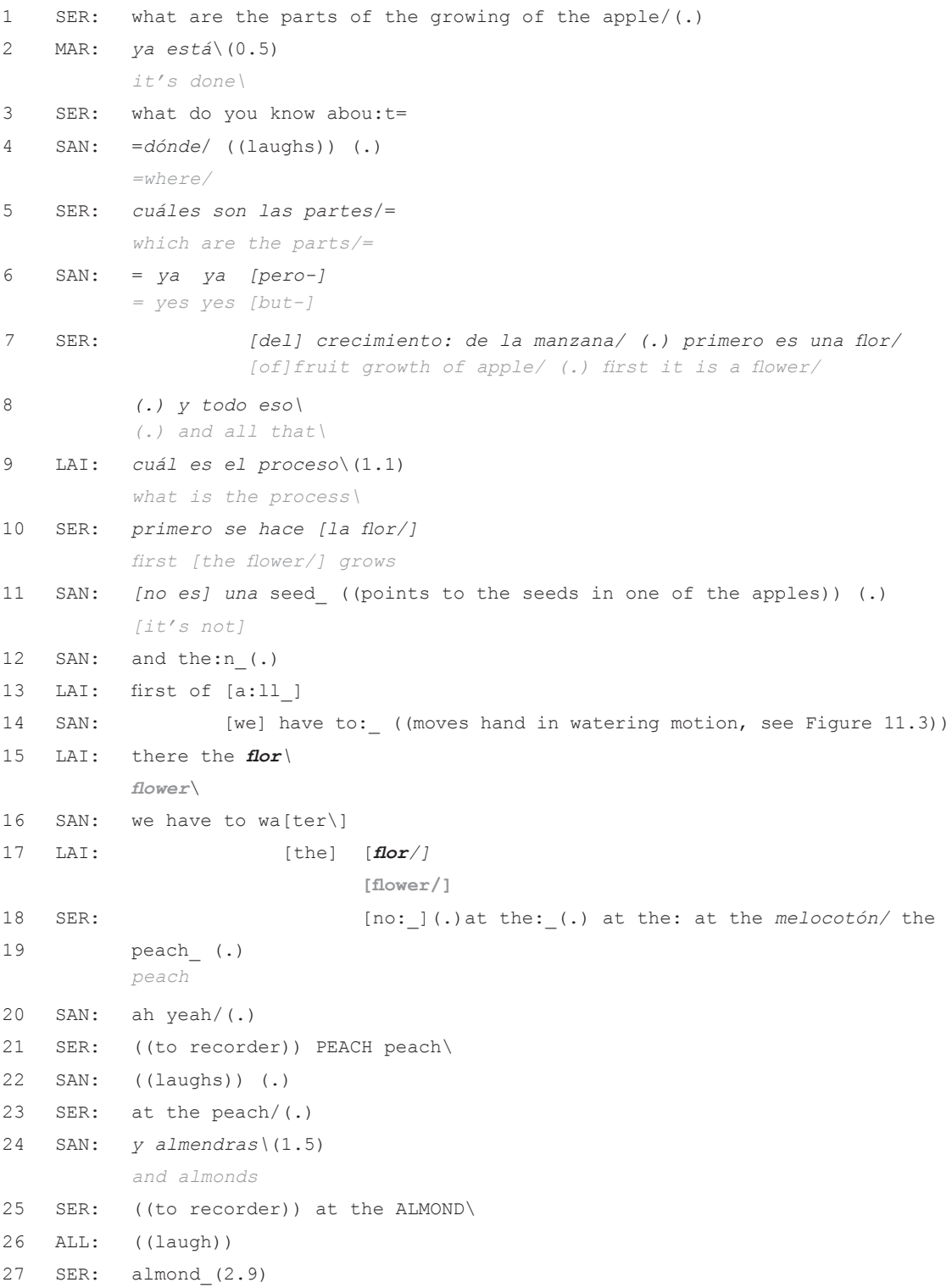




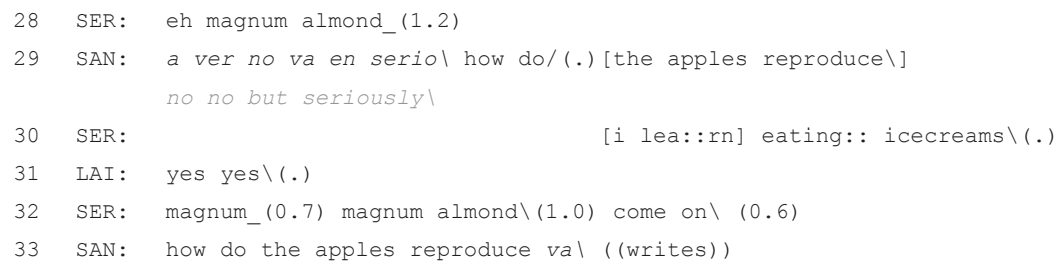

Despite Sergi's complete reformulation of the question, in line 2 Maria urges the group to move on; for her, the negotiation has reached completion. Sergi tries a different lead-in. However, after Sandra displays confusion in line $4-$ in Spanish - he switches to that language, translates, and explains that he is asking about the 'parts of growth' ("las partes del crecimiento", lines 5 and 7). These 'parts', according to him, start with a flower. Laia formulates Sergi's question more scientifically - in Spanish - asking about the 'process' ("el proceso", line 9). In line 10, Sergi reiterates his understanding that the process begins with a flower. However, in line 11 Sandra contradicts him; claiming that the apple starts as a seed. She inserts that word in English and points to the seeds in one of the apples on the table - perhaps to provide evidence for her claim or possibly to facilitate her peers' understanding.

Continuing her explanation of the process, in lines 12 and 14 Sandra displays a new doubt. This is verbalised through her elongation of the vowel and her gesture illustrating the verb "water", which she finds in line 16. Meanwhile, Laia aligns with Sergi's claim that the flower comes first in the reproduction cycle of apples (lines 13,15,17). Not knowing the word for flower, she inserts

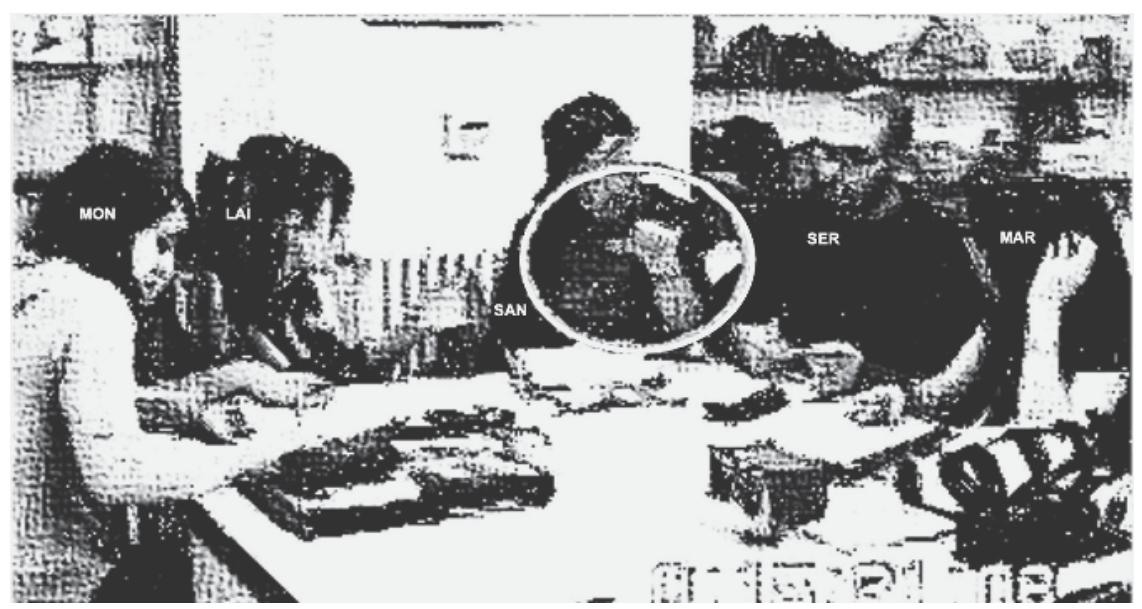

Figure I I.3 Sandra moves her hands in a circular motion (circled) in line 2 I of excerpt 5 
it in Spanish or Catalan; displaying that her focus is primarily on the content. Similarly, in line 18 Sergi appears to search for the word peach, in order to contradict Sandra's argument. Not finding it, he inserts the Spanish equivalent. However, he immediately repairs by producing the English word, then jokingly draws attention to it by repeating the word to the voice recorder. Likewise, when Sandra gives the example of almonds in line 24 - producing the Spanish word - Sergi corrects her. He then repeats the word in English to the audiorecorder and makes a joke about how he knows the word.

In line 29, Sandra produces a turn - in Spanish - in an attempt to get the group back on task and voices her formulation the question. After the joke continues, she repeats her formulation ("how do the apples reproduce", line 33), then produces a discourse marker to move on ("va") and begins to write. Following this, the students begin working on a different question.

Interestingly, the students' completed worksheets, which were collected after the activity, reflected three different ways of formulating the question adopted by them: "how do the apples reproduce" (Maria and Sandra); "how do the apples reproduce themselves" (Sergi); and "how do the apples reproduce (themselves)" (Monica and Laia) (Figure 11.4). Thus, despite focusing on different ways of formulating the question (e.g. "grew or grow" (excerpt 4 line 21),

\begin{tabular}{|c|c|}
\hline Name & Question on handout \\
\hline SER & $\begin{array}{l}\text { 4) How do the apples repnoduce Hemselves? } \\
\text { Transliteration: } \\
\text { 4) How do the apples reproduce themselves? }\end{array}$ \\
\hline SAN & $\begin{array}{l}\text { 4. How de the apples reproduce? } \\
\text { Transliteration: } \\
\text { 4. How do the apples reproduce? }\end{array}$ \\
\hline LAl & $\begin{array}{l}\text { (4) How do the apples reposuce (then selven)? } \\
\text { Transcription: } \\
\text { (4) How do the apples reproduce (themselves)? }\end{array}$ \\
\hline MAR & $\begin{array}{l}\text { 4. How do the appla reprodices? } \\
\text { Transliteration: } \\
\text { 4. How do the apples reproduce? }\end{array}$ \\
\hline MON & $\begin{array}{l}\text { 4. How do apples veproduce (Hocuselvas)? } \\
\text { Transliteration: } \\
\text { 4. How do apples reproduce (themselves)? }\end{array}$ \\
\hline
\end{tabular}

Figure I I.4 Questions written by students on their individual handouts 
"what are the parts of the growing of the apples" (excerpt 5, line 1), these are not reflected in the students' written work. This is possibly related to the precise moment when students wrote; all the students appear to finish writing during excerpt 4, with the exception of Sandra who continued writing at the end of excerpt 5.

\section{Conclusions}

In this section the main foci of the chapter are recalled and discussed. These are: how participants: (1) define the 'problems' to be solved and (2) define and make use of different resources (artefacts, concepts, etc.) in the mediational process; thereby shaping and regulating the context and course of their learning.

Firstly, it can be observed that students display an orientation to not only completing the task but also to completing it in English. This is evident, for example, in the final product of the sequence (i.e. the questions on the handout) and in the fact that the majority of talk - especially in the earlier fragments takes place in that language. It is further observed throughout the sequence how students regulate their own and each other's talk in English; drawing on multimodal (e.g. Sandra's gesturing to illustrate the verbs "reproduce", "water"; her pointing at the seed) and plurilingual (e.g. switching languages) resources, among others available to them.

The analysis demonstrates how different students focalise different leaning objects in completing the task. While Sandra primarily focuses on the concept of reproduction, some of her peers interpret the trouble as having to do with the simple translation of that concept to English. The analysis further suggests that, as the students shift their attention to the scientific object, their mobilisation of resources from languages besides English increases. Furthermore, attention to scientific content can be seen to create the sequential context for focusing on language and vice versa.

It is also remarkable that, in their written work, students display a lack of consensus and persistent doubt - displayed in their use of parentheses - in terms of the appropriate formulation of the question. Furthermore, despite students' problematisation of the adequacy of the verb "reproduce" in scientific terms, the different alternatives that emerged in the interaction are not reflected in their written work. This point is closely linked to how students made use of another available artefact - their individual handouts - during the interaction. Therefore, while the activity of writing 'appropriate questions' may have prompted students to problematise aspects of the language and the Science content, it is also the case that the students finished writing long before they culminated their negotiations. This highlights the potentially problematic nature of relying on the (written) products of intrinsically interactional learning processes as evidence, or otherwise, of the complexity of students' constructed knowledge. 


\section{References}

Alber,J.-L., \& Py, B. (1985). Interlangue et conversation exolingue. Cahiers du Departement des Langues et des Sciences du Langage 1. Lausanne: Université de Lausanne.

Barwell, R. (2003). Patterns of attention in the interaction of a primary school mathematics student with English as an additional language. Educational Studies in Mathematics, 53, 35-59.

Barwell, R. (2005). Integrating language and content: Issues from the mathematics classroom. Linguistics and Education, 16, 205-218.

Gajo, L. (2007). Linguistic knowledge and subject knowledge: How does bilingualism contribute to subject development? International Journal of Bilingual Education and Bilingualism, 10(5) 563-581.

Goodwin, C. (1994). Professional vision. American Anthropologist, 96(3), 606-633.

Goodwin, C. (1995). Seeing in depth. Social Studies of Science, 25, 237-274.

Hayashi, M. (2003). Language and the body as resources for collaborative action: A study of word searches in Japanese conversation. Research on Language and Social Interaction, 36(2), 109-141.

Lantolf, J. P., \& Thorne, S. L. (2006). Sociocultural theory and the genesis of second language development. Oxford: Oxford University Press.

Llompart, J., Masats, D., Moore, E., \& Nussbaum, L. (2020). "Mézclalo un poquito": Plurilingual practices in educational milieus. International Journal of Bilingual Education and Bilingualism, 21(1), 98-112.

Moore, E. (2014). Constructing content and language knowledge in plurilingual student teamwork: Situated and longitudinal perspectives. International Journal of Bilingual Education and Bilingualism, 17(5), 586-609.

Mori, J., \& Hayashi, M. (2006). The achievement of intersubjectivity through embodied completions: A study of interactions between first and second language speakers. Applied Linguistics, 27(2), 195-219.

Pekarek Doehler, S. (2009). Mediation revisited: The interactive organization of mediation in learning environments, Mind, Culture, and Activity, 9(1), 22-42.

Pitsch, K. (2005). Interaction, auto-organisation et pratiques d'inscription:Approximation lexicale en classes bilingues. Acquisition et interaction en langue étrangère, 22, 73-100.

Schegloff, E. A, Jefferson, G., \& Sacks, H. (1977). The preference for self-correction in the organization of repair in conversation. Language, 53, 361-382.

Seedhouse, P. (2004). The interactional architecture of the language classroom. Malden, MA: Blackwell Publishing. 
Plurilingual activities

in computer-mediated interaction 


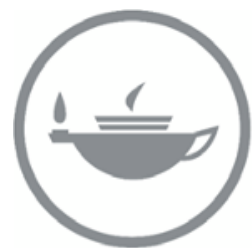

Taylor \& Francis Taylor \& Francis Group http://taylorandfrancis.com 


\title{
"Can you repeat please?" \\ Young learners' emergent awareness \\ and use of interactional repertoires \\ in a telecollaborative exchange
}

\author{
Melinda Dooly
}

\section{Introduction}

It is widely acknowledged that technology can play a key role in language education through the amplification of opportunities to use the target language with other learners or speakers outside of the classroom. However, research into the use of Computer-Mediated Communication (CMC) with young, beginner learners is far less frequent as it is often assumed that some level of language proficiency is required for effective telecollaboration. There is a need for inquiry into whether and how the technology can support the language learning process and, if affirmative, what effective teaching strategies are deployed to optimise 'learnable moments' during its use. As seen in this study, teachers can use CMC to elicit engagement, ensure repetition of formulaic language or to focus language use during technological glitches. CMC also affords ample opportunities to learn and practice mediation strategies during interactional troubles, even in young learners such as those in the study. This chapter places a detailed lens on these and similar practices, providing support for the introduction of $\mathrm{CMC}$ in early language education.

This chapter looks at the moment-to-moment verbal and embodied sequences of interaction between young language learners engaged in a CMC session. The session involvedVirtual Exchange (also known as telecollaboration) between very young learners (ages 7-8) of English as a Foreign Language (EFL). The study considers how the teacher used opportunities that emerged during an information-gap activity carried out between the geographically distanced partners to promote spontaneous moments of learning. During the online interaction, the teacher guides the learners' attention to and promotes the use of contextualised, brief and polite, exchanges in the target language. The analysis reflects how the teacher focuses the learners' attention on Turn Construction Units (TCUs; Schegloff, 2007) that constitute social basics of interactional competence in English and their production as an indicator of potential learner uptake. 


\section{Methodological framework: Approach and context}

This study applies an emic, CA approach (Masats, 2017) to data compiled during a telecollaborative project between two primary education schools. One school in Catalonia had two group-classes of 26 students (we look at a halfgroup of one of the classes) and the other was located in Austria, with a single class of 24 students. We look at four excerpts from a 12 minute, 16 second telecollaborative exchange, mediated through the digital platform Skype.

The cross-disciplinary project was carried out over the course of four months and involved learning about healthy and unhealthy habits through English. The ethnographic study was designed and carried out collaboratively (including design of teaching materials) between GREIP researchers and teachers (Nussbaum, 2017). Parental permission to record was mediated through the school administration. The young learners were first 'recruited' by 'avatar social scientists' to help them observe three cases of 'avatar tweens', all of whom had some good habits but also some rather deleterious ones as well. In groups of four, the young 'scientist helpers' watched assigned case studies of the subjects named Smelly Susan (with obvious hygiene problems), Hungry Helga (with dietary challenges) and Gameboy Gary (with a videogame addiction). The cases had slight variations in all the versions to allow for eventual comparison and completion of information gap activities that led to the exchange.

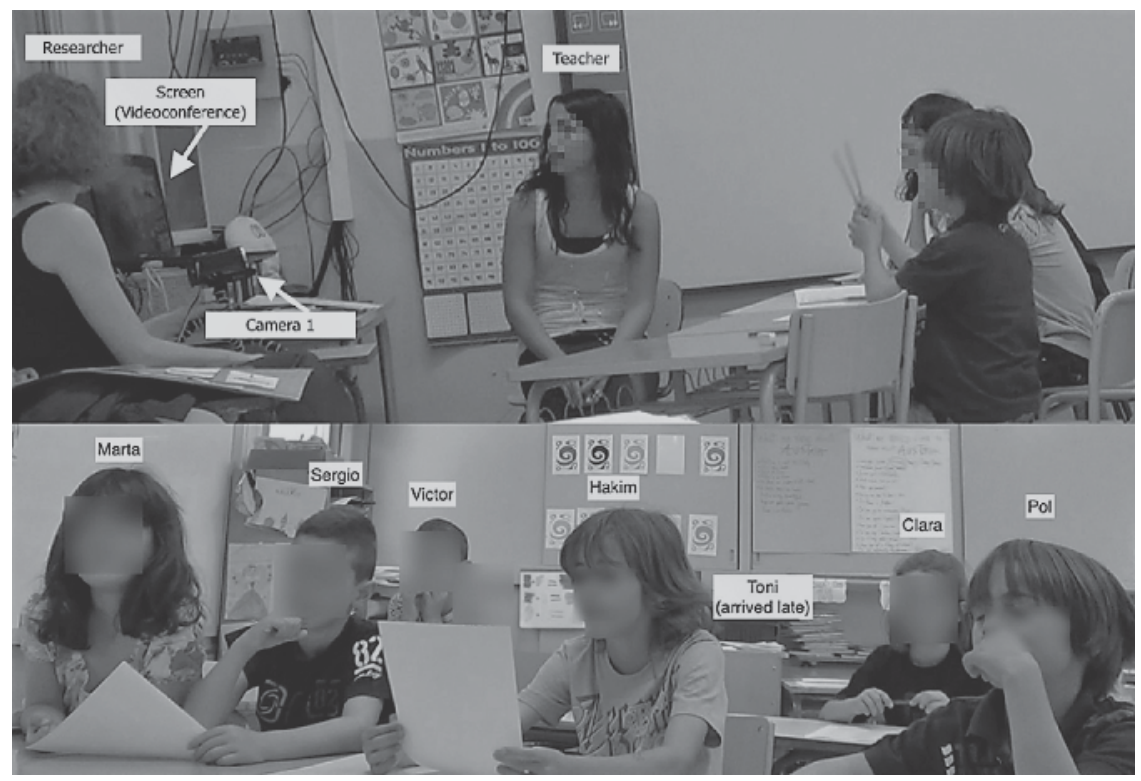

Figure I2.I Class arrangement of participants 
The excerpts analysed herein stem from one of the first telecollaborative sessions in which the young learners are involved in a comparative information exchange regarding their observations. Figure 12.1 above shows the position of the participants in relation to the computer screen where they can see their telecollaborative partners.

The focus of the analysis is on the different ways in which the young learners notice, practice and display emergent interactional competence in both the face-to-face and online interaction. We follow Hall's (2018) proposal of the use of 'interactional repertoires' (IR) in reference to the actions and semiotic resources used to display context-situated accountability in the interaction and epistemic stance of IR in the target language.

\section{Analysis and discussion}

Excerpt 1 begins at the point in which the teacher is explaining to the class the activity they will be carrying out with their telecollaborative partners. They have part of the information needed for the 'scientist helpers' and their distanced partners have complementary information regarding the case studies. The videoconference has not yet begun at the beginning of this excerpt.

Excerpt 1. 'Answer answer'. Participants in Barcelona:Teacher (TEA), researcher (RES), students in choral response (SS), other students, namely Marta (MAR), Sergio (SER), Hakim (HAK), Toni, Victor, Pol, Clara (see class configuration in Figure 12.1 above), unidentified student (??). Onscreen: Teacher in Vienna (VTEA), students in Vienna (VSS), unidentified student in Vienna (Vst).

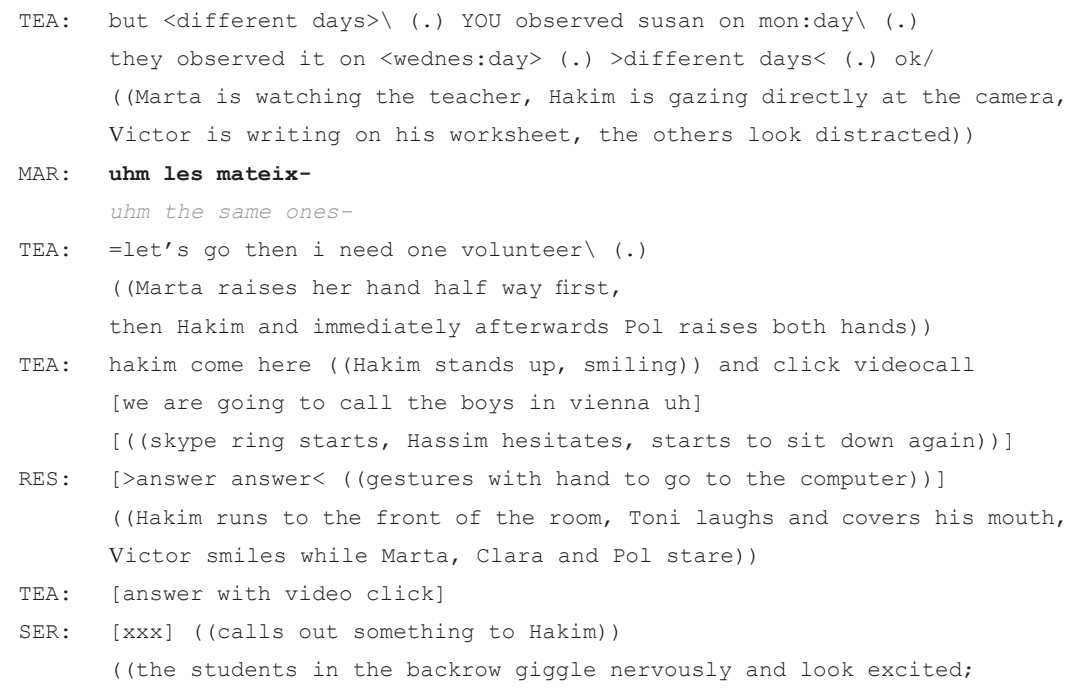




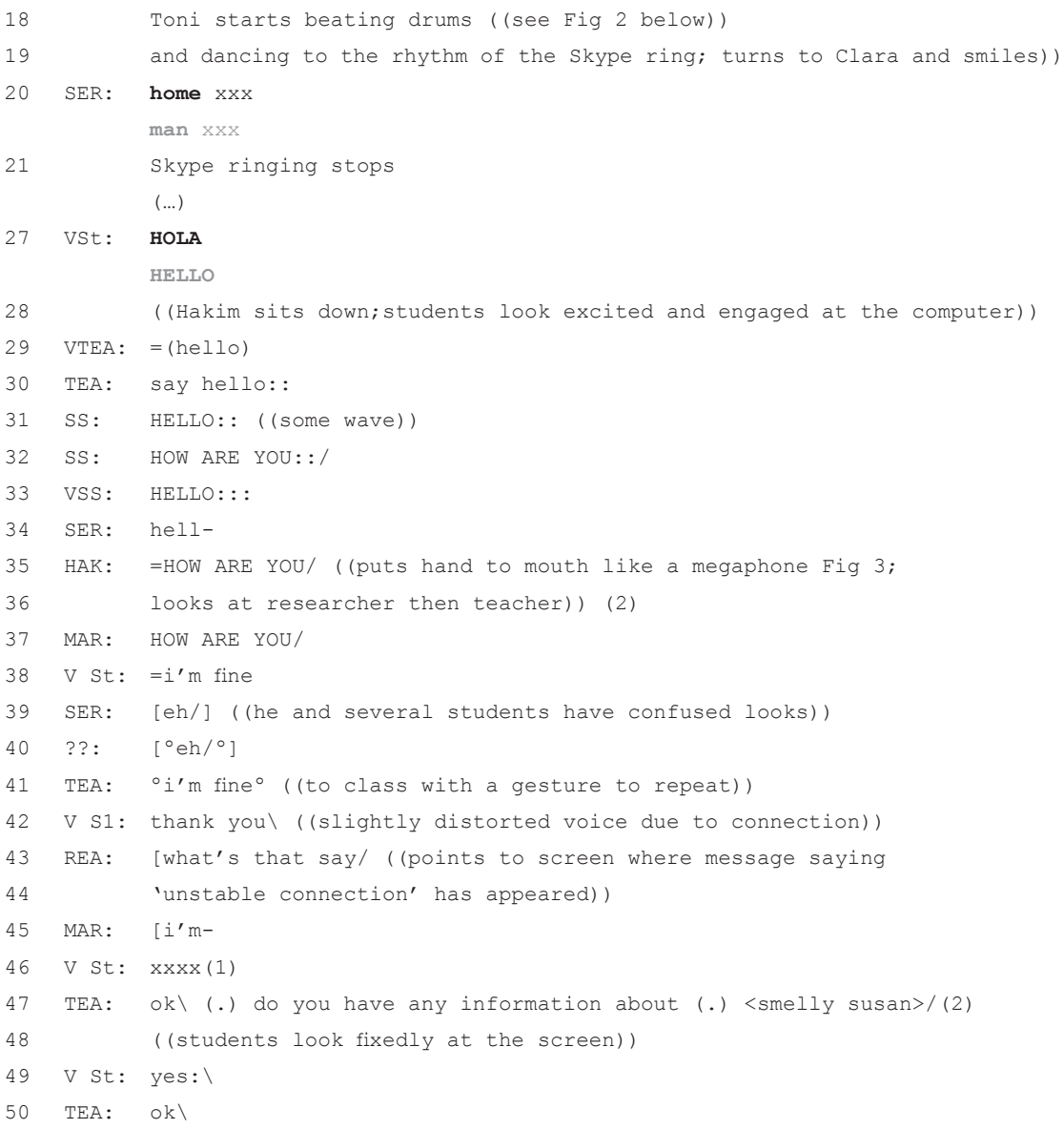

In line 1 the teacher checks comprehension with a token "ok?", which receives a partial verbal response from Marta, delivered in Catalan. However, there is an overlap between Marta and the teacher; oriented to by Marta as an interruption (she abruptly stops speaking). Switching to English in line 6, the teacher then asks for and selects a volunteer to start the videoconference; however, the distanced partners call first (line 11), which provokes an embodied hesitation from Hakim. The musical ringing noise (recognisable Skype sound) invokes a generalised excitement among the young learners, visible through their exclamations in Catalan (line 20) and embodied social interactions (drumming to the music, which can be seen as a response to the prosody of the technological modality, smiling at each other, information-seeking utterances in lines 17-19). These embodied actions are also indicative of their engagement in the activity. This continues to be displayed throughout the excerpt (e.g. line 48 ) as seen in Figures 12.2 and 12.3 below. 


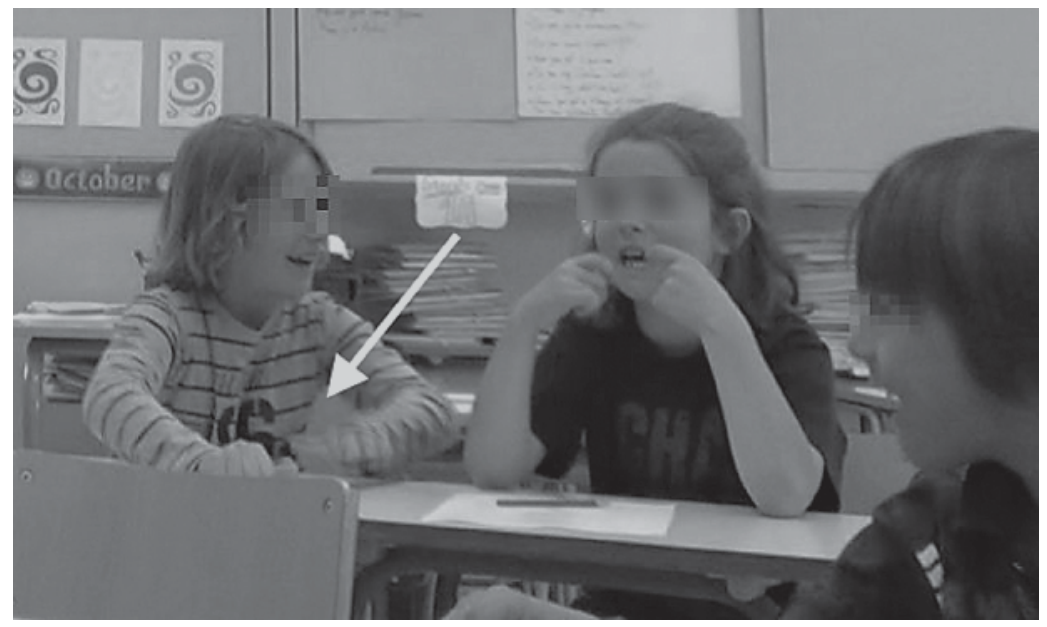

Figure 12.2 Drumming to the ring

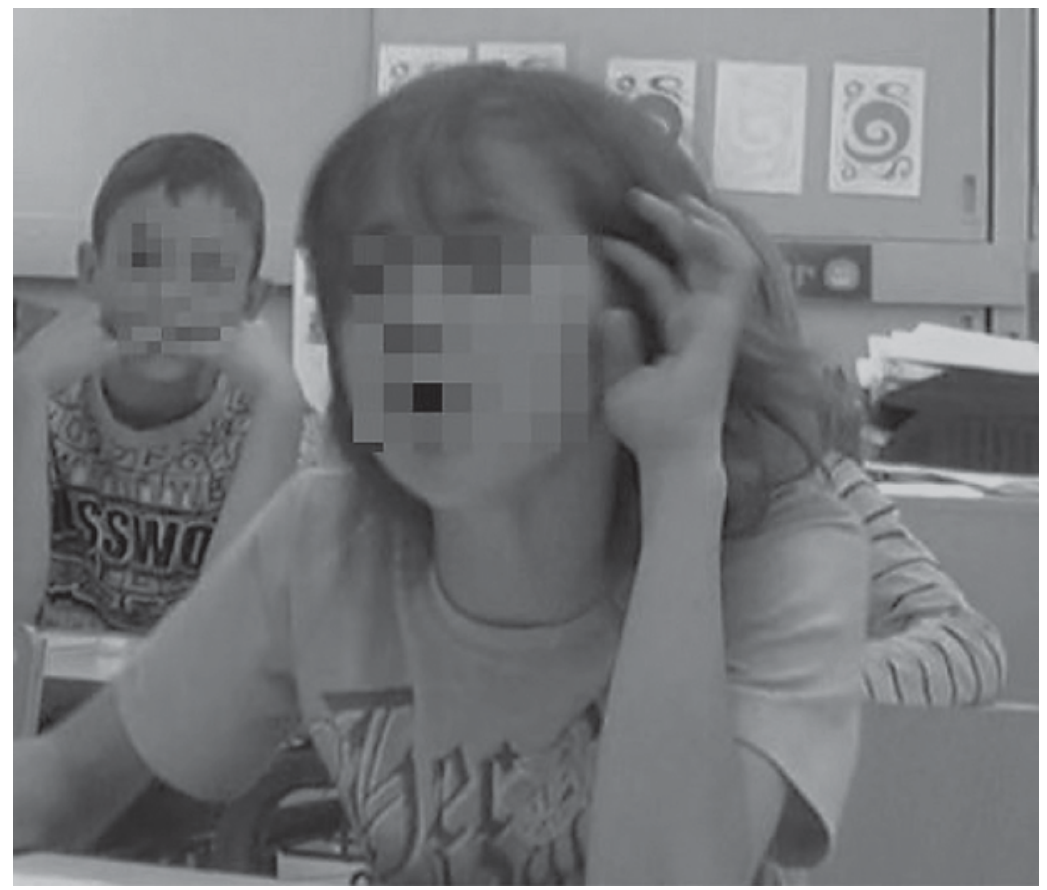

Figure 12.3 Hand megaphone: How are you? 
Interestingly, the distanced partner (V St) initiates the first turn of the videoconference in the L1 of her partners (Catalan or Spanish - the greeting is the same in both languages) in line 27; however, the videoconference teacher immediately follows up her greeting with another one in English. The teacher in the classroom elicits a choral response from the class in line 30, positioning the young learners in an epistemic stance of 'knowing' $(\mathrm{K}+)$. That is, the teacher elicits a display of their knowledge regarding the appropriate deployment of IR for initial greetings in English. In line 31, the students not only verbally respond correctly, their embodied social interactions (e.g. waving) indicate that they are aware of the meaning of the exchange.

The students themselves self-initiate the first part of the next adjacency pair in the TCU in line 32 with "how are you?" providing further evidence of their $\mathrm{K}+$ status of the IR required for an international videoconferencing context. In line 34 , Sergio initiates a repetition of the first adjacency pair, in response to the videoconference partners greeting; however, there is an overlap with Hakim, in line 35, who loudly (and with exaggerated embodiment) repeats the previous salutation of the TCU.

After a two-second pause, perhaps due to the lag in the videoconference communication or prompted by Hakim's behaviour, Marta repeats the second part of the greeting (repetition of "how are you?" in line 37). This prompts the completion of the TCU from the telecollaborative partners ("I'm fine", line 38), which subsequently leads to a downgrading of epistemic status to K- of several of the students (Sert, 2015), displayed through parallel utterances of "eh" in lines 39 and 40 and embodied responses of confusion.

The downgrading to $\mathrm{K}$ - evokes an embedded and embodied repair by the teacher in line 41 in which she models and then elicits a choral response for the correct utterance ("I'm fine"); however, before the students have time to repeat the utterance, their telecollaborative partners provide a post-expansion to the adjacency pair, saying "thank you" in line 42 .

In line 45, Marta self-allocates the turn to reply to her partners with "I'm" (perhaps due to a misunderstanding of the previous part of the turn in line 42, which was quite distorted) but there is an overlap by the researcher (line 43), which is oriented to as an interruption by Marta so she does not complete her utterance. Further interactional trouble - caused by technology glitches in line 46 - leads to a transition relevant place which the teacher appropriates for a new topic bid, leading the class into the task of information exchange, "ok, do you have any information about Smelly Susan?"

In excerpt 2 the two partner classes are exchanging information regarding the information they have gathered while watching their small group case studies. The distanced partners go first, listing the healthy habits they have noted while observing the interviews with Smelly Susan. 
Excerpt 2. Can you repeat please? Participants in Barcelona: Teacher (TEA), researcher (RES), students in choral response (SS), other students, namely Clara (CLA) Marta (MAR), Sergio (SER), Hakim (HAK),Victor, Pol, Clara (see class configuration in figure 1). Onscreen: Teacher in Vienna (VTEA), students in Vienna (VSS), student in Vienna (VS1)

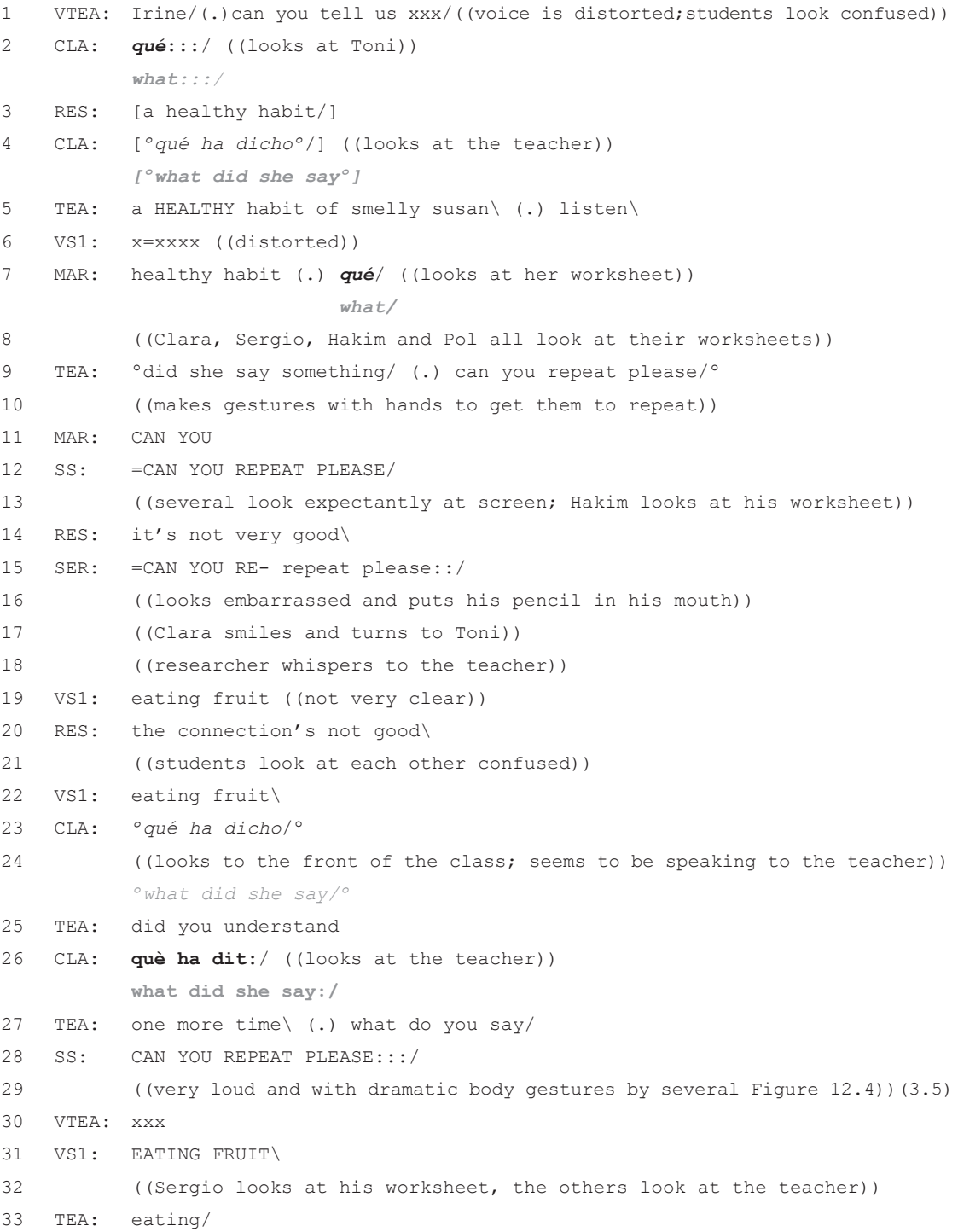




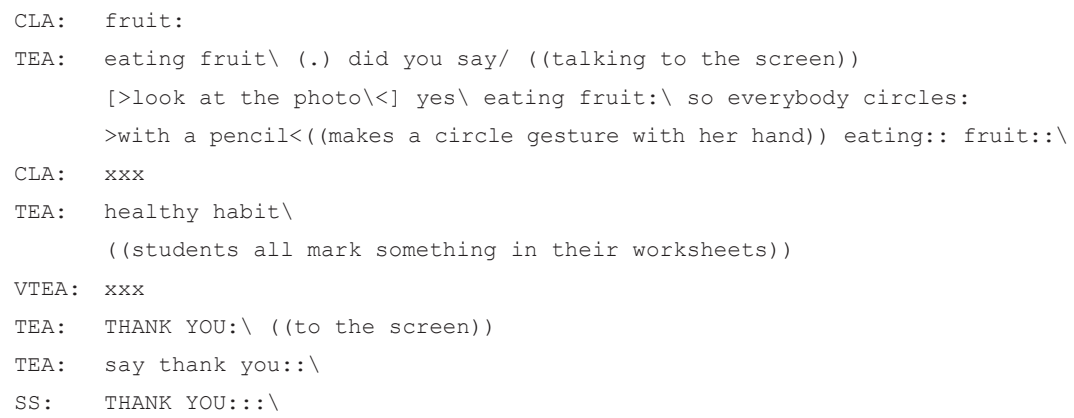

The excerpt begins with several incidences of "classroom interactional trouble" (Sert, 2015: 58). In the sequence of events, the communication technology impedes the students' comprehension (time lags, distorted voices) and the young learners express their confusion through both embodied and verbal actions (lines 1-7). In line 9, the teacher converts this interactional trouble into a 'spontaneous learnable' (Majlesi and Broth, 2012), by modelling the appropriate utterance to initiate an other-repair clarification request "can you repeat please?". This is accompanied by an embodied elicitation (gesturing) to repeat the phrase. In line 11, Marta begins an unsuccessful self-allocated turn, which she abruptly stops when she realises she is alone; however, the other students immediately chime in with the choral repetition in latched speech in line 12 . The lack of response from the videoconference partners elicits a repetition of the utterance from Sergio. This utterance includes a self-repair, "CAN YOU RE- repeat please" (line 15).

The unrelenting interactional trouble contributes to Clara's increasing frustration, evident in her continued requests for clarification, first in a short token utterance ("what?" to her classmate, Toni, line 2), followed by ("what did she say?" repeated twice in Spanish in lines 4 and 23 and finally in Catalan in line 25), the last requests directed at the teacher. Once more, in line 26, the unfolding sequence affords the teacher a second opportunity to elicit a demonstration of the learners' $\mathrm{K}+$ regarding the interactional moment by asking "what do you say?". This elicits a correct choral response from the students, "can you repeat please?" very loudly, allowing the learners to display both verbally and through embodiment their 'knowing'; exemplified through the volume of their utterance and the dramatic gestures employed.

The students' exaggerated response is mirrored by their telecollaborative partners, who repeat their answer, also very loudly. The teacher then deploys a 'designedly incomplete utterance' (Margutti, 2010) to check comprehension of the telecollaborative partner's response (line 33, "eating ...") which is completed by Clara in the next line ("fruit"). Interestingly, it has been Clara who has demanded the most clarifications and repair work during the entire excerpt. Finally, at the end of the excerpt, the teacher provides another spontaneous 


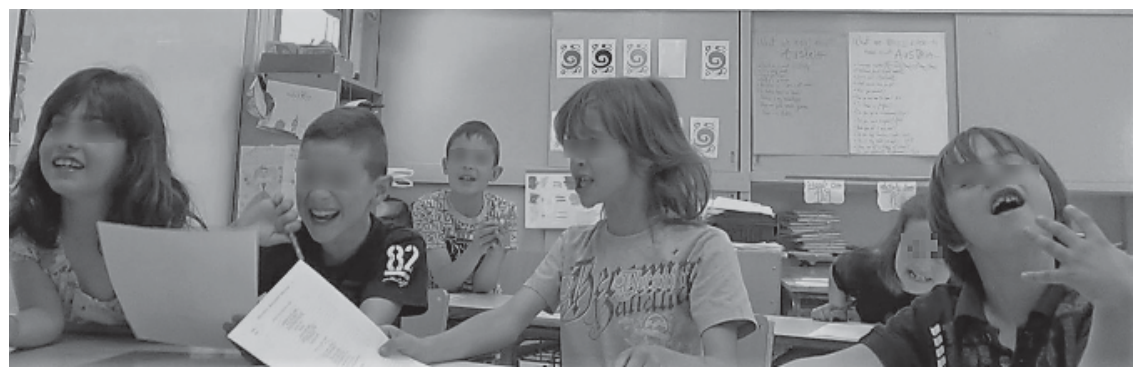

Figure 12.4 'Repeat PLEASE!'

learnable by first demonstrating and then asking for repetition of the interactional resource of a sequence-closing third part of the information-exchange TCU: the finalisation of the turn with 'thank you' (lines 42-44).

As the exchange continues, we begin to see several incidences of uptake by the learners of the teachers' prior repairs, embedded modelling and use of known-information hints in their deployment of interactional resources for 'polite' repair work and expanded TCUs in the target language of English.

Excerpt 3. Bup bup. Participants in Barcelona: Teacher (TEA), students in choral response (SS), unidentified student (??), other students, namely Clara (CLA), Hakim (HAK), Pol (POL), Sergio (SER). Onscreen: Teacher in Vienna (V TEA), student in Vienna (V S1)

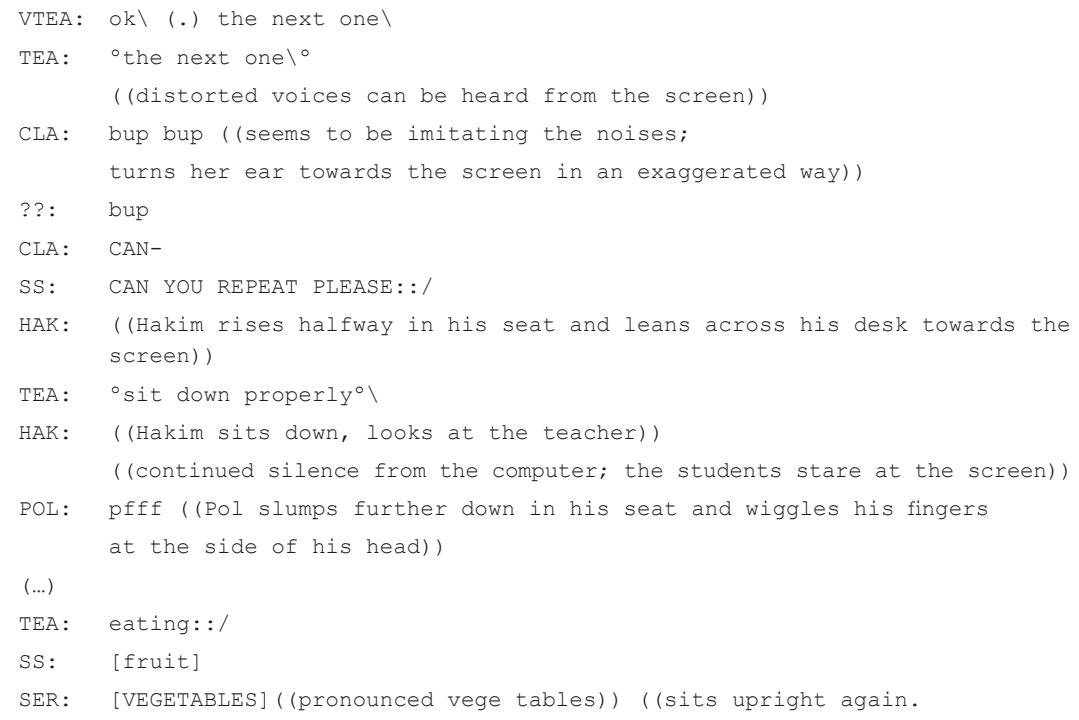




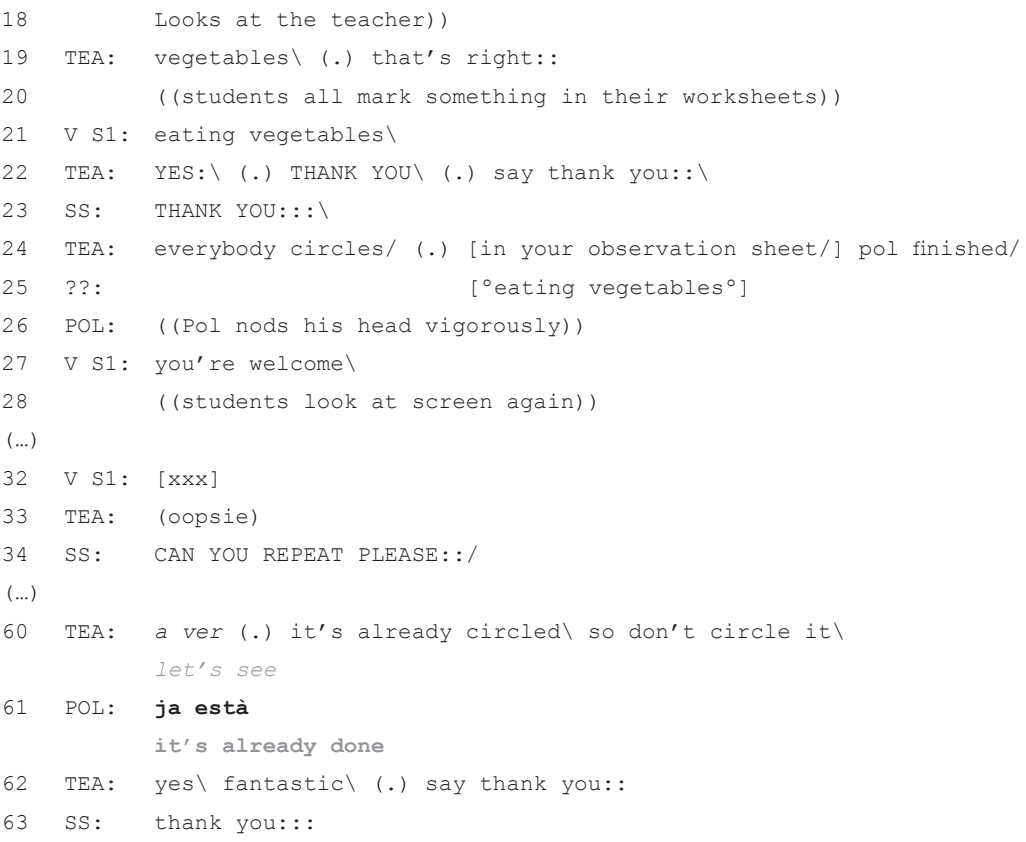

At the beginning of the excerpt, the technological glitches of the communication channel have once more created interactional trouble (lines 1-6). In line 7, Clara self-allocates a turn in which she elicits an other-initiated repair and begins the utterance 'can'. This prompts the rest of the class to join in with the recently presented repair work utterance, "can you repeat please?" In this excerpt, different from the previous ones, the repair work is not elicited by the teacher; the students self-allocate the turn and correctly select the IR needed to solicit repetition of the answer from their telecollaborative partners. A similar TCU takes place a few lines further on (lines 32-34), providing further evidence of uptake on behalf of the students. However, the second embedded spontaneous learnable (the use of a third position post-expansion action of 'thank you') does not seem to be successfully assimilated at this point as they must be reminded twice to use the resource (lines 22 and 62) nor do they initiate the third position post-expansion on their own.

Line 60 presents an interesting case of plurilingual use, initiated by the teacher, who had, till now, predominantly started all her turns in English. In this instance, however, she initiates the instructional turn in Spanish but self-repairs, switching to English in the middle of the turn, signalling to the students the preferred language choice for the class. Pol replies to the second part of her utterance, oriented to the instructions delivered and clearly indicating his comprehension of the directives given in English. However, his answer, in alignment with the first part of line 60, is delivered in Spanish. This TCU is closed by the 
teacher in yet another language switch (back to English in line 62: "yes, fantastic") before opening another TCU in English "say thank you".

In excerpt 4, captured at a later point in which the young learners are conveying their observations about Smelly Susan to their telecollaborative partners, there now appears to be uptake of the previous spontaneous learnable regarding the post-expansion 'thank you'.

Excerpt 4. Drinking lots of water. Participants:Teacher, videocall teacher, Marta, Videocall student, Hakim, Pol, Carla, Toni

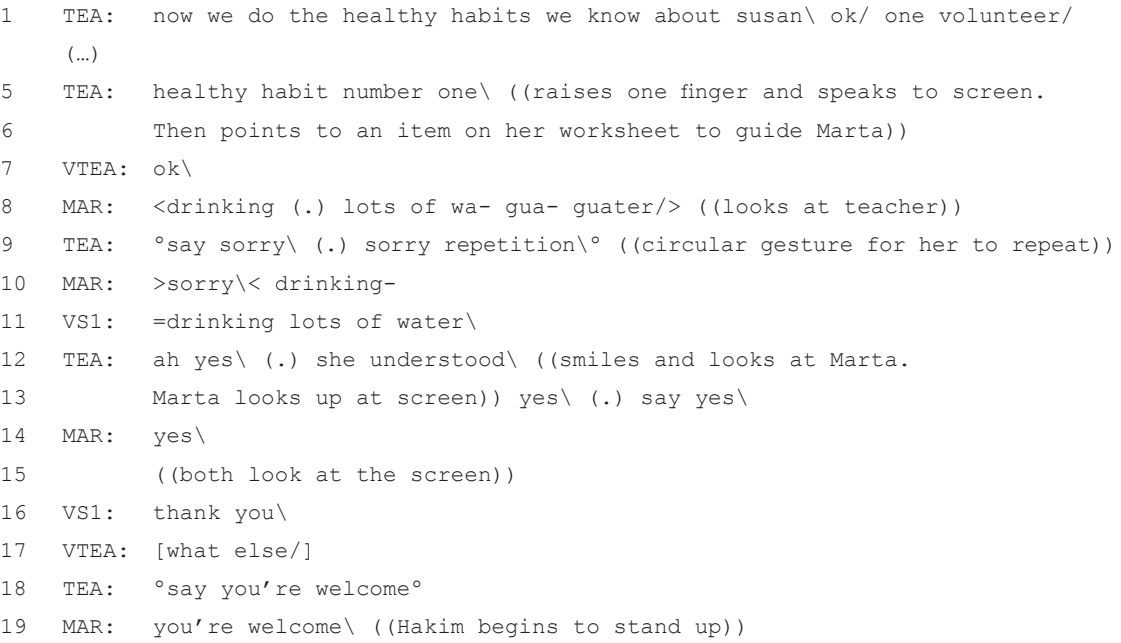

In line 8, Marta has difficulties with the pronunciation of a target word (water) and attempts to self-repair several times. The complicit looks between Marta and the teacher indicate awareness that this is causing delays in the progressivity of the interaction. The teacher again seizes the opportunity for a spontaneous learnable by offering an alternative repair sequence: "say sorry". Marta successfully begins to self-repair in line 10 but this is overlapped by the student on the conference call who has understood Marta's previous turn without need for further clarification. To complete the TCU, the telecollaborative partner provides the post-expansion third position "thank you" so the teacher proposes yet another adjacency pairing: "say you're welcome", which Marta repeats in line 19.

\section{Conclusion}

This study corroborates other studies that demonstrate how learners can develop competence in the target language through mobilisation of plurilingual and plurimodal resources (Llompart et al, 2020). Through a close look at the 
moment by moment unfolding of the sequential events during an international online exchange between two primary education foreign language classes, we have identified moments of both $\mathrm{K}+$ and $\mathrm{K}$ - stance regarding awareness and ability to deploy plurimodal, plurilingual interactional resources appropriate for the situated practices of beginning learners of the target language. The teacher carefully guides the learners through opportunities that emerge as the participants engage in 'authentic' moments of social interaction, mediated through communication technology. The IR deployed range from token repair responses such as "sorry" to post-expansion turn adjacencies of successful information exchange ("thank you"), displaying the young learners' emergent accountability for the context-sensitive employment of appropriate linguistic and embodied interactional resources.

\section{Acknowledgements}

This chapter stems from data collected in a project led by Dr. Dolors Masats. Her cooperation and the collaboration with the two teachers involved, Maria Mont and Manuela Ebner, as well as my colleague Dr. Randall Sadler, were essential to the success of the project. And of course my deep appreciation to the (now grown) students included here. Their enthusiasm and love for learning inspire me even now, years after visiting their classroom.

\section{References}

Hall, J. K. (2018). From L2 interactional competence to L2 interactional repertoires: Reconceptualising the objects of L2 learning. Classroom Discourse, 9(1), 25-39. https://doi.org/10.1080/19463014.2018.1433050.

Llompart, J., Masats, D., Moore, E., \& Nussbaum, L. (2020). 'Mézclalo un poquito': plurilingual practices in multilingual educational milieus. International Journal of Bilingual Education and Bilingualism, 23 (1), 98-112.https://doi.org/10.1080/ 13670050.2019.1598934.

Majlesi, A. R., \& Broth, M. (2012). Emergent learnables in second language classroom interaction. Learning, Culture and Social Interaction, 1(3-4), 193-207. https://doi.org/ 10.1016/j.lcsi.2012.08.004.

Margutti, P. (2010). On designedly incomplete utterances: What counts as learning for teachers and students in primary classroom interaction. Research on Language and Social Interaction, 43(4), 315-345. https://doi.org/10.1080/08351813.2010.497629.

Masats, D. (2017). Conversation analysis at the service of research in the field of second language acquisition (CA-for-SLA). In E. Moore \& M. Dooly (Eds), Qualitative approaches to research on plurilingual education / Enfocaments qualitatius per a la recerca en educació plurilingüe / Enfoques cualitativos para la investigación en educación plurilingüe (pp. 321-347). Dublin/Voillans: Research-publishing.net. DOI: https://doi.org/ 10.14705/rpnet.2017.emmd2016.633. 
Nussbaum, L. (2017). Doing research with teachers. In E. Moore \& M. Dooly (Eds), Qualitative approaches to research on plurilingual education / Enfocaments qualitatius per a la recerca en educació plurilingüe / Enfoques cualitativos para la investigación en educación plurilingüe (pp. 46-67). Dublin/Voillans: Research-publishing.net. https://doi.org/ 10.14705/rpnet.2017.emmd2016.621.

Schegloff, E. A. (2007). Sequence organization in interaction. Cambridge: Cambridge University Press.

Sert, O. (2015). Social interaction and L2 classroom discourse. Edinburgh:Edinburgh University Press. 


\section{"What do you like about Spain?" Building understandings of people and places in interaction mediated by plurilingual and digital resources}

\section{Emilee Moore and Claudia Vallejo}

\section{Introduction}

In today's highly diverse and interconnected societies, youth's lives, and their encounters with close or distant people, languages and cultures, are significantly and regularly shaped by multimodal, digital communication technologies. These do not just mediate but actually model and transform their social interactions and shape their expectations and understandings of self, others and 'the world' at many scales and dimensions. As sociolinguists and educators, approaching and illuminating the complexity of how young people navigate the constellations of information, social relations, resources and possibilities afforded by the ensemble of social diversity and digital communications seems like a necessary action - one that should be developed from an action/activist research stance. This approach can provide researchers, educators and youth with spaces and opportunities to critically and collaboratively reflect upon their preconceptions and stereotypical expectations of themselves and others and how these transpire into specific interactions, as a first step to deconstruct or transform worldviews and dispositions.

This chapter focuses on a sequence of interaction, recorded using ethnographic methods, involving young people with different linguistic and cultural repertoires taking part in an after-school digital storytelling program. We are interested in how participants give meaning to the 'context' of their encounter and, in particular, how they identify themselves, each other and places. We also discuss the resources they mobilise in managing interaction. The main theoretical tools discussed in the next section are membership categorisation and transidiomatic practices. The research project that yielded the data presented and the methodology employed are then introduced, followed by the data analysis and conclusions.

\section{Producing understandings of people and places}

This chapter is primarily centred on the understandings that participants build of people and places. In the Social Sciences, 'context' is often used vaguely 
to relate a particular phenomenon (e.g. an interactional encounter) to factors considered to be of a higher order (e.g. the 'who', 'when', 'where', 'why'). Despite the lack of a common definition as to what is implied when speaking about context, Goodwin and Duranti (1992), following Goffman (1974), argue that there is general consensus that context is something framing communicative events and offering resources for their interpretation.

Schegloff (1992) describes two general trends in how context is brought into research in the Social Sciences. In the first, what is of primary interest is the particular event, behaviour or statement that is framed by a context. In such studies, analysts' own understandings of different elements assumed to make up the context are invoked. This is the approach that Cameron (1990) argues strongly against in her call for a demythologised sociolinguistics. She succinctly critiques much research - especially quantitative - in this tradition for its straightforward assumption that something called 'context' somehow exists before something called 'language'. Cameron deconstructs what she terms the 'correlational fallacy', whereby analysts make use of their understanding of gender, race, class, etc. to elucidate human language behaviour, without recognising that those same elements are themselves in need of explanation. Therefore, she claims, the explanation does not in fact explain anything!

This leads to the second approach pointed to by Schegloff (1992). This is the perspective taken, in particular, in traditions such as Interactional Sociolinguistics, Linguistic Anthropology, Linguistic Ethnography, Ethnomethodology and Conversation Analysis - all disciplines influencing the approach taken in this chapter. Research in these traditions tends to be interested in advancing our very understanding of context; thus, context becomes an object of, not just a factor in, analyses. Context is conceived as "a socially constituted, interactively sustained, time-bound phenomenon" (Goodwin and Duranti, 1992: 6). As ten Have (2002) writes, social facts are produced through participants' practical activities, and the task of the researcher is to demonstrate the procedures through which they are accomplished. From this perspective, participants not only orient to the different phenomena that constitute context in the course of their actions; they also take part in the situated production of those phenomena.

One way that people produce context is through a procedure known as membership categorisation (e.g. Sacks, 1974). The largest body of work on membership categorisation has been concerned with identities (e.g. Antaki and Widdicombe, 1998). From the perspective of mythologised sociolinguistics, identity has been conceived of in terms of pre-existing characteristics of people that determine their language-related behaviour. From a radically different stance, membership categorisation allows identity to be conceptualised as a social fact produced in interaction.

Central to the membership categorisation apparatus is the Membership Categorisation Device (MCD), which Sacks (1974) defined as a collection of membership categories plus rules of application. We begin with the first part of the MCD apparatus, being collections of membership categories. For example, 
'classroom' is one collection, which includes categories such as 'teacher' and 'student'. Related to such categories are category-bound activities and predicates, or "motives, rights, entitlements, obligations, knowledge, attributes and competencies" (Psathas, 1999: 144). Thus, the category 'teacher' is linked to the category-bound activity of 'teaching' and to certain normative expectations in terms of competences, knowledge, rights and obligations.

As for the second part of the MCD apparatus - rules of application - Sacks (1974) outlined two. The first is the economy rule, according to which a single category term from a MCD does adequate reference to a person. So, the single category 'teacher' would be enough to identify a person at any given time. The second rule - the consistency rule - states that if several people are being categorised, and the first is categorised using a category from a particular collection, it would be relevant to use that same collection to categorise the remaining people. So, once a 'teacher' has been identified, the other members present could be categorised as 'students'.

In the data studied in this chapter, participants' membership categorisation work is mediated by plurilingual and digital resources. A main feature of the data we present is the use of a laptop computer and the Google Translate tool and the young people's familiarity with Asian pop cultures. We refer to the participants' transidiomatic practices to describe the "comingling of localised, multilingual interactions and technologically mediated, digitalised communication" (Jacquemet, 2016: 8). The notion of transidiomatic practices emerged from Jacquemet's (2005) research on sociolinguistic superdiversity, migration and asylum processes, and complements other concepts that similarly extend Gumperz's (1964) approach to repertoire (e.g. plurilingualism, translanguaging (Vallejo and Dooly, 2020) or transmodalities (Hawkins, 2018)). While our research is located in a very different setting from Jacquemet's, we are inspired by his research showing how digital communication technologies (e.g. Skype, Facebook, Google) in contexts of linguistic and cultural (super)diversity are much more than facilitators of interaction; rather, they transform interactions and access to knowledge. Jacquemet (2016: 4) describes how they "alter the very nature of this interactivity, confronting people with expanded rules and resources for the construction of social identity and transforming people's sense of place, cultural belonging, and social relations".

We now turn to the methodology employed in the collection and analysis of the data presented.

\section{Methodology}

This chapter presents one aspect of a collaborative, intersectoral educational initiative - referred to as 'Let's Go!' - undertaken in a socio-economically disadvantaged municipality in the Barcelona Metropolitan Area. The initiative was aimed at boosting the English language competences of youth in the municipality. The specific work presented here was carried out as part of 
the funded research project entitled 'Inclusive epistemologies and practices of out-of-school English learning (IEP!)', an ethnographically informed action/activist research project (Vianna and Stetsenko, 2014; Moore and Vallejo, 2018) which, among other objectives, aimed to increase youths' access to quality non-formal opportunities for learning English. One of the after-school opportunities implemented as part of this research was a digital storytelling project, part of the 'Global StoryBridges' network, linking the young people with youth in other parts of the world, in order to promote their English language learning, digital literacies and critical cosmopolitanism (Hawkins, 2014). Local groups met and collectively produced video stories in English (the lingua franca) that represented different aspects of their lives, for audiences of youth at the other sites. These videos were shared on the project's web-based platform. Alongside this digital storytelling process, different overlapping and complementary activities took place in the project sessions, including those related to building and sustaining relationships among participants, different off-task activities, etc.

The analysis presented here is of a video-recorded interaction, and we account for multimodal interactional features as well as human and non-human actors (i.e. youth and adult participants, a laptop computer with Google Translate). The names of people used in this chapter are pseudonyms, with the exception of the adult facilitators - two of whom are authors - who agree to their real names being used. The adults facilitating the session - Claudia, Emilee and Miaomiao - were guiding the youth to think of and type up a list of places that could be filmed for future digital stories. Miaomiao was a PhD student from China who participated as facilitator and researcher in the sessions. Her presence was received with great enthusiasm by the young participants, who were highly engaged with Asian pop cultures. Her participation regularly prompted questions from the young people about her interests, background and experiences, including the question that initiates the interactional sequence studied in this chapter: "What do you like about Spain?"

\section{What do you like about Spain?}

Here we focus on: (1) how participants give meaning to the 'context' of their encounter, and in particular how they identify themselves, each other and places; (2) the communicative resources they mobilise in managing their interaction, drawing on the theoretical tools introduced in the previous section of this chapter. Prior to the excerpt presented, the young people - Nanyamka and Naiara in particular - had established an interactional dynamic in which they typed comments or questions into the Google Translate tool in Spanish and/ or English and then had Google Translate read the translation in Chinese aloud for Miaomiao to react. This was novel in the session, as interaction between the youth and Miaomiao usually took place in English, with stronger users of English - mainly Nanyamka (who was schooled in English as a child in Ghana), 
Claudia or Emilee - providing support for those less proficient. Miaomiao claimed to know little Spanish and no Catalan.

In excerpt 1, Nanyamka and Naiara wish to ask Miaomiao what she likes about Spain. Naiara takes the lead immediately prior to the fragment in typing a question to be translated from Spanish to Simplified Chinese (as the languages are named in Google Translate). There is confusion and several minutes of problem-solving as the laptop keyboard is a US English one and does not have the 'ñ' needed to write "España", which we have not included for the sake of conciseness. The excerpt thus begins with Nanyamka playing the version of the question translated by Google Translate into Chinese for Miaomiao. In line 4, Miaomiao tells the young people what the Chinese version of the question means in English, which is followed by laughter from Nanyamka and Naiara. Several of the questions and comments translated previously in the session had been similarly distorted by Google Translate, leading to corrections and explanations by Miaomiao and scolding of the computer by the young people (as in line 9 of this excerpt), who nevertheless continue to use this resource in their interaction with Miaomiao.

Excerpt 1. Participants: youth participants, namely, Nanyamka (NAN), Naiara (NAN), Sara (SAR), Julian (JUL); facilitators and researchers, namely, Emilee (EMI), Claudia (CLA) and facilitator/PhD student from China, Miaomiao (MIA); laptop computer (COM) with the Google Translate tool

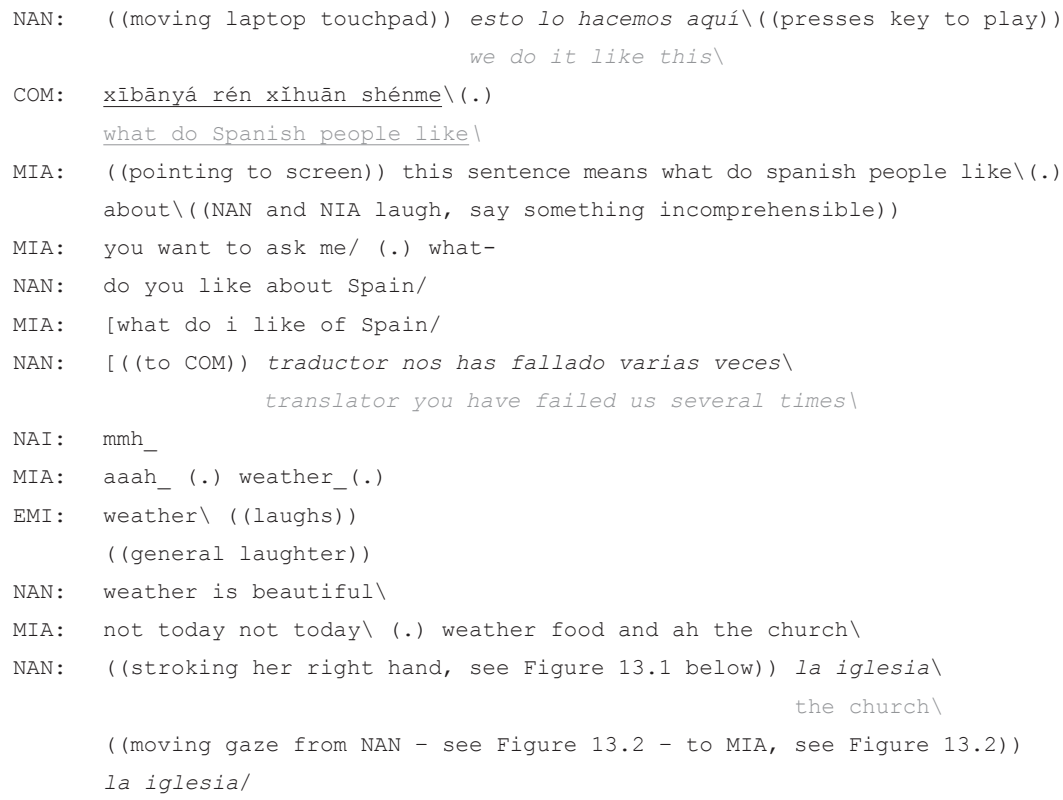


( (NAN and SAR make eye contact - NAN seems unenthusiastic and SAR smiles confused, see Figure 13.3 below))

NAN: ((to MIA)) church right/

MIA: yes church $\backslash$

NAN: ((to NAI)) lo que escuchas $[$ iglesia what you hear \ [church $\backslash$

\section{CLA:}

NAI: why/

[ask her Naiara \(.) ask her $\backslash$ (.) why_

SAR: ((laughs embarrassed))

MIA: why/

NAI: why/

JUL: te sorprende/

does it surprise you/

NAI: ((looking at MIA waiting for answer, see Figure 13.3 below)) nol

MIA: because is beautiful $\backslash($.$) the weather's beautiful \backslash$

NAN: but here or [in Barcelona/

MIA: $\quad[$ eh-

NAI: [you are (.) christian/ or- ((looks to NAN for assistance,Figure 13.4))

MIA: both\(.) christian/

NAN: are you christian/ or-

MIA: no I'm not christian but is beautiful is beautiful\

NAN: ella creo que es budal

I think she is Buddhal

SAR: but in_(.) in china/ [you have xxx/ (.) eh-

NAI :

[y por qué va a ir a la iglesial

[and why is she going to go to church/

NAN : $[y /$

and/

NAI: [la iglesia es de dios $\backslash$

[the church is of Godl

SAR: [cómo se dice iglesial

[how do you say church/

NAN: [pero iglesia no es para los-

[but church is not for the-

CLA: church $\backslash$

SAR: church/

NAN: [la iglesia no es para los budos $\backslash$

[church is not for the Buddhas $\backslash$

MIA: [oh no we have no church $\backslash$ (.) we only have temples \

NAI: Ios bud/- ya por eso pero los- pero le gusta-

the Budd/- yeah that's why but the- but she likes it-

NAN: dice que le gusta porque es bonito y que allí-

she says she likes it because it's beautiful and that there-

SAR: y que allí no hay iglesia

and that there is no church therel 


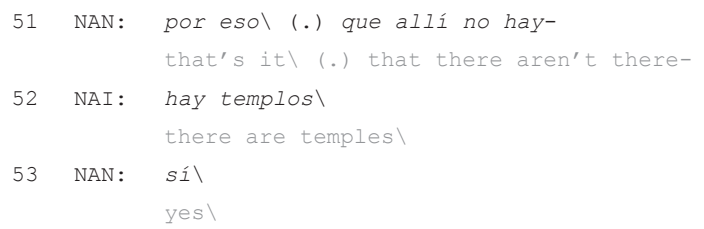

At the beginning of the excerpt (line 5), Miaomiao requests clarification about what Naiara and Nanyamka actually want to ask her. In response, Nanyamka asks Miaomiao the question in English directly (line 6), and then reprimands the computer (line 8). This direct addressing of the digital artefact frames the laptop's status as an active and accountable participant in the interaction - as animator (Goffman, 1981) and recapitulator (Wadensjö, 1998) of the young people's utterances. The question itself ("what do you like about Spain?") builds on a specific collection of membership categories - Spain - as a shared and understandable scalar sign (Blommaert, Westinen, and Leppänen, 2015) upon which to build the interaction. This 'benchmark' scalar reference (Blommaert, Westinen, and Leppänen, 2015) varies and requires clarification from some participants as the sequence evolves, as we will see later on in this analysis. Mobilising the reference to Spain makes membership categories such as 'Spanish people' and 'foreigners' (or 'Chinese people') relevant to the interaction, together with different stereotypes regarding the activities and predicates associated with them.

Miaomiao's answers to the question ("weather", "food" and "the church", lines 10 and 14) raise a series of reactions that are telling of alignments and misalignments between the young participants' categorisation of her as a Chinese person in Spain, their normative expectations of her and her listed preferences. On one hand, Miaomiao's reference to the weather prompts general laughter as, paradoxically, it was raining heavily that day. This laughter, along with Nanyamka's alignment ("weather is beautiful", line 13) and Miaomiao's later clarification ("not today not today", line 14) bridges the apparent gap between Miaomiao's fondness for Spanish weather and the current reality in a way that is not disruptive. The second of Mioamiao's favourite features of Spain, food, does not seem to incite any reaction, probably as it meets the group's category-bound expectations about things that foreigners like about Spain. However, her third preference, the church, leads to quite a different reaction from the young participants, as expressed both verbally and through gesture and gaze. In line 15, and after Miaomiao lists her three preferences, Nanyamka takes on the role of interpreter but translates only this last response to Spanish for her peers ("la iglesia"), with falling intonation and an aerial stroke of her right hand (see Figure 13.1). She thereby draws attention to and shows a lack of keenness for Miaomiao's choice. Naiara's reaction, opening her eyes wide and turning her gaze from Nanyamka to Miaomiao (Figure 13.2), to then request Nanyamka's confirmation by repeating the same word in Spanish with rising intonation (lines 16-17), shows her own bewilderment. Meanwhile, Nanyamka and Sara (another one of the young participants) make eye contact and exchange serious and confused facial expressions (Figure 13.2). 


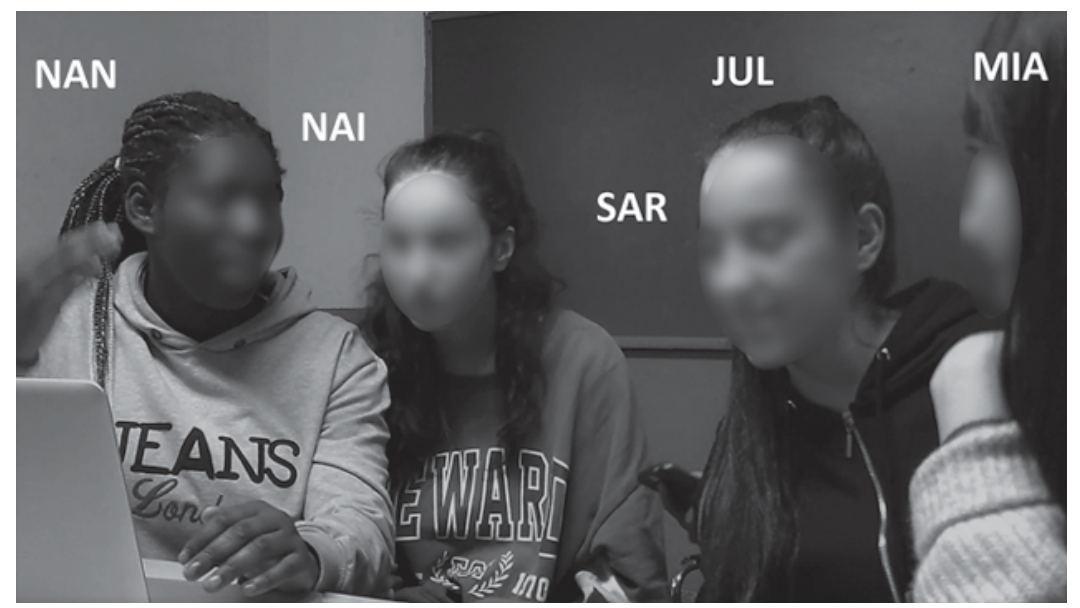

Figure 13.I Screenshot from line 15

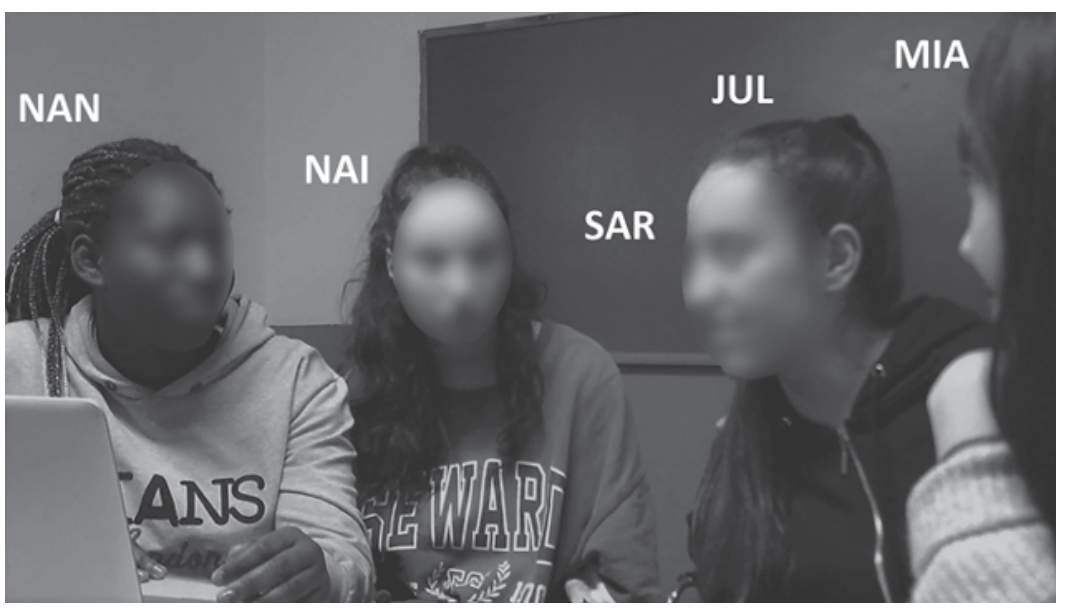

Figure 13.2 Screenshot from line 16

In line 20, Nanyamka continues in the role of interpreter, translating Naiara's request for confirmation into English for Miaomiao ("church right?"). Miaomiao, who seems quite unaware of the young people's surprise, confirms ("yes church", line 21), and then Nanyamka, switching into Spanish, ratifies Naiara's understanding with a "lo que escuchas, iglesia" ("what you hear, church") in line 22. In line 23, acknowledging the young girls' puzzlement, Claudia, another one of the adult facilitators, prompts Naiara to ask Miaomiao 


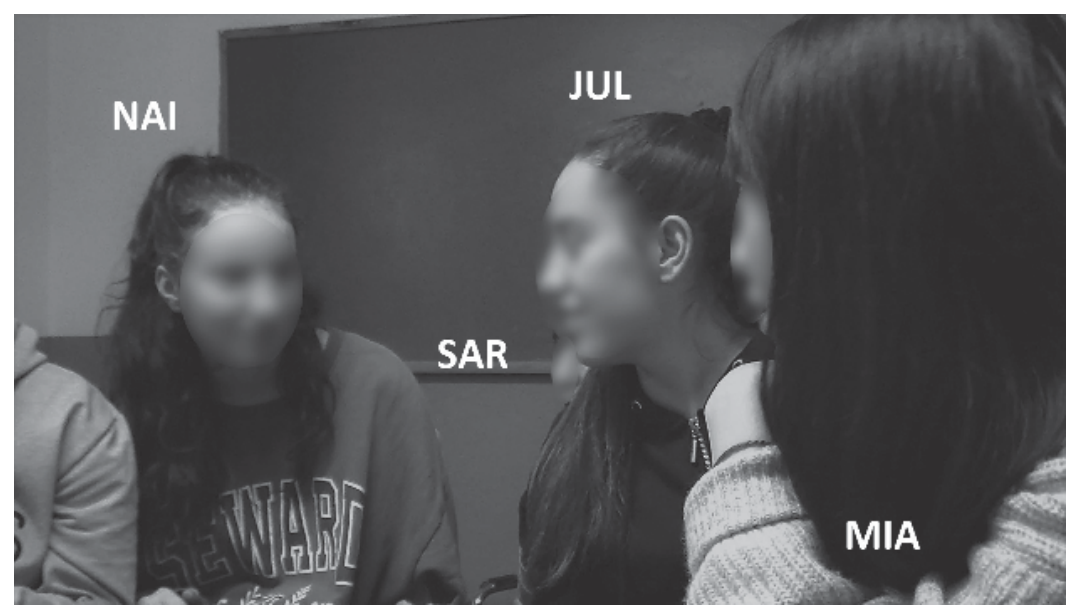

Figure 13.3 Screenshot from line 29

about her preference for the church ("ask her Naiara, ask her why"), which Naiara does in line 24 ("why?"), prompting embarrassed laughter from Sara. In line 26, Miaomiao repeats Naiara's question, as though she is unaware that her taste for the church is an issue for discussion. At this point, Julián, who until now had not spoken, addresses Naiara in Spanish and asks her if she is surprised by Miaomiao's fondness of the church ("¿te sorprende?", line 28), to which Naiara responds with a "no" without moving her gaze from Miaomiao, awaiting her answer.

Miaomiao's response to Naiara in line 30 ("because is beautiful, the weather's beautiful") reproduces Nanyamka's earlier utterance from line 13, while also proving that Miaomiao has not followed the course of the young people's exchanges or the reason for the confusion. In her next turn (line 31), Nanyamka also requests Miaomiao's clarification by asking "but here or in Barcelona?", thus adjusting the shared contextual reference from the scale of the nation-state to a more local one (i.e. "here" in the municipality where the project takes place, or the city of Barcelona). This request to rescale the place of reference suggests that Nanyamka is trying to plausibly align Miaomiao's preferences with the young people's normative expectations of her. While Barcelona is an international tourist destination due in part to its architecture, including its churches, the young participants had previously discarded the church in their own town as a place for recording material for a digital story. If Miaomiao liked the touristic churches in Barcelona, it could be counted as a common-sense attribute of her as a Chinese person in Spain, while liking non-touristic churches or the Catholic church as an institution would be less normative. 


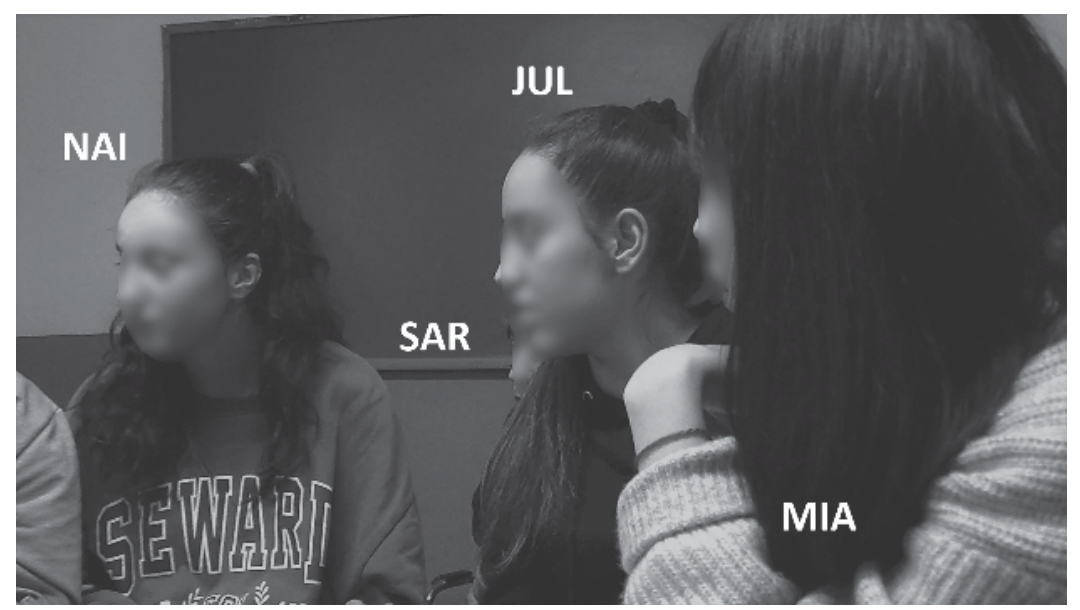

Figure 13.4 Screenshot from line 33

In line 33 and overlapping with Nanyamka's question, Naiara formulates a different one ("you are Christian or?") which reinforces the young people's need to accommodate Miaomiao's liking for church with their membership categorisation work and prompts further enquiry and discussion. In line 34, Miaomiao responds to both Nanyamka and Naiara by saying that she likes the weather and/or churches (depending on what she has understood as the focus of the discussion) "both" in Barcelona and in the town. She then repeats Naiara's question with rising intonation ("Christian?"), showing her ongoing confusion and/or seeking clarification. Meanwhile, Naiara looks at Nanyamka for language assistance (line 33, see Figure 13.4) and Nanyamka rephrases and implicitly corrects the question in English for Miaomiao (line 35). Miaomiao then responds that she is not Christian, but she finds church beautiful (line 36).

The interaction here develops into two parallel enquiries about Miaomiao's religious interests. In line 37, looking at Naiara, Nanyamka expresses her belief, in Spanish, that Miaomiao is Buddhist, although using the inexact term "Buda" (and later also its plural and inexistent form "Budos"). Naiara responds by asking why Miaomiao would go to a church that worships the Christian God (lines 39 and 41), to which Nanyamka aligns by commenting that church is indeed not for Buddhists (lines 43 and 46). While their vocabulary might express a certain lack of familiarity with the subject of Buddhist religion, their exchange voices several stereotypical understandings held by them, including that Chinese people are Buddhists, that all Spanish churches are Christian and that only Christians would take an interest in them. 
In an overlapping sequence that seems to follow the same rules of category building (and exclusion), Sara addresses Miaomiao - with Claudia's language assistance - to ask if there are churches in China (lines 38, 42, 44-45). Miaomiao responds that there are no churches in China, only temples, which suggests alignment between her own understandings of China with the girls' expectations of religious beliefs and places of worship in Spain and China. In the final part of the fragment (lines 48-53), the two parallel conversations converge as Naiara, Nanyamka and Sara bring their information together to collaboratively build a consensual explanation, in Spanish, of Miaomiao's liking of churches as beautiful places that are non-existent in China. They make sense of Miaomiao's taste for Spanish churches for aesthetic rather than religious reasons within their normative expectations for a young Chinese Buddhist woman in Spain (although part of this categorisation - being Buddhist - was never confirmed by Miaomiao).

We now turn to the discussion and implications of this fragment.

\section{Conclusions}

The analysis offers insights into participants' situated and collaborative production of understandings of people and places, in ways that build from but also challenge their preconceived ideas. For educational purposes, it is significant that the participants do not move beyond stereotypical understandings of themselves and others in their membership categorisation work. However, the disbelief generated by Miaomiao's fondness for the church reveals the young girls' category-bound expectations of her and sheds light on how identity is both built and contested in social interaction; in this case, by transgressing stereotypical understandings of what a young Chinese woman should like about Spain. This confrontation between the young people's preconceived ideas and the reality presented by Miaomiao, and the ensuing process in which the young people seek to reconcile their common-sense understandings and the conflicting information emerging in the interaction, is arguably a first step in promoting more complex and nuanced worldviews.

The fragment also shows how this social process takes place and is possible through a bricolage of diverse linguistic codes, modalities and media, in what we understand as transidiomatic practices. It is significant to note how the young people bring Chinese into the interaction through the Google Translation tool. We explain this both in terms of play and in terms of the young people's deference and desire to make a connection with Miaomiao through the language. Our ethnographic work has also revealed the important role of digital devices and the Internet in providing the young people access to Asian pop cultural references, which arguably fuel their imaginations and expectations about young Chinese women in Spain. Finally, Spanish emerges in side-sequences in the excerpt and scaffolds both the young people's production in English and their configuration of membership categories. 


\section{Acknowledgements}

The work presented here was carried out as part of the research project 'Inclusive epistemologies and practices of out-of-school English learning' (IEP!), funded by FEDER/Spanish Ministry of Science, Innovation and Universities. Reference number PRPPGC2018-099071-A-I00. Principal investigator: Emilee Moore.

The after-school site where the interaction takes place is part of the transnational, digital storytelling project Global StoryBridges, led by Professor Margaret Hawkins of the University of Wisconsin-Madison. See www. globalstorybridges.com.

\section{References}

Antaki, C., \& Widdicombe, S. (Eds.). (1998). Identities in talk. London: Sage Publications. Blommaert, J., Westinen, E., \& Leppänen, S. (2015). Further notes on sociolinguistic scales. Intercultural Pragmatics, 12(1), 119-127.

Cameron, D. (1990). Demythologizing sociolinguistics: Why language does not reflect society. In J. E. Joseph \& T. J. Taylor (Eds.), Ideologies of language (pp. 79-93). New York: Routledge.

Goffman, E. (1974). Frame analysis: An essay on the organization of experience. New York: Harper and Row.

Goffman, E. (1981). Forms of talk. Philadelphia, PN: University of Philadelphia Press.

Goodwin, C., \& Duranti, A. (1992). Rethinking context: Language as an interactive phenomenon. Cambridge: Cambridge University Press.

Gumperz, J. (1964). Linguistic and social interaction in two communities. American Anthropologist, 66(6), 137-153.

Hawkins, M. (2014). Ontologies of place, creative meaning making and critical cosmopolitan education. Curriculum Inquiry, 44, 90-112.

Hawkins, M. (2018). Transmodalities and transnational encounters: Fostering critical cosmopolitan relations. Applied Linguistics, 39 (1), 55-77.

Jacquemet, M. (2005). Transidiomatic practices: Language and power in the age of globalization. Language and Communication, 25, 257-277.

Jacquemet, M. (2016). Sociolinguistic superdiversity and asylum. Tilburg Papers in Cultural Studies, 171. www.tilburguniversity.edu/upload/044f1c13-9381-4d74-af3d8813d9fa64f3_TPCS_171_Jacquemet.pdf.

Moore, E., \& Vallejo, C. (2018). Practices of conformity and transgression in an out-ofschool reading programme for 'at risk' children. Linguistics and Education, 43, 25-38.

Psathas, G. (1999). Studying the organization in action: Membership categorization and interaction analysis. Human Studies, 22, 139-162.

Sacks, H. (1974). On the analysability of stories by children. In R. Turner (Ed.), Ethnomethodology: Selected readings (pp. 216-232). Harmondsworth: Penguin.

Schegloff,E.A. (1992). In another context. In C. Goodwin, \& A.Duranti (Eds.), Rethinking context: Language as an interactive phenomenon (pp. 191-227). Cambridge: Cambridge University Press.

ten Have, P. (2002). The notion of member is the heart of the matter: On the role of membership knowledge in ethnomethodological inquiry. Forum: Qualitative Social Research, 3(3), 1-24. www.qualitative-research.net/index.php/fqs/article/view/834/1813. 
Vallejo, C., \& Dooly, M. (2020) Plurilingualism and translanguaging: Emergent approaches and shared concerns. Introduction to the special issue. International Journal of Bilingual Education and Bilingualism, 23(1), 1-16.

Vianna, E., \& Stetsenko, A. (2014). Research with a transformative activist agenda: Creating the future through education for social change. In J.A.Vadeboncoeur (Ed.), Learning in and across contexts: Reimagining education (pp. 575-602). NewYork:Teachers College, Columbia University.

Wadensjö, C. (1998). Interpreting as interaction. New York: Addison Wesley Longman. 
Plurilingualism in student's international encounters 


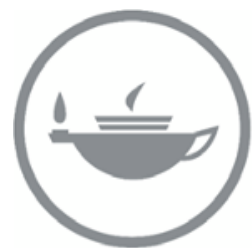

Taylor \& Francis Taylor \& Francis Group http://taylorandfrancis.com 


\title{
Professional language \\ in automotive maintenance \\ training
}

\section{Translocal intercomprehension between students from Barcelona and Lyon}

\author{
Víctor Corona
}

\section{Introduction}

Globalisation has altered reality in the workplace and the demands placed on professionals go beyond the fulfilment of their specific job duties. Often, the division between low and high-skilled jobs are drawn onto the qualifications of workers with regards to their technological skills, their competence in reading and interpreting professional texts and their abilities to communicate with customers. As Duchêne (2009) points out, workers' discursive competence constitutes both a symbolic and an economic capital. Additionally, Filliettaz (2010) argues that learning to work and becoming a member of professional communities very much rely on discourse and interaction. These discourses provide accounts of the ways individuals engage with the process of training and learning, and can be regarded as valuable methodological resources for understanding the complex processes associated with vocational education.

The study presented here is based on a multi-situated methodological approach influenced by research in the fields of linguistic anthropology, plurilingual interaction and vocational training. Our approach to vocational education is based on an interactionist perspective and subscribes that learning is socially situated and, therefore, professional knowledge and skills are built collectively when learners have access to both theory and practical experiences in specific training or professional environments (Filliettaz, 2009). We examine the plurilingual and multimodal practices employed by two groups of vocational students enrolled in automotive maintenance training programmes in different countries (one in Lyon, France, and the other in Barcelona, Catalonia). We play special attention to the type of intercomprehension procedures learners put at play during their participation in translocal communicative tasks. Thus, the first part of the chapter analyses some of the theoretical dimensions embraced in our study with regards to vocational education. Then we describe the ethnographic and didactic procedures adopted to gather our data. Finally, we provide 
samples of our analysis of learners' discourse, discuss our results and present some concluding remarks.

\section{Discourse competences in automotive maintenance training}

The job of an automotive machinist does not merely rely on the ability to perform a manual job. Car engines are complex machines and engine work and repair entails understanding how car systems and components relate. Developing discourse written competences is important for automotive machinists because, in order to interpret engine malfunctions and failures, they often need to carefully understand explanatory or descriptive documents that relate how certain car parts function and interact. Oral competence is also essential to be able to report the problems detected during the execution of certain training tasks. Consequently, students need to develop their discursive competence to be able to follow their training courses and also to act as automotive machinists. If students in the two vocational training schools are not able to express themselves, orally and in writing, and relate technical contents, they are not regarded as apt professionals and are not awarded the certificate that qualifies them as automotive machinists. Thus, in Lyon as well as in Barcelona, 'being an automotive machinist' is a complex task whose accomplishment relates both on trainees' ability to 'provide engine work and repair' as well as on their knowing how to 'talk like an automotive machinist' (Lambert and Veillard, 2017).

However, developing professional discursive competences is not an easy task as it does not solely rely on employing linguistic elements. As Goodwin (2000, 2013) suggests, human communication is supported not only by talk, but also by a set of other elements embodied in the interaction. In this sense, competence in the context of our study relates to mastering technical vocabulary, adhering to the aesthetics of hypermasculine language (Alcade-Lebrun et al, 2019) and relying on postural and ergonomic elements necessary during training. Thus, we regard students in the two educational settings as members of the same translocal community because, in spite of their distinct linguistic repertoires, they share similar trajectories, social positions, and, above all, a common professional language. Communication between the two groups is possible because the type of body movements and gestures they employ are part of what constitutes shared professional language in that emergent translocal community (Peleikis, 2004). Thus, our study examines how during talk-in-interaction students co-construct the shared verbal multimodal resources that would shape the development of their translocal communal identity (Appadurai, 1990).

\section{Reporting a translocal learning experience}

Our study relies on anthropological observations conducted, for a period of 16 months, in two vocational training centres offering automotive maintenance 
courses. Most of our time was spent in the school sited in the city of Lyon (France). Compared to the centre located in the city of Barcelona (Catalonia), the school in Lyon has more ample facilities, more updated machines and offers students the opportunity of working in groups. Resources in the vocational school sited in Barcelona are scarce and often not enough to perform all the necessary training tasks, facilities are small and teachers have large number of students in their classrooms. From a pedagogical viewpoint, differences between how the two vocational institutions present theoretical and practical contents are also significant. The practical lessons in Lyon are conducted in workshops and through a hands-on approach: students, in pairs, carry out repair operations in real cars. Classes in Barcelona are based on theoretical explanations. Despite these differences, we could observe that both contexts share certain social practices that result in similar discursive practices.

To obtain our data, we developed a learning project that required students to create descriptive video clips to present their schools and the kind of training activities they were engaged in. Students in Barcelona created their videos in Spanish and students in Lyon did so in French. We depart from the premise that the multimodal nature of students' videos and learners' mastery of professional language would aid the intercomprehension of those texts in the translocal community. We define the experience as being translocal because during the development of the learning project two groups of learners with different languages and cultures were interconnected to develop a professional training task. Such deterritoralised practice allowed learners to jointly develop their communicative and professional competences.

From a methodological point of view, our study is framed into the field of multi-sited ethnography (Marcus, 1995; Hannerz, 2003; Mondada and Nussbaum, 2012) and seeks to understand certain discursive practices in international communication (Blommaert, Colins, and Slembrouck, 2005; Blommaert, 2010). We particularly want to explore how a similar training trajectory and access to a shared professional language allow translocal students to understand videos produced in a language they do not know. Our learning proposal is based on the principles of project-based learning, especially on the idea that such approach favours learning because it offers students the possibility of acquiring field knowledge and developing multiple skills through action, that is, by engaging in tasks similar to those they encounter in their everyday lives (Dooly and Masats, 2020).

The initiative of developing a joint project between the two vocational training schools was motivated by the interest of the students in Lyon in knowing what vocational education was like in Barcelona. Our experience in doing ethnographic research in Catalonia (see Corona, 2016) served as a departing point. The school board of the vocational school in Barcelona accepted our proposal for collaboration. Initially we wanted to compare the teaching approaches in both institutions, but students and teachers immediately proposed to establish some sort of direct contact. Students in Barcelona 
took the initiative and sent students in Lyon pictures of their group and their facilities. As an anecdote, we would like to mention that on seeing the pictures one of the students in Lyon was surprised and commented that student in Barcelona were "latinos" and that "latinos were the Arabs in Barcelona" (note on fieldwork entry 30.03.2016). Something similar occurred in Barcelona when they observed that most students in Lyon were of Arabic origin. This sort of observations became important elements to establish communicative bonds, beyond words, among the members of this translocal community. Soon students and their teachers engaged in ethnographic work and learnt that learners in both education settings shared similar situations, social roles, academic trajectories, professional expectations, music preferences but also a common language that transcended their mastery of French or Spanish. Students were trained for the same job and, although they could not understand the exact words used by their peers, they were able to understand the operations others were performing, to identify car spare parts and to recognise repair procedures.

So, students communicated asynchronously through video-recordings. We thought that getting students to record videos and edit them to select particular clips or add subtitles would allow them to recognise commonalities and differences between the types of training tasks the two groups were engaged in. Students could not communicate spontaneously in real time, but the possibility of watching the video clips more than once allowed them to progressively get to grips with what was being said.

\section{Communication mediated through images and by the use of professional language}

The first videos students exchanged were related to their training tasks and daily routines at each school. They described the topics they were dealing with in class and the procedures they were experimenting. All students were surprised to realise there were so many differences between the two schools and often pointed out that the type of facilities they had (or lacked) access to had an impact on what they could learn. At first, they did not expect to be able to understand the contents of the videos they would receive but, through the images, they soon realised they shared a common professional language. They could also state that Catalan, Spanish and French were not very different languages.

After these first video exchanges, the students in Barcelona and their teachers decided to pose 'mechanical challenges' to students in Lyon. Challenges were formulated in terms of questions students should respond to with regards to their knowledge of engine work and repairs they considered to be basic. Teachers in Barcelona designed an evaluative task for their students, who were given a card with a picture of a car spare part (e.g. a temperature sensor) or a diagram and had to describe its function. Then they had to formulate a 


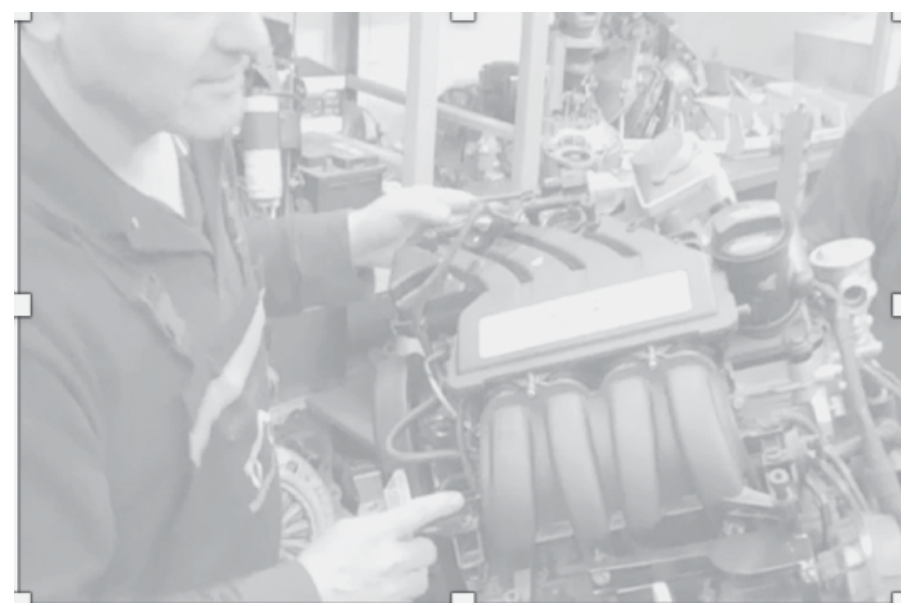

Figure 14.I Student in Barcelona talking while pointing at the parts of a car engine

multiple-choice question addressed to the students in Lyon. When this was ready, students selected the settings for their recordings. Teachers were satisfied with the results and, as researchers, we felt we had contributed to the implementation of a meaningful methodological classroom proposal.

We will now analyse how students in Barcelona engaged in the task we have just described.

\section{Excerpt 1}

Participants: Esteban (EST) \& Eric (ERI)

EST: ((standing in front of a car engine, see Figure 14.1))

en esta oportunidad $\backslash($.)estamos con un motor de gasolina $\backslash($.)

in this opportunity(.) we are with a petrol engine $\backslash($.) 

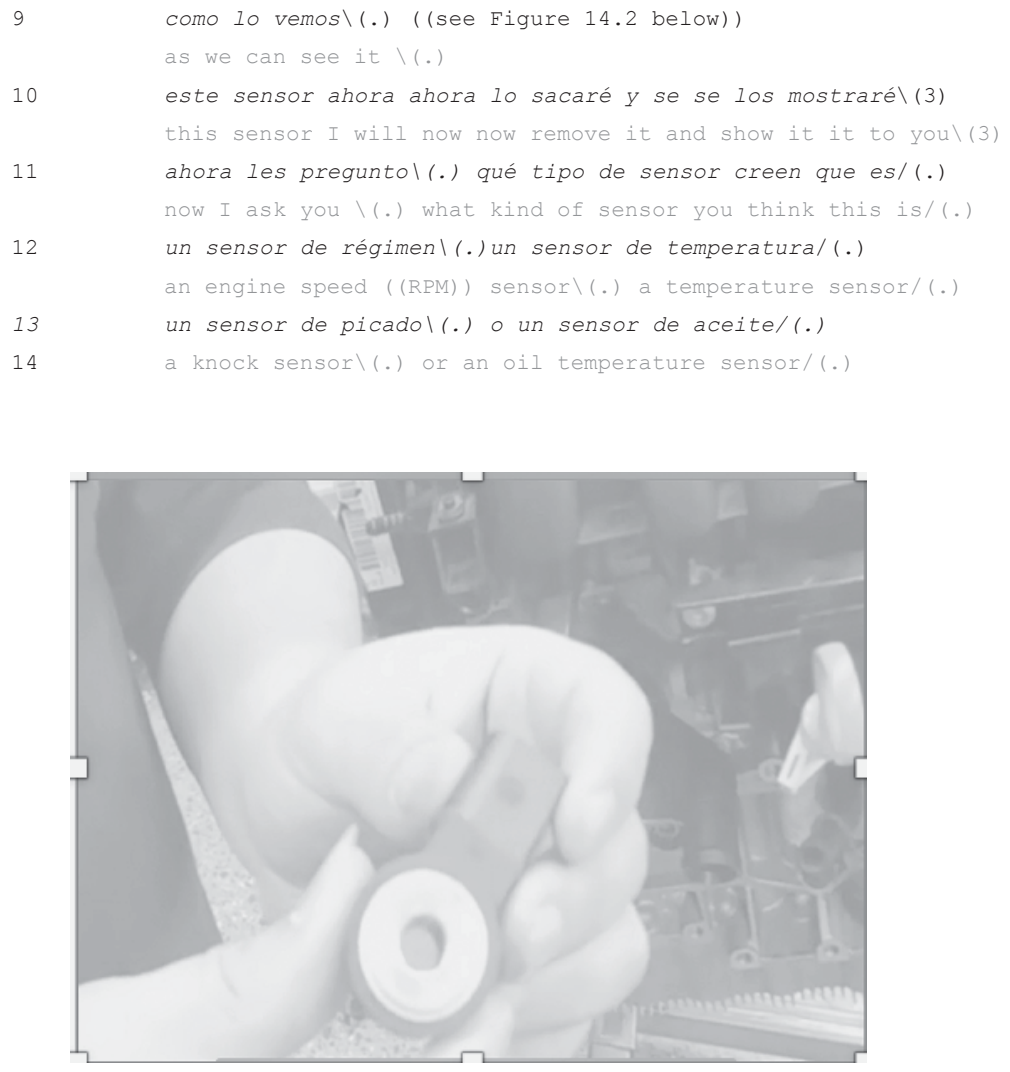

Figure /4.2 ERI shows the sensor and moves it while he holds it in his hands

As we can see in excerpt 1, EST stands in front of an engine (see Figure 14.1) and proposes a discursive framework composed of a series of key words like 'petrol engine', 'petrol direct injection engine' or 'static direct ignition system' (lines 2-4) as an introductory statement to the questions his classmates are about to formulate. ERI takes the floor to indicate where the sensor is located in the engine (lines 8-9). His words are accompanied by the camera moves he makes. Immediately after, he removes the sensor, shows it on to the camera, moves it and poses his question and four answer choices, which all contain technical words, too (lines 11-13). So, information is delivered multimodally.

In excerpt 2, we can observe how students in Lyon look at the screen to watch the video (see Figure 14.3) and try to interpret this same message. 


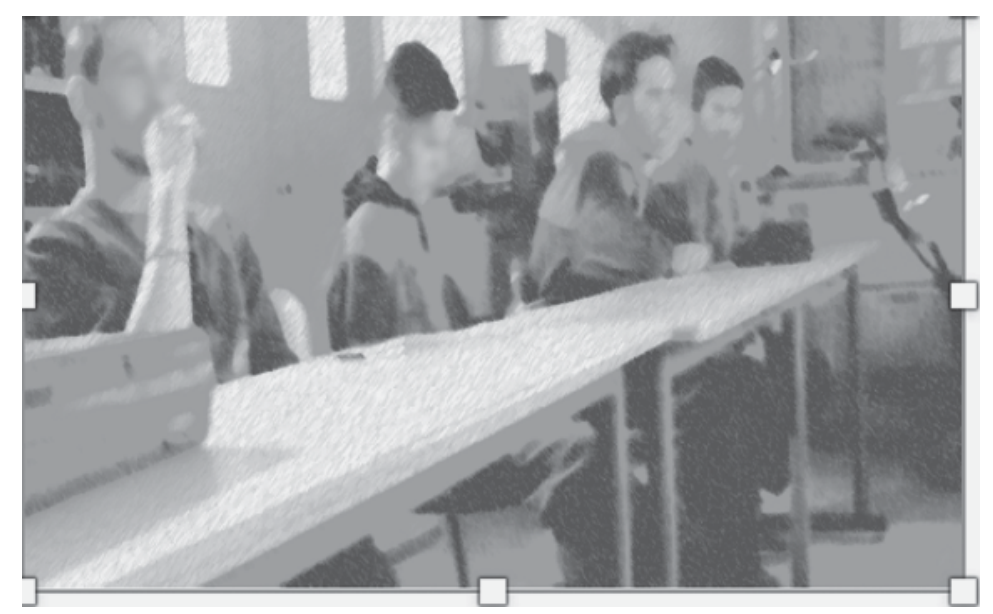

Figure I 4.3 Students in Lyon watching the video from the students in Barcelona

Excerpt 2. Participants: Joao (JOA), Bastien (BAS), Pierre (PIE), students in Lyon; STU, students in chorus, Victor VIC, researcher; VHV, voices heard in the video

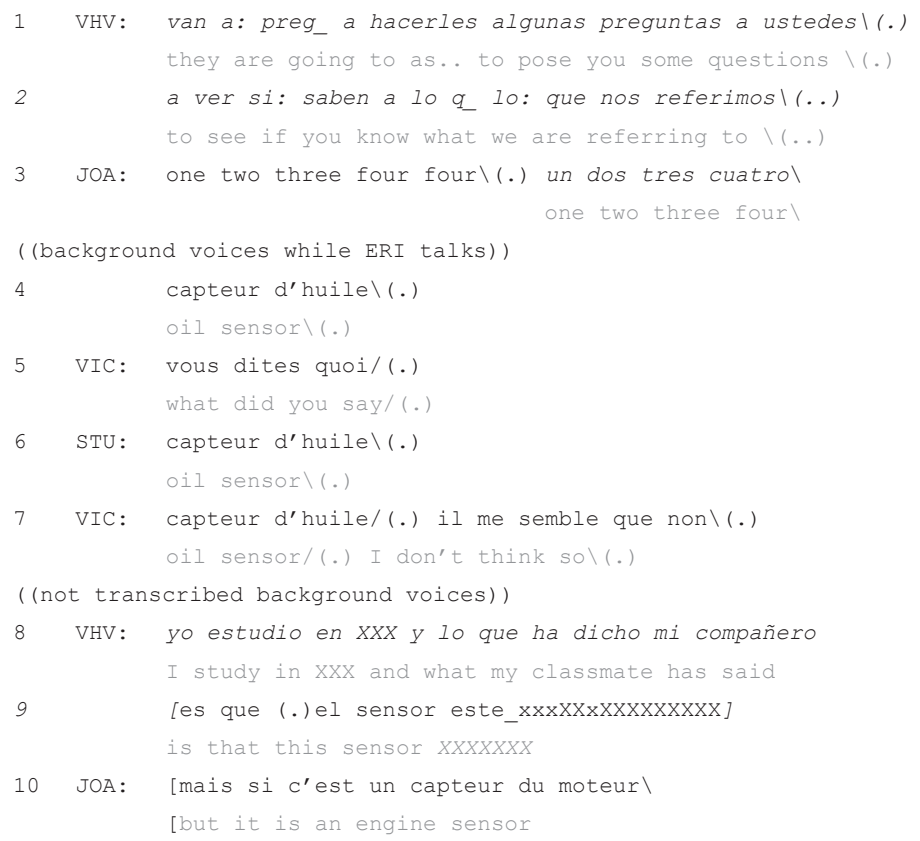


11 c'est un capteur d'huile]

it's an oil sensor]

12 VHV: es un sensorl(.) que envia la información a una centralita_ (.)

it is a sensor $\backslash($.) that sends information to a module (.)

13 JOA: mais ils apprennent beaucoup hein/(.)

but they learn a lot eh/(.)

peut être ils ont pas de voitures mais ils apprennent beaucoup $\backslash($.)

maybe they don't have cars but they learn a lot $\backslash($.)

( (the background voice of one of the students in Barcelona can still be overheard))

15 VIC: quoi/(..)

what $/(\ldots)$

16 JOA: ils ont peut être pas de voitures $\backslash($ (.) mais ils apprennent beaucoup $\backslash($ (.) they may not have cars $\backslash$ (.) but they learn a lot $\backslash($.)

17 BAS: ils ont de nouveaux moteurs $\backslash($ (.) nous on a des vieux moteurs pourris $\backslash($.) they have new engines $\backslash$ (.) we have old rotten engines ${ }^{a}($.)

18 VHV: el sensor de fase o inyector de combustible XXX

the camshaft position sensor or fuel injector

19 PIE: ((reads in Spanish)) inyector de combustible (.)

fuel injector $\backslash($.

JOA: mets pause et reviens en arrière avec les propositions $\backslash$ (2)

play pause and go back to the proposals $\backslash(2)$

mets pause dans les propositions $\backslash($.)

pause at the proposals $\backslash($.)

VHV: ahora les pregunto $\backslash($.$) qué tipo de sensor creeen que es / (.)$

now I ask you $\backslash($.) what kind of sensor you think this is/(.)

VIC: capteur de régime $\backslash($.

engine speed sensor $\backslash$ (.)

JOA :

ouais \(.)

yeah (.)

VHV: temperatura del aire o inyector de combustible XXX

air temperatur or fuel injectorXxx

26 VIC: moi je pense $C^{\prime}$ est un capteur de phase $\backslash($.

I think it is a cam phase sensorl(.)

27 JOA: mets pause mets pause (2) c'est quoi la fase/(.)

pause pause what is the phase/(.)

VIC: sais pas $\backslash($.

don't know $\backslash($.)

PIE: la fase c'est la phase $($ (.)

the phase is the phase $\backslash($.

((students discuss))

30 VHV: ahora les preguntol(.) qué tipo de sensor creen que es/(.) now I ask you $\backslash($.) what kind of sensor you think this is/(.) mi compañero ya lo ha dicho\(.) my classmate has already said it (.) pero de las cuatro opciones $\backslash($.) but from the four options $\backslash($.) 


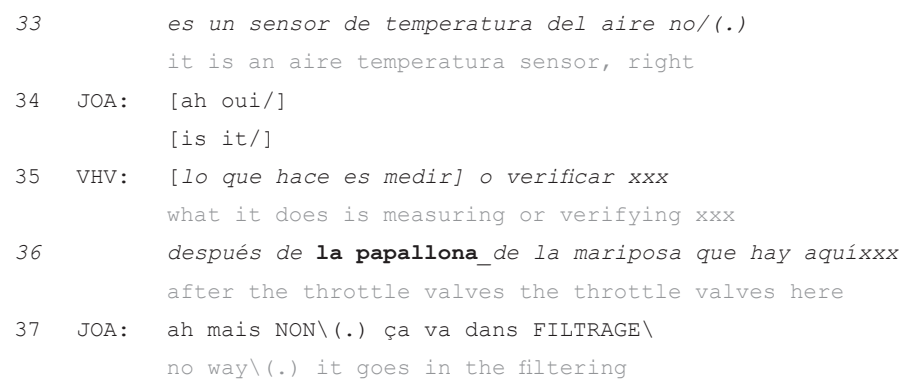

In line 3, JOA makes a joke and starts counting, in English and Spanish, as if signalling a show is about to start. Then, after listening to the four options given by the students in Barcelona, he opts for the one that mentions 'oil sensors', which indicates he attributes a technical term to the image shown (Figure 14.2) and described (lines 8-10 in excerpt 1 ) by ERIC.VIC questions JOA's choice (lines 5-7), but JOA insists without paying attention to the video on the screen. Instead, he provides an explanation (lines 11-12). Later on, he seems to watch the video and makes an evaluative comment on what students from Barcelona have learnt (lines 13-14).VIC has not understood his comment and formulates a clarification request (line 15). JOA reformulates his evaluative comment (line 16), which leads BAS to compare the kinds of engine they have with the ones available for the students in Barcelona (line 17). Then PIE reads aloud a fragment of the subtitles in Spanish (line 18) and JOA gets back on task and asks VIC to rewind the video to listen to the four proposals again (line 20-21) and again (line 27). While they view the recording JOA and VIC engage in a dialogue to discuss what they see and hear and suggest the possible answer (lines 20-29).

These two excerpts allow us to observe an interaction mediated by the pictures students look at. The video occasionally has subtitles with words translated, but students' discussion on the probable right answer revolves around the images they observe. Excerpt 1 reveals that students in Barcelona consciously use the images they show on the video to make meaning accessible for the students in Lyon. Excerpt 2 proves that the procedure was useful as the students from Lyon rely on those images to interpret the message in the video and construct meaning. Students in these groups are plurilingual speakers (they all speak other languages apart from the one used to create/make sense of the videos), who are able to activate their linguistic repertoire to engage in the task at hand. The students in Barcelona know how to adapt their discourse to a group of people who do not know their language and the other group knows how to decipher a message in a non-familiar language by making connections between the target language and the languages they know. Reliance on resources such as images, gestures and common background professional knowledge, as well as the possibility of watching the video more than once, also contributed to make communication possible. 
Students value the discursive procedures used by their peers. In this sense, when JOA in line 17 (excerpt 2) states that the students in Barcelona learn a lot in spite of not having real cars to practice mechanical operations, he is somehow evaluating the communicative competence of their peers. We would argue that JOA implicitly states that ERI and EST are good automotive machinists because their discourse is good, as they are able to talk about and illustrate engine work.

\section{Conclusions}

The data we have presented is limited but, in our opinion, it allows us to make a call for the study of vocational education from an anthropological and linguistic perspective. We cannot understand the complexity of today's multilingual and diverse society without examining the links between the development of language skills and the social construction of meaning. Contexts like the one in our study cannot be left aside.

The pedagogical task set to two groups of vocational students consisting in exchanging videos to share professional contents in the field of automotive maintenance training serves a double objective. First it was a learning task that would be assessed and that triggered students to activate their plurilingual and multimodal resources to produce or decode a text. Second it was a tool for collecting data on classroom discourse. Our results demonstrate that in the two vocational schools in our study (one in Barcelona and one in Lyon) discursive competences are of crucial importance in the training process. Learners are expected to know how to perform specific required mechanical operations, but they also need to prove they know how to refer to those operations, both orally and in writing. On doing so, learners in our study rely on the use of multimodal resources (gestures, pictures) and the employment of technical knowledge that transcends language boundaries. This explains how two groups of learners using non-shared languages succeed in developing intercomprehension skills to understand each other.

\section{References}

Alcade-Lebrun, C., Corona, V., Garrido, M. R., Petit Cahill, K., Pelé-Peycelon, M., \& Sokolovska, Z. (2019). Les pratiques langagières et textuelles dans l'ethnographie des institutions: Enjeux méthodologiques et conditions de production de connaissances sociolinguistiques. Actes du Congrès RFS 2017 (pp. 421-449). Lambert-Lucas:Limoges.

Appadurai, A. (1990). Disjuncture and difference in the global cultural economy. Theory, Culture and Society, 7, 295-310.

Blommaert, J. (2010). The sociolinguistics of globalization. Cambridge: Cambridge University Press.

Blommaert, J., Collins, J., \& Slembrouck, S. (2005). Spaces of multilingualism. Language \& Communication, 25, 197-216. 
Corona, V. (2016). Latino trajectories in Barcelona: A longitudinal ethnographic study of Latin American adolescents in Catalonia. Language, Culture and Curriculum, 29(1), 27-42.

Dooly, M., \& Masats, D. (2020). 'What do you zinc about the project?': Examples of technology-enhanced project-based language learning. In G. Beckett \& $\mathrm{T}$. Slater (Coords.), Global perspectives on project-based language learning, teaching, and assessment: Key approaches, technology tools, and frameworks (pp. 126-145). NY/Milton Park, Abingdon: Routledge.

Duchêne, A. (2009). Formé-e pour servir! La part langagière de la formation professionnelle dans la nouvelle économie. Bulletin Suisse de Linguistique Appliquée, 90, 125-147.

Filliettaz, L. (2009). Les formes de didactisation des instruments de travail en formation professionnelle initiale: Une approche comparatiste. Bulletin Suisse de Linguistique Appliquée, 3(1), 26-56.

Filliettaz, L. (2010). Interactions and miscommunication in the Swiss vocational education context: Researching vocational learning from a linguistic perspective. Journal of Applied Linguistics and Professional Practice, 7(1), 25-50.

Goodwin, C. (2000). Action and embodiment within situated human interaction. Journal of Pragmatics, 32, 1489-1522.

Goodwin, C. (2013). The co-operative, transformative organization of human action and knowledge. Journal of Pragmatics, 46(1), 8-23.

Hannerz, U. (2003). Being there... and there... and there! Reflections on multi-site ethnography. Ethnography, 4(2), 201-216.

Lambert, P., \& Veillard, L. (2017). L'atelier, les gars et la revue technique. Pratiques et différenciations langagières en lycée professionnel. Glottopol. Parole de jeunesse. La part langagière des différenciations sociales, 29, 52-89.

Marcus, G. (1995). Ethnography in/of the world system:The emergence of multi-sited ethnography. Annual Review of Anthropology, 24, 95-117.

Mondada, L., \& Nussbaum, L. (2012). Introduction. In L. Mondada \& L. Nussbaum (Eds.), Interactions cosmopolites: L'organisation de la participation plurilingue (pp.7-27). Limoges: Editions Lambert Lucas. Retrieved from www.lambert-lucas.com/wpcontent/uploads/2020/12/OA_interactions_cosmopolites.pdf.

Peleikis, A. (2004). The emergence of a translocal community: The case of a South Lebanese village and its migrant connections to Ivory Coast. Cahiers d'Études sur la Méditerranée Orientale et le Monde Turco-iranien,30,297-318.DOI: 10.4000/cemoti.651. 


\title{
Interactional competence in transnational plurilingual peer interactions
}

\author{
Cèlia Pratginestós
}

\section{Introduction}

Enhancing learners' engagement in using and exploring a language they still do not master is a challenge most secondary teachers need to face in English as a foreign language (EFL) classrooms. Yet, triggering students' need for communicating to one another in a language other than the one they use to socialise within the group is not an easy task. It is our belief that teachers can reverse the situation by providing learners with opportunities to participate in transnational plurilingual interactions with peers. In such practices the use of English goes beyond the classroom walls, which creates a need to use English and occasions for genuine communication. In turn, these initiatives also create a 'space for learning' (Walsh, 2011) as students can practice the target language and deploy their Interactional Competence (IC) through the mobilisation of plurilingual and multimodal resources.

This chapter will focus on how participants in transnational plurilingual interactions use English-as-a-lingua-franca (ELF), a mediating communication tool in and outside the classroom, and also will explore the resources they mobilise when exposed to the opportunities for real communication with peer students with a different L1. On the one hand, we will look at how learners organise their participation, focusing on certain aspects of the interaction and their IC deployment such as turn-taking and topic management. On the other, we will heed the plurilingual and multimodal procedures they mobilise in favour of progressivity and intersubjectivity. Towards this purpose, we have analysed two sequences of interaction - collected within the framework of a collaborative research and innovation project - recorded during the implementation of a group task (within an transnational exchange) between Greek and Catalan secondary school students. The task assigned to the learners consisted of exchanging information, in groups of four, on their own culture and lifestyle to finally report said information to the group as a whole at the end of the class. First, the theoretical framework will be laid out. Then, the methodological apparatus used for analysis will be described and, after the data analysis, conclusions will be formed. 


\section{On the nature of learner's interactional competence}

When engaging in interactions with others (both in an L1 or L2 language), we deploy our ability to accomplish meaningful social actions, to respond to co-participants' previous actions and to recognise and respond to expectations of what to say and how to say it (Hall and Pekarek Doehler, 2011; Young, 2011). IC relates to this ability as it involves deploying and recognising contextspecific patterns by which turns are taken, actions are organised on a momentto-moment basis and practices are ordered (Hall and Pekarek Doehler, 2011). The current construct of IC builds upon the concept 'communicative competence', coined by Hymes (1972) and operated and theorised by Canale and Swain (1980) and Bachman (1990), among others, in contrast to Chomsky's 'linguistic competence' (1965). The main difference between 'communicative competence' and IC, according to Young (2011: 430), is that "IC is distributed across participants and varies in different interactional practices" and, fundamentally, that "IC is not what a person knows, but what a person does together with others". Kramsch's view (1986) also clearly distinguishes IC from communicative competence arguing that IC presupposes "a shared internal context or 'a sphere of inter-subjectivity"'. The resources that participants bring to interaction, which characterise IC, were listed and classified by Young (2008: 71) within three groups: (1) identity resources (participation framework), (2) linguistic resources (register, modes of meaning) and (3) interactional resources (speech acts, turn-taking, repair, boundaries). Other forms of conduct in addition to talk (nonverbal semiotic resources) are also considered in the analysis of the completion of communicative activities (Goodwin, 2000), as indeed are verbal prosody, rhythm and intonation (Young, 2011).

Among all the types of interactions learners participate in, peer interactions provide opportunities for learning through collaborative interaction and collective scaffolding (Donato, 1994). There is consensus among researchers that interactions in paired and group tasks are particularly relevant because they offer every member in the interaction increased possibilities of participation than those offered in interactions between teachers and learners (Masats, 2008). As the author shows, in plurilingual peer interactions, without the presence/mediation of a teacher, learners dare to explore, take risks and participate both in the topic structuring, the actual interaction organisation and even in freer exploration of different linguistic forms. Understanding how participants interact with peers entails understanding how they communicate and co-construct learning in a moment-by-moment fashion within the interaction, i.e. how they deploy their IC (Kramsch, 1986; He and Young, 1998; Hall, Hellerman, and Pekarek-Doehler, 2011).

Within an L2 educational setting, as Borràs, Moore, and Nussbaum (2015) explain, participants are simultaneously responsible for managing the organisation of their talk, which resembles an ordinary conversation with various participants (Lerner, 2003), and the need to complete the task they have been 
assigned.This duality, as the authors point out, is linked to a framework proposed by Erickson (1982), which suggests an intertwined relationship between the 'Social Participation Structure' (SPS), i.e. the set of constraints on the allocation of interactional rights and obligations of the various group members, filled with conversational rules of sequence interaction (Seedhouse, 2005; Masats, Nussbaum, and Unamuno, 2007), and the 'Academic Task Structure' (ATS), i.e. the stages necessary to complete the task. The way participants orient themselves to develop and execute a task in an L2 is also central to the study of the relationship between plurilingual practices and the development of L2 communicative expertise (built on the participants' full repertoire), because, as Llompart and Nussbaum (2018) establish, plurilingual uses scaffold participation in L2 learning tasks and the eventual acquisition of unilingual competences (Nussbaum and Unamuno, 2000; Hall, Cheng, and Carlson, 2006; Lüdi and Py, 2009). This process is characterised by different stages (Llompart et al, 2019) that move from plurilingual interaction modes, where diverse resources, i.e. 'code-switching', 'code-mixing', 'fused lects' (Auer, 1999), hybrid forms, gestures, etc., are used simultaneously to manage the task or overcome communicative obstacles, to unilingual modes, where participants orient themselves towards the exclusive use of the target language. A single-case analysis cannot provide insights on this process - as a longitudinal study would indeed do - but can provide information on the specific plurilingual mechanisms deployed by participants at that very stage of the learning process. Language switching is analysed to understand the nature of the sequence and to explore how the language chosen by every participant impacts on the organisation of the following turns (Auer, 1984).

The use of diverse resources deployed by participants in ELF interactions is closely linked to the purpose of and preference for achieving interactional order while maintaining intersubjectivity for mutual comprehension (Heritage, 2007) based on the preference for progressivity (Schegloff, 2006). The maintenance of the intersubjectivity of the interaction engages participants in the treatment, prevention and repair of possible troubles and problems of understanding, whereas the preference for progressivity involves participants in the adoption of all the possible resources that enable them to go on within the current activity (Markaki et al, 2013). The procedures 'let it pass' and 'make it normal' are brought into play to accomplish the interactional order (Firth, 1996) in favour of progressivity, essential for the development of the ATS (Borràs, Moore, and Nussbaum, 2015). As Firth (1996) puts it, the concept 'let it pass' involves "the hearer letting the unclear or unknown utterance 'pass' on the assumption that it will either become clear or redundant as interaction progresses", involving passivity on the hearer's part. Conversely, "the concept 'make it normal' involves the hearer actively, though implicitly, attempting to make sense of what is being done and said" (Firth, 1996: 243). In this case, however, as the author states, the hearer avoids 'other-repairs' or 'candidate completions' as these would manifest the interlocutor's utterances being perceived as problematic. 


\section{Methodology}

Our data were collected within a collaborative research initiative targeted at empowering and enabling teachers to transform teaching practices in the English classroom through the adoption of Project-based Learning (PBL). Projects have proved to be meaningful proposals that create a real need to use English and opportunities for authentic communication (Dooly and Sadler, 2019). In this study data emerge from the implementation of a teaching proposal designed, executed and assessed in 'colabor' (Leyva and Speed, 2008; Ballena, Masats, and Unamuno, 2020), that is, through a form of 'collaborative action research' (Nussbaum, 2017; Masats et al, in press) between the author of the chapter and an in-service English teacher participating in the research study. The teaching proposal took the form of a telecollaboration and mobility project designed to offer a group of Catalan adolescents - from a public high school in the metropolitan area of Barcelona - opportunities to use and interact in English during the preparation and accomplishment of a cultural exchange and actual trip to Greece. The interaction presented here corresponds to a faceto-face encounter recorded during the development of an in-class group task (described below) when the Catalan students travelled to Greece.

We present a single-case analysis of the plurilingual peer interactions, generated during the implementation of a group task. Our approach to data stems from an ethnographic and emic perspective and is based on the theoretical and methodological premises of Conversation Analysis (CA) (Sacks, Schegloff, and Jefferson, 1974) to describe the numerous resources comprising L2 users' IC. As Balaman and Sert (2017) put it, "CA provides a complete picture of situated participant orientations mainly through the socio-analytic constructs such as turn-taking, sequence organisation, preference organisation, and repair" and enables the researcher to determine how speakers demonstrate they understand each other in the "context-shaped and context-renewing" (Heritage, 1984) character of any interaction. Through these data we focus on the impact this project has had on the L2 interactive competence of the participating secondary school students and the resources they mobilised to achieve an effective communication in ELF when interacting with peers with a different L1.

\section{Analysis}

The following excerpts correspond to a sequence of interaction in which Nerea (NER) and Laia (LAI) - Catalan - and Panagiotis (PAN) and Giorgios (GIO) - Greek - were asked by their teacher to sit in groups of four for a group discussion. Very few guidelines were given as learners were expected to talk freely about any topic they found worth sharing (related to their culture and lifestyle) for approximately 15 minutes. It is relevant to mention that both NER and LAI are using their mobile phones, which constitutes a mediation tool, to find photos of the places they are talking about and to show PAN and 
GIO. These excerpts will serve as examples of two aspects of the participants' interaction and IC deployment: (1) how learners organise their participation in interaction (SPS) and co-construct the task (ATS), and (2) how they use diverse plurilingual resources and other mechanisms in favour of progressivity while orienting to a 'unilingual mode of interaction' (Lüdi and Py, 1986 [2002]).

\section{Organising participation for task-completion}

In excerpt 1, which corresponds to minute 3:10 of a 21-minute sequence, NER and LAI are trying to come up with names of places to fulfil the requirements of the task proposed according to their interpretation of the ATS and the complete ecology of the activity.

Excerpt 1. Participants: two Catalan students, namely Nerea (NER) and Laia (LAI) and a Greek student, namely Panagiotis (PAN)

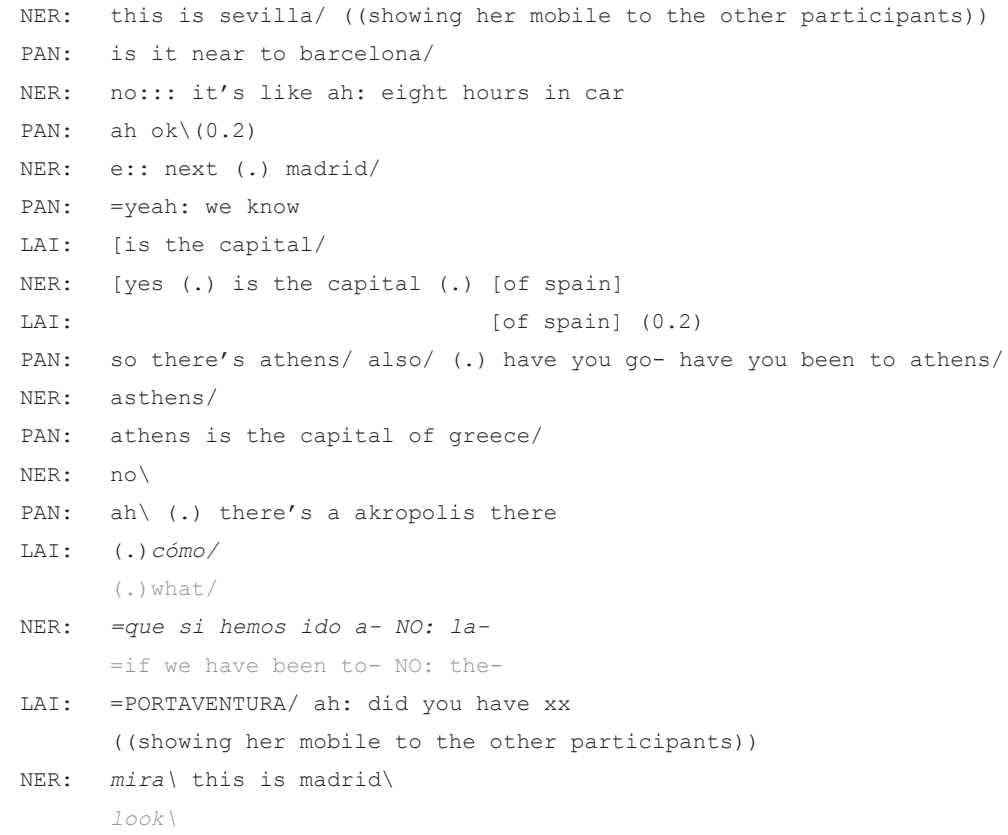

The sequence starts when NER initiates a topic talking about Sevilla (line 1) that she herself closes with another self-selected turn giving the name of another city ("Madrid", line 5). NER does not expand her self-initiated topic even though PAN has showed alignment with the topic proffered by expanding NER's topic with a follow-up question (line 2) and a validating token (line 4). Instead, in line 5, NER brings in another topic to the interaction and PAN 
responds with an epistemic stance marker (line 6) demonstrating that they are already aware of Madrid, as it is the capital of Spain. To expand (and align with) the topic NER has initiated, PAN asks NER and LAI about "Athens" (which links to the topic "Madrid" because they are both capitals). NER, however, does not seem to recognise the word (nor the connection with "Madrid") as she does not even reproduce it in the same way and utters it with a rising intonation ("Asthens"/, in line 11). NER does not acknowledge the word even though PAN has expanded the topic in favour of mutual understanding (and to avoid misalignment) with some more information on the city (line 14). The data suggest that NER does not recognise the word Athens as the translation of "Atenes" (in Catalan). We sustain that idea because of the action performed within the lateral sequence NER and LAI engage in (lines 15-16). In this lateral sequence, where they switch to Spanish to try to conjointly solve the misunderstanding, we appreciate that NER (line 16) starts translating PAN's question in line 10, but interrupts her own utterance with a "NO: the..." as if she does not associate the word Athens ("Asthens", for her) with the capital of Greece, "Atenes" (in Catalan). She does not complete her turn (so we cannot confirm our analysis), however, because LAI, who is still looking for photos of places on her mobile to share with the group, interrupts NER (line 17), with an abrupt topic shift to name another place, a theme park, to probably restart the dynamics of the task (and in favour of progression), which brusquely breaks alignment with the previous turns.

The actual sequence of the task, consisting of bringing up different topics to the conversation, nearly as a 'competition' to demonstrate who has the nicest places in their countries, and the possible participants' interpretation of the ATS, may have contributed to the development of the interaction, so far: fast turn distribution with short turns, no turn allocation and misalignment (as they do not seem to find a topic of shared interest). The irruption of the topic "Portaventura" (line 19), a theme park, however, generates a change of the interaction dynamics as participants seem to find a common interest and align with the other participants, increasing intersubjectivity among them. The participants have finally achieved alignment (through a common ground topic) after bringing up different topics that had not been so productive for the task development nor so successful in terms of intersubjectivity to date. This new productive dynamics continues in excerpt 2 when NER initiates another selfselected turn introducing the topic of the "parties of city" (line 1, excerpt 2).

\section{Mobilising plurilingual and multimodal resources}

Excerpt 2, which corresponds to minute 5:40 of the 21-minute interaction, allows us to identify how the participants orient themselves to a unilingual mode of interaction, although they rely on plurilingual resources and other mechanisms to overcome obstacles and complete the task. 
Excerpt 2. Participants: three Catalan students, namely Nerea (NER), Laia (LAI) and Alaae (ALA) and a Greek student, namely Panagiotis (PAN)

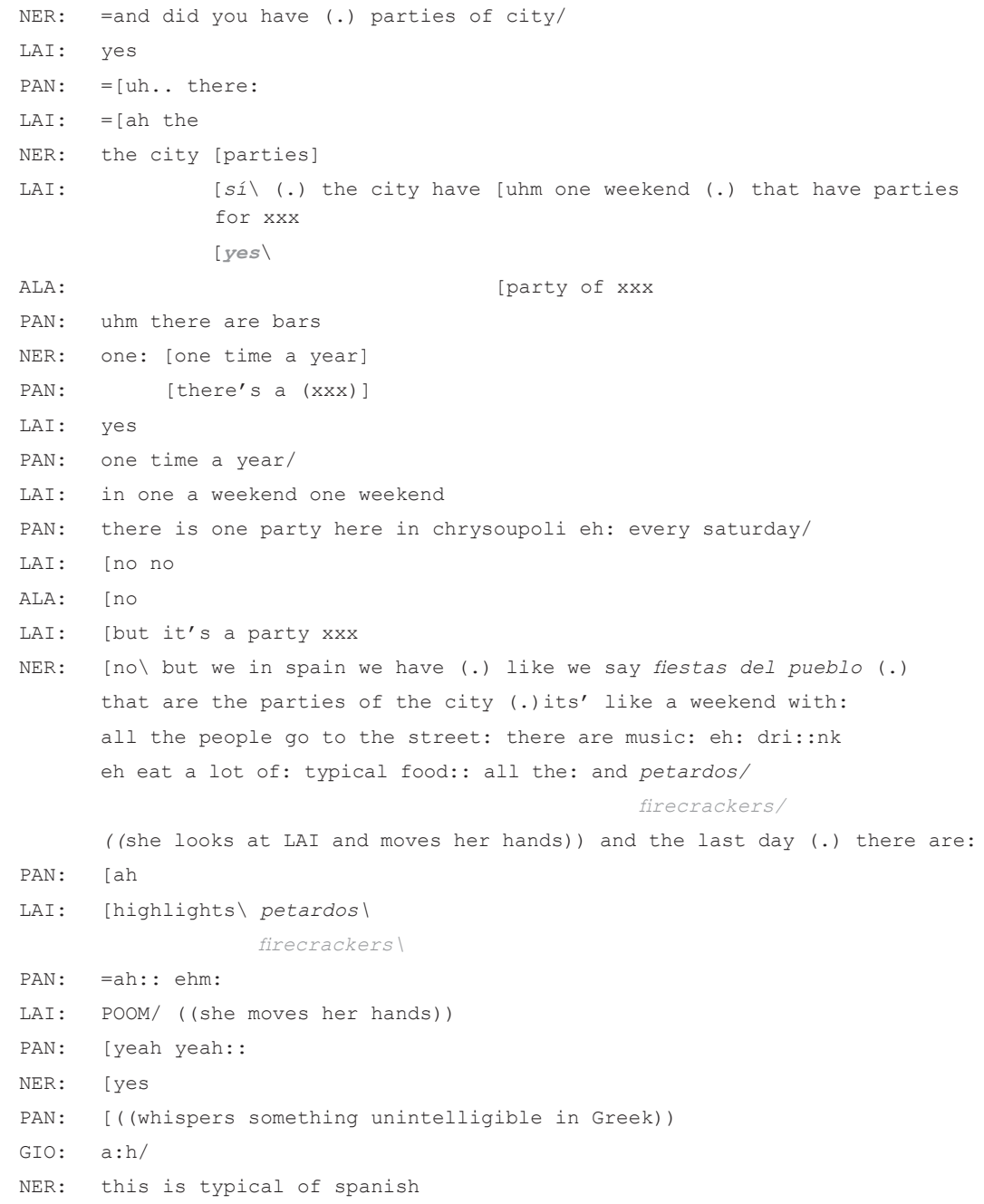

Focusing on the plurilingual resources participants mobilise, we identify a whole sequence in this excerpt about the topic proffered by NER, the "parties of city" (line 1), referring to the local festivals taking place once a year in most towns around Catalonia and Spain. In line 1 we see how NER clearly orients herself to a unilingual mode of interaction when she performs a word-to-word translation of "fiestas de ciudad". We can identify, however, she is aware that the concept "parties of city" might not be understood by the receiver when she, 
in favour of mutual understanding, reformulates the phrase in line 5 ("the city parties") and expands the topic with more information (line 9) and a whole description in lines 18-21. Actually, from line 18 to 21 NER engages in a description task offering a lot of details and even decides to switch codes ("like we say fiestas del pueblo", in line 18) with the objective of contributing to the illustration of the concept. It is not until line 30 that NER signals the end of the sequence with an utterance that appears as a summary of the whole topic on the "parties of city". Within this description we can also see that she uses another word in Spanish ("petardos", in line 21). In an attempt to continue orienting to a unilingual mode, however, NER starts a word search. She does so by resorting to LAI uttering the word in Spanish (code-switching to direct the message to one specific participant exclusively; Auer, 1999), as if expecting LAI to scaffold her with the word in English. Instead, LAI moves her hands, possibly representing fireworks, and uses the onomatopoeia "POOM". Yet NER does not interrupt her turn and strives to continue her description in English.

Within this sequence we can also observe different occasions in which LAI and also another Catalan student, ALA, (in lines 7 and 16) take turns to help in the definition and clarification of the concept "parties of the city". LAI does a topic expansion to NER's topic-initiation turn, validating NER's new idea with a "yes" in line 2, and expanding the topic with some more details in lines 4, 13 and 17. In order to make the interaction progress and flow smoothly, LAI also orients herself to a unilingual mode of interaction when she offers the translation to the word "petardos" as a response to NER's request. She does not appear very confident about her contribution ("highlights", in line 24), though, because she immediately resorts to the word "petardos" in Spanish again and makes a sound and moves her hands (using multimodal resources) to illustrate the whole idea.

Within the interaction, we have also identified other procedures participants mobilise in favour of progressivity and intersubjectivity to let anomalies and misunderstandings 'pass' where these are considered to be transparent and/or interactionally 'non-fatal' (Firth, 1996: 243). In line 25 PAN, after the communication obstacle generated by the word "petardos" (translated by LAI into "highlights"), responds with a validating token, without a "candidate completion' or an 'other-repair' providing the right word (presumably, "fireworks") or an explanation. Instead, he 'lets' the unsolved word search 'pass' as he can presumably figure out what the Catalan students are referring to thanks to both the plurilingual and multimodal resources deployed. Far from underscoring the obstacle, PAN corroborates his understanding in line 27 after LAI's attempt to describe the actual term multimodally (using an onomatopoeia and gestures). Similarly, in lines 3, 8, 12 and 14, we can confirm PAN's preference for progressivity (letting it pass) and interactional order (also essential for the development of the ATS) when he expands NER and LAI's initiated topic without probably having clearly understood what they refer to. 
Finally, going back to excerpt 1, we see PAN deploying another resource to 'normalise' the previous turn and thus let the appearance of interactional order prevail, hoping that the misunderstanding with the word "Athens" (excerpt 1, line 12) will unfold as the talk progresses. He does so by including the word "Athens" (not "Asthens", as NER has said in the previous turn) and by providing further information on the city (line 14), possibly expecting NER and LAI to finally recognise it. PAN 'lets' the obstacle 'pass' because he does not other-repair NER when she utters "Asthens", but he does not take a passive role as he actively, though implicitly ('normalising' it), attempts to clarify the term in favour of understanding.

\section{Conclusions}

Our analysis describes how learners, when exposed to English-as-lingua-franca (ELF) peer interactions in transnational educational settings, organise their participation following the rules of any ordinary interaction (Social Participation Structure, SPS) and at the same time orient themselves to task completion (Academic Task Structure, ATS), which entails full deployment of different interactive resources in favour of progressivity. The excerpts analysed here show how participation develops in terms of turn-taking and topic-management. As presented in the analysis, in excerpt 1 participants seem to initially find it hard to hold on a topic and to manage their participation fluently. However, in excerpt 2 (approximately two minutes later), it is significant to note how learners finally seem to engage in a more productive dynamics as they are able to focus on one topic and organise their participation in a more effective manner. The analysis reveals that the convoluted participant organisation in excerpt 1 could be a result of the learners' interpretation of the ATS as a 'competition' to demonstrate which country has the nicest places or the most alluring culture and lifestyle. This produces a sequence characterised by fast turn distribution with short turns and little (or no) turn allocation together with some misalignment among the participants. However, the change in the dynamics of the interaction, after they find a common ground topic (observed in excerpt 2), contributes to the production of longer turns and more turn allocation. This favours learners' deployment of both plurilingual ('let it pass' and 'make it normal') and multimodal resources in favour of intersubjectivity among participants and progressivity of both the task and the interaction. The analysis also gives some insights on the progression from plurilingual to unilingual mode of interaction which learners orient to. Although this is not a longitudinal analysis and we do not aim to track development, we can identify some of the actual stages of this progression when observing how learners, when faced with some communicative obstacles, display diverse resources (wordto-word translation, gestures, sounds, etc.) and, eventually, orient themselves towards the exclusive use of the target language (with a thorough description of the unclear concepts). 
While it is not the aim of this study to demonstrate learners take bigger risks when interacting with peers, the data seem to suggest that they put different plurilingual resources into play, along with other interactive mechanisms in favour of mutual understanding, alignment (intersubjectivity) and task completion, which does have an impact on their Interactional Competence (IC) deployment. Presenting learners with spaces to engage in transnational peer interactions can enhance their engagement to use English and can provide them with opportunities to participate in plurilingual interactions and thus to display (and possibly eventually develop) their IC.

\section{Acknowledgements}

The data presented here were collected within the research project 'Teachers as agents of transformation through their engagement in cross disciplinary innovative projects in the English classrooms (DATE)' sponsored by RecerCaixa 2016 (Project Ref.: 2016ACUP-001 (2017-2020)- LCF/PR/RC16/10100003). Principal investigator: Dolors Masats.

\section{References}

Auer, P. (1984). Bilingual conversation. Amsterdam: John Benjamins.

Auer, P. (1999). From code-switching via language mixing to fused Lects: Toward a dynamic typology of bilingual speech. International Journal of Bilingualism, 3(4):309-332.

Bachman, L. F. (1990). Fundamental considerations in language testing. Oxford: Oxford University Press.

Balaman, U., \& Sert, O. (2017). Local contingencies in L2 tasks: A comparison of context-sensitive interactional achievements across two different task types. Bellaterra Journal of Teaching \& Learning Language \& Literature, 10(3), 9-27. http://doi.org/ $10.5565 / \mathrm{rev} / \mathrm{jt} 13.746$.

Ballena, C., Masats, D., \& Unamuno, V. (2020). The transformation of language practices: Notes from the Wichi community of Los Lotes (Chaco, Argentina). In E. Moore, J. Bradley, \& J. Simpson (Coords.), Translanguaging as transformation: The collaborative construction of new linguistic realities (pp. 81-97). Bristol: Multilingual Matters.

Borràs, E., Moore, E., \& Nussbaum, L. (2015). Comment les étudiants montrent leurs connaissances dans des interactions internationales. In X. Gradoux, J. Jacquin, \& G. Merminod (Dir.), Agir dans la diversité (pp. 171-190). Paris: De Boeck.

Canale, M., \& Swain, M. (1980). Theoretical bases of communicative approaches to second language teaching and testing. Applied Linguistics, 1(1), 1-47.

Chomsky, N. (1965). Aspects of the theory of syntax. Cambridge, MA: MIT Press.

Donato, R. (1994). Collective scaffolding in second language learning. In J. P. Lantolf \& G. Appel (Eds.), Vygotskian approaches to second language Research. New York: Ablex.

Dooly, M., \& Sadler, R. (2019). Preparing English student-teachers with digital and collaborative knowledge: An illustrative synopsis. In D. Masats, M. Mont, \& N. GonzalezAcevedo (Eds.), Joint efforts for innovation: Working together to improve foreign language teaching in the 21st century (pp. 21-28). Rothersthorpe: Paragon Publishing. https:// doi.org/10.5281/zenodo.3064130. 
Erickson, F. (1982). Classroom discourse as improvisation: Relationships between academic tasks and structure and social participation structure in lessons. In L. C. Wilkinson (Ed.), Communicating in the classroom (pp. 153-181). Cambridge, MA:Academic Press.

Firth,A. (1996). The discursive accomplishment of normality: On 'lingua franca' English and conversation analysis. Journal of Pragmatics, 26, 237-259.

Goodwin, C. (2000). Action and embodiment within situated human interaction. Journal of Pragmatics, 32, 1489-1522.

Hall.J. K., \& Pekarek Doehler, S. (2011). L2 interactional competence and development. In J. K. Hall, J. Hellerman, \& S. Pekarek-Doehler (Eds.), L2 interactional competence and develepment (pp. 1-15). Bristol: Multilingual Matters.

Hall, J. K., Cheng, A., \& Carlson M. (2006). Reconceptualizing multicompetence as a theory of language knowledge. Applied Linguistics, 27(2): 220-240. https://doi.org/ 10.1093/applin/aml013.

Hall, J. K., Hellerman, J., \& Pekarek-Doehler, S. (Eds.). (2011). L2 interactional competence and development. Bristol: Multilingual Matters.

He, A.W., \& Young, R. (1998). Language proficiency interviews: A discourse approach. In R.Young \& A.W. He (Eds.), Talking and testing: Discourse approaches to the assessment of oral proficiency (pp.1-24). Amsterdam: John Benjamins.

Heritage, J. (1984). Garfinkel and ethnomethodology. Cambridge: Polity Press.

Heritage, J. (2007). Intersubjectivity and progressivity in person (and place) reference. In N. J. Enfield \& S. Levinson (Eds.), Person reference in interaction: Linguistic, cultural, and social perspectives (pp. 255-280). Cambridge: Cambridge University Press.

Hymes, D. (1972). Models of interaction of language and social life. In J. J. Gumperz \& D. Hymes (Eds.), Directions in sociolinguistics: The ethnography of communication (pp. 35-71). New York: Holt, Rinehart and Winston Inc.

Kramsch, C. (1986). From language proficiency to interactional competence. The Modern Language Journal, 70(4), 366-372.

Lerner, G. H. (2003). Selecting next speaker: The context-sensitive operation of a context-free organization. Language in Society, 32, 177-201.

Leyva, X., \& Speed, S. (2008). Hacia la investigación descolonizada: Nuestra experiencia de co-labor. In X. Leyva, A. Burguete \& S. Speed (Eds.), Gobernar (en) la diversidad: Experiencias indígenas desde América Latina. Hacia la investigación de co-labor (pp. 4-59). Mexico: CIESAS, FLACSO Ecuador \& FLACSO Guatemala.

Llompart, J., Masats, D., Moore, E., \& Nussbaum, L. (2019). 'Mézclalo un poquito': Plurilingual practices in multilingual educational milieus. Journal of Bilingual Education and Bilingualism, 23(1), 98-112. DOI: 10.1080/13670050.2019.1598934.

Llompart-Esbert, J., \& Nussbaum, L. (2018). Doing plurilingualism at school: keys concepts and perspectives. In S. Melo-Pfeifer \& C. Helmchen (Eds.), Plurilingual literacy practices. Bern: Peter Lang.

Lüdi, G., \& Py, B. (1986 [2002]). Etre bilingue. Bern: Peter Lang.

Lüdi, G., \& Py, B. (2009). To be or not to be ... a plurilingual speaker. International Journal of Multilingualism, 6: 154-167.

Markaki,V., Merlino, S., Mondada,L. Oloff, F., \& Traverso,V. (2013). Multilingual practices in professional settings: Keeping the delicate balance between progressivity and intersubjectivity. In A. C. Berthoud, F. Grin, \& G. Lüdi (Eds.), Exploring the dynamics of multilingualism: The DYLAN project (pp. 3-32). Amsterdam: John Benjamins. 
Masats, D. (2008). El discurs dels aprenents d'anglès com a llengua estrangera: Una aproximació interactivista al procés de construcció de tasques comunicatives. (Unpublished $\mathrm{PhD}$ thesis). Universitat Autònoma de Barcelona, Bellaterra.

Masats, D., Dooly, M., Juanhuix, M., Moore, E., \&Vallejo, C. (in press). Treballem junt(e)s per innovar: Col-laboració entre professorat i investigador(e)s en entorns plurilingües / Working together to innovate: Collaboration between teachers and researchers in plurilingual contexts. In D. Masats \& C. Pratginestós (Eds.), L'aula com a àmbit d'investigació sobre l'ensenyament i l'aprenentatge de la llengua / El aula como ámbito de investigación sobre la enseñanza y el aprendizaje de la lengua / A aula como contexto de investigação sobre o ensino e a aprendizagem de língua / The classroom as a site for research on language teaching and learning. Bern: Peter Lang.

Masats, D., Nussbaum, L., \& Unamuno, V. (2007). When the activity shapes the repertoire of second language learners. In L. Roberts, A. Gürel, S. Tatar, \& L. Marti (Eds.), EUROSLA Yearbook: Volume 7 (pp.121-147). Amsterdam: John Benjamins.

Nussbaum, L. (2017). Doing research with teachers. In E. Moore \& M. Dooly (Eds.), Qualitative approaches to research on plurilingual education / Enfocaments qualitatius per a la recerca en educació plurilingüe / Enfoques cualitativos para la investigación en educación plurilingüe (pp. 46-67). Research-publishing.net. https://doi.org/10.14705/rpnet.2017. emmd2016.621.

Nussbaum, L., \& Unamuno, V. (2000). Fluidité et complexité dans la construction du discours entre apprenants de langues étrangères. Acquisition et Interaction en Langue Étrangère, 12, 27-49.

Sacks, H., Schegloff, E. A., \& Jefferson, G. (1974). A simplest systematics for the organisation of turn-taking in conversation. Language, 50, 696-735.

Schegloff, E. A. (2006). Interaction: the infrastructure for social institutions, the natural ecological niche for language, and the arena in which culture is enacted. In N. J. Enfield \& S. C. Levinson (Eds.), Roots of human sociality: culture, cognition, and interaction (pp. 70-96). Oxford: Berg Publishers.

Seedhouse, P. (2005). The interactional architecture of the language classroom. Hoboken, NJ: Blackwell Publishing.

Walsh, S. (2011). Exploring classroom discourse: Language in action. London: Routledge.

Young, R.F. (2008). Language and interaction: An advanced resource book. London: Routledge.

Young, R. F. (2011). Interactional competence in language learning, teaching and testing. In R.F.Young (Ed.), Handbook of research in second language teaching (pp. 426443). London: Routledge. 


\title{
"Let's talk about el catalan's :-" \\ Student teachers' use of plurilingual and plurimodal resources in WhatsApp interaction
}

\author{
Melinda Dooly and Anna Czura
}

\section{Introduction}

In their definition of Virtual Exchange (VE), O'Dowd and Dooly (2020) point out that although "this technology-enhanced collaborative approach to teaching and learning languages has had several names over its (relatively) short history, each of them with their own particular connotations" (262), "they all highlight both the medium (virtual, online, digital, distance, global, networked) and the underlying purpose (exchange, intercultural, collaboration, learning)" (ibid.). The authors underscore a distinctive feature of VE, that is

the notion of sustained interaction (vs. short-term contact) involving a complex integration of collaborative work that promotes learning [and] that the exchange is somehow integrated into students' formal learning, including, for example, guided reflection on the exchange during class time and the recognition of academic credit for their work.

The growing research on VE in teacher education focuses on the goal of raising the participants' awareness of the usefulness of VE programmes and equipping them with pedagogical skills necessary to design and run such exchanges (Dooly, 2009; Dooly and Sadler, 2020). Despite the increase in such studies, there is a shortage of research exploring the use of plurilingual and plurimodal resources in the co-construction of meaning in the course of international dialogic interaction that takes place in VE. This chapter aims to fill this gap by applying Conversation Analysis (CA) to explore WhatsApp interaction between three student teachers from universities in the US and Catalonia. In particular, we attend to the impact of plurilingual and plurimodal codeswitching (Auer, 1988) on the sequentiality of the interaction. Researchers have previously argued that emoji may have more communicative purposes than simply conveying emotions or pictorially representing facial expressions or gestures (Kelly and Watts, 2015). Extending from these authors' work, it is suggested that emojis may be deployed to orchestrate the interaction (e.g. 
mitigation through humour) or to elicit a next-turn interaction from other participants (e.g. orientation of an expected response). With this brief study, we aim to contribute to Meredith's call for deeper understanding of how "technology impacts upon interactional practices" (2019: 254); in this case during a $\mathrm{VE}$ in a foreign language (FL) teacher education course.

\section{Methodological framework}

The data come from screen grabs that were voluntarily submitted by three preservice teachers who had been asked to meet in an online chat to discuss the task design and assessment of a project-based activity during a semesterlong VE. Their tasks would then be implemented in their internship schools. Two of the student teachers (Linda and Katherine) are MA students in a FL teaching programme at an American university. The other student teacher (Jaume) is enrolled in a BA degree in a university in Catalonia to become a FL teacher (English) in primary education. The names of the participants have been changed to protect their identity. All participants gave written consent to use their data for research purposes before carrying out the VE.

According to Gumperz (1977: 1), conversational code-switching can be defined as the "juxtaposition of passages of speech belonging to different grammatical systems or subsystems, within the same exchange". In this chapter we approach code-switching from two perspectives and set out to explore the communicative role of plurilingual and plurimodal resources, such as emojis, laughter tokens and punctuation symbols. In this study, we argue that emoji characters "might posit word-like properties and show grammatical patterns and orders, similar to words" (Stamatov, 2017: 2). Building on Jackendoff and Wittenberg's (2014) hierarchy of grammatical complexity for sentence-level utterances, Stamatov (2017) further argues that emojis can be "regarded as a new form of a visual language" and that this is increasingly accepted by "researchers and journalists alike" (9). In his study, in which participants (all experienced emoji users) were asked to communicate through emoji characters in isolation, Stamatov (2017) found that the participants used combinations of emoji that included features of "linear grammar and morphologically limited combinatorial structures" such as "placing the agent (or doer) before the patient or object of that action"; proposing that this is a recurring pattern seen in "other instances of communication, such as gesture-based communication" (Stamatov, 2017: 13).

The author also found that there were "sequencing patterns of emoji when people were asked to communicate without words" (Stamatov, 2017: 34) and "that people do use emoji patterning that resembles patterns found in other communication systems" (34), concluding "that emoji possess grammar, [although] a very simplistic one" (41). Following on this argument, emoji are understood here as an alternate code or language variant (albeit not a full-fledged language) and is an additional modality within the participants' repertoire. Moreover, in 
line with McSweeney's (2018) observation that the use of emojis requires a conscientious change between keyboards, we argue that this shift is an intentional action by the participant, further supporting our argument that the use of emoji is a deliberate code-switch, carried out with interactional intent.

Additionally, a micro-analytical perspective of code-switching views code alternation as a mutually organised event within the contextually delineated interaction. As Auer indicates, "variation in the repertoire has to be dealt with in a way that is sensitive to the general social and linguistic situation of the "community"' (ibid.). The members in this dataset belong to a virtual community of future teachers (Dooly, 2011); that is, a group of digitally competent individuals with mutual interests of completing an assigned group task (Dooly and Tudini, 2016). While the WhatsApp chat takes place outside the classroom, it is a requisite of the course and therefore it can be considered as an extension of institutional talk (ibid.).

\section{Analysis and discussion}

In excerpt 1 , the beginning of the session starts with a greeting adjacency pair, of which both the first and second part end with an extra-sentential codeswitch into emoji (lines 1 and 2). Jaume begins his turn with a rather effusive textual message ("Hi darling", complemented by three exclamation marks, line 1) and then code-switches to emoji with another rather lavish emoji (smiling face with heart eyes).

Excerpt 1. Hi darling!!! Participants: One Catalan student teacher, Jaume (JAU), and two American student teachers, Linda (LIN) and Katherine (KAT)

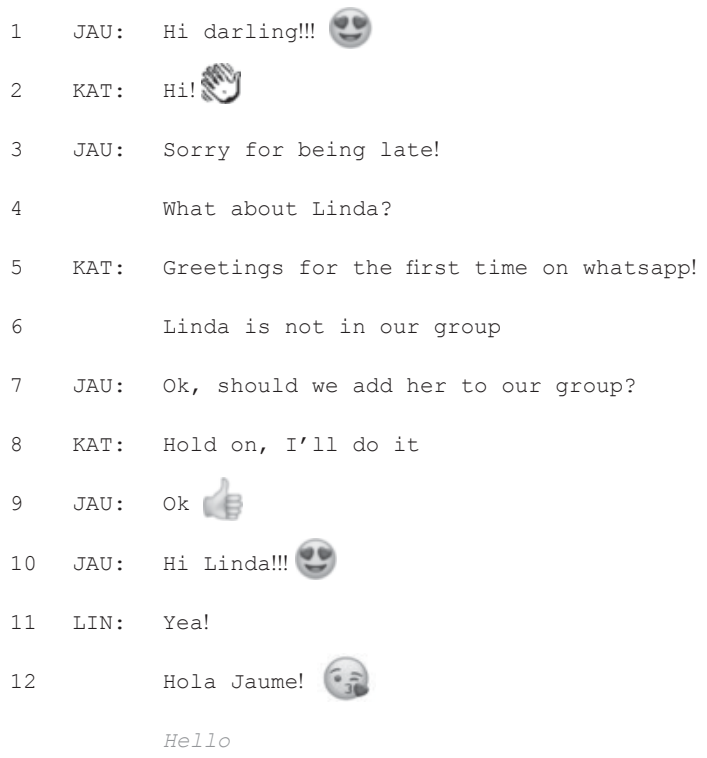




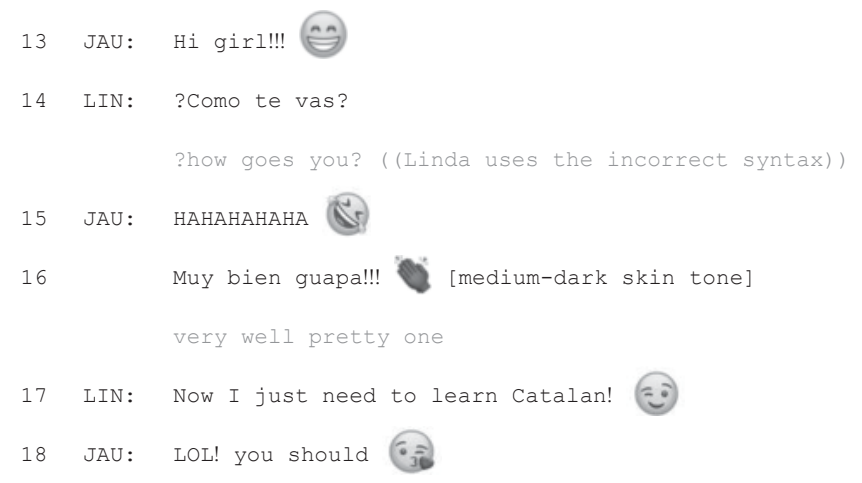

In his first turn, Jaume initiates the code-switch that Katherine aligns to, demonstrating, through her own use of emoji, her interpersonal affiliation to Jaume's affective stance. The next adjacency pair, which includes an expansion by Katherine, contains a new emoji (smiling face, line 5), which orients to the previous two uses of this code, further demonstrating the empathetic communication between the co-participants.

In line 4, Jaume begins to manage the institutional task, requesting information about the presence of the third participant in the group, Linda. Jaume responds to Katherine's offer to add Linda to the WhatsApp group with a preferred response "ok" (line 9) and then code-switches to add a thumbs up emoji to accentuate his alignment with her orchestration of the online events.

In line 11, Linda joins the group. Her first turn includes interesting shifts that involve three codes: she begins her turn in English, then continues her turn in Spanish (or Catalan), followed by a third shift into emoji (lines 11 and 12). Despite Linda's use of Jaume's L1s in line 12, in line 13, Jaume completes the Turn Construction Unit (TCU) in what might be considered the 'institutional' language (English). In his switch back to English, Jaume appears to be orienting to the institutional task and goal (Drew and Heritage, 1992), which is to discuss their projects in their target teaching language. However, Linda responds in line 14 with a code-switch to Spanish, although her syntax is incorrect. At this point, Jaume does align with Linda's more 'playful' role of experimenting with another language by responding with laughter in two codes (textual and emoji, line 15). Arguably, these two codes for laughter (textual and emoji) convey deep laughter, not merely chuckling or giggling, as communicated through the use of repetition and capital letters, followed by a more emotionally-charged emoji of rolling on the floor laughing. They also seem to reinforce one another (as verbal and gestural communication often merge).

Jaume then provides another sign of affiliation to Linda's code-switch to Spanish as he delivers an affective response in line 16. Despite the fact that timing in text chats are difficult to calculate (due to overlap in text writing which is not visible in the screen grabs), Jaume's response seems to fit the 
accounting that "agreements, confirmations and acceptances [...] generally are performed with no delays" (Pomerantz and Heritage, 2013: 214). Moreover, Jaume's affiliative response is extended with an emoji, which can be interpreted as his appreciation and encouragement for Linda's (somewhat bungled) attempt to use his L1. This code-switch is interesting in the way in which Jaume has changed the skin tone of the emoji, displaying a proficiency in the code that the others do not demonstrate as they tend to use the default skin tone of the emoji throughout the exchange.

The next two turns show continuance of this affiliation between the coparticipants as Linda declares that she should now try to learn Jaume's second language, Catalan, to which Jaume, once more, provides a two-code response, including the use of an emoji (line 18) as an embodiment of his agreement and appreciation.

In excerpt 2, Katherine provides a topical bid to bring the attention of the group back to the institutional task (line 19), followed by an embodied grimace, delivered through an emoji. Katherine's opening bid is not a direct request to move on-task; instead it is mitigated, not only by asking the status of the other participants' regarding their outside-of-class tasks but also through the use of the emoji. The use of the grimace can also be seen as a pre-empt of her co-participants' potential reluctance to begin the task. Up to this point in the exchange, the co-participants have been more oriented to more interpersonal aspects and Katherine seems aware that she is shifting topic to something less pleasant as she begins her turn with a token initiation device of "so" (line 19) and ends her turn with the emoji.

Excerpt 2. So how are you doing with the project? $\%$ Participants: One Catalan student teacher, Jaume (JAU), and two American student teachers, Linda (LIN) and Katherine (KAT)

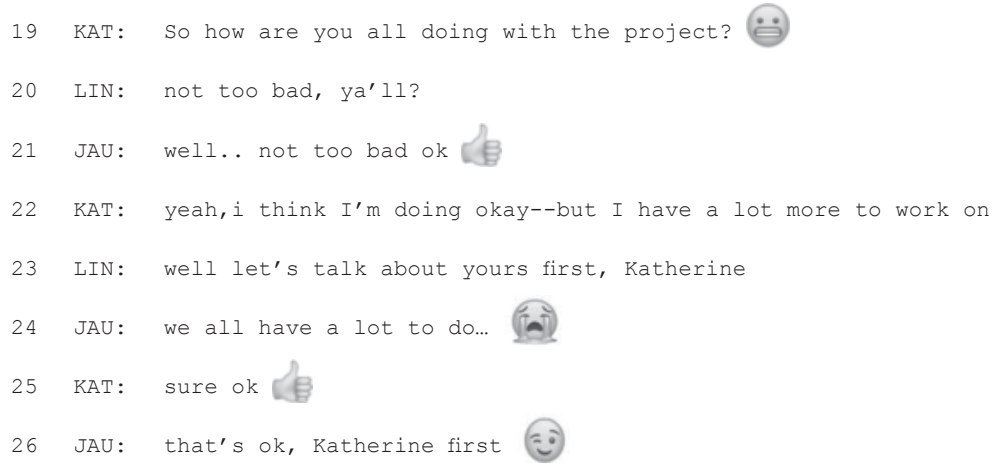

The co-participants commiserate on the little progress and amount of work they are dealing with (lines 21-22) through the use of code-switches between 
the textual code (monolingually in English) and emojis and then, in line 23, Linda shifts the focus directly to the task at hand with an explicit suggestion. In this turn, Linda's prefacing of her suggestion ("well") indicates that she is aware of her accountability for a topic shift to a less pleasant one but interestingly, she does not make use of the possibility of using a shift to emoji to mitigate her rather direct suggestion, which is almost instructional (e.g. 'teacher talk') and not common among equal peers.

In the analysed interaction, emojis are used frequently with the aim to represent an affective stance and interpersonal affiliation, and to convey specific communicative intent (e.g. a joke, exasperation or playfulness). However, the use of plurimodal resources is far from being that straightforward. Here, Linda chooses not to close a turn with an emoji that would mitigate her dissatisfaction with a sudden topic shift imposed by the third interactant. Consequently, a deliberate absence of an emoji in an interaction otherwise abounding with code-switching that include graphical icons also seems to carry a pragmatic value, aiming to communicate participants' emotional attitudes.

In line 24, presumably due to a semi-synchronous mode of Whatsapp interaction, Jaume's turn is not a direct response to Linda's instruction, instead he continues bemoaning his unfinished workload, using code-switches between text and emoji. Nonetheless, in line 25, Katherine does align to Linda's suggestion and immediately afterwards, in line 26, Jaume also orients to Linda's suggestion although the text and shift to an emoji can be interpreted more as a reluctant acquiescence.

The co-participants then dedicate several turns to work through the project (not included in this chapter for sake of brevity). Then in excerpt 3, line 116, Katherine apologises for the amount of time the co-participants have spent discussing her project and expresses her gratitude for their contributions and ideas for improving her project. Katherine enacts her apology and gratitude through embodied code-switching: (Emoji: Face with hand over mouth) and (Emoji: grinning face).

Both Jaume and Katherine accept and mitigate her apology by indicating that the interaction has been profitable for them (lines 118 and 119). Katherine then (line 121) provides another sequence-initiating action, similar to the one she had offered in excerpt 2. Her formulation is designed to elicit a preferred affirmative response. Jaume immediately agrees using both text and an emoji. Katherine maintains the negotiations and orchestration of the interaction to accomplish the task with another open-ended question: "Anyone of you?" (line 123) to which Linda suggests they talk about Jaume's project. She does so by making reference to an identity that she presumes he might have, calling him 'the Catalan', followed by a code-switch to a winking face (line 124). Jaume acknowledges the attributed identity although perhaps somewhat ambiguously (use of non-capital text laughter and an emoji, line 125). 
Excerpt 3. Let's talk about el catalan's. Participants: One Catalan student teacher, Jaume (JAU), and two American student teachers, Linda (LIN) and Katherine (KAT)

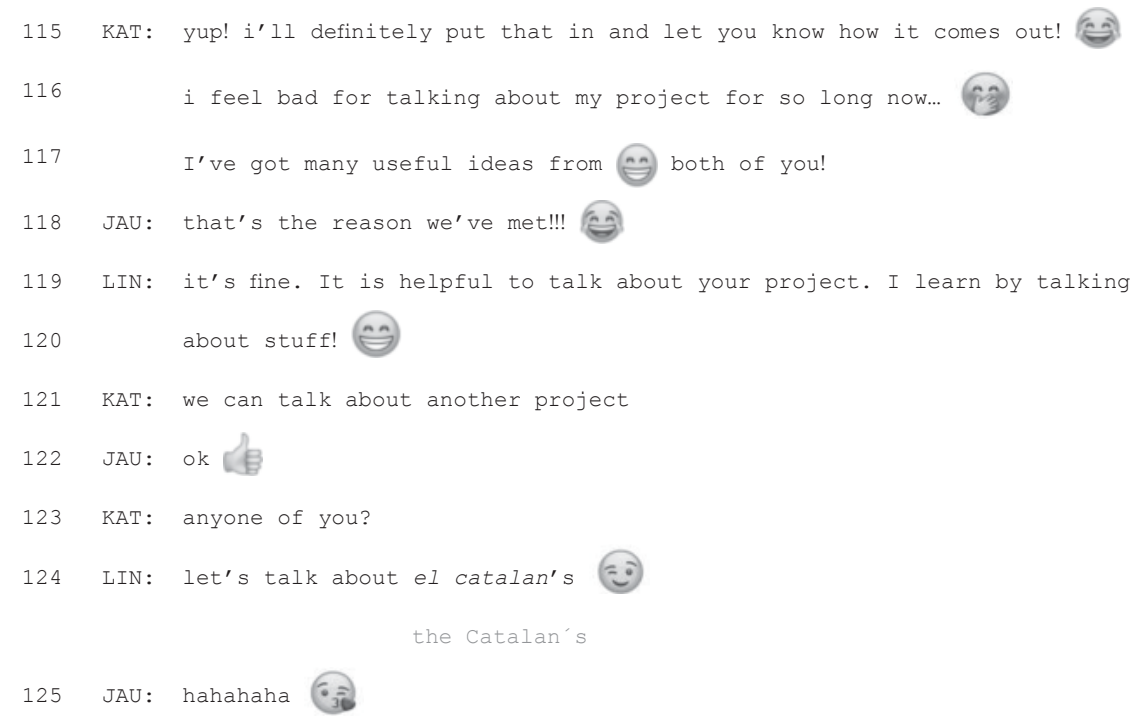

Given that laughter as a response to her statement can be seen as disaffiliative, Linda seems to be unsure of whether she has correctly attributed a Catalan identity to Jaume. The absence of other visual contextualisation cues characteristic of face-to-face communication may have caused a mismatch between the intended meaning of an emoji and the way it is understood by the receiver. Uncertain of the meaning of Jaume's use of multimodal resources, Linda asks for reassurance, mitigating her previous statement with "I don't want to assume", and code-switches to an emoji (line 127, excerpt 4).

Still, Jaume does not give her a direct answer; instead he corrects her spelling of the word, in capital letters. However, since capital letters in text chat is often understood as shouting, Jaume quickly demonstrates his positive orientation to Linda's identity attribution through the use of an emoji of clapping hands with special skin tone, which requires extra work in the code-switch (line 128). The interaction then moves to an expanded explanation of Linda's interest, accomplished through a second-person storytelling (Lucius-Hoene and Deppermann, 2000) of a friend of hers who identifies herself as a "Catalan independentist" (line 129), during which there is explicit uptake of Jaume's previous error correction (lines 131-132). Linda's explanation also helps her represent herself as an accountable party in the interaction by making explicit her interest and reason for asking somewhat personal questions. 
Excerpt 4. Are you catalan by the way? Participants: One Catalan student teacher, Jaume (JAU), and two American student teachers, Linda (LIN) and Katherine (KAT)

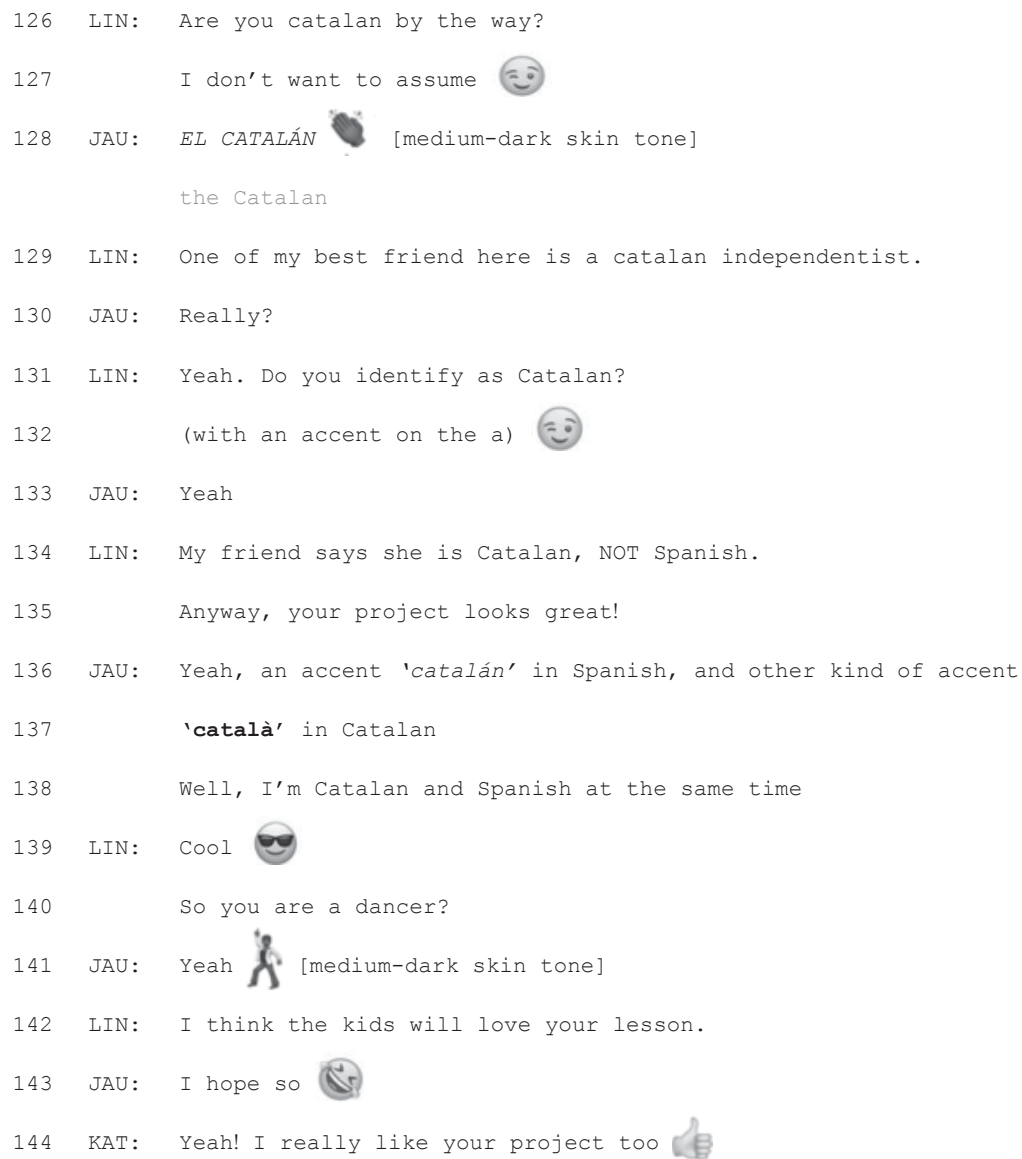

Jaume's rather short answer to her personal questions (line 133) prompts Linda to give an explanatory summary of her friend's identity (line 134), although she then quickly orients back to the institutional goal of discussing their projects, initiated with a token "anyway" to indicate change of topic. Jaume, however, does not accept the topic bid right away and continues on the topic of Catalan and Spanish identity while using the exchange to 'teach' the proper spelling of the two adjectives. In line 139 Linda seems to distance herself from what could conceivably become a political discussion with a short answer in English and emoji, then asks another question about his identity (line 140) but which is related to the institutional task, as we can see by Linda's post-TCU expansion (line 142). Only after the orientation of the topic has returned to the 
institutional task does Katherine join the exchange again (line 144), after a significantly long time of being a 'silent participant'. She rejoins the interaction by demonstrating her enthusiasm for Jaume's project, displayed through the use of exclamation mark and emoji.

These short plurilingual exchanges can be seen as examples of "presenting a friendly face" in an international setting (Nussbaum and Cots, 2011: 239; Moore, 2011). The small talk is used by two participants not only "to move between personal and professional identities to achieve their institutional goal" (Dooly and Tudini, 2016: 51), but also as a springboard for an intercultural inquiry about the participants' cultural and linguistic identity. The few studies that set out to explore plurilingual practices in online communication revealed that code-switching may serve, for instance, to clarify the meaning, separate facts from personal viewpoints, negotiate the functioning of an online community and establish interpersonal relationships (Androutsopoulos, 2013). The use of languages other than the institutional language (English) in the analysed interaction falls into the last category, as some rather basic, and occasionally incorrect, Spanish and Catalan expressions were used to exchange greetings and to mark a transition between tasks.

In this particular case, plurilingual code-switching is indicative of task orientation - the American student who initiates plurilingual exchanges treats this international interaction as an opportunity to expand her intercultural understanding, whereas the remaining two participants either adopt a responsive position, in alignment with the code-switching between language and emoji as is the case of Jaume, or choose to focus principally on the institutional task, as displayed by Katherine, who code-switches with emojis far less than the other two participants.

Throughout the interaction Jaume's embodiment through emoji allows him to represent himself as a proficient and effusive user of multimodal resources. In comparison with the other two interactants, Jaume displays a distinctive communicative style both in terms of the quantity and the choice of graphic icons, which include emotionally-loaded emojis, laugher tokens, exclamation marks and sophisticated skin-tone emoji, perhaps to highlight his identity and cultural distinctiveness. His communication style stands in a stark contrast to previous research findings in the Spanish context, which indicate that women use emojis more profusely, whereas men tend to go straight to the point and do not engage in 'unnecessary' greetings (Pérez-Sabater, 2019). Jaume's elaborate code-switching may be rooted in being the only non-native speaker in this conversation. In studies on plurilinguals' code-switching for expressing emotion, it has been argued that plurilingual individuals may feel "significantly less logical, less serious, less emotional and increasingly fake when using their L2, L3 and L4 compared to their L1" (Dewaele, 2016: 473). Given that English is not Jaume's L1, perhaps his embellished greetings, including codeswitches to rather ornate emoji, helps him demonstrate an affective status to 
his co-participants. However, this study is based on one conversation and future research is necessary to explore whether plurimodal code-switching is culture or context dependent, or whether it stems from individual predispositions towards a particular communication style.

\section{Conclusions}

This small study illustrates that resorting to other speakers' use of resources may be a useful tool for initiating polite small talk preliminary to on-task work (Dooly and Tudini, 2016), forging interpersonal relations and encouraging an intercultural enquiry that goes hand in hand with the completion of an institutional task in VE. By considering the use of emoji as an additional code, we have demonstrated that the student teachers taking part in the VE and are able to manage and orchestrate the online interaction, making use of all the plurilingual and plurimodal resources at hand. As can be seen in this chapter, meaning making in technology-mediated interaction goes beyond the use of linguistic resources and depends on users' familiarity with different genres, texttypes and semiotic resources, which help to overcome the absence of visual channels, social context cues (e.g. facial expressions, gestures, nodding) and prosodic features that occur in a natural conversation.

In line with the 'experiential modelling approach' (Guichon and Hauck, 2011: 195), teachers are more likely to implement tools and pedagogical innovations they have experienced themselves as students. Given the more and more prominent role of technology-enhanced language learning scenarios, future teachers' awareness of the tools used in online interaction and the ability to engage in a digital intercultural dialogue may have far-reaching implications in their future teaching and assessment practices. It is important that interactions such as these, which involve future teachers, be analysed in detail in order to gain insight into the alignment (or gaps) between the tools, tasks and learning objectives in VE learning projects. Arguably, the teachers' practical knowledge of the properties and conventions of online interaction, including the use of plurilingual and plurimodal resources found in commonly used social media, may prove valuable in facilitating successful VE interactions, encouraging authentic language use and providing corrective feedback (cf. Moffitt, Padgett, and Grieve, 2020).

\section{Acknowledgements}

The authors would like to thank the participants in this study who so generously allowed their online interactions to be recorded and analysed. It is also recognised that funding for this study has come from European Union's Horizon 2020 research and innovation programme under grant agreement No 845783 (ASSESSnet). 


\section{References}

Androutsopoulos, J. (2013). Code-switching in computer-mediated communication. In S. C. Herring, D. Stein, \& T.Virtanen (Eds.), Handbook of the pragmatics of CMC (pp. 667-694). Berlin: Mouton de Gruyter.

Auer, J. C. P. (1988). A conversation analytic approach to code-switching and transfer. In M. Heller (Ed.), Codeswitching:Anthropological and sociolinguistic perspectives (pp. 187213). Berlin: Mouton de Gruyter.

Dewaele, J.-M. (2016). Multi-competence and emotion. In V. Cook \& L. Wei (Eds.), The Cambridge handbook of linguistic multi-competence (pp. 461-477). Cambridge: Cambridge University Press.

Dooly, M. (2009). New competencies in a new era? Examining the impact of a teacher training project. ReCALL, 21(3), 352-369.

Dooly, M. (2011). Crossing the intercultural borders into 3rd space culture(s):implications for teacher education in the twenty-first century. Language and Intercultural Communication, 11(4), 319-337.

Dooly, M., \& Sadler, R. (2020). "If you don't improve, what's the point?” Investigating the impact of a "flipped" online exchange in teacher education. ReCALL, 32(1), 424. DOI:10.1017/S0958344019000107.

Dooly, M., \& Tudini, V. (2016). 'Now we are teachers': The role of small talk in student language teachers' telecollaborative task development. Journal of Pragmatics, 102, 38-53.

Drew, P., \& Heritage, J. (Eds.) (1992). Talk at work: Interaction in institutional settings. Cambridge: Cambridge University Press.

Guichon, N., \& Hauck, M. (2011). Teacher education research in CALL and CMC: More in demand than ever. ReCALL, 23(3), 187-199.

Gumperz, J. (1977). The sociolinguistic significance of conversational code-switching. RELC Journal, 8(2), 1-34. doi: 10.1177/003368827700800201.

Jackendoff, R., \& Wittenberg, E. (2014). What you can say without syntax: A hierarchy of grammatical complexity. In F. J. Newmeyer \& L. B. Preston (Eds.), Measuring grammatical complexity (pp. 65-82). Oxford: Oxford University Press.

Kelly, R., \& Watts, L. (2015). Characterising the inventive appropriation of emoji as relationally meaningful in mediated close personal relationships. Experiences of Technology Appropriation: Unanticipated Users, Usage, Circumstances, and Design, 1-5. Opus: University of Bath Online Publication Store. Available at: http://opus.bath. ac.uk/46780/1/emoji_relational_value.pdf. Accessed 20 June 2020.

Lucius-Hoene, G., \& Deppermann, A. (2000). Narrative identity empiricized - A dialogical and positioning approach to autobiographical research interviews. Narrative Inquiry, 10(1), 199-222.

McSweeney, M. A. (2018). The pragmatics of text messaging. Making meaning in messages. New York/Abingdon: Routledge.

Meredith, J. (2019). Conversation analysis and online interaction. Research on Language and Social Interaction, 52(3), 241-256. DOI:10.1080/08351813.2019.1631040.

Moffitt, R. L., Padgett, C., \& Grieve, R. (2020). Accessibility and emotionality of online assessment feedback: Using emoticons to enhance student perceptions of marker competence and warmth. Computers \& Education, 143, 1-11. DOI:10.1016/ j.compedu.2019.103654.

Moore, E. (2011). Plurilingual practices at a Catalan university doing internationalisation: Context and learning. (Unpublished PhD thesis). Universitat Autònoma de Barcelona, Bellaterra. 
Nussbaum, L., \& Cots, J-M. (2011). Doing learning languages in a multilingual context: Pragmatic aspects of classroom discourse in Catalonia. In L. Payrató \& J.M. Cots (Eds.), The pragmatics of Catalan (pp. 331-359). London: De Gruyter.

O'Dowd, R., \& Dooly, M. (2020). Intercultural communicative competence through telecollaboration and virtual exchange. In J. Jackson (Ed.), The Routledge handbook of language and intercultural communication (2nd ed., pp.361-375). Milton Park: Routledge.

Pérez-Sabater, C. (2019). Emoticons in relational writing practices on WhatsApp: Some reflections on gender. In P. Bou-Franch \& P. Garcés-Conejos Blitvich (Eds.), Analyzing digital discourse: New insights and future directions (pp. 163-189). London: Palgrave Macmillan. DOI: 10.1007/978-3-319-92663-6_6.

Pomerantz, A., \& Heritage, J. (2013). Preference. In J. Sidnell \& T. Stivers (Eds.), The handbook of conversation analysis (pp. 210-228). Chichester: Jack Wiley \& Sons.

Stamatov, E.G. (2017). Do emoji use a grammar? Emergent structure in non-verbal digital communication. (Unpublished Master thesis). Tilburg School of Humanities, Tilburg University, Tilburg. Available at: http://arno.uvt.nl/show.cgi?fid=142877. Accessed 27 June 2020. 


\section{Index}

Note: Page numbers in italics indicate figures on the corresponding pages.

accommodation norm 29, 37; bilingual norm 29, 34, 36; ingroup norm 29, 34, 38 ; monolingual norm 29,36

action research $\mathrm{xv}, 18,111$; collaborative action research $\mathrm{xv}, 188,191$; participatory action-research 54

after-school activities / program 43-44, 46-47, 50, 162, 165

Álvarez-Caccamo, C. xix

attention 4, 67-69, 74-76, 78, 116, 118, $120,135,144-145,149$

Auer, P. xviii-xix, 29, 86, 202

automotive maintenance training $177-178,186$

awareness 3, 8, 28, 112, 149, 159,

160, 200, 209: language 27, 54;

metalinguistic 96

Balaman, U. 191

Bange, P. xviii

Bartlett, L. 46

Barwell, R. 66, 68, 79, 135

Blackledge, A. 4

Blom, J. P. xviii

Bonacina-Pugh, F. xv, 29

Borràs, E. 4, 17, 125, 189

boundary objects xv

Breen, M. 16

business English teaching see English for Specific Purposes (ESP)

Candelier, M. 96

car maintenance training see automotive maintenance training

Catalan Statute of Autonomy xiii

Cenoz, J. 4 classroom interaction xix, $\mathrm{xx}, 4,17-18$, 55-56, 67, 110, 124, 126, 132, 134

co-construction of context 86; of knowledge/content 15, 79; of meaning 124, 126, 131-132, 200; of practiced language policy 30 ; of talk-in-interaction 68 ; of turns 66, 78; of utterances 70

code-switching xvii-xix, 4, 29, 86, 92, 110 , 120, 136, 190, 195, 200-202, 205,

208-209; discourse related xviii, xix, 17, 29, 86; participant related xviii, 17, 29, $48,112,115$; see also contextualisation cues; language alternation

Common European Framework of Reference (CEFR) for Languages xiv, xviii, 28, 96, 123

competence: asymmetric 111, 120; brokering 48, 50; communicative xvi, 7 , 28, 186, 189; cultural 95, 96; discursive 177, 178, 186; interactional xvii, xx, 56, 149, 151, 188, 189, 197; intercultural 46; language 111, 120,164; language and literacy 45; linguistic 189; metalinguistic 27; plurilingual xiv, xvi, 3, 44, 45, 48, 51; plurilingual and pluricultural xvi, 95, 96, 100, 105; socially-situated xvi; sociolinguistic 95-96, 98, 101, 104

contextualisation cues xix, 29, 34, 85-86, 92, 206

Conversation Analysis xvii, xx, 15-18, 46, 55-57, 66-68, 109-110, 124, 126, 134-136, 150, 163, 191, 200; see also attention; intersubjectivity/progressivity, axis between; preferred language; progressivity/intersubjectivity, axis 
between; repair; sequence; sequentiality; turn taking

Cook, G. 4

Coste, D. xvi

Coulthard, M. 16, 23, 55

Creese, A. 4

Cromdal, J. xix, 17

Cummins, J. xix, 3, 10

Davison, C. 66

de Pietro, F. xvi

discursive competence see competence

Dooly, M. 123, 200

Duchêne, A. 177

Duranti, A. 163

Duverger, J. 69

emic perspective on analysis xix

emojis 200-209

English as medium of instruction (EMI) see immersion program

English for Specific Purposes (ESP) 3, $4-5,13$

English Medium Education in Multilingual University Settings (EMEMUS) see immersion program epistemic status 50, 56-57, 60-61, 64, 154

Erickson, F. 16, 190

Ethnography xv, xx, 44, 47, 50, 85, 136, 150, 162, 163, 172, 177, 179-180, 191; ethnographic research 47, 179; multi-sited ethnography 179; see also action research

Ethnomethodology xv, 18, 55, 134, 163; Membership Categorisation Analysis (MCD) xx, 97, 98, 110, 112, 163-164, $168,171,172$

Filliettaz, L. 177

Firth,A. 110, 190

footing 112; footing model 16

Gafaranga, J. 86

Gajo, L. 17, 18, 67, 135

García, O. 46

gaze see multimodality

gestures see multimodality

Goffman, E. 5, 16, 125, 163

Goodwin, C. xviii, 16, 125, 163, 178

Goodwin, M. H. xviii, 16, 125

Gorter, D. 4

Greiffenhagen, C. 17

Gumperz, J. xviii, xix, 29, 85, 164, 201
Hall, G. 4

Hall, J. K. 151

Hanson, W. 45

Heritage, J. 56

higher education 18, 123, 134: EMEMUS

123-124, 132-133; physical therapy

education/ training 124; science

education 134-137, 145; tertiary

education xiv, 15 ; university $\mathrm{xx}-\mathrm{xxi}, 3,5$,

13, 15-18, 23, 86, 109, 111, 120,

123-125, 132, 134-136, 201

Hutchby, I. 67

hybrid forms xvii, 36, 48, 69, 75-76, 110 , 116-117, 119-120, 123, 190

Hymes, D. xvi, 189

Identity xix-xx, 17, 29, 45, 50, 55, 57, 96$97,100,103,112,118,163-164,172$, 178, 189, 201, 205-208: construction, 55-56, 64; discursive identities 56; expert /non-expert identities 54; linguistic identities 87 ; situated identities 56; social identity 96 ; sociolinguistic identities 45,50

immersion program 66: Content and Language Integrated Learning (CLIL), 43, 109, 134, 135; English as a Medium of Instruction (EMI), 15, 17-19, 21, 23, 109-111, 120, 134; English Medium Education in Multilingual University Settings (EMEMUS) 123-124, 132-133

Initiation, Response, Evaluation (IRE) sequence see interactional sequence interactional competence see competence interactional sequence 16, 132, 137, 165: adjacency pairs 86, 154, 159, 202, 203; adjacency triads 67; IRE (Initiation, Response, Evaluation) 55; IRF (Initiation, Response, Feedback) 16, 23, 55, 63, 86; QAC (Question-AnswerComment) 55

interpersonal function of language 7-9 intersubjectivity 55-56, 116, 190, 193, 196-197; intersubjectivity/progressivity, axis between 110,120, 188, 195

Jackendoff, R. 201

Jacquemet, M. 164

Jefferson, G. xxi, 16, 18, 68, 111

Kasper, G. 56

Kerr, P. 4 
Kleifgen, J. 46

knowledge construction 15, 17, 110, 116, 132: academic knowledge 17-18, 23; discipline knowledge 4; professional knowledge 177, 185; technical knowledge 186; see also scaffolding; zone of proximal development (ZPD)

Kramsch, C. 189

Kunitz, S. xv, 85

language alternation 15, 17, 18, 19, 23-24, 29-30, 34, 36, 69, 85, 86-87, 89, 92; see also code switching; contextualisation cues; hybrid forms; plurilingualism; transidiomatic practices

language brokering 44-46, 51: brokers 45-46; cultural brokering 47-48, 50; plurilingual brokering competence 50

language policies: language policies in Catalonia xiii-xiv, 27, 96; language policies in Morocco 98; language policies at universities xiv, 15, 18; see also language policy

language policy $21,28-29,33,85,113$ : declared language policy 38 ; doing language policy 17; English-only 112; implicit 112; language policy documents 15,28 ; perceived language policy 37 ; practised language policy $23,29-30$, 33-34, 37-38; see also language policies

languages: Amazigh 98, 103; Aranese xiii; Catalan xiii-xiv, xv, xxii, 5-8, 10-13, 15, 17-18, 21-23, 28-34, 36-38, 47-50, 57, 66, 69, 75-78, 85, 87, 89-90, 92-93, 96-98, 101-104, 111-112, 115, 117, 140, 144, 152, 154, 156, 166, 180, 193, 203-204, 207-208; (Darija-Moroccan) Arabic xxii, 27, 30-37, 98, 100-104; English xiv, xxi, xxii, 3-7, 9-13, 15, 17-18, 21-23, 29, 47-50, 58-59, 69, 85-89, 93, 109, 111-112, 115, 117, 120, 123, 126-130, 132-137, 140, 143-145, 149-150, 152, 154, 157-159, 164-166, 168-169, 171-172, 185, 188, 191, 195-197, 201, 203, 205, 207-208; French xxii, 66, 69, 75-76, 78-79, 86, 98, 127, 129, 179-180; Fusha (Modern Standard Arabic), 98; Greek xxii, 194; Mandarin/ Chinese xxii, 165-166, 168, 170-172; Punjabi xxii, 47-48, 50; Riffian Berber xxii, 98, 101-104; Spanish xiii-xv, xxii, 5-7, 12-13, 18, 28-29, 33-34, 36-37,
47-48, 54, 57, 62-63, 69, 85-87, 89, 92-93, 97-104, 111-112, 114-115, 126, 138, 140-141, 143-144, 154, 156, 158, 165-166, 168-172, 179-80, 184-185, 193-195, 203, 207-208; Turkish, 115;

Urdu xxii, 54, 57, 59-63

Lave, J. xvii, 86, 96, 124, 132

learning theories: language socialisation $\mathrm{xv}$, xvii, 86; socio-constructivist perspective 18, 109-110, 124; sociocultural perspective xvii, 134-136; sociointeractional $\mathrm{xvi}, \mathrm{xx}, 44$; (socio-) interactionist perspective xvii

Lerner, G. 68

let it pass/make it normal 120,190, 196

Lindström, A. 124

Llompart, J. xvii, 46, 190

Lüdi, G. xvii, 87

make it normal/let it pass 119,120,190, 196

Markee, N. xv, 55, 85

Masats, D. 48, 67, 125, 128, 131-132

McHoul, A. 55, 68

McSweeney, M. A. 202

mediation xvi, 50, 135, 189: cultural 45 ; instrument of 18 ; mediation-ininteraction 134-135; re-mediation 18, 78; strategies 149; tool 191

medium: of (classroom) interaction 17, $21,23,33,34,37,69,79,87,90$; of communication xiii, 29, 34, 36; of instruction xiii, xix, xxi, 15, 17-18, 21, 23, 29, 66, 75, 85, 87, 103-104, 134; suspension 69,76 ; see also immersion program

Mehan, H. 16, 55

Meredith, J. 201

mode(s) 87, 93, 190, : plurilingual mode of communication 4, 15, 17, 24, 87, 101, 104, 112; unilingual mode of communication xvii, xviii, 17, 87, 190, 192-196

Mondada, L. xvii, xx, 18, 44, 179

Moore, D. xvi

Moore, E. 4, 45, 189

Morales, A. 45

Mori, J. 55

Moustaoui, A. 98, 103

Mülher, M. 17

multilingualism see plurilingualism multimodality xx, xxii, 110; multimodal complexity 46; multimodal conversation 
analysis 124,126 ; embodied resources 15, 132; gaze xviii, 16-17, 23, 37, 69, $125,128,131-132,135-136,168,170$; gestures xviii, 15-16, 19, 35, 50, 120, 125, 131, 156, 178, 185-186, 190, 195-196, 200, 209; multimodal interaction xxi; multimodal interactional features 165; manipulation of objects 125; manipulation of the body 131, 132; practices 129, 130, 177; procedures 188 ; repertoire xviii; resources xviii, $\mathrm{xx}, 15$, 17, 19, 23, 48, 50, 62, 117, 119-120, 132, 136, 145, 178, 186, 188, 193, 195-196, 206, 208; sequences xxi; texts 46

Musk, N. xix, 17

Noguerol, A. 69

Norton, B. 96

Nussbaum, L. xvii, 4, 44, 45, 48, 96, 98, 179 , 189, 190

O’Dowd, R. 200

participation: Academic Task Structure (ATS) 190, 192-193, 195-196; embodied participation frameworks xviii; format 17 , 21 ; frames $125,127,128,131$; framework xviii, 189; peripheral 124, 132; public 15, 19, 23; social 86; Social Participation Structure (SPS) 16, 190, 196; student 15, $21,23,55$; in translocal communicative tasks 177

Pawley, A. 7-8

peer interactions 188-189, 191, 196-197

Pekarek Doehler, S. xvii, xx, 18, 135 physical therapy training see higher education plurilingual and pluricultural competence see competence

plurilingualism xiv, 17, 43-46, 120, 136, 164: didactisation of 69,104 ; plurilingual practices xiv-xxii, 3, 5, 16-19, 27, 43, 89, 126, 190, 208; pluriliteracies xiv, 43-47; pluriliteracy 43,50

preferences in language use: preferred language xiv, 34, 37, 158; language of preference 34

primary education xiv, 46-47, 160, 201; classrooms 86; schools xxii, 30, 37, 46, 69, 87, 150; students 30, 46, 95, 98, 137, 151-159; teachers xx, xxi, 27, 87, 136, 151-159, 201 progressivity 113, 124, 159, 190, 192, 195-196; progressivity/intersubjectivity, axis between 110,120,188, 195

project based learning $6,57,63,98,150$, 165, 179, 188, 191, 201, 204-206, 208

Py, B. xvii, 87

regulation 92, 134-136; object-regulation 135; other-regulation 135 ; self-regulation $135-136$

repair $67-68,86,125,129,154,156-160$, 178-180, 189-191; hetero-repair 37, 129; (other-initiated) other-repair 66-67, 156, 158, 190, 195-196; repair itineraries 68; see repair sequences; self-repair 21, 49, 156, 158-159; trajectories of repair 70 repertoire: linguistic xx, 44, 54, 64, 104, 178, 185; multimodal xviii; plurilingual xx, xxii, 17, 28, 43-44, 50-51, 63, 95-96, 109, 116, 120

Richards, K. 56

Sacks, H. 16, 56, 68, 97, 163-164

scaffold, 37, 104, 120, 172, 190, 195; scaffolding xviii, xxii, 3-4, 11-12, 37, 69, 136, 189

Schegloff, E. A. 16, 68, 183

secondary education: secondary classrooms 86 ; secondary schools 87 ; secondary students 188, 191; secondary teachers 87,188

Second Language Acquisition (SLA) xvii, 110

Seedhouse, P. 16, 17, 55, 67, 136

semiotic systems xiv, xviii; (nonverbal) semiotic resources xix, 16, 23, 48, 6668, 109, 120, 124, 126, 151, 189, 209; semiotic repertoire 123,132

sequence $21,30,55,61,63,67,125-127$, 129, 131-132, 134, 137, 145, 156-157, 162, 165, 168, 172, 190-196; repair sequence $56,67-68,72,74-75,78-79$, 129, 136, 159; side /lateral sequence 48, 103, 138, 193

sequentiality $19,55-56,135,200$

Sert, O. 191

Sinclair, J. 16, 23, 55

sociolinguistic: dimensions xvii; dynamics xx; environment $85,87,92-93$; identity $\mathrm{xx}, 45,50$; information 103, 104; knowledge 97, 103; landscape xiii; patterns 86 ; policies 92 ; superdiversity 164 
sociolinguistic competence see competence Sorjonen, M. L. 124

Spolsky, B. 28-29

Stamatov, E. G. 201

Syder, F. 7-8

talk-in-interaction xiv, xvi-xix, xxi, 16, 19, $27,29,34,38,55-56,66,68,85,87$, 95-97, 101, 178

task-based learning 125: task-as-outcome 118-120; task-as-workplan 16, 23, 111; task-in-process 16, 120

teamwork practices 109; group work 12-13, 28, 30, 33, 37, 56-58, 62, 67, 69, 75, 95-97, 101, 104, 109, 113, 119-120, 137, 139-140, 143-144, 150, 154, 165, 168, 177-180, 185-186, 188-191, 193, 202-204; pair work 86, 125

telecollaboration see computer-mediated communication (CMC)

ten Have, P. 163

transcription 30, 69, 11, 126; symbols xxi, xxvi

transidiomatic practices $162,164,172$

translanguaging 4, 69, 136, 164

translocal: communal identity 178 ;

communicative task 177; community

178-180; interactions xxi; settings/spaces xviii, xx, xxii

transnational plurilingual interactions 188, 197; transnational exchange 188; transnational educational settings 196

Tse, L. 45

turn taking 55, 67, 188-189, 191, 196; turn construction unit (TCU) $68,75,78,149$, 154, 157-159, 203, 207
Unamuno,V. 45, 48, 86, 96, 98

university classrooms see higher education

Ustunel, E. 17

Vallejo, C. 45, 123

Veronesi, D. 17

videos, communication mediated through 165, 179-180, 185-186

Virtual Exchange (VE) 149, 200-201, 209; see also computer-mediated communication (CMC); WhatsApp interactions

vocational education 177, 179, 186; vocational schools / training centres xxii, 178-179, 186; vocational students 177,186

Wagner, J. 110

Wenger, E. xvii, 86, 96, 124, 132

WhatsApp interactions 200, 2005: codeswitching 201-203, 204-206; emojis 200-208; intercultural small talk 208-209

Williams, A. 66

Williams, C. 4, 69

Wittenberg, E. 201

Wooffitt, R. 67

Woolard, K. A. 29

Young, L. 17

Young, R. F. 189

Zarate, G. xvi

zone of proximal development (ZPD) 136

Zuengler, J. 55 